UNIVERSIDADE DE SÃO PAULO

FACULDADE DE ECONOMIA, ADMINISTRAÇÃO E CONTABILIDADE DEPARTAMENTO DE ADMINISTRAÇÃO

PROGRAMA DE PÓS-GRADUAÇÃO EM ADMINISTRAÇÃO

PROPAGAÇÃO E COMBATE À CRISE DE LIQUIDEZ BANCÁRIA:

O CASO DA MINICRISE DE LIQUIDEZ DE 2004

Carlos Ahmar

Orientador: Prof. Dr. Roy Martelanc 
Prof ${ }^{a} \operatorname{Dr}^{\mathrm{a}}$ Suely Vilela

Reitora da Universidade de São Paulo

Prof. Dr. Carlos Roberto Azzoni

Diretor da Faculdade de Economia, Administração e Contabilidade

Prof. Dr. Isak Kruglianskas

Chefe do Departamento de Administração

Prof. Dr. Lindolfo Galvão de Albuquerque

Coordenador do Programa de Finanças 


\section{CARLOS AHMAR}

\section{PROPAGAÇÃO E COMBATE À CRISE DE LIQUIDEZ BANCÁRIA: \\ O CASO DA MINICRISE DE LIQUIDEZ DE 2004}

Dissertação apresentada ao departamento de Administração da Faculdade de Economia, Administração e Contabilidade, como requisito para a obtenção do título de Mestre em Administração.

Orientador: Prof. Dr. Roy Martelanc. 
FICHA CATALOGRÁFICA

Elaborada pela Seção de Processamento Técnico do SBD/FEA/USP

Ahmar, Carlos

Propagação e combate à crise de liquidez bancária : o caso da minicrise de liquidez de 2004 / Carlos Ahmar. - São Paulo, 2006.

$131 \mathrm{p}$.

Dissertação (Mestrado) - Universidade de São Paulo, 2006

Bibliografia

1. Crise financeira 2. Sistema financeiro 3. Crise bancária 4.

Banco Central 5. Depósito compulsório I. Universidade de São Paulo.

Faculdade de Economia, Administração e Contabilidade II. Título.

CDD -336.9 
A Isabel e Mariana, por me ensinarem a razão da vida.

A Eliana, por me ensinar que a vida tem uma razão. 
Agradeço a meus pais pelo carinho e abnegação. Não só me ensinaram a andar mas mostraram que são infinitos os caminhos que se pode tomar.

Agradeço ao Prof. Dr. Roy Martelanc, pela cobrança incisiva e pela orientação acadêmica, tão importantes para que esse projeto seguisse adiante.

Agradeço ao Prof. Dr. José Roberto Securato e ao Prof. Dr. Almir Ferreira de Souza, pela confiança depositada e pelos ensinamentos.

Agradeço ao Prof. Dr. Wadico Waldir Bucchi e ao Dr. Caio Fonseca Ferreira pelos comentários, sugestões e críticas, que tanto acrescentaram ao trabalho.

Agradeço ao amigo Raul Cândido da Silva, pelo apoio e estímulo.

Agradeço a Dona Carmela e Seu Vicente, pela dedicação e amor às netas, que também são suas filhas.

Agradeço a Isabel e Mariana por entenderem as minhas ausências, pelo sorriso e, principalmente, por me proporcionarem a imensa alegria de ser pai delas.

Agradeço a Eliana pela nossa família, que é mais do que eu podia sonhar, pelas horas que teve de se afastar, pela compreensão, pela irritação, e por seu amor, que é tudo que um homem pode desejar. 
"Men, it has been well said, think in herds; it will be seen that they go mad in herds, while they only recover their senses slowly, and one by one."

Charles Mackay (1841) 


\section{RESUMO}

A intervenção no Banco Santos, em novembro de 2004, propiciou o surgimento de uma crise de liquidez em um segmento bem delimitado do mercado bancário brasileiro.

O presente estudo procurou caracterizar e dimensionar o fenômeno com base em dados contábeis e informações publicamente disponíveis de 84 instituições do mercado.

Utilizou-se a análise gráfica associada à análise de correlação para avaliar o comportamento dos saldos das contas Depósitos antes e após a intervenção. Como resultado, os bancos foram segregados em 5 grupos. $\mathrm{O}$ grupo que agregou os maiores bancos do mercado passou a ser o grupo de controle para a análise. A delimitação do grupo dos bancos, presumivelmente, contagiados (grupo de estudo) possibilitou avaliar a evolução dos resgates de depósitos e o papel das carteiras de crédito e de títulos como provedoras de liquidez. A análise realçou a importância dos depósitos compulsórios sobre depósitos a prazo como reserva de liquidez.

Além disso, com base nas informações financeiras trimestrais (IFTs), foi possível segregar as carteiras de crédito e depósitos por tipo de cliente (pessoa física, jurídica ou governo) e verificar o impacto em cada um delas .

Determinou-se também o volume de créditos cedidos ao longo do período. Concluiu-se que houve uma mudança no perfil das carteiras de crédito dos bancos afetados, com um aumento do percentual aprovisionado para risco de crédito, aproximando-o dos valores do grupo de controle, que utiliza critérios mais conservadores. Atribuiu-se esse comportamento à redução nos saldos das carteiras classificadas como AA e A (menores níveis de risco). Umas das explicações para essa redução é que as cessões deram-se justamente nos créditos de menor risco.

No período analisado, o indicador provisão de crédito demonstrou ser pouco confiável para a previsão de deterioração financeira. Por outro lado, o indicador contábil de juros sobre a captação apresenta um aumento significativo, para o grupo de estudo, em julho de 2004, portanto antes da intervenção. Esse aumento, que persistiu até julho de 2005, poderia indicar o surgimento de expectativas negativas do mercado a respeito de problemas no segmento analisado e, posteriormente à intervenção, uma política para retenção de clientes.

Procurou-se, por fim, cotejar os eventos observados e as características do sistema financeiro brasileiro com o arcabouço teórico e empírico existente, principalmente em relação a dois aspectos: fundamentos que justificam o exercício da supervisão bancária e teoria das cascatas de informações analisada no âmbito das corridas bancárias. 


\begin{abstract}
The intervention in the Santos bank, in November 2004, has provoked a liquidity crisis on a specific segment of the Brazilian banking market.

The objective of this case study has been to assess and characterize the phenomenon, based on balance sheet data and public information about 84 financial institutions of the market.

Through graphical analysis associated with statistical correlation analysis, the behavior of the deposit account, before and after the intervention, was determined. As a result banks have been classified on five different groups. The group with the biggest banks was designed as the control group and banks that have showed loss of deposits and could have been, potentially, affected by a liquidity crisis were denominated as study group. The definition of the, presumable, contaminated group of banks has permitted to assess the evolution of deposits' withdraws as well as the role of the credit and security portfolios as providers of liquidity. The analysis has shown the importance of the reserve requirements over time deposits as a liquidity reservoir.

Besides, based on the quarter financial statements (IFT) it was possible to segregate the types of credit and deposit portfolios according with types of clients (households, firms and government), as well as to evaluate the impact over each of these portfolios.

It has also been determined the volume of credit transferred along the period of analysis. The conclusion is that the credit loss provision has augmented, getting closer to the values of the control group that uses more conservative provision standards. This behavior has been attributed to a reduction on credits classified as AA and A (less risky level). A possible explanation for the reduction is that transfers have been done mainly on less risky credits. Also, the credit loss provision indicator has demonstrated low reliability as an estimator of financial deterioration. The accounting indicator, Interest rates over deposits, has showed an increase for the study group, in July 2004, before intervention, and this increase has lasted until July 2005. The fact could indicate an anticipation by the market of financial deterioration on a bank or in the segment. After intervention, the increase could represent a strategy to retain clients.

This study has also evaluated the observed events and the characteristics of the Brazilian financial system, with theoretical and experimental background, mainly focusing two aspects: fundaments that justify the exercise of banking supervision and the theory of information cascades on basis of the bank runs.
\end{abstract}




\section{SUMÁRIO}

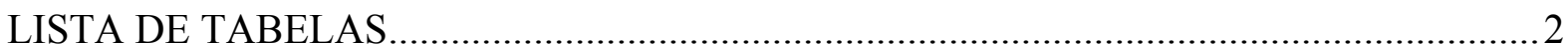

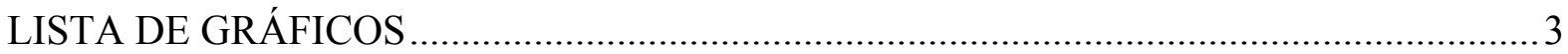

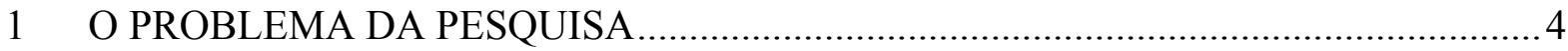

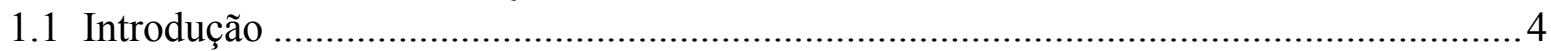

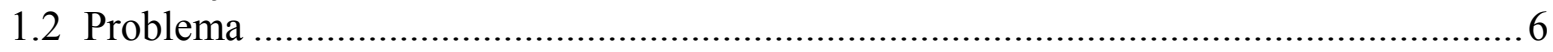

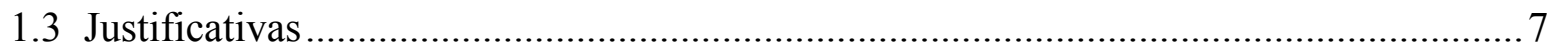

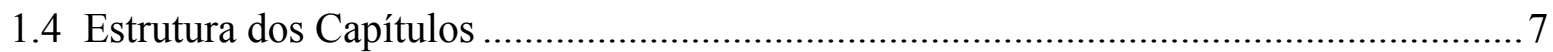

2 FUNDAMENTAÇÃO TEÓRICA ……………………......................................

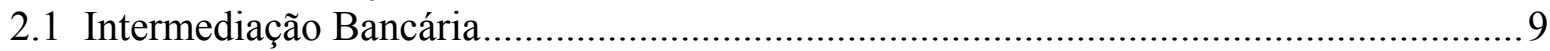

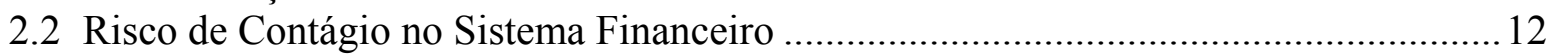

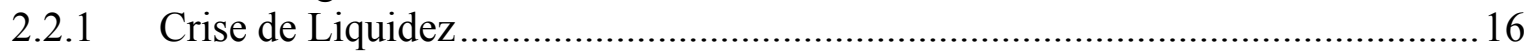

2.2.2 Corrida Bancária e Cascatas de Informações ......................................................22

2.3 Mecanismos de Mitigação de Crises Bancárias ………………………………..........28

2.3.1 Requerimento de Reservas e Narrow Banking ..................................................28

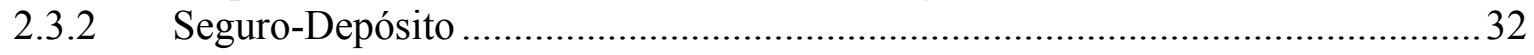

2.3.3 Regulação e Disciplina de Mercado ………………………………………….....38

3 INTERVENÇÃO NO BANCO SANTOS E EFEITO CONTÁGIO ………………….....45

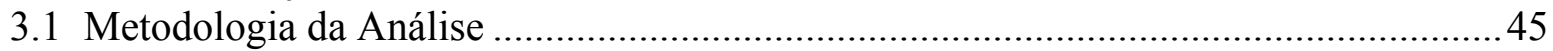

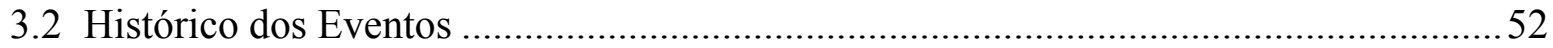

3.3 Percepção do Mercado sobre a Situação do Banco Santos ...........................................52

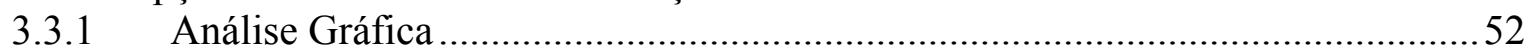

3.3.2 Análise de Correlações entre as Instituições …………………………………….....54

3.3.3 Benefício de Imagem....................................................................................58

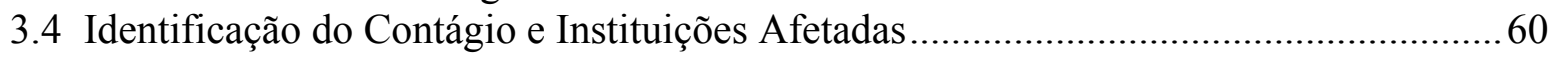

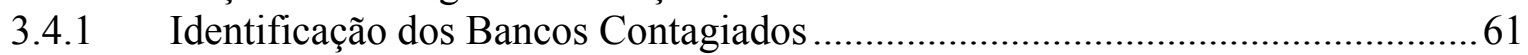

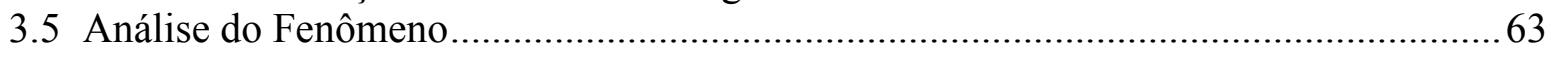

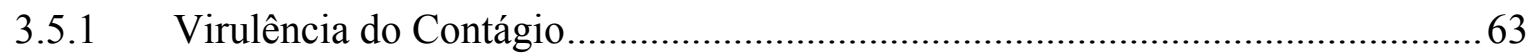

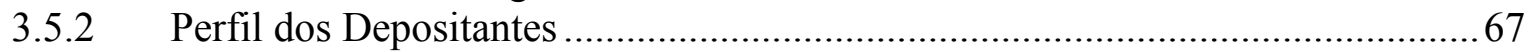

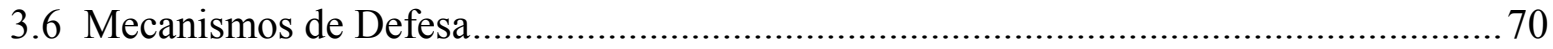

3.6.1 Estoque de Liquidez ………………………………..................................

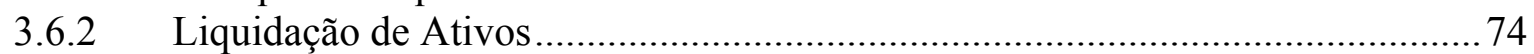

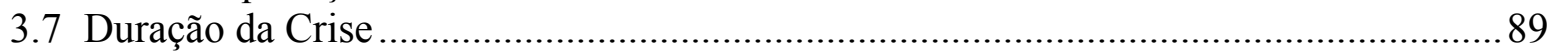

3.8 Fatores Determinantes do Contágio - Análise Discriminante. …………………............94

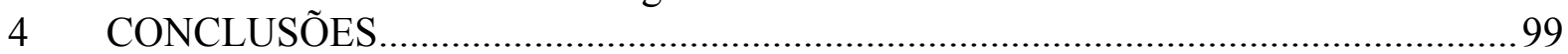

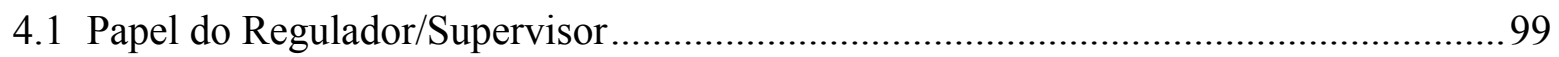

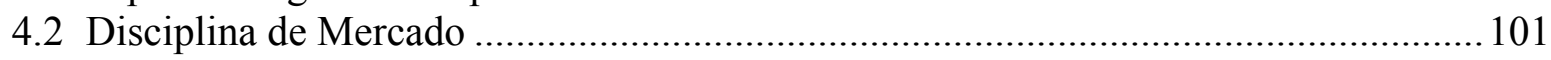

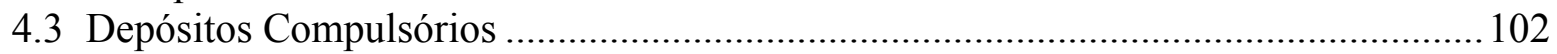

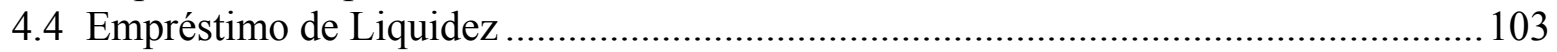

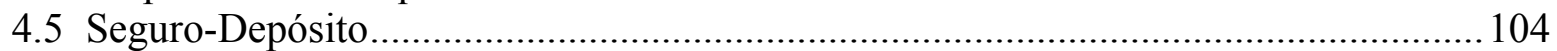

4.6 Surpresa do Mercado e Razões do Contágio................................................................ 104

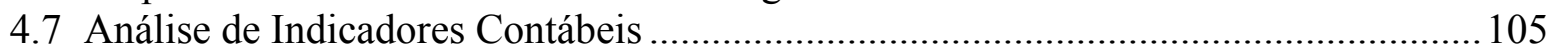

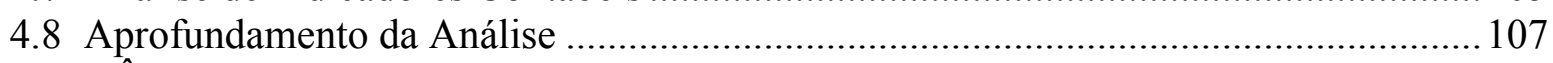

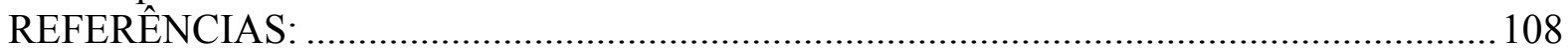

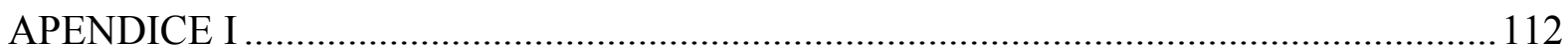

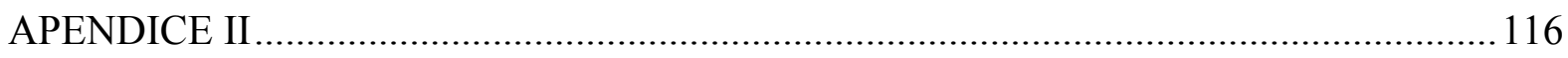

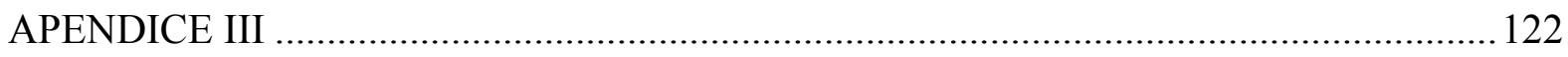

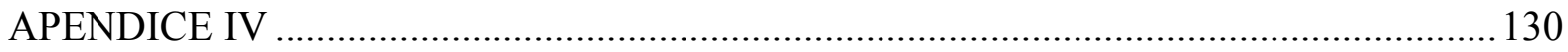




\section{LISTA DE TABELAS}

Tabela 1 - Comparativo amostra X Sistema Bancário Nacional .........................................49

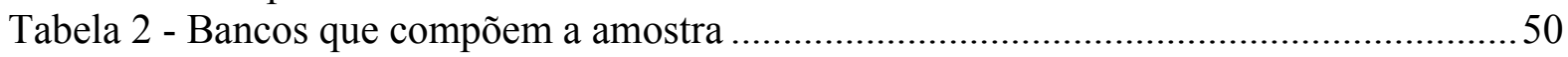

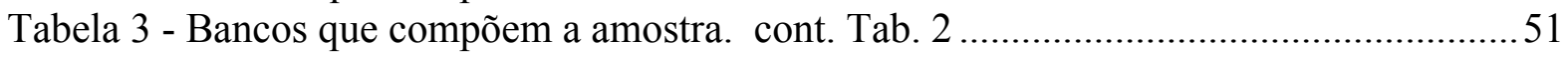

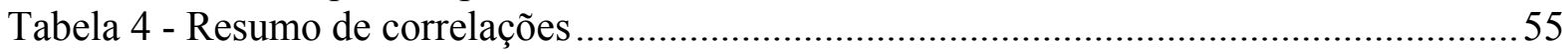

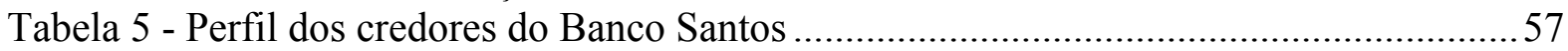

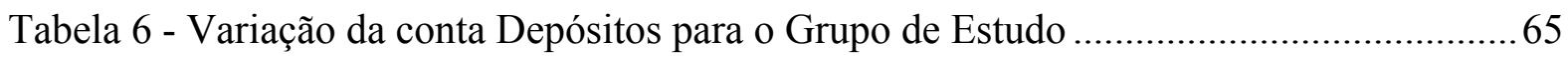

Tabela 7 - Fator de crescimento da conta Depósitos - base set. 2004 ..................................66

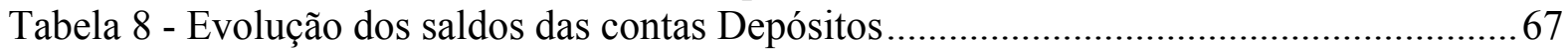

Tabela 9 - Evolução dos componentes da liquidez do Grupo de Estudo ...............................73

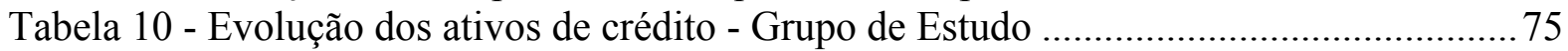

Tabela 11 - Fator de crescimento dos ativos de crédito - Grupo de Estudo ...........................75

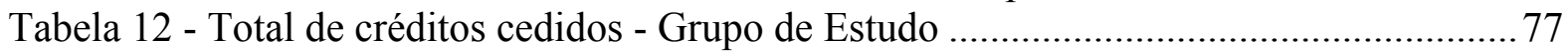

Tabela 13 - Teste da diferença das médias para a variável Jurosativo ..................................... 80

Tabela 14 - Teste da diferença das médias para a variável Jurosativo. Cont. Tab 13 .............81

Tabela 15 - Teste da diferença das médias para a variável Provisão .....................................82

Tabela 16 - Teste da diferença das médias para a variável Provisão. Cont. Tab.15 ...............83

Tabela 17 - Teste da diferença das médias para a variável Jurospassivo ..............................87

Tabela 18 - Teste da diferença das médias para a variável Jurospassivo. Cont. Tab.17 .........88

Tabela 19 - Teste da média da variação dos depósitos - Grupo de Estudo .............................90

Tabela 20 - Teste de igualdade das médias da variação de depósitos ...................................92

Tabela 21 - Teste de igualdade das médias da variação de depósitos. Cont. Tab. 20 .............93

Tabela 22 - Coeficientes da função discriminante.................................................................96

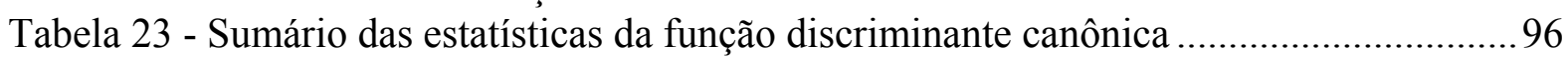

Tabela 24 - Resultados da análise discriminante...................................................................96 


\section{LISTA DE GRÁFICOS}

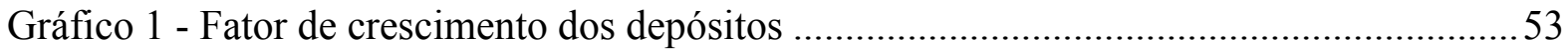

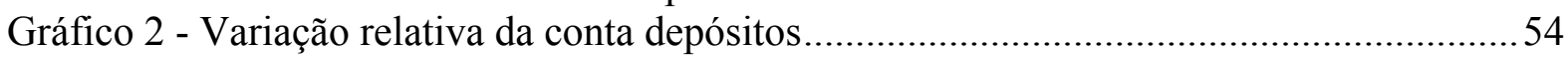

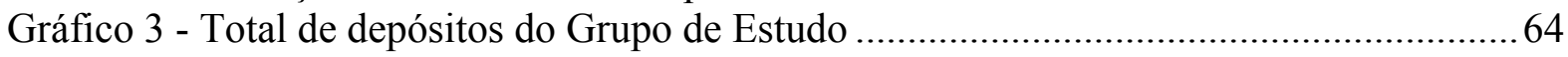

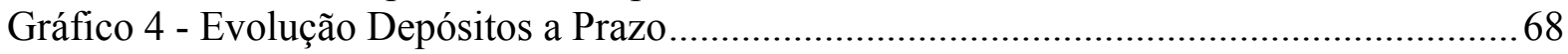

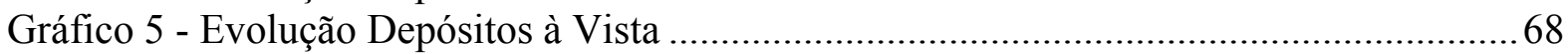

Gráfico 6 - Evolução Depósitos de Poupança ……........................................................................69

Gráfico 7 - Evolução dos principais ativos e passivos de maior liquidez - Grupo de Estudo.71

Gráfico 8 - Evolução dos componentes de liquidez do Grupo de estudo ...............................72

Gráfico 9 - Evolução dos ativos de crédito do Grupo de Estudo ...........................................76

Gráfico 10 - Evolução da participação por nível de risco da carteira do Grupo de Estudo.....84

Gráfico 11 - Evolução da carteira de crédito do Grupo de Estudo, por nível de risco ............85

Gráfico 12 - Evolução da carteira de crédito por nível de risco - Grupo Núcleo do Mercado 86

Gráfico 13 - Evolução da participação por nível de risco da carteira do Grupo Núcleo do

Mercado 


\section{1 O PROBLEMA DA PESQUISA}

\subsection{Introdução}

O sistema financeiro, com o passar do tempo, tornou-se participante imprescindível para o bom funcionamento da economia dos países. Essa aquisição de importância foi construída à medida que a indústria bancária incorporou novas atribuições ou redefiniu sua finalidade.

Basta lembrar que os bancos (BAGEHOT, 1935, p. 76-90) surgiram para desempenhar basicamente duas funções: prover financiamento para os mercadores e governos regionais; e assegurar o valor dos meios de pagamentos detidos pela população das regiões e países. Para a primeira atribuição, a origem das fontes de financiamento não era a poupança popular ou pulverizada e sim, recursos de grandes capitalistas. Já a segunda surgiu em virtude do intenso comércio regional que obrigava a população de um país, principalmente mercadores, a deter moedas de outros países. Essas moedas, pela própria circulação, apresentavam desgastes diferenciados devido ao uso intenso, o que provocava uma perda de valor intrínseco. $\mathrm{O}$ fato tornava o comércio incerto, pois o comprador só sabia a quantia certa a pagar a partir da análise da qualidade das moedas apresentadas. Os estados fomentaram a criação dos bancos regionais com a finalidade de, a partir do estabelecimento de determinados padrões, recolher esse numerário e registrar o crédito correspondente para o depositante. Essa troca era feita com deságio, de acordo com o estado da moeda entregue. Surgia a moeda escritural, pois o comércio passava a ser feito através da mera troca de registro contábil entre comprador e vendedor e o banco contava com a garantia do estado.

Desde então, a atividade bancária modificou substancialmente sua finalidade e passou a incorporar uma infinidade de funções, fruto também da extensa inovação tecnológica que vem ocorrendo. A presente dissertação atem-se à intermediação financeira que, apesar da incorporação de novas funções, pode ainda ser considerada o cerne da atividade bancária.

Por meio da interposição de um intermediário financeiro, pode-se captar a poupança difusa e pulverizada, seja em termos geográficos, seja em termos de valor individual, e direcioná-la para os agentes deficitários para finalidades que vão do consumo financiado ao próprio investimento em atividades produtivas da economia. A existência desse intermediário 
viabiliza o encontro entre esses dois tipos de agentes econômicos, independentemente de barreiras geográficas, lingüísticas, políticas, religiosas, etc. Outro aspecto fundamental da intermediação é a possibilidade de aglutinação de recursos esparsos para promover o financiamento de investimentos dos mais variados volumes e prazos. Surgem, na esteira dessas atribuições básicas, diversas economias de escala que propiciam a transferência desses recursos da maneira mais eficiente e segura possível: análise de risco de crédito, visão mais abrangente do mercado, transferência eletrônica dos recursos, possibilidade de resgate do depósito em qualquer prazo, guarda física dos valores, execução de pagamentos, etc.

No entanto, deve-se considerar que, para existir o negócio bancário - mais do que de uma complexa estruturação, materializada em uma extensa rede de agências bancárias voltadas para a drenagem e redistribuição dos recursos - ele depende fundamentalmente da existência de confiança. Principalmente, a confiança do depositante que receberá seus recursos de volta; e a do tomador, de que o dinheiro emprestado só será exigido no prazo previamente acordado.

Pela sua própria natureza, a intermediação financeira é uma atividade conduzida em um ambiente de desequilíbrio dinâmico, pois há um descasamento de prazos entre as fontes e os usos dos recursos. Em geral, as fontes (depósitos) são exigíveis em prazo bastante inferior às aplicações. A permanente conciliação desse aparente desequilíbrio é, na verdade, a principal virtude do negócio bancário e a essência de seu funcionamento. De maneira geral, nenhum banco está apto a resgatar boa parte de suas obrigações em curto espaço de tempo. Mesmo com o decorrer do tempo, a recuperação dos empréstimos concedidos, ainda que nos respectivos vencimentos, pode se mostrar inexeqüível já que no ambiente econômico as empresas enfrentam situações em que ora utilizam esses recursos para capital de giro e têm simplesmente que deixar de operar para poder honrar esses compromissos, ora demandam esses recursos para re-investimentos num quadro em que teriam sua sobrevivência ameaçada.

A essência do sistema, por paradoxal que pareça, é de que o depositante não resgatará e o devedor não pagará. Embora a instabilidade possa ser considerada como inerente a essa atividade, a evolução histórica dessa indústria permitiu construir um aprendizado, principalmente em decorrência dos eventos de crises de liquidez e quebras bancárias. Dado o impacto econômico e prejuízo à população depositante e dada à natureza peculiar da indústria, diversos mecanismos foram e vêm sendo constantemente incorporados à atividade com o propósito de reduzir incertezas e auferir credibilidade ao sistema. Destacam-se: a regulamentação e supervisão específica para a atividade financeira; a exigência de capital mínimo; a interposição dos depósitos compulsórios que limitam a 
capacidade de multiplicação da moeda; a inclusão de um emprestador de última instância; a divulgação (disclosure) das informações, com a necessidade de publicar balanços e informações relevantes e a necessidade de adotar boas práticas de governança corporativa e de controles internos. Mais recentemente, destaca-se a construção de uma nova regulamentação, mais moderna e arrojada, consubstanciada no novo acordo de capitais (Basiléia II), cujo cronograma de implementação está em andamento. Embora essas salvaguardas constituam eficientes sistemas de amortecimento de crises, sua eficácia dependerá da virulência da crise e se esta última vai se apresentar de forma disseminada (sistêmica) ou localizada.

O presente trabalho procura analisar um evento recente do mercado bancário brasileiro que poderia propiciar a ocorrência de crise de confiança no sistema financeiro. Trata da decretação pelo Banco Central do Brasil, em 12.11.2004, de Intervenção no Banco Santos.

\section{$1.2 \quad$ Problema}

A análise pretende encontrar respostas para as seguintes indagações:

a) Qual foi o segmento imediatamente afetado pela intervenção no Banco Santos? Que características desse segmento foram determinantes para vinculá-lo à crise do Banco Santos?

b) Quais foram as principais formas de contágio? O contágio derivou de comportamento irracional dos depositantes? A surpresa com a intervenção no Banco Santos foi o fator determinante para a propagação da crise de confiança?

c) Qual o perfil dos sacadores de recursos?

d) Qual o arsenal disponível e que tipo de mecanismos de defesa os bancos utilizaram para superar o contágio?

e) Qual o papel esperado e desempenhado pelo Banco Central para debelar a crise?

f) Em que prazo a crise se desenvolveu? Qual o prazo em que houve estabilização? 


\subsection{Justificativas}

A inegável importância dos sistemas financeiros para o funcionamento eficiente das economias modernas acarreta um risco subjacente, o da corrida bancária e seus efeitos deletérios decorrentes, que podem culminar numa crise sistêmica, com efeitos perversos para a economia como um todo.

Diversos fatores podem atuar como catalisadores de uma corrida bancária. Por exemplo, o surgimento de uma crise de confiança sobre a saúde do sistema financeiro, ou de instituições que dele participam; a ocorrência de crises econômicas, mesmo que setoriais, que sejam entendidas com elevado potencial para afetar solvência das instituições financeiras; ou mesmo, a insolvência de uma instituição que teria o condão de sinalizar para o mercado a possibilidade da situação espraiar-se para o restante do sistema.

A intervenção ocorrida no Banco Santos em 12.11.2004, parece representar uma situação intermediária visto ter apresentado um elevado poder de propagação para outras instituições, restringindo-se, porém, a instituições pequenas e médias, sem efeitos importantes para os bancos que representam a quase totalidade do sistema financeiro.

A crise bancária ocorrida, apesar de seu caráter restrito, representa uma oportunidade singular e de suma importância para um melhor entendimento do fenômeno, para avaliar a eficácia dos mecanismos de contenção existentes ou criados para a situação, bem como, para conduzir uma análise empírica sobre o comportamento de diversos indicadores contábeis. Uma importância acessória desse estudo é de contribuir para o registro histórico de um evento de baixa recorrência na indústria bancária.

\subsection{Estrutura dos Capítulos}

A presente dissertação esta estruturada em quatro capítulos. No primeiro capitulo é apresentada uma breve introdução, os objetivos ou problemas da pesquisa, e a justificativa para sua execução.

O segundo capítulo contém a fundamentação teórica e apresenta um breve histórico sobre a evolução do sistema financeiro, suas virtudes para as economias modernas e o dilema do descasamento de prazos, que acaba desaguando no risco de crise sistêmica. O capítulo 
aborda também o surgimento e função da supervisão bancária, o efeito-contágio sob a ótica teórica e das cascatas de informações e resultados empíricos de eventos de contágio e prevenção de crise.

O terceiro capítulo descreve a metodologia de pesquisa e descreve o procedimento de amostragem e as instituições escolhidas para a análise. Em seguida, é caracterizado o ambiente em que ocorreu a intervenção no banco Santos, definido o universo de instituições possivelmente contagiadas e avaliado o impacto do contágio na estrutura patrimonial dessas instituições. São também analisados aspectos de liquidez e de recuperação de ativos assim como o comportamento de alguns indicadores contábeis das instituições contagiadas e não contagiadas. O capítulo se conclui com um estudo de análise discriminante para avaliar quais indicadores contábeis melhor reproduzem a segregação pelo mercado entre instituições contagiadas e não contagiadas.

No último capítulo são apresentadas as conclusões e as possíveis respostas às questões inicialmente formuladas. 


\section{FUNDAMENTAÇÃO TEÓRICA}

\subsection{Intermediação Bancária}

A intermediação bancária, ao possibilitar que os recursos dos poupadores (agentes superavitários) sejam canalizados para investidores (agentes deficitários), constitui tarefa crucial para o funcionamento e eficiência do sistema econômico.

É interessante destacar que, com a evolução do sistema bancário e sua incorporação ao cotidiano das pessoas, essa condição de intermediário perde substância e o banco passa a ser visto como ente autônomo. O poupador empresta para o banco. O tomador toma emprestado do banco.

A lógica é também amparada juridicamente porque o banco é o único responsável pela devolução dos valores que lhe foram confiados bem como pelo cumprimento dos termos acordados nos empréstimos efetuados. Deve-se considerar, porém, que mesmo essa garantia jurídica só se concretiza mediante a existência de um equilíbrio dinâmico no fluxo de recursos entre devedores e tomadores. Qualquer quebra inesperada desse fluxo, seja pelos devedores não honrarem seus compromissos, seja pelos credores exigirem seus valores de volta, pode acarretar severa ruptura desse equilíbrio; pode causar até a insolvência da instituição com efeitos deletérios para os depositantes e, de acordo com a dimensão dessa quebra, com potencial para se disseminar ao restante do sistema e até provocar uma crise sistêmica.

A transformação de ativos ilíquidos em ativos líquidos é responsável tanto pela existência dos bancos quanto pela sua vulnerabilidade às corridas bancárias (DIAMOND; DYBVIG, 1983, p. 403).

Essa característica da atividade, o fato de receber poupança popular e sua condição atual de sistema essencial para o funcionamento da economia de qualquer país, determina que o sistema financeiro receba supervisão e tratamento regulamentar específico. Saunders (2000, p. 79), examina a natureza especial dos intermediários financeiros, as funções desempenhadas e os ganhos que a escala de operação propicia para a sociedade ou clientes:

- Custo de informação: o intermediário financeiro, ao aglutinar os recursos individuais de diversos poupadores, executa para eles a coleta de informações sobre os tomadores de recursos, reduzindo substancialmente o custo da obtenção da informação. Além 
disso, a freqüente renovação de contratos de crédito, principalmente de curto prazo, permite ao intermediário financeiro obter maiores informações sobre os diferentes negócios e clientes, aprimorando, com o passar do tempo, sua capacidade de análise;

- Liquidez e risco de variação de preço: os intermediários financeiros, por meio da diversificação das carteiras, conseguem oferecer aos poupadores contratos de elevada liquidez com baixo risco de variação de preço ao mesmo tempo em que aplicam em ativos de liquidez relativamente baixa e risco mais elevado;

- Redução de custos de transação: o agrupamento de ativos permite que os intermediários financeiros adquiram ações ou títulos em grandes quantidades (por exemplo em fundos mútuos) a custos de transação ou corretagem proporcionalmente inferiores aos que os clientes individualmente pagariam;

- Intermediação de prazos: os intermediários financeiros, seja pela diversificação, seja pelo volume operado, têm uma maior capacidade de diminuir o descasamento de prazo entre ativos e passivos do que os poupadores individuais. Além disso, eles possuem maior poder de gerenciar esses descasamentos por meio de instrumentos de hedging, tais como vendas de empréstimos e operações de securitização e acesso a diversos tipos de contratos futuros e de derivativos;

- Serviços de pagamentos: o bom funcionamento de uma economia moderna depende da existência de um sistema de pagamento eficiente;

- Transmissão da política monetária: como os passivos das instituições financeiras representam parcela significativa da oferta de moeda, que por sua vez influencia a taxa de inflação, as instituições depositárias e os bancos comerciais desempenham papel fundamental na transmissão da política monetária do Banco Central para o restante da economia;

- Alocação de crédito: por vezes, as instituições financeiras são a única fonte de financiamento para setores específicos da economia, tais como o setor imobiliário e a agricultura que, freqüentemente, são alvos de programas especiais do governo.

A crescente importância do sistema financeiro foi apresentada por Bagehot (1935, p.5) em publicação cuja primeira edição ocorreu em 1873:

....Um milhão nas mãos de um único banqueiro representa um poder enorme; ele pode emprestálo imediatamente para quem ele quiser, e os tomadores podem vir a ele, já que eles sabem ou pelo menos acreditam que ele terá esses recursos. Por outro lado, a mesma quantia pulverizada em 10 ou 50 vezes por toda uma nação não representa nenhum poder: ninguém sabe onde encontrá-la ou a quem procurar para conseguí-la. A Concentração do dinheiro nos bancos, embora não seja o 
único, pode ser considerado o motivo principal de o mercado monetário da Inglaterra ter atingido uma riqueza tão exuberante, muita além dos demais países ${ }^{1}$.

O modelo de Diamond e Dybvig (1983, p.402) aponta três importantes características do sistema financeiro:

- A captação, através de depósitos à vista pelos bancos, permite aumentar a competitividade do mercado ao prover uma melhor diluição do risco entre pessoas que tencionam consumir em distintas épocas. Nessa atividade, os bancos proveriam seguro para que os agentes consumissem quando desejassem;

- A condição de saque à vista implícita nesses depósitos acarreta o surgimento de um equilíbrio indesejável que seria a corrida bancária, na qual todos os depositantes entram em pânico e procuram sacar seus recursos imediatamente. Inclusive aqueles que prefeririam manter seus recursos depositados caso não estivessem preocupados com a solvência do banco;

- As corridas bancárias podem ocasionar problemas econômicos reais pois, mesmo os bancos saudáveis, podem vir a tornarem-se insolventes tendo que resgatar empréstimos concedidos e inviabilizando a continuação de investimentos produtivos.

Bagehot (1935, p.232) avalia que o capital em um banco é necessário apenas para assegurar uma influência moral ou a confiança do público. O reduzido capital seria na verdade a maior fonte de lucratividade do banco, pois lhe permitiria garantir um bom lucro, tendo em vista a elevada quantidade de recursos disponíveis, mesmo considerando uma baixa taxa de aplicação desses recursos.

É interessante o comparativo apresentando por Bagehot (1935, p.261-270) sobre as diferenças, em 1873, entre bancos com controle particular e com capital aberto. Na sua visão, o administrador de um banco com controle pulverizado, ou pelo menos disperso, é um profissional devotado exclusivamente a essa atividade e satisfaz-se em viver exclusivamente dela. O banco particular, por sua vez, seria administrado pelos donos, em geral homens ricos, com pouca condição de conhecer o negócio com o devido detalhamento e com pouca disposição de dedicar suas vidas inteiras para essa atividade exclusiva.

Com um aumento do tamanho dos bancos, a tendência natural é uma melhora na qualidade da organização o que, no caso dos bancos particulares, implicaria em

\footnotetext{
${ }^{1}$ A million in the hands of a single banker is a great power; he can at once lend it where he will, and borrowers can come to him, because they know or believe that he has it. But the same sum scattered in tens and fifties through a whole nation is no power at all: no one knows where to find it or whom to ask for it. Concentration of money in banks, through not the sole cause, is the principal cause, which has made the Money Market of England so exceedingly rich, so much beyond that of other countries.
} 
profissionalizar a gestão. Os proprietários não deveriam se preocupar com os detalhes da operação e sim constituir um comitê consultivo permanente, com a participação dos gerentes, para supervisionar a ação desses gerentes, para opinar sobre a concessão de empréstimos elevados e para definir princípios e objetivos de atuação.

Apesar da época, a visão de Bagehot pode ser considerada bastante adequada para compreender o cenário contemporâneo e remete diretamente aos atuais princípios de governança corporativa.

Bagehot $(1935$, p.8) apresenta um panorama bastante interessante sobre a mudança de paradigma propiciada pelo crescimento da indústria bancária:

Se um comerciante tem um capital de $₫ 50,000$, - para ganhar $10 \%$ ao investi-lo ele teria que receber $£ 5,000$ por ano, e teria que vender suas mercadorias de acordo com essa margem requerida; contudo, se outro comerciante tiver apenas $£ 10,000$, e tomar emprestado $£ 40,000$ através do desconto de recebíveis (o que pode ser considerado comum no comércio moderno), ele teria o mesmo capital de $£ 50,000$ para usar, e vender muito mais barato. Se a taxa de empréstimo for de $5 \%$, ele terá que pagar $£ 2,000$ por ano; se, como o outro comerciante, ele conseguir um lucro de $£ 5,000$ por ano, ele terá, após pagar os juros, obtido $£ 3,000$ ao ano, ou $30 \%$, sobre seus $£ 10,000$. Como muitos comerciantes estarão satisfeitos com muito menos que isso, ele poderá, se quiser, abdicar de parte do lucro, baixar o preço da mercadoria e tirar o comerciante antigo - que opera com seu próprio capital - do mercado $^{2}$.

\subsection{Risco de Contágio no Sistema Financeiro}

O efeito contágio puro pode ser conceituado como aquele em que informações negativas sobre um banco, tais como fraude ou perdas em investimentos específicos, se propaga para outros, inclusive para aqueles que não tenham nada em comum com o banco atingido. O outro tipo de contágio seria o secundário, ou ruído, surge quando a insolvência de um banco revela um sinal ruim relativamente a outros bancos com características comuns, por exemplo de estrutura de ativos e passivos assemelhados. Em um mundo de informação imperfeita, corridas para outros bancos podem iniciar-se por similaridades percebidas e não necessariamente reais (AHARONY; SWARY, 1983, p.306). Segundo esses autores, para se

\footnotetext{
2 "If a merchant have $£ 50,000$ all his own, - to gain 10 per cent on it he must make $£ 5,000$ a year, and must charge for his goods accordingly; but if another has only $£ 10,000$, and borrows $₫ 40,000$ by discounts (no extreme instance in our modern trade), he has the same capital of $£ 50,000$ to use, and can sell much cheaper. If the rate at which he borrows be 5 per cent, he will have to pay $£ 2,000$; and if, like the older trader, he make $£ 5,000$ a year, he will still, after paying his interest, obtain $£ 3,000$ a year, or 30 per cent., on his owns $£ 10,000$. As most merchants are content with much less than 30 per cent, he will be able, if he wishes, to forego some of that profit, lower the price of the commodity, and drive the old-fashioned trader - the man who trades on his own capital - out of the market."
} 
identificar o tipo de contágio, se puro ou secundário, deve-se considerar em que medida a informação proporcionada pela falência de determinada instituição se relaciona com outras.

Da mesma forma, Slovim et. al. (1999, p. 201), avalia que o contágio decorre da propagação de informação assimétrica, pois o depositante não consegue distinguir problemas específicos de um banco, de problemas derivados de fenômenos sistêmicos.

Lang e Stulz (1992, p.47) consideram que um anúncio de uma concordata $\left(\right.$ bankruptcy $\left.^{3}\right)$ afeta a avaliação das demais empresas do setor de duas formas: o efeito contágio e o efeito competição. No primeiro caso, o efeito produz uma perda de valor das empresas do mesmo setor uma vez que o anúncio conduz novas informações sobre o valor presente dos fluxos de caixa dessas empresas, pois eles apresentam alta correlação com o fluxo da empresa concordatária. No segundo, o efeito conduz a um ganho de valor, pois a solicitação da concordata transmite novas informações sobre a situação competitiva presente e futura do segmento. $\mathrm{O}$ efeito competição seria tão mais benéfico quanto maior a concentração econômica do setor de atuação e quanto menor o endividamento da empresa. Em setores altamente competitivos, o ganho potencial da eventual saída de uma empresa é restrito e um elevado endividamento reduz a habilidade para investir, inclusive para obter novos recursos, e para explorar mudanças em seu ambiente competitivo.

Jackson e Madura (2004, p. 30) avaliaram a influência dos profits warnings, alertas das empresas ao mercado sobre expectativa de lucros inferiores às previsões do mercado. A conclusão foi que os anúncios produzem efeito negativo no preço das ações dos bancos, que divulgam esses avisos bem como sobre seus rivais, confirmando que essa divulgação conduz informação nova ao mercado. Na verdade, um dos objetivos desses avisos é de reduzir a assimetria de informações entre insiders, acionistas e clientes. O comparativo sobre os efeitos no setor bancário e não bancário concluiu que a redução dos preços das ações, devido à publicação de alertas de lucro, é significativamente maior no setor não bancário. Essa distinção de comportamento, na visão dos autores, advém do fato de o setor bancário ser fortemente regulado o que implicaria num monitoramento do supervisor bancário, seja para adotar medidas corretivas, seja para preservar o nível de capital, o que funcionaria como um limitador de risco de deterioração.

Aharony e Swary (1983, p. 320-321) analisando a existência de efeito contágio no mercado financeiro, nos eventos críticos anteriores à falência de três grandes bancos americanos, concluíram que o contágio puro não foi confirmado pelos dados. Os resultados

\footnotetext{
${ }^{3}$ Bankruptcy, na terminologia aqui empregada, corresponde à previsão do capitulo 11 da lei de falências americana, ou seja, corresponde a um regime de administração financeira diferenciado.
} 
indicaram que em dois bancos que faliram devido a problemas específicos, fraudes e irregularidades internas, o contágio não ocorreu. Segundo eles, isso indicaria que falências decorrentes de gestão desonesta, mesmo que em uma grande instituição, não acarretam necessariamente pânico ou perda de confiança do público em relação ao sistema bancário. No terceiro banco analisado, a falência deveu-se a perdas no mercado de câmbio, que era um mercado comum também a outras instituições. A interpretação foi que o impacto negativo representado pela desvalorização no preço das ações dos demais bancos deveu-se não a um sintoma de contágio puro, mas sim à leitura realizada pelos investidores de um sinal negativo sobre a performance desses bancos.

Schoenmaker (1996, p.99) considera que, modernamente, as crises bancárias passam a ser fortemente influenciadas pelos bancos centrais, no exercício de seu papel de mantenedor da estabilidade do sistema bancário. Portanto, para avaliar a efetiva ocorrência do efeito contágio, ele constrói um modelo utilizando dados de falências bancárias ocorridas nos Estados Unidos entre 1880 e 1919 e entre 1920 e 1936, períodos em que a atuação do Banco Central americano não existia ou então foi menos intensa (até 1933). Sua conclusão foi que, mesmo considerando a influência de variáveis macroeconômicas, existe uma forte dependência entre o número de falências num determinado período de tempo; e que essa influência se estende por um intervalo de até três meses, o que confirmaria o efeito contágio. A dependência verificada foi bem mais forte no período da Grande Depressão, indicando que as falências foram mais influenciadas pelo efeito contágio do que por fatores macroeconômicos.

Gupta et. al. (2005, p.7) utilizando-se de amostra de 36 crises bancárias ocorridas em 35 países, no período de 1980 a 1995, concluíram que, diferentemente do passado, as crises bancárias modernas não derivam do surgimento de pânico e das conseqüentes corridas bancárias. As hipóteses, não mutuamente excludentes, que poderiam justificar essa conclusão, seriam: que, mesmo em crises agudas pode existir um segmento bancário que seja vislumbrado como de relativa segurança e para o qual os clientes passariam a transferir seus recursos; a outra, seria que vários dos países analisados contavam com uma rede de proteção que incluiria o seguro-depósito, o emprestador de última instância e a ajuda governamental para bancos problemáticos.

Diamond e Dybvig (1983, p. 413) tecem comentário sobre a definição de um montante de resgate máximo a partir do qual os bancos deixariam de atender as solicitações dos clientes. Se por um lado a limitação poderia representar um fator de tranqüilidade para os poupadores de longo prazo, que não teriam interesse em sacar seus recursos naquele 
momento, por outro, poderia ser economicamente ineficiente. A estipulação desse valor máximo teria caráter arbitrário e dificilmente corresponderia à demanda dos poupadores que requisitassem o resgate, mesmo nas situações de normalidade. Nesse arranjo, certamente alguns clientes seriam prejudicados, pois não poderiam sacar os seus recursos.

Eles consideram o seguro-depósito o melhor mecanismo de proteção aos depósitos e que esse seguro deve ser necessariamente controlado pelo governo (Ibid., p.413). A atribuição dessa atividade à iniciativa privada esbarraria na imprevisibilidade e no elevado montante das reservas a serem constituídas para prover a garantia necessária. Já o governo tem o poder de instituir impostos sobre os agentes, em particular sobre os agentes que resgataram seus recursos antecipadamente. O montante de impostos a ser recolhido dependeria tanto do total efetivamente resgatado quanto do valor que se pretendesse resgatar, pois o governo pode estabelecer o valor a ser tributado após a ocorrência. Esse tipo de política inibiria a corrida bancária, pois os clientes saberiam de antemão que seriam posteriormente penalizados por meio do recolhimento de impostos sobre a quantia sacada. Nesse modelo, não foi considerado o fator risco nos portfolios dos bancos. Claramente, a introdução do seguro-depósito afeta o processo de escolha das carteiras dos bancos e riscos associados e pode induzir o surgimento do risco-moral ("moral hazard"). Portanto, a implementação de um seguro-depósito dever estar, necessariamente, associada a algum tipo de regulação bancária.

Diamond e Dybvig (1983, p. 418) observam, ainda, que a garantia proporcionada pelo seguro-depósito permite que os bancos forneçam seguro-liquidez para as empresas. Essa função deriva do fato de os bancos deterem a maior parte das dívidas de curto prazo das empresas bem como das garantias prestadas para as emissões diretas de dívidas das empresas. De acordo com essa visão, a maior parte do risco de liquidez da economia americana, é suportada pelos intermediários financeiros.

Um contrato de depósito bancário estabelece que os depositantes, ao solicitar o resgate de seus recursos, serão atendidos até que os recursos detidos pela instituição bancária estejam exauridos. Essa premissa "primeiro a chegar, primeiro a ser atendido" conduz a duas possibilidades de auto-equilíbrio. O equilíbrio bom, para o qual todos acreditam que apenas aqueles que tenham necessidade de liquidez irão sacar seus recursos antecipadamente; e o ruim, no qual todos acreditam que todos irão resgatar. Dada a prerrogativa do "primeiro a chegar primeiro a ser atendido" e o conhecimento que a liquidação antecipada dos ativos pelos bancos implica em perdas, todos os depositantes correm para sacar seus recursos (MORRIS, 1998, p.12). 


\subsubsection{Crise de Liquidez}

Segundo Bagehot (1935, p. 49-53), a ocorrência de uma crise não deve ser considerado apenas um problema do sistema bancário e sim, um problema mercantil, pois todo comerciante tem algum tipo de dívida que só pode ser paga mediante o desconto de duplicatas de outros comerciantes. No estágio inicial de uma crise financeira, esses agentes atuam de forma preventiva e procuram fortalecer sua posição financeira tomando empréstimos em volume superior às suas necessidades usuais. $\mathrm{O}$ banco, por sua vez, procura não deixar de atender o cliente regular para não sinalizar uma possível situação de falta de liquidez. Numa circunstância de mercado alarmado, em que a falência de uma empresa por falta de crédito pode se propagar para outras, os bancos devem continuar emprestando normalmente. Isto é, mantendo os mesmos critérios de seleção de clientes e de títulos oferecidos em desconto ou garantia.

Diamond e Dybvig (1983, p. 401) tecem consideração semelhante. Num evento de corrida aos bancos, os depositantes têm uma expectativa de falência da instituição e tentam sacar seus depósitos imediatamente. Ante uma demanda inesperada de recursos, os bancos podem ter que liquidar seus ativos com perdas, o que pode efetivamente acarretar sua insolvência. Numa situação de pânico, pode haver uma propagação para outros bancos que também se tornam insolventes podendo redundar numa ruptura do sistema monetário e redução de produção da economia. Os autores consideram que o impacto na produção, do resgate de empréstimos, pode ser em grande medida apontado como fator responsável pela Grande Depressão ocorrida na economia americana, em 1929.

Uma importante constatação empírica sobre o sistema bancário é que o tipo de organização do sistema bancário é um aspecto determinante crítico da propensão da economia a apresentar o fenômeno de pânico. Um sistema com poucos bancos grandes e com atuação bem diversificada e bem distribuída geograficamente tem uma propensão menor de sofrer uma corrida do que um sistema constituído por bancos pequenos e especializados (GORTON; HUANG, 2002b, p. 3). Nessa análise, bancos pouco diversificados nas suas operações acabam se expondo a riscos idiossincráticos o que provoca uma volatilidade nos resultados, portanto, maior risco de insolvência. Já nos bancos grandes a variedade de operações e o espalhamento geográfico resultam em diversificação e o risco passa a ser a soma do risco sistêmico com a média do risco idiossincrático. 
O potencial de geração de externalidades negativas oriundas de problemas em determinados bancos sobre o resto do sistema bancário e, conseqüentemente, para as empresas e famílias, é apontado como um dos principais motivos para a necessidade da existência de regulação e monitoramento das atividades bancárias. Ao executar essas atividades o governo busca garantir a estabilidade do sistema bancário bem como o funcionamento tranqüilo dos sistemas de pagamentos (SLOVIN et. al., 1999, p. 198).

Bagehot (1935, p. 53-54) apresenta a contradição da situação de crise financeira: por um lado, os bancos devem manter uma reserva para uma situação de crise; e, por outro, essa mesma reserva deve funcionar como fundo emprestador de última instância. Essa dicotomia na verdade não existe, pois a reserva deve se prestar não só a atender a demanda por dinheiro, mas também, em determinados casos, ela deve ser efetivamente fonte para empréstimos. Bagehot considera que uma situação de alarme deriva do receio dos credores em relação ao financiamento provido a seus devedores. A melhor forma de enfrentar essa situação seria provendo recursos a esses devedores para que eles possam honrar esses compromissos sendo que, para isso, uma pequena quantia de dinheiro seria necessária. Se essa situação de alarme não for prontamente enfrentada, ela pode se deteriorar para um pânico.

Ainda segundo Bagehot (1935, p. 54), o fornecimento de crédito pelos bancos não implica em que necessariamente haja uma diminuição das reservas. Muito provavelmente, os recursos correspondentes ao crédito concedido sequer serão sacados, mas se isso ocorrer, será mediante a transferência para crédito de outro cliente, que também os deixará em sua conta corrente. $\mathrm{O}$ aumento do crédito pelos bancos seria um aumento de passivo e não uma redução de reservas.

Numa situação de pânico, se a reserva estivesse baixa, não haveria meio de recompô-la. Na crise, o detentor de dinheiro, ou tomador dos empréstimos, só o devolveria se tivesse certeza de que receberia da mesma forma de outra pessoa. Se o banco se recusa a emprestar ou descontar títulos, que é a base da atividade comercial, os detentores desses títulos descontados não terão como resgatá-los. Numa situação de crise, os comerciantes estarão sob intensa pressão financeira e dificilmente abririam mão de qualquer recurso que pudessem considerar necessário para garantir sua sobrevivência.

Segundo Bagehot (1935, p.187), os empréstimos numa situação de pânico deveriam ser concedidos segundo dois princípios básicos: a uma taxa de juros bastante elevada, de forma a penalizar um alarmismo irracional e inibir demandas desnecessárias ou por motivo de precaução; e os adiantamentos só deveriam ser concedidos para títulos de boa qualidade, 
uma vez que a recusa de um título considerado bom pode sinalizar uma situação de baixa liquidez.

Interessante de se notar (ISHIHARA, 2005, p. 2) que a despeito da freqüência da ocorrência de crises nas economias desenvolvidas, embora exista um razoável consenso sobre a conceituação dos tipos de crise, há uma relativa controvérsia sobre a caracterização de uma crise do ponto de vista operacional.

A conceituação operacional deve garantir consistência com a conceituação teórica, assegurar uma padronização da análise bem como delimitar os períodos de crise e de nãocrise. Para atingir esse objetivo devem ser definidos indicadores representativos de cada tipo e estabelecidos padrões que definam a região de crise ou de normalidade.

Os estudos existentes abordam, geralmente, cinco tipos ou naturezas de crise:

- Balanço de pagamentos - perda abrupta de reserva ou, segundo Krugman e Obstfeld (1997, apud ISHIHARA, 2005, p. 2-3), variação brusca das reservas oficiais seguida de uma mudança nas expectativas sobre a taxa de câmbio;

- De moeda - depreciação abrupta da moeda ou, conforme Glick e Hutchison (1999, p. 6 apud ISHIHARA, 2005, p. 3), uma grande mudança em alguns indicadores dos valores reais ou potenciais da moeda;

- De dívida - inabilidade dos devedores em efetuar os pagamento em dia dos juros e principal da dívida, Dornbusch (1999, p. 301 apud ISHIHARA, 2005, p. 4);

- Financeira - a despeito de sua freqüência, não existe consenso sobre uma definição conceitual. Alguns estudos a definem como uma combinação das demais. Por exemplo, o FMI (1998, p. 75, apud ISHIHARA, 2005, p. 4) a define como uma disrupção potencialmente severa dos mercados financeiros que, ao prejudicar o funcionamento normal dos mercados, pode acarretar enormes efeitos adversos na economia real;

- Bancária - Ishihara (2005, p. 8) avalia que essa conceituação pode ser dividida em crise de liquidez, que em sua essência seria caracterizada pela corrida bancária ou pela impossibilidade de o banco, embora com patrimônio líquido íntegro, conseguir honrar suas obrigações imediatas e, insolvência na qual as obrigações do banco superam seus ativos, a valor presente, caracterizando a falência da instituição.

Destaque-se a existência de inter-relação entre os diferentes tipos de crise mencionados e a crise bancária analisada por Ishihara (2005, p. 17):

- Um setor bancário fraco pode propiciar o surgimento de uma crise de moeda se os especuladores, agindo racionalmente, anteciparem que, para evitar falências ou mesmo o 
aumento da pressão no setor bancário, as autoridades permitirão um aumento de liquidez, e portanto de inflação, com prejuízo para a estabilidade da taxa de câmbio. Além disso, deve-se considerar a possibilidade de movimentos de capital em busca de bancos ou ativos mais seguros no exterior, exercendo ainda maior pressão sobre a taxa de câmbio;

- A crise do setor bancário pode interromper o suprimento de crédito para as famílias e empresas, reduzindo o investimento e o consumo, tornando empresas viáveis insolventes, enfim, trazendo uma série de efeitos deletérios à economia do país;

- O desdobramento de uma crise bancária para uma crise de moedas pode afetar negativamente o balanço de alguns clientes, gerando inadimplência, obrigando os bancos a rolar essas dívidas ou até tornarem-se insolventes;

- Por outro lado, uma crise de moeda pode exigir uma elevação brusca da taxa de juros doméstica o que, a depender da estrutura do balanço das instituições financeiras, pode ser altamente danoso;

A análise de diversos eventos de crise demonstra um aumento das inter-relações entre os diversos tipos de crise no passado recente, sugerindo a necessidade de adoção de políticas destinadas a mitigar o risco de difusão de crises a partir da observação de uma crise de determinado tipo. Por exemplo, a ocorrência de uma crise de moeda deve ensejar uma preocupação quanto ao seu potencial para gerar uma crise de liquidez bancária (ISHIHARA, 2005, p. 24).

Gupta et. al. (2000, p. 21) verificaram que, embora seja conceito corrente que a redução do crédito provocado por uma crise financeira pode provocar um impacto na economia real e ajudar na propagação de choques adversos, os eventos contemporâneos de crise bancária não parecem ser seguidos por recessões prolongadas. A redução do crescimento da produção é normalmente aguda porém, de curta duração, sendo que as taxas de crescimento retornam ao nível anterior à crise no segundo ano após o término desta. $\mathrm{Na}$ amostra utilizada, verificou-se que a crise bancária é acompanhada de um brusco declínio da produção, em média de $4 \%$, contudo, deve-se realçar que a própria crise bancária pode ter sido uma conseqüência de choques adversos na economia e não o oposto. Contudo, se a crise bancária fosse um fator preponderante para a deterioração econômica, era esperado que as operações de crédito declinassem concomitantemente à redução da produção da economia. Observou-se, no entanto, uma redução menor dos saldos das operações de crédito em relação à queda do PIB, acarretando um aumento da relação CRÉDITO/PIB no período posterior à crise. Por outro lado, no segundo e terceiro ano após a crise, quando o PIB retornou aos 
níveis anteriores à crise, o crescimento das operações de crédito permaneceu estagnado, indicando que a retomada não foi determinada pela reassunção da concessão de crédito. Essa evidência contraria a hipótese de que a falta de crédito contribui de forma significativa para a redução da produção após uma crise bancária e que a retomada das concessões é uma condição necessária para a retomada do crescimento da produção. Aparentemente, assim que as condições macroeconômicas melhoram, as empresas conseguem utilizar outras fontes de financiamento, tais como: fornecedores, financiamentos internos, crédito externo, emissão de ações ou dívida. Essa constatação não é conclusiva, pois a variação do estoque de crédito é uma medida imperfeita do total de fundos efetivamente disponibilizados para os clientes. Parte do incremento pode refletir a apropriação de juros para impedir o reconhecimento de inadimplência. Por outro lado, o menor crescimento após a crise pode resultar de reestruturações de operações, de securitizações ou da redução do valor real da carteira em virtude do aumento da inflação, visto que a análise foi conduzida em valores reais.

Verifica-se, no entanto, que a preocupação com possíveis repercussões econômicas tornam a ajuda financeira a instituições financeiras uma prática mundial. Segundo Goodhart (1995, apud GORTON; HUANG, 2002a, p. 1) dois em cada três bancos, de um universo de 120 distribuídos em 24 países, entre 1980 e 1990, tiveram ajuda financeira. Em outra análise, considerando uma amostra composta de quarenta episódios, Honohan e Klingebiel (2000, apud GORDON; HUANG, 2002a, p.1) concluíram que os países despenderam, em média, 12,8\% de seu PIB para sanear o setor bancário.

Exemplos recentes da existência de canais de comunicação entre tipos de crise foram as da Argentina e do Uruguai analisados por Schmukler et al. (2005).

Crise da Argentina: em 1998, o país era classificado entre os mais sólidos sistemas bancários dos países desenvolvidos. Os bancos eram considerados altamente líquidos, bem capitalizados (a relação média capital/ativos era de 20\%) e contavam com níveis de provisões adequados. A partir de dezembro de 1999, a economia argentina passou a sofrer um forte crescimento de sua dívida em moedas. A moeda local estava sobre-valorizada, o crescimento econômico estava estagnado e havia dificuldade em honrar o serviço da dívida. A situação macroeconômica deteriorou-se rapidamente em 2001 e ocorreram mudanças na condução da política econômica, entre elas, a remoção dos limites para o Banco Central injetar liquidez na economia, que era um dos sustentáculos do currency-board, o que suscitou dúvida quanto à manutenção da paridade peso-dólar. Além disso, o governo, ao invés de procurar reduzir a dívida em moeda estrangeira, passou a absorver a liquidez existente dos bancos e fundos de pensão, aumentando suas exposições a um risco de default. Quando essas fontes de 
financiamento da dívida se esgotaram, surgiu o temor de que o governo passasse a emitir moeda, o que de fato ocorreu, pois o governo passou a emitir títulos de denominação reduzida que, na prática, diferiam apenas formalmente da moeda corrente. A combinação de contração econômica, aumento de risco de default e incerteza sobre a taxa de câmbio levou a uma corrida bancária massiva, gerando uma redução, entre janeiro de 2001 a dezembro de 2001 , de cerca de 50\% dos saldos de depósito a prazo. Ao final de 2001, a corrida precipitou uma crise econômica, que resultou na imposição de limites aos saques bancários (curralito) e a disrupção do sistema de pagamentos. A esses eventos seguiu-se a revolta popular, o default da dívida, o abandono do currency-board, a conversão de depósitos denominados em dólares para peso a uma taxa de câmbio abaixo da praticada no mercado e o alongamento dos prazos dos depósitos.

Crise do Uruguai: após três anos sucessivos de crescimento do PIB acima de 5\% a economia mergulhou em recessão, com queda de 2,8\% do PIB em 1999, devido a diversos fatores, entre eles: a desvalorização da moeda brasileira e a conseqüente perda de competitividade nas relações comerciais com esse parceiro; à dura recessão experimentada pela Argentina; o declínio dos preços mundiais para muitas commodities uruguaias; a apreciação do dólar; ao qual a moeda uruguaia estava atrelada; o aumento dos juros internacionais; e a quebra da produção agrícola. Apesar desse cenário, até 2001, a confiança no sistema bancário não fora abalada. Nesse ano, o saldo de depósitos apresentou crescimento de 12\%, em particular, os depósitos dos não residentes cresceram 34\% fundamentalmente em função da crise na Argentina. Esse "bom contágio" dos depósitos de clientes argentinos tornou-se mau após o congelamento e pesificação ocorrida na Argentina que acabou acarretando demanda de repatriação de depósitos dos clientes argentinos, principalmente, por intermédios das afiliações dos bancos uruguaios na Argentina. Entre dezembro de 2001 e janeiro de 2002, os bancos Galicia Uruguai (BGU) e Banco Comercial perderam 564 milhões de dólares. O governo suspendeu as operações do banco BGU, que operava basicamente com não-residentes, e manteve aberto e capitalizou o Banco Comercial que atendia o público doméstico. Essa diferença de tratamento alimentou a desconfiança dos clientes não-residentes e ajudou a fomentar uma corrida generalizada. Em junho de 2002, o Banco Central abandonou o câmbio fixo e passou a deixar o peso flutuar. A depreciação do peso teve resultado negativo na solvência de diversos bancos, devido à deterioração de seus portfólios denominados em dólar. Um círculo vicioso se instalou: corrida bancária; depleção das reservas do Banco Central e piora do resultado fiscal confluindo para a maior crise 
bancária que o Uruguai já vivenciou. Entre janeiro e julho de 2002, os depósitos a prazo em dólares reduziram-se em 53\% e nenhum banco deixou de sofrer saques.

Schmukler et al (2005, p. 3) avaliam que o risco sistêmico pode afetar os fundamentos dos bancos, prejudicando o exercício da disciplina de mercado, seja por uma efetiva piora gradual desses indicadores, seja pela falta de captura desses indicadores da exposição dos bancos ao risco sistêmico. Um exemplo seria a redução no preço dos títulos do governo em virtude do aumento do risco soberano afetando o resultado das instituições detentoras desses títulos. Outro seria o aumento da inadimplência em virtude de desaceleração da atividade econômica. Um último exemplo seria uma posição dos bancos em dólares e a ocorrência de uma desvalorização cambial. No caso de empréstimos concedidos, mesmo que esses ativos estivessem hedgeados, se os tomadores desses empréstimos não contassem com algum tipo de proteção, poderiam achar-se em dificuldades para pagá-los com claro resultado negativo para os bancos.

\section{Corrida Bancária e Cascatas de Informações}

Dado que se verifique uma longa fila de depositantes com a intenção de resgatar seus recursos, mesmo que ocasionada por uma informação incorreta sobre a saúde financeira do banco, a resposta racional de um depositante desinformado é aderir à fila e resgatar seus recursos antes do que pretendia.

Obviamente, embora o tratamento aqui dispensado seja o do resgate de depósitos, esse comportamento é de natureza social e ocorre em diversas situações. No âmbito do mercado financeiro que, além do resgate de depósitos, analisa o próprio processo de tomada de decisão de investimento, a reversão de planos e adesão a uma ação contrária por parte de investidores racionais e maximizadores de lucro, pode ser explicada por vários motivos. Primeiro, outros podem ter informação privada que é revelada pelas suas ações, por exemplo aderir à fila. Segundo, para administradores de recursos, a imitação é uma forma de preservação, pois a tolerância ao erro individual e localizado é muito menor do que ao erro coletivo. Uma terceira razão seria a busca intrínseca dos indivíduos por conformidade (BIKHCHANDANI; SHARMA, 2001, p. 280).

Diamond e Rajan (2003) estabeleceram um modelo teórico que considera um sistema bancário com um total de depósitos padronizado e igual a 1 , na data 0 . Os depositantes pretendem sacar seus recursos (consumir), na data 1. O banco empresta esses 
recursos a empreendedores com a expectativa de receber $\gamma \mathrm{C}>1$, na data 1 . Na data 0,5 , os depositantes são informados que parte dos empreendedores teve atraso em seus projetos e só poderão pagar aos bancos na data 2. Embora a liquidez agregada do sistema seja insuficiente, $<1$, o percentual dos créditos que não serão pagos na data 1 varia de um banco para outro, permitindo que alguns bancos permaneçam solventes. Os bancos que tem maior percentual de atraso podem obter liquidez ou por meio da venda dos créditos, $\gamma \mathrm{C}$, a serem recebidos na data 2 , mediante um desconto ou reestruturando os empréstimos pendentes. A venda dos créditos só pode ocorrer na data 1, quando os empreendedores em dia, de todo o sistema financeiro, pagarão suas dívidas. A reestruturação, de acordo com o modelo, consiste na recuperação de ativos do empreendedor, abortando o projeto. Esses ativos são transformados em disponibilidades nos montantes $\mathrm{c}_{1}$ imediatamente e $\mathrm{c}_{2}$ na data 2 , sendo $\mathrm{c}_{1}+$ $\mathrm{c}_{2}<1$, ou seja, com perdas. Contudo, como não há liquidez global suficiente, pode-se prever um brusco incremento na taxa de juros, o que tornaria os bancos com maior volume de créditos em atraso, insolventes. Os depositantes, na data 1/2, ao vislumbrarem esse cenário, antecipam-se e resgatam seus recursos dando início a uma corrida bancária contra a instituição. Para atender os depositantes na data $1 / 2$, só resta aos bancos a reestruturação dos créditos, pois a venda só poderia ocorrer na data 1. Essa reestruturação é feita com perdas e atinge todos os créditos, inclusive aqueles que seriam pagos normalmente na data 1. Com esse resultado, diminui a demanda por liquidez do banco insolvente sobre o sistema, que era igual ao volume de depósitos e é liquidada por um valor inferior. Por outro lado, a insolvência acarreta uma redução ainda maior na geração de liquidez, pois o banco reestrutura as operações com os devedores por um valor abaixo do previsto para a data 1 , sendo uma parcela a vista, na data $1 / 2$, e outra a prazo. Essa perda de liquidez pode inclusive acarretar a insolvência de bancos anteriormente avaliados como saudáveis. Esse mecanismo explicaria o efeito contágio oriundo, não de um comportamento irracional, mas sim de uma análise dos fundamentos do sistema bancário.

Uma cascata de informações ocorre quando um indivíduo, tendo observado as ações dos demais à sua frente, reproduz o comportamento dos predecessores independentemente de seu conjunto pessoal de informações (WELCH, 1992, p. 992).

Supondo, por exemplo, que cem investidores possuam avaliações diferentes sobre investimentos em mercados emergentes e que vinte desses investidores tenha expectativas favoráveis sobre esse investimento enquanto os oitenta restantes, não. Se todos os investidores se reunirem e compartilharem suas avaliações individuais, eles, provavelmente, concluiriam que o investimento em mercados emergentes não seria compensador. Se os 
primeiros investidores a tomarem a decisão encontrarem-se entre os vinte otimistas, muitos dos investidores pessimistas (grupo dos oitenta) podem revisar suas expectativas e decidir investir e levar a que boa parte dos cem acabe investindo (BIKHCHANDANI; SHARMA, 2001, p. 280).

Em seu modelo básico, Welch (1992, p. 996) estabelece que, para decidir entre adotar ou não um procedimento, cada indivíduo observa o comportamento dos demais à sua frente. Todos os indivíduos incorrem no mesmo custo de adoção, $\mathrm{C}$, estabelecido em 1/2. $\mathrm{O}$ ganho da adoção, $\mathrm{V}$, é também o mesmo para todos os indivíduos e pode ser 0 ou $1 / 2 \mathrm{com}$ a mesma probabilidade. Cada indivíduo recebe uma sinalização a respeito do valor, que pode ser L (Low) ou H (High), sendo H observado com probabilidade $\mathrm{p}_{\mathrm{i}}>1 / 2$ se o valor verdadeiro for 1 .

De acordo com esse modelo, o primeiro indivíduo adota ou rejeita a ação de acordo com o sinal recebido, $\mathrm{H}$ ou L. O segundo indivíduo pode inferir o sinal recebido pelo primeiro a partir da decisão que ele tomou e confrontar com sua sinalização particular. Se for coincidente, seja $\mathrm{L}$ ou $\mathrm{H}$, ele age de forma idêntica ao primeiro, rejeitando ou aceitando. Caso contrário, a sinalização combinada seria HL ou LH e o indivíduo fica indiferente, podendo adotar ou rejeitar com probabilidade 1/2. O terceiro indivíduo pode deparar-se com três situações: embora seu sinal pessoal seja L, os dois anteriores aceitaram e ele acompanha a decisão gerando uma cascata ascendente; seu sinal é $\mathrm{H}$, e os dois anteriores rejeitaram induzindo-o a acompanhá-los o que gera uma cascata descendente; os indivíduos anteriores tiveram reações opostas, portanto não agregam informação ao terceiro que adota ou rejeita, ou adota de acordo com seu sinal pessoal. Nessa última situação, verifica-se que para o quarto indivíduo, a situação é equivalente à do primeiro e assim por diante, propiciando a geração de uma cascata em qualquer posição da seqüência de indivíduos. Em síntese, o primeiro indivíduo, para o qual o número de indivíduos que adotam superar em dois o dos que rejeitam (ou vice-versa), dá início à cascata. Esse indivíduo, e todos os demais, agindo racionalmente começam a rejeitar suas informações particulares e passam a adotar a cascata. 
As probabilidades relacionadas a cada evento seriam:

A partir do terceiro indivíduo Após um número par $\mathrm{n}$ de indivíduos

$$
\begin{array}{ccc}
\text { Cascata ascendente } & \frac{1-p+p^{2}}{2} & \frac{1-\left(p-p^{2}\right)^{n / 2}}{2} \\
\text { cascata descendente } & \frac{1-p+p^{2}}{2} & \frac{1-\left(p-p^{2}\right)^{n / 2}}{2} \\
\text { sem efeito } & p-p^{2} & \left(p-p^{2}\right)^{n / 2}
\end{array}
$$

Segundo o modelo de Welch (1992, p.1001), mesmo que um indivíduo que esteja bem distante na seqüência prossiga tomando decisões baseadas em seus sinais particulares, as decisões dos indivíduos anteriores transportam alguma informação sobre os sinais deles. Se esse indivíduo estiver bastante distante do início da seqüência, então pela lei dos grandes números, com probabilidade próxima de 1 (quase certeza), ele poderá inferir o verdadeiro valor da adoção. Então, seu sinal particular passará a contribuir muito pouco para sua informação e ele agirá de acordo com aquela inferida das ações dos indivíduos anteriores. Ele passa a ignorar sua informação privada e inicia uma cascata. $\mathrm{O}$ aspecto crucial associado a essa conclusão é que freqüentemente a cascata iniciada é a que conduz à decisão incorreta.

O efeito-manada intencional, aqui analisado, resulta de uma intenção óbvia dos indivíduos em imitar o comportamento dos demais. Esse efeito difere do efeito-manada espúrio considerado aquele onde grupos confrontados com problemas e decisões similares tomam decisões similares. Enquanto o efeito-manada espúrio conduz a um resultado eficiente, o efeito-manada intencional, não necessariamente, é eficiente. Exemplo de um efeito-manada espúrio seria uma venda generalizada de ações ante uma alta de juros, ou seja, a ação coletiva deriva de mudança de fundamentos, que são informações públicas (BIKHCHANDANI; SHARMA, 2001, p. 281).

Welch (1992, p. 1002) avalia também um cenário no qual os indivíduos detêm diferentes precisões na informação obtida, ou seja, dado um valor esperado, a freqüência associada a esse valor é maior para alguns indivíduos que, portanto, contam com uma chance maior de tomar a decisão correta. Além disso, como a sinalização desses indivíduos é mais apurada e existe um custo na demora da tomada de decisão, esses indivíduos tendem a decidir primeiro. Eles servem de modelo para os seguintes, que preferem o sinal inferido da decisão 
tomada pelos detentores de sinal mais apurado em detrimento de seus próprios sinais particulares. O autor conclui que essa situação pode ter efeitos deletérios, pois não existe agregação de informação. Somente replicação da decisão do primeiro que, embora mais acurada, pode estar errada. Seria preferível que a precisão do primeiro indivíduo fosse menor, pois o segundo utilizaria essa informação associada a sua particular, agregando qualidade na informação para os demais.

A conclusão é coerente com estudos sociológicos que demonstram o papel do líder como referência para a tomada de decisão. Quanto mais incerto um indivíduo estiver sobre determinado julgamento, mais suscetível ele estará à influência de informações externas, o que inclui a observação da decisão tomada pelo líder para a sua própria tomada de decisão. Esse aspecto é sobejamente explorado por ações de marketing que procuram identificar produtos a figuras carismáticas ou de expressão pública de modo a transferir a adoção do produto pelo líder para os demais indivíduos da seqüência.

Na visão de Welch (1992, p. 1003), o fato realça a importância da informação para o surgimento da cascata, e por ela surgir mais cedo ou mais tarde. Assim, para entender a causa de uma mudança de comportamento social, torna-se crucial avaliar as ações adotadas pelos líderes iniciais. Um corolário interessante dessa conclusão é que, para se introduzir inovações desejáveis tais como, a melhoria dos hábitos sanitários de comunidades rurais, deve-se procurar persuadir primeiramente os líderes dessa comunidade dos benefícios dessa ação.

$\mathrm{Na}$ verdade, se a informação privada dos agentes individuais fosse tornada pública, poderia se atingir uma decisão mais acurada, por exemplo, do valor de um investimento. Numa cascata de informações esse objetivo poderia ser atingido se o indivíduo, ao invés de adotar a cascata, tomasse a decisão baseado em sua sinalização privada. Após diversos indivíduos terem adotado a mesma postura, haveria um aumento da informação disponível e maior eficiência da tomada de decisão e, portanto, a possibilidade do surgimento da cascata correta.

Outro fator capaz de gerar o efeito-manada é o comportamento não totalmente racional, por exemplo quando se utiliza a estratégia de momento-investimento que representa a tendência do investidor em comprar ou vender ações, baseado na rentabilidade passada das ações, ou seja, comprar ganhadoras recentes $\mathrm{e}$ vender as perdedoras recentes (BIKHCHANDANI; SHARMA, 2001, p.282).

Embora as cascatas de informação, (WELCH, 1992, p. 1004) uma vez iniciadas e acompanhadas da crescente adesão de indivíduos, passem a ter um comportamento mais 
uniforme e robusto, isso não significa que a profundidade da informação transportada não possa aumentar. Novas adesões não agregam informação. Contudo, a chegada de novas informações, mesmo que em pequena quantidade, ou a suspeita, ou a mudança efetiva do valor associado à informação conduzida pela cascata pode induzir à quebra dessa cascata. As cascatas são portanto sensíveis à divulgação de informações públicas.

Essa última observação retrata a importância e responsabilidade na divulgação de informações para o público e realça a responsabilidade dos meios de comunicação e entes públicos para com a sociedade como um todo. $\mathrm{O}$ autor cita por exemplo, a divulgação de estudos médicos que identificaram uma associação entre redução de colesterol e consumo de fibras o que permitiu um aumento substancial desse mercado. Posteriormente, foram divulgados novos estudos contradizendo os anteriores. Em seguida, novas pesquisas indicaram que as fibras são moderadamente eficazes para a redução do colesterol. Outro exemplo emblemático citado pelo autor de surgimento dessas cascatas, também na área médica, foi a prática disseminada de extração das amídalas num passado não tão distante. Verificou-se posteriormente não haver fundamento científico dos benefícios dessa extração e que a prática constituía um simples modismo.

Bikhchandani e Sharma (2001, p. 307) consideram que há sempre assimetria de informações entre tomadores e doadores de recursos, além de algum problema de agência quando os detentores de recursos delegam as decisões de investimento para gestores profissionais. Essa relação sempre possibilitará o surgimento de cascatas de informação e de efeito-manada do tipo reputacional ou baseado em compensações. A divulgação de informações, a disponibilização periódica de dados, e a existência de sistemas de compensação financeira para os gestores mais adequados, podem tornar os mercados e instituições mais transparentes. Ainda mais, o desenvolvimento de mercados futuros pode colaborar para trazer informações a respeito das expectativas de mercado para o domínio público.

Além desse contágio informacional (canal de informação), há também o contágio pelo canal de crédito que deriva das interconexões financeiras entre os bancos que propiciam a transmissão das perdas dos bancos afetados para vários outros (Schoenmaker, 1996, p. 90).

No Relatório de Estabilidade Financeira, encontra-se relato de evento recente de contágio ocorrido na Rússia (BANCO CENTRAL DO BRASIL, 2004, p. 31):

O sistema bancário russo ingressou em um período de instabilidade a partir de maio, quando um banco pequeno, o Sodbiznesbank, teve cassada sua licença para operação por violação de leis relativas à prevenção da lavagem de dinheiro. Em meio a rumores sobre a possibilidade de que 
outros bancos pudessem ser penalizados por práticas similares, o CreditTrust, associado ao Sodbiznesbank, anunciou voluntariamente sua liquidação no início de junho, após corrida por saques em suas contas. Pagamentos de bônus não honrados pelos dois bancos trouxeram pânico ao mercado, provocando a suspensão de linhas de crédito interbancárias, cujas taxas dispararam, afetando sobretudo bancos médios e pequenos. Ao fechamento de mais seis bancos pequenos, seguiu-se a quebra do Guta-Bank, o $22^{\circ}$ maior do país, o qual veio a ser incorporado por um banco estatal. Boatos sobre a insuficiência de liquidez resultaram em corrida por saques no Alfa Bank, o quarto maior banco privado russo, que, mesmo impondo restrições penalizando os saques precisou de significativo aporte de capital por parte de seus acionistas. Para ampliar a liquidez no sistema, o Banco Central reduziu a exigência de reservas bancárias de 7\% para 3,5\% dos depósitos de cada banco. Outra medida implementada foi a extensão a todos o bancos de garantia oficial para depósitos de até 100 mil rublos, aproximadamente US\$3.500. A medida foi retroativa a dezembro de 2003, quando a garantia havia sido instituída favorecendo apenas bancos que atendessem a determinados critérios de solidez financeira.

O Banco Central russo admitiu que o episódio pode fazer parte de um processo natural de consolidação do setor bancário, como resultado da interação das forças de mercado. $\mathrm{O}$ sistema bancário russo é fragmentado, sendo composto por mais de 1.300 bancos, em sua maior parte de pequeno porte com capitalização limitada. O recente episódio demonstrou que a instabilidade originada em bancos pequenos pode ganhar vulto e atingir o sistema bancário como um todo. Porém, essa instabilidade tende a acelerar a implementação de reformas consideradas indispensáveis para aprimorar a regulação bancária, de modo a assegurar a estabilidade financeira.

\subsection{Mecanismos de Mitigação de Crises Bancárias}

\subsection{1}

\section{Requerimento de Reservas e Narrow Banking}

De uma forma genérica, narrow banking é uma proposta de que os depósitos à vista sejam estritamente lastreados por ativos seguros e líquidos. Essa configuração, que teria a finalidade de apartar o processo de crédito do sistema de pagamentos, é conhecida como solução $100 \%$ ou Plano de Chicago por ter sido formulada por membros da Universidade de Chicago, em 1933. A proposta constituía uma resposta à crise dos anos 30 e pretendia que se utilizasse os ativos de todos os bancos membros do Federal Reserve para liquidar os passivos existentes; que, em seguida, se dissolvessem essas instituições e fossem criadas novas que poderiam captar apenas depósitos à vista, destinados a aplicações, na sua totalidade, em reservas no Federal Reserve. Esses bancos seriam destinados apenas para o depósito e transferência de fundos. Por fim, sugeria-se que fossem criadas novas instituições, com formato de fundos de investimentos, que teriam a função específica de fazer a captação e direcionamento dos recursos de poupança.

A adoção desse modelo foi novamente aventada, após as falências maciças de instituições de poupança e empréstimo e a redução das margens das instituições financeiras, provocadas pelo processo de desregulamentação e pelo aumento da competição ocorrida nos

Estados Unidos nos anos 1980. Uma proposta intermediária seria a da criação de holdings 
financeiras que poderiam exercer, por intermédio de subsidiárias distintas, as funções de depositárias de recursos à vista, apoiando-se no seguro depósito, mas com autorização apenas para aplicação desses recursos em ativos de elevada liquidez segregada das funções de investimento e crédito, a partir de recursos que não contariam com o seguro depósito (FERNANDEZ, 1997, p. 22).

Nas estruturas de narrow banking, o seguro depósito teria a função básica de garantir perdas com fraudes, visto que o risco de liquidez é limitado. Embora o potencial de geração de resultado de intermediação financeira dessas instituições seja baixo, deve-se considerar que o risco reduzido implicaria na alocação de um capital substancialmente inferior, o que poderia lhe propiciar uma rentabilidade adequada.

A adoção desse regime resultaria na obtenção de garantia plena para os depósitos à vista, evitando a possibilidade de corrida bancária ou, caso esta ocorresse, garantindo que os resgates seriam integralmente honrados. Em tal regime, as operações de crédito seriam cursadas em um sistema apartado de instituições de crédito, ou então nos mercados de capitais. Os recursos para essas instituições seriam obtidos com a venda de ações ou emissão de debêntures. Como essas instituições não teriam o poder de criar ou destruir dinheiro, elas não demandariam uma supervisão específica (FRIEDMAN, 1959 apud FERNANDEZ; SCHUMACHER, 1997, p. 22). Nesse arranjo, o risco de crédito seria retirado do sistema financeiro que ficaria protegido, assim como o próprio sistema de pagamentos, das incertezas do mercado de crédito.

Fernandez e Schumacher (1997, p. 26), em sua análise sobre o impacto da propagação da crise do México no sistema financeiro da Argentina, ocorrida em final de 1994, relacionam os seguintes mecanismos que atuaram como amortecedores do choque:

- A boa capitalização dos bancos foi um dos fatores que contribuiu para a minimização das conseqüências. Naquele momento, a relação capital/ativos média do sistema financeiro era de $13,4 \%$ e, considerando a ponderação dos ativos pelo risco, essa relação atingia $18,2 \%$;

- Havia cerca de $\$ 9,4$ bilhões de pesos em reservas líquidas no Banco Central, que representava aproximadamente $20 \%$ do total de depósitos, o que ajudou a compensar a perda de depósitos no período de pânico e a minimizar a redução no crédito e nas perdas bancárias;

Ao final de maio de 1995 a perda total de depósitos era de \$8 bilhões de pesos, cerca de $18 \%$ dos depósitos. Desse total, $\$ 3,4$ bilhões de pesos foram compensados pela liberação de reservas; $\$ 2,3$ bilhões de pesos por meio de operações compromissadas e empréstimos do Banco Central; e \$1 bilhão de pesos correspondeu à redução das carteiras de 
crédito. Ou seja, $41 \%$ da redução foi compensada com reservas compulsórias e apenas 13\% dessa perda foi suprida por redução de empréstimos dos bancos o que representou uma redução de 2,3\% no saldo de operações de crédito do sistema financeiro em dez.1994.

A administração da crise permitiu avaliar que, embora as reservas compulsórias tenham permitido ao Banco Central combater a crise, elas afetam o custo do crédito. Em vista disso, decidiu-se preservar o total de liquidez do sistema minimizando, porém, os custos envolvidos por meio da autorização para que os bancos investissem essas reservas em ativos de baixo risco, tais como títulos dos países da OECD ou operações compromissadas como o próprio Banco Central. Além disso, os requerimentos de reservas foram substituídos por requerimentos de liquidez, e taxas uniformes foram estabelecidas para contas correntes e depósitos a prazo.

A constatação de que bancos que detinham baixa parcela de captação de depósitos (em geral bancos de atacado) sofreram saques maiores indicou que a contribuição de cada banco para a liquidez do sistema deveria depender do total de obrigações e não apenas dos depósitos. Em vista disso, os bancos passaram a serem obrigados a investir uma parcela de seus passivos (5 a 15\%, a depender da maturidade) em ativos livres de risco. Foram implementadas também novas regras para a divulgação de informações, inclusive com a determinação de que os bancos publicassem avaliações de risco de uma ou duas agências de risco, independentes e de que fossem divulgadas as taxas praticadas para diferentes tipos de depósitos. Por fim, foi atribuído maior poder ao Banco Central para impor penalidades.

Segundo Fernandez e Schumacher (1996, p. 28), entre nov. 1994 e mar. 1995, 3.490 grandes depositantes remeteram recursos no valor total de $\$ 3$ bilhões de pesos para o exterior, representando $90 \%$ dos saques em depósitos a prazo e $64 \%$ dos saques totais. Verifica-se, portanto, que os depósitos à vista e depósitos a prazo de menor denominação, conjuntamente com as reservas compulsórias contribuíram para a manutenção da normalidade do sistema. Em um arranjo do tipo narrow banking, essa assimetria de informações é praticamente toda removida. Os pequenos depositantes e os depositantes avessos ao risco, que não podem bancar o custo de aquisição de informação, passam a contar com um contrato financeiro que tem um retorno certo. Da mesma forma, clientes melhor informados ou clientes institucionais podem optar por contratos no mercado de capitais que ofereçam melhores retornos, porém com maior volatilidade. Numa estrutura de narrow banking a eventual insolvência de uma instituição de crédito, não bancária, não demandaria qualquer ação do Banco Central, pois não haveria o risco de contágio. Na verdade, o próprio 
mercado de crédito deveria fornecer incentivos para que essas instituições evitassem assumir riscos exagerados.

Gerard Caprio Jr. (WORLD BANK, 1997, p. 32), considera que a adoção de um sistema de narrow banking implicaria num rebaixamento da rentabilidade dos depósitos. Essa conseqüência, tal como ocorreu nos Estados Unidos em 1994, quando as taxas de juros atingiram os menores níveis em 30 anos, estimularia a migração de recursos para aplicações mais rentáveis e de maior risco. A depender do volume de recursos que migrassem e de o governo se sentir impelido a prover garantia para esses recursos, não haveria nenhum ganho com a mudança que se limitaria a uma alteração de nomenclatura do sistema financeiro. Nesse aspecto, embora a idéia da adoção de narrow banking seja a atrativa, cabe avaliar que tipo de atitude o governo teria nos casos de insolvência de instituições não bancária maiores e de grande influência política. Se um sistema de garantias migrar junto com os recursos para o sistema não bancário, uma porção substancial do sistema financeiro ficaria sem supervisão. $\mathrm{O}$ governo rapidamente perceberia que, para se prover uma malha de segurança haveria necessidade de supervisão e, se a supervisão passasse a ser necessária, um dos principais atrativos da idéia de narrow banking desapareceria.

Outras alternativas para a prevenção de crise bancária existem e precisariam ser melhor avaliadas, tais como: assegurar a responsabilidade solidária entre os bancos; elevar o capital mínimo exigível; aumentar os limites das responsabilidades dos proprietários dos bancos ou o próprio valor das franquias; determinar que os bancos emitam grandes volumes de dívida subordinada, não segurada. Essas alternativas teriam a vantagem de preservar a sinergia entre a captação e empréstimo dos recursos, cuja perda é uma das razões de crítica ao conceito de narrow banking (Ibid., p. 32).

Beck (2003, p. 10) acrescenta que um aumento de disciplina poderia ser atingido imputando-se as perdas primeiro aos acionistas controladores e responsabilizando-os por perdas acima do capital investido. A dívida subordinada seria outra forma de imposição de maior disciplina, utilizando-se uma classe de credores de baixa prioridade para o resgate de recursos, portanto com maior incentivo para monitorar as operações dos bancos.

George J. Benston (WORLD BANK, 1997, p. 35) aponta alguns pontos desfavoráveis para a adoção do narrow banking:

- Perda dos benefícios para que os clientes possam aplicar os recursos e adquirir empréstimos em uma mesma instituição, o que inclui a economia de custos para obter e fornecer informações para os tomadores de empréstimos; 
- A centralização de operações de depósito, de crédito e de investimento em uma única conta corrente acarreta economias de custos de transação e reduz a complexidade da administração dos fluxos de recursos;

- Qualquer banco nos Estados Unidos pode estruturar-se de acordo com um modelo de narrow banking. Eles não são obrigados a prover empréstimos. O fato de nenhum banco ter adotado essa configuração parece indicar que a conciliação das atividades de captação e de empréstimos é mais atrativa;

- O seguro-depósito propicia o mesmo tipo de proteção atribuída ao narrow banking. $\mathrm{O}$ diferencial, em princípio, seria apenas o custo direto;

- Como, pela própria característica desse tipo de arranjo financeiro, a remuneração dos bancos seria reduzida, a rentabilidade desses mesmos teria que ser compensada por meio da cobrança de tarifas dos depositantes;

- A estrutura de narrow banking eliminaria o risco apenas das instituições depositárias e do sistema de pagamentos. As instituições não bancárias continuariam submetidas a esse risco e, provavelmente, teriam que ser socorridas pelo banco central.

Fernando de Santibañes (WORLD BANK, 1997, p. 40), ao analisar a mencionada resiliência do sistema financeiro argentino na crise do México, considera que o amortecimento do impacto só foi possível pela estrutura bancária vigente, pois os resgates de depósitos foram atendidos pelas reservas disponíveis. Num esquema de narrow banking, o impacto de resgates nas carteiras de crédito no sistema não bancário seria direto.

\subsubsection{Seguro-Depósito}

Em 1980, somente dezesseis países contavam com o mecanismo de seguro-depósito. Em 1999, o número de países adotantes chegou a 68. (GARCIA, 1999, apud GORTON; HUANG, 2002b).

Sjaastad (1996, p. 47) pondera que a instabilidade de um sistema bancário que conta com reserva fracionária deriva de uma externalidade sobejamente conhecida: o resgate de um depósito reduz a liquidez dos depósitos remanescentes.

O seguro-depósito e o empréstimo de liquidez proporcionado pelo Banco Central, são formas complementares de promover estabilidade ao sistema financeiro. O primeiro busca reduzir o risco de corrida bancária e é utilizado apenas em caso de insolvência da 
instituição. O segundo pretende prover liquidez ao sistema em situações específicas. (Ibid., p.47)

O seguro-depósito, na visão de Sjaastad (1996, p. 48), não reduz as perdas reais da sociedade oriundas de investimentos inadequados. Ele apenas promove redistribuição dessas perdas, eventualmente, com toda a sociedade. Seu maior benefício resulta do aspecto mitigador de corridas aos bancos. Esse objetivo, a depender do limite de proteção fornecido, acaba possibilitando o efeito adverso de risco moral. Como o depositante sabe que conta com uma proteção, ele perde o incentivo em monitorar a instituição, e por conseguinte, a aplicação dos recursos. Essa característica é realçada, se comparada a outros tipos de seguro, como contra roubo de automóvel ou incêndio de residência, na medida em que o grau de transtorno para o segurado é bem menor do que seria no caso de ter o automóvel roubado ou a casa incendiada.

A ausência de um seguro-depósito pode ser fator de encorajamento para os grandes depositantes ou credores monitorarem os bancos e exercerem a disciplina de mercado, reduzindo assim o apetite ao risco dos bancos e, por conseguinte, o risco de fragilidade financeira (BECK, 2003, p. 2).

A crise Argentina de 1980, na visão de Beck, é um exemplo de situação em que o seguro-depósito conduziu a ocorrência de elevado nível de risco moral. Naquele momento, enquanto o seguro-depósito estava em fase final de eliminação, três grandes bancos chegaram à situação de colapso iminente. Para tratar da crise, o seguro-depósito foi rapidamente reinstalado com previsão de cobrir não só o principal como também os juros. Além disso, o ressarcimento pelo Banco Central foi imediato. O resultado desse procedimento foi que os depositantes passaram a procurar instituições que pagavam maiores juros, portanto maiores riscos. O mesmo procedimento foi adotado na crise das instituições de poupança e empréstimos do mercado americano, ou em 1984, na quebra do banco Continental de Chicago. A questão passa a ser de credibilidade. Seria possível para um governo praticar uma política na qual não existiria o seguro-depósito, ou o público iria considerar que existiria uma garantia implícita, ao menos em relação aos grandes bancos, "too big to fail" fenômeno. O desenho de qualquer seguro depósito deveria contemplar as seguintes características:

- O oferecimento do seguro-depósito deveria abranger apenas as instituições que atendessem requisitos mínimos de capital e de reservas e, até, de qualificação de seus diretores;

- O prêmio cobrado do seguro deveria ser definido de acordo com o risco da instituição e portfolios de elevado risco não deveriam ser cobertos; 
- Deve haver teto de cobertura para reduzir o risco moral;

- O seguro de cunho governamental deve contar com um sistema efetivo de regulação e supervisão das instituições seguradas. Os administradores dessas instituições devem ser sujeitos à imputação de responsabilidade em relação ao exercício dos cargos.

- As instituições insolventes deveriam ser liquidadas, nunca absorvidas por outras, para evitar o efeito exemplo;

- Para atenuar o risco moral, os controladores majoritários também devem ser alcançados pela imputação de responsabilidade acima daquela que é limitada e definida na legislação societária;

- Para reduzir ainda mais o risco moral, o contrato de seguro deve contar com cláusulas estritas prevendo a desobrigação total ou parcial do segurador nos casos em que se descubra que a instituição realizou práticas ilegais (por exemplo, falsificação de documentos) ou deliberadamente sonegou informações do órgão supervisor.

Uma das possíveis configurações de sistema de seguro-depósito que minimizasse o risco moral seria a de estabelecer um limite de cobertura, definindo-se uma margem de perda que estimulasse um conjunto de clientes com potencial para exercer a disciplina de mercado a efetivamente exercê-la (BECK, 2003, p. 5). Outro aspecto importante diz respeito à administração desse fundo garantidor de créditos. Uma administração composta pelos próprios bancos poderia reduzir o incentivo à tomada de risco. Os bancos não só possuem a capacidade de monitorar-se mutuamente, mas também teriam fortes incentivos para evitar as perdas desse seguro, visto que eles teriam que suportar essas perdas.

Paul M. Horvitz (WORLD BANK, 1996, p. 52) considera que o aumento dos requerimentos de capital representa um fator de mitigação de risco moral. Porém, esse instrumento, destinado a limitar o comportamento de alto risco do acionista, só terá eficácia se for complementado por um sistema de supervisão efetivo que monitore ativos e passivos tendo em vista valor de mercado e que permita uma intervenção antes que o patrimônio líquido do banco reduza-se a zero. Horvitz discorda quanto a restringir a fusão ou a incorporação do banco insolvente. Segundo ele, importa que os antigos controladores e administradores, responsáveis por provocar a situação de insolvência, sejam removidos. Discorda também em relação ao estabelecimento de prêmios de risco para o seguro, com base no risco dos portfolios. Na sua visão, o monitoramento é muito mais importante. Se os ativos puderem ser corretamente avaliados, então a fraude torna-se o risco mais importante a ser monitorado. 
Brooks (1996) avalia que o seguro-depósito pode estimular a assunção de risco excessivo, pois os banqueiros contam com recursos que podem ser aplicados em apostas enviesadas. Se eles ganham, retém os lucros, se perdem o governo paga a dívida. Nesse caso, a garantia funciona como uma opção de venda. Se o valor dos ativos fica abaixo do valor dos passivos a garantia complementa a diferença. Dessa forma, o aumento do risco, ou volatilidade, acarreta, tal qual numa opção de venda, um aumento no valor da garantia. Uma forma de contra-balançar esse estimulo à aposta de risco seria o de elevar o valor da franquia, por exemplo aumentando o capital mínimo requerido. Quando um banco tem um valor de franquia positiva e um balanço saudável, o valor da garantia para o banqueiro é baixo. Porém, se o valor da franquia estiver erodido, até mesmo pequenas deteriorações posteriores do balanço podem incentivar a adoção de estratégias de risco.

Demirguç-Kunt e Detragiache (2000) efetuaram trabalho empírico construindo 898 indicadores de situações de crise sistêmica ou de problemas no setor bancário, abrangendo 61 países, no período de 1980 a 1997. Cerca de metade desses países contava com algum tipo de seguro-depósito. Sua conclusão é que a existência do seguro-depósito pode ser permissiva principalmente nas economias que passaram por um processo recente de desregulamentação dos juros bancários e nas quais o ambiente institucional é frágil. Uma interpretação correlata é que nos países que contam com um ambiente institucional adequado, é mais provável que exista um aparato regulador e de supervisão eficiente que contrabalançaria uma falta de disciplina de mercado induzida pela existência do seguro-depósito. Além disso, o impacto adverso do seguro depósito tende a ser maior, quanto maior a sua cobertura e se o seguro for de responsabilidade do governo e, ainda, se ele contar com fundo garantidor específico. Os autores concluíram que nos países que contam com o seguro-depósito os juros são, em geral, mais baixos e menos sensíveis aos fatores de risco específicos dos bancos o que reforçaria o argumento de um enfraquecimento do monitoramento das instituições pelos depositantes.

Segundo Beck (2003, p. 6), um sistema de garantia de depósitos deveria dispor e demonstrar a existência de fundos suficientes para assegurar seu potencial de cobertura. Mesmo que esses recursos não estivessem disponíveis, o sistema deveria contar com fontes de financiamento asseguradas, até mesmo, públicas, que seriam ressarcidas pela indústria bancária, no período posterior à crise. Além disso, o sistema deveria contar com a participação do segurador ou provedor de recursos para o seguro, na regulação e supervisão dos bancos segurados, o que incluiria:

- Participação no processo de licenciamento das instituições; 
- $\mathrm{O}$ direito a requisitar auditorias específicas em bancos considerados pelos demais membros como frágeis;

- O poder de excluir bancos avaliados como de gestão temerária ou inadequada. Esse item, o próprio autor considera de difícil aplicação e que teria apenas efeito inibidor.

Os mecanismos de seguro-depósito existentes variam desde a configuração como simples agência pagadora de seguros, como é o caso do Brasil; até configurações nas quais, à função de seguradora, é associado o exercício de supervisão e resolução de falências, como no caso americano. Em outros esquemas, como o da Alemanha, embora os seguradores tenham poder restrito, na prática seu potencial de atuação é bem mais amplo (BECK, 2003, p. 14). O autor relata as principais características do seguro de três países:

- Alemanha: O mercado bancário é composto por três setores principais: bancos de poupança de propriedade de estados, municípios e condados; bancos privados; e bancos cooperativos. Os bancos de poupança e cooperativos possuem seguros regionais e um sistema de compensação nacional. O sistema para os bancos privados é voluntário e com elevada cobertura dos depósitos de clientes não financeiros. Não há co-seguro e apenas depósitos interbancários, títulos ao portador e contas de pessoas ligadas não são cobertas. $\mathrm{O}$ financiamento e a gestão são totalmente privados e os bancos pagam um prêmio de $0,03 \%$ ao ano, com prêmios maiores para bancos que são avaliados com maior nível de risco. A avaliação de risco é conduzida pela Auditing Association pertencente à German Bank Association. O poder regulatório e de supervisão entre os membros é elevado e a Associação emite opinião ao órgão supervisor sobre a emissão de licenças de operação para novos bancos. A Auditing Association impõe medidas corretivas aos membros nos casos de incremento de risco ou violações de regulamentação. Finalmente, os membros podem ser expulsos do sistema nos casos de prestação de informações incorretas ou se estiverem classificados no pior nível de risco por dois anos consecutivos. A intervenção em bancos insolventes é feita conjuntamente pelo órgão supervisor e os bancos. Essa associação demonstra-se interessante a partir de exemplos como o da intervenção no banco Munchmeyer, Hengst and Co (SMH) cujos problemas foram descobertos pela German Bank Association e não pelo órgão supervisor.

- Brasil: A falência de diversos bancos privados de grande porte, nos anos 1990, foi resolvida utilizando-se o modelo bom-banco-mau-banco, com o Banco Central fornecendo recursos para financiar o déficit. Na esteira dessa crise a regulação bancária foi fortalecida e a supervisão bancária significativamente melhorada. No caso brasileiro, o 
Banco Central respondia pelos quatro pilares da rede de proteção financeira: regulação e supervisão, resolução das situações de falência bancária, emprestador de última instância e garantidor de depósitos. Com a proibição instituída pela constituição de 1988 de se utilizar recursos públicos para proteger os depositantes, foi criado o Fundo Garantidor de Créditos (FGC) que contém características de incentivos compatíveis com padrões preconizados para a indústria. Abrange todos os depósitos, possui uma cobertura baixa, não há co-seguro, os depósitos interbancários não são cobertos; o seguro é financiado por prêmios pagos pelos bancos ( $0,3 \%$ a.a. do saldo de depósitos) e não há aporte de recursos públicos. Seu papel limita-se ao de agente pagador, pois não interfere com a supervisão ou resolução das falências bancárias. A ação em relação aos bancos problemáticos é conduzida em um processo extrajudicial, com liquidantes e interventores indicados pelo Banco Central do Brasil. Embora o processo extra-judicial pretendesse se beneficiar da qualificação do Banco Central em relação ao sistema financeiro e evitar a lentidão e ineficiência do processo judicial os resultados têm sido desapontadores. As liquidações são demoradas visto que os liquidantes, além de não terem nenhum incentivo para terminar o processo de forma rápida, sujeitam-se à responsabilidade jurídica por qualquer ação tomada no curso da liquidação. $\mathrm{O}$ curso normal das liquidações é também prejudicado por intervenções jurídicas em resposta a questionamentos dos controladores ou partes interessadas. Outra questão prejudicial é que, dada a prioridade ilimitada atribuída a obrigações tributárias e trabalhistas, os demais credores não vêem nenhum incentivo em pressionar pela agilização do processo de liquidação. Dessa forma, a maioria dos bancos que atinge a insolvência, acaba sendo liquidada, resultando em deperecimento de ativos e destruição das relações creditícias. O sistema não é suficientemente amarrado ao restante da rede de segurança bancária, devido às deficiências do sistema de resolução de falências e carece de uma maior participação das instituições bancárias, seja para emitir parecer sobre novos licenciamentos, requisitar auditorias extraordinárias em bancos com sinais de fragilidade, seja para poder excluir membros que exerçam gestão inadequada.

- Rússia: O sistema bancário russo sofreu um grande revés, na crise de 1998, graças à reestruturação unilateral da dívida do país, ao colapso do sistema de pagamentos e às corridas bancárias. Como não havia o seguro bancário, grande parte dos depositantes foi protegida pela transferência de seus haveres dos bancos privados para o banco governamental Sberbank. Atualmente esse banco detém uma participação de $75 \%$ do varejo de depósitos e $25 \%$ dos ativos totais do sistema. A crise de 1998 revelou significantes fragilidades na regulação e supervisão bancária e a resposta a ela limitou-se a um 
relaxamento das normas e fornecimento de liquidez a bancos selecionados, sem a divulgação dos critérios que conduziram a essa seleção. Embora essa atuação pretendesse aliviar a pressão sobre os bancos, ela possibilitou aos controladores vender ativos e facilitou a fuga de capital. O duplo papel do banco central, de proprietário e regulador de dois grandes bancos problemáticos, Sberbank e Vneshtorgbank suscita, inevitavelmente, a questão do conflito de interesses. A agência ARCO, especialmente criada para dar solução aos bancos insolventes, tem uma ação dúbia. Muitos bancos que sofreram intervenção permaneceram abertos, inclusive com a manutenção dos administradores e controladores, e em outros, o processo de liquidação tem sido extremamente lento. Embora o banco central tenha a responsabilidade de cuidar da intervenção e liquidação dos bancos problemáticos, excetuando-se aqueles sob administração da agência $\mathrm{ARCO}$, os bancos não vêm sendo adequadamente supervisionados ou os administradores punidos nos casos de falência. Intervenção tardia, liquidação lenta e reembolso aos acionistas e grandes credores criam incentivos perversos. O governo russo pretende, como forma de aumentar a confiança em seu sistema financeiro, introduzir um sistema de seguro-depósito num futuro próximo. $\mathrm{O}$ seguro será financiado com recursos públicos e dos bancos $(0,6 \%$ do saldo dos depósitos cobertos), sob administração pública e terá somente o papel de caixa pagadora, sem qualquer participação dos bancos privados. O esquema possui elevado potencial para encorajar posturas agressivas e imprudentes dos bancos, porque precisa ter o suporte de um sistema de supervisão, de regulação e de disciplina de mercado eficiente.

Gupta et. al. (2000, p. 22), analisando diversas crises bancárias, verificaram que o aumento das taxas de empréstimos e do spread dos bancos nos períodos de crise não é seguido de um aumento nas taxas de remuneração dos depósitos. Uma interpretação plausível para esse fato é que a rede de proteção bancária existente foi bem sucedida em garantir a manutenção dos depósitos apesar de haver uma relevante insolvência no sistema bancário. Outra constatação desse estudo é que a redução nos saldos dos depósitos à vista é maior nos países que não contam com o seguro-depósito.

\subsubsection{Regulação e Disciplina de Mercado}

O papel governamental de regulador e de supervisor do sistema bancário é freqüentemente definido como a responsabilidade de controlar a exposição ao risco dos bancos bem como para exercer um monitoramento adequado do sistema bancário, pois conta 
com uma vantagem comparativa em recolher e aglutinar informações. Essa responsabilidade decorre da existência de uma rede de segurança financeira formada: pelo seguro-depósito; pelo empréstimo de última instância; por garantias relativas ao sistema de pagamentos que torna o governo um detentor potencial dos passivos bancários; e pela crença generalizada de que as falências bancárias podem ocasionar conseqüências severas para o sistema financeiro (BERGER et. al., 1998, p. 2).

Um dos elementos principais, que impõe a necessidade de regulação estrita no sistema financeiro, é a possibilidade de ocorrência de fraude em grande escala. As perdas maciças sofridas pelo Banco de Intercambio Regional na Argentina no início dos anos 1980 e, mais recentemente, pelo Banco Econômico no Brasil e Banco Latino na Venezuela, denotam o potencial deletério da ocorrência de fraudes (WORLD BANK, 1997, p. 2).

É consenso geral que as falências bancárias diferem do colapso de outras firmas pelo potencial de prejuízo que podem acarretar ao sistema de pagamentos, pelo fato de emprestarem recursos tomados de terceiros (poupança popular) e pela própria assimetria de informações - os bancos não dispõem de todas as informações sobre os tomadores; e os depositantes, por sua vez, detêm poucas informações sobre os créditos concedidos.

O surgimento dos bancos centrais é um fenômeno do século XX. No início desse século, havia somente dezoito bancos centrais; em 1951, esse número era de 59 e, em 1990, alcançava o total de 161 (CAPIE, 1997 apud GORTON; HUANG, 2002b, p. 1).

Schoenmaker (1996, p. 1) considera que a necessidade da regulação e supervisão bancária depende, essencialmente, da existência ou não do risco de contágio no sistema bancário. Contágio aqui entendido como o risco de que as dificuldades financeiras de um banco possam se propagar para um grande número de outros bancos ou até para o sistema bancário como um todo.

Os defensores da desregulamentação do setor bancário, embora concordem com o risco potencial de ocorrer uma ruptura do mercado, consideram que a intervenção pública e a regulamentação conduzem a uma ineficiência na alocação de recursos, devido às dificuldades intrínsecas associadas a uma regulação eficiente (SLOVIN et. al., 1999, p. 199).

Segundo Schoenmaker (1996, p. 87), o advento dos bancos centrais desempenhando a função de emprestadores de última instância para prevenir insolvências e a possibilidade de contágio do sistema acarretou uma redução nos eventos de contágios, o que deve ser levado em consideração nas análises do fenômeno. A observação reveste-se de importância na medida que, após a confirmação de que o risco de contágio é real, justifica-se a presença do governo para prover assistência financeira ao setor nos momentos de crise e para prevenir a 
seleção adversa ou o risco moral associado a essa intervenção com recursos públicos. Tornase necessário então a imposição de regulação e supervisão específica. Nesse contexto, a baixa ocorrência de corridas bancárias seria um indicativo da eficiência da atuação dos bancos centrais.

Gorton e Huang (2002b, p. 32) comparando a eficiência de um sistema de proteção bancária privado, formado por uma coalizão de bancos, com um sistema público, concluíram que, numa situação de pânico, a disrupção do sistema de pagamentos acarreta perdas econômicas, ou redução do bem estar social, que não seriam devidamente consideradas por um sistema privado de proteção. Essa seria uma justificativa adicional para sua execução pelo governo.

Intervenções que propiciem uma maior demanda por liquidez no sistema, como por exemplo, a prestação de garantias a bancos ilíquidos que passam a poder buscar novamente recursos no mercado, podem acarretar pressão sobre a liquidez disponível com conseqüências sobre as taxas de juros e, eventualmente, prejudicar outras instituições anteriormente saudáveis. Uma intervenção inapropriada pode desestabilizar um sistema que tenderia ao equilíbrio, mesmo que ao custo de algumas insolvências. (DIAMOND; RAJAN, 2002, p. $38)$.

Gorton e Huang (2002a), partindo de análise teórica, consideram que a manutenção de liquidez pelos agentes privados com o intuito de aproveitar oportunidades do mercado de crédito, ou seja, adquirindo créditos com desconto, pode ser sub-ótima, o que justificaria um papel do governo como provedor de ajuda financeira aos bancos em dificuldades. Essa ajuda seria mais eficiente quando houvesse a possibilidade de surgimento de risco moral ou maior propensão à assunção de risco pelos bancos em virtude de inadimplência exagerada. Essa busca por maior retorno pode decorrer: da contratação de operações com clientes de maior risco; da adoção de uma postura de maior tolerância e cumplicidade com operações em andamento, que não apresentam perspectivas de recuperação; ou até, da recusa em renegociar as dívidas vencidas, para não ter que reconhecer as perdas, o que pode induzir os devedores à adoção de estratégias de maior risco. Por outro lado, tanto a negociação freqüente pelos bancos quanto a ajuda financeira governamental podem propiciar o surgimento do risco moral já na contratação do crédito

O elevado custo da regulação prudencial, que inclui barreiras de entrada, exigências de capital, imposição de sistemas de avaliação de risco de crédito, existência de agência regulatória e supervisora bem como o próprio seguro-depósito, tem incentivado a busca de soluções alternativas tais como, a regulação (disciplina) de mercado segundo Rolf J. Luders 
(WORLD BANK, 1997, p. 70). Nessa abordagem o seguro-depósito subsidiado seria eliminado e as instituições financeiras passariam a ser obrigadas a divulgar ao público informações normalmente disponíveis apenas para os reguladores. Nessa concepção, os depositantes assim como acionistas assumiriam as perdas quando essas superassem o patrimônio líquido.

Outra característica que merece avaliação é a discricionariedade atribuída ao supervisor bancário para avaliar a seriedade dos problemas das instituições e determinar as ações corretivas necessárias. Para a tomada de decisão, o supervisor depende de uma análise julgamental que leva em consideração diversos fatores, tais como: extensão territorial da atuação do banco, tipo e volume de empréstimos concedidos, volume de negócios com derivativos e outras transações fora do balanço e envolvimento em negócios globais. Dessa análise, acaba resultando que bancos grandes e complexos possuem um potencial maior para gerar um efeito contágio sugerindo, por conseguinte, um tratamento diferenciado o que seria plenamente justificado. Outra forma de visualizar o mesmo fato seria sob a ótica de teoria da captura da regulação. Segundo ela, o regulador ficaria cativo desse segmento bancário o que implicaria num subsídio implícito para atividades de maior risco. Como resultado, os reguladores tornam-se passivos e cooperativos ao tratar de grandes bancos e aliam-se aos administradores na esperança de recuperar a solvência, ao invés de perseguir os interesses dos depositantes e contribuintes, reconhecendo o problema e atuando diretamente nele (SLOVIN et. al, 1999, p. 203).

Exemplo dessa discricionariedade de atuação ocorreu na ajuda ao banco americano Continental Illinois, que estava insolvente. Os reguladores consideraram que o benefício para a economia em termos de redução do risco sistêmico suplantava o custo da extensão da cobertura para todos os depositantes. (WALL; PETERSON, 1990, p. 78).

Schoenmaker (1996, p. 91) considerou que o risco, no caso do Continental Illinois, foi o da transmissão pelo canal de crédito, pois ele contava com uma grande rede de bancos correspondentes e detinha depósitos de cerca de mil bancos, sendo que 65 desses bancos tinham depósitos não cobertos por garantia que excediam 100\% dos respectivos capitais e outros 113 detinham depósitos que representavam entre 50 a 100\% de seus capitais. Contudo, a perda efetiva não deveria ser elevada se o fechamento da instituição fosse conduzido de forma suave, pois não seria de se esperar que os ativos tivessem uma brusca perda de valor. Todavia, as incertezas sobre o tamanho das perdas e sobre o tempo necessário para reaver os recursos investidos poderia ter gerado uma corrida bancária que daria início a uma cadeia de insolvências bancárias. 
Wall e Peterson (1990, p. 98) avaliam que no período entre os anos 1930 e 1970 as perdas devido ao pagamento de seguro-depósito no mercado americano foram tão reduzidas que justificariam qualquer redução no risco de ocorrência de corridas bancárias. Contudo, esse custo vem subindo substancialmente nos anos recentes o que justificaria uma reavaliação dos riscos de corridas bancárias. Utilizaram a metodologia de estudo de eventos, comparando os retornos anormais em bancos selecionados, em relação a fatos e notícias relevantes sobre a insolvência e posterior ajuda financeira ao banco Continental Illinois. Acharam, apesar da assertiva dos reguladores de que o auxílio era necessário, fraca evidência de que esse auxílio era necessário e evidência consistente de que a ajuda enfraquece o exercício da disciplina de mercado.

Outra ferramenta importante para prover maior estabilidade ao sistema bancário e reduzir o custo das falências é a existência de regras e procedimentos claros de retirada. Regras claras que prevejam a intervenção imediata e a perda completa do patrimônio, nos casos de insolvência resultariam em posturas mais conservadoras dos administradores (BECK, 2003, p.8). Essa intervenção deveria contemplar duas características básicas: a possibilidade de os depositantes resgatarem seus recursos, evitando-se o espraiamento da crise e a pressão sobre o resto do sistema bancário; e que os empréstimos ativos fossem mantidos no sistema financeiro, e não liquidados imediatamente. Esta última, destinada a assegurar a disciplina dos devedores e a manter seu acesso ao crédito bem como o valor da informação sobre os clientes e operações de crédito em andamento.

Beck (2003, p. 10) avalia ainda que a intervenção bancária deveria ser exercida pelo agente que tivesse os maiores incentivos para minimizar as perdas, no caso o supervisor bancário, pois ele tem o melhor conjunto de informações para atuar tempestivamente e sanar a situação de bancos com problemas. Contudo, os supervisores nem sempre contam com bons incentivos para intervir, pelo contrário, às vezes procuram protelar essa decisão até o final de seus mandatos (KANE, 1990 apud BECK, 2003, p. 11). Pressões políticas e restrições de cunho regulatório, assim como a possibilidade de imputação de responsabilidade pessoal, podem ser fatores inibidores da atuação desses supervisores.

Boot e Thakor (1993 apud SLOVIN et. al., 1999, p. 205) corroboram essa opinião ao considerar que um regulador zeloso de preservar sua reputação tem um incentivo por adiar sua atuação além do que seria considerado ótimo do ponto de vista social. O servidor público com preocupações em relação a sua carreira e reputação pode enxergar a intervenção na gestão de um banco como uma admissão de falha no monitoramento apropriado. 
Berger et. al. (1998, p. 6) apontam uma diversidade de enfoque na avaliação da higidez das instituições bancárias. O supervisor bancário age tanto para proteger as posições detidas, representadas pelas contingências potenciais sobre a rede de segurança financeira, quanto para prevenir crises sistêmicas. Nessa forma de atuação, sua principal preocupação é com a probabilidade e com a severidade de eventuais falências bancárias. Da mesma forma, as agências classificadoras de bancos e de dívidas preocupam-se com as perdas potenciais decorrentes de eventos adversos. Em contraste, os acionistas e investidores têm uma menor preocupação com o risco e estão mais interessados no potencial de resultados positivos, isto é, no fluxo de caixa esperado sem levar em conta a possibilidade de ocorrência de insolvência.

Já a idéia de disciplina de mercado pode ser entendida no contexto do conflito agente-principal. O principal (depositante) deseja assegurar que o agente (gestor do banco) proteja seus ativos. Assim, o depositante responde ao aumento do risco no banco, requerendo maior rentabilidade sobre seus depósitos ou sacando seus recursos. Essa ação, por sua vez, penaliza o administrador pela assunção de risco excessivo o que representa um balizador para a gestão do risco. A existência de disciplina de mercado conduz a uma redução da probabilidade de falências e de crises bancárias, resultando em um sistema bancário mais saudável (SCHMUKLER et al,2005, p. 1). Em situações de risco sistêmico, o problema de agência pode até evoluir para um problema de agência dual, se o governo se inserir como um segundo agente a interferir na gestão das instituições e mesmo, direta ou indiretamente, em contratos privados. Por exemplo, em situações de crise de liquidez de bancos considerados grandes demais para falir, o governo pode decretar a suspensão da conversibilidade ou limites de saque para todo o sistema financeiro. Nas situações em que exista a percepção de que uma ação do governo possa vir a comprometer a capacidade de pagamento dos bancos, indicadores financeiros, tais como a solvência da instituição, deixam de ser importantes.

Berger et. al. (1998, p. 10) verificaram que as pesquisas existentes sobre se as informações obtidas pelo supervisor bancário são mais tempestivas que aquelas obtidas pelo mercado não são conclusivas. Para avaliar essa mesma situação, os autores utilizaram quatro variáveis indicativas de diferentes avaliações da situação das instituições bancárias: variação do rating BOPEC utilizado pelo FED para classificar as instituições; variação no rating de debêntures subordinadas seniores dos bancos, atribuído pela agência de risco Moody's; variação nos percentuais de ações do banco detidos por investidores institucionais e insiders (administradores e diretores) e, finalmente, os retornos anormais das ações. A conclusão é que, quando se compara a avaliação da supervisão e da agência de risco, há boa correlação, 
tanto em relação à acurácia quanto à tempestividade das classificações. A correlação é fraca quando se considera a avaliação do mercado. Essa divergência pode decorrer de uma distinção de enfoque já que, tanto supervisores quanto classificadores de risco, enfatizam o risco de insolvência enquanto os agentes de mercado priorizam a avaliação de perspectivas de geração de riqueza, no pressuposto de continuidade, isto é solvência. Essa diferença de ênfase pode explicar também um maior poder preditivo, seja das agências de risco em relação à ocorrência de problemas com as dívidas dos bancos, seja do mercado em relação à expectativa da performance futura. Em contraste, verifica-se que as informações da supervisão, quando adicionadas às de mercado, pouco contribuem para a avaliação do desempenho futuro dos bancos. As variáveis que procuraram representar a performance futura dos bancos foram: variação da inadimplência, variação da relação capital/ativos e rentabilidade sobre ativos (ROA). Essa constatação pode decorrer de uma maior ênfase da supervisão na avaliação das condições correntes e de exercer pressão sobre os bancos para solucionar problemas presentes, mas também, pode ser devida ao próprio processo de "envelhecimento" do rating que tem periodicidade anual.

A análise do fenômeno recente das crises da Argentina e Uruguai, além de confirmar a comunicação entre os diferentes tipos de crise, serve como alerta para a necessidade de ampliar-se o espectro das análises que suportam o exercício da disciplina de mercado. Isso implica em buscar a introdução de mais indicadores para análise (que meçam a exposição dos bancos aos fatores sistêmicos) e incorporar à análise a possibilidade do surgimento do problema de agência dual, com a inserção do governo como pólo agente. Esse problema é agravado nos países emergentes, nos quais diversos fatores sistêmicos, tais como taxa de câmbio, risco país e dívida pública, alteram as relações entre a resposta de mercado e os fundamentos dos bancos. 


\section{INTERVENÇÃO NO BANCO SANTOS E EFEITO CONTÁGIO}

\subsection{Metodologia da Análise}

A utilização de diferentes critérios para a identificação das crises pode levar a conclusões contrastantes em estudos de crises correlacionados, isso pode resultar na recomendação de políticas inadequadas (ISHIHARA, 2005, p. 8). No caso específico da crise bancária, Ishihara aponta quatro definições operacionais (indicadores) utilizados na análise:

- Ativos: avalia a qualidade dos ativos. A inadimplência é o indicador normalmente usado;

- Obrigações: direciona a análise para o passivo do banco e trata, em essência, das corridas bancárias;

- Capital: segundo Caprio (1996, p. 2 apud ISHIHARA, 2005, p. 3) a crise bancária ocorre quando todo ou a maior parte do capital de um banco é exaurido;

- Políticas relativas à assistência governamental: nacionalização de bancos em larga escala, congelamento de depósitos, fechamento de bancos, re-capitalização de bancos em andamento.

Ishihara (2005, p. 8) considera que para a análise de crises de liquidez o melhor indicador seria os depósitos, principalmente os depósitos à vista, porque os depósitos a prazo possuem prazo determinado e são de difícil resgate antes da maturidade. Para a crise de insolvência o indicador ideal seria o capital. Os indicadores sugeridos, na verdade, seriam a relação Depósitos à vista e Capital sobre os ativos totais. Esses indicadores são então padronizados, calculando-se o Z -Score, e comparados com padrões que definem a fronteira da normalidade, ou ausência de crise, e o autor considerou como limite adequado para a fronteira de normalidade o valor $Z \leq 2$ o qual, considerando uma distribuição normal, corresponderia a uma probabilidade de $2,5 \%$ de superação.

Schmukler et. al. (2005, p. 2) avaliam que, no contexto da disciplina de mercado, a análise dos principais indicadores financeiros dos bancos busca dimensionar a capacidade que os bancos possuem de honrar suas dívidas. Os fundamentos normalmente utilizados para 
essa análise são o nível de créditos não performados (inadimplência), o retorno sobre os ativos e o nível de capitalização.

Segundo Aharony e Swary (1983, p. 307), para se determinar se a insolvência de uma instituição financeira contagiou outros bancos, deve-se analisar as datas em que eventos críticos precedentes à falência se tornaram públicos. Num mercado eficiente, essa sinalização de deterioração da situação financeira da instituição e da sua solvência, deveria provocar uma queda imediata no preço de suas ações. Caso a informação tivesse um potencial de contágio, seu efeito deveria ser imediatamente refletido em outros bancos. A partir desse princípio básico, esses autores procuraram correlacionar os eventos dos bancos analisados (que foram à falência) com uma performance anormal de suas ações no mercado e se esse resultado também ocorreu em outros bancos, agrupados de acordo com o volume de depósitos.

Slovin et. al. (1999, p. 223) avaliaram o impacto do anúncio da redução no valor de dividendos dos bancos e dos comunicados do início de trabalhos de supervisão, por banco, sobre o preço das ações dos bancos e o efeito contágio desses anúncios no mercado e nos segmentos complexos (bancos grandes) e regionais. As principais conclusões do estudo foram:

- Os bancos que anunciaram a redução de dividendos tiveram desvalorização no valor de suas ações;

- A redução no valor das ações é diretamente relacionada ao valor da redução e ao desempenho pretérito da ação;

- Uma redução maior de valor é observada nos bancos que após a divulgação da redução no valor dos dividendos, sofreram ações de fiscalização;

- Há uma redução maior no valor das ações, quando os motivos da redução de dividendos são específicos do banco anunciante;

- As reduções de dividendos ocorridas nos bancos grandes afetam negativamente os preços das ações de todos os demais. Esse fenômeno de contágio não se observa nas reduções anunciadas pelos bancos regionais em relação ao mercado como um todo;

- Contudo as reduções de dividendos em bancos regionais, devidas a problemas específicos dos bancos anunciantes, acarretam um aumento no preço das ações dos concorrentes da mesma região geográfica, em virtude dos efeitos sobre a competição bancária; 
- O anúncio de ações de fiscalização de caráter específico para o banco analisado gera redução no preço das ações desse banco e aumento no preço das ações da concorrência;

- Esse aumento do valor das ações dos bancos concorrentes, seja pela redução no pagamento dos dividendos, seja pela ocorrência de ações de natureza fiscalizadora, denotam a ocorrência de competição imperfeita nos mercados regionais o que é consistente com a visão de Peltzman (1965 apud. SLOVIN et. al., 1999, p. 225), de que a regulação reduz a competição na indústria bancária.

Cooperman et. al. (1996, p. 936) verificaram um aumento do prêmio de risco pago nos depósitos de seis meses de bancos e instituições de poupança em 1985, época da crise das companhias de poupança e empréstimo da região de Ohio, Estados Unidos. Esse aumento de prêmio foi maior nas empresas menos solventes e durou cerca de sete semanas. O prêmio adicional decorreu da percepção do mercado de que o fundo garantidor de depósitos estava insolvente. A constatação confirma não só a ocorrência do contágio, mas também realça a influência que o seguro-depósito tem na estabilidade do sistema.

No mercado brasileiro, o reduzido número de instituições bancárias com ações listadas em bolsa não permite a análise do impacto de eventos importantes no preço das ações, que seria o indicativo da ocorrência de contágio ou de propagação para o restante do mercado.

Alternativamente, optou-se pela utilização das informações contábeis das instituições financeiras disponibilizadas no site do Banco Central do Brasil: www.bcb.gov.br/?IF. Essa opção, embora seja a única disponível para o tipo de análise pretendida, padece de pelo menos dois aspectos indesejáveis: por se tratarem de dados mensais, há uma perda de precisão em relação à análise que utiliza dados diários dos preços das ações; e tratam-se de dados elaborados e fornecidos pelas instituições, que não se encontram portanto, submetidos ao processo de escrutínio e validação do mercado.

Contrapõem a esses aspectos negativos a possibilidade de analisar-se de forma direta o comportamento das rubricas contábeis referentes aos depósitos bancários, que é a variável relevante no estudo de crise de liquidez. Além disso, outro fator que pode ser considerado positivo é a extrema padronização do Plano Contábil das Instituições Financeiras (COSIF) que facilita sobremaneira a comparação e análise estatística entre instituições.

$\mathrm{Na}$ definição do tamanho e período da base de dados, foram adotadas as seguintes premissas: 
- Adotou-se um intervalo de três anos, de janeiro de 2003 a dezembro de 2005, para a análise. A intenção, ao escolher esse período, foi de obter um período razoável de observações antes e após a data da liquidação do Banco Santos (nov. 2004).

- Na escolha do intervalo, considerou-se também que a utilização de períodos mais antigos, antes de janeiro de 2003, além de pouco acrescer à análise, poderia estar contaminada pelo processo de consolidação verificado no passado recente. Além disso, o próprio desenvolvimento da indústria e dos produtos bancários conduz a alteração do perfil e do volume dos negócios, com efeitos diretos na alocação de recursos e na composição das rubricas contábeis;

- Foram escolhidas para integrar o universo de análise apenas instituições que tivessem saldo contábil na rubrica de depósitos e cujos saldos fossem, em média, de R $\$ 50$ milhões ao longo de todo o período. De acordo com esse critério, foram selecionadas 84 instituições que, em relação ao sistema bancário de junho de 2004, representavam, 97,3\% dos Ativos Totais, 92,9\% do Patrimônio Líquido e 99,6\% dos Depósitos. A tabela 1, contendo informações extraídas do site do Banco Central do Brasil: www.bcb.gov.br/?INFCADASTRO detalha esses percentuais. Na obtenção do total do sistema bancário foram excluídos os valores relativos ao Banco Nacional de Desenvolvimento Econômico e Social (BNDES) que não capta depósitos do público e portanto, não apresenta interesse para a presente análise. As tabelas 2 e 3 relacionam as 84 instituições selecionadas. 
Tabela 1 - Comparativo amostra X Sistema Bancário Nacional

Dados consolidados do Sistema Financeiro referente a jun.04, mês intermediário do período analisado e próximo ao mês do evento em estudo. O BNDES foi excluido por não captar depósitos. Fonte: site bcb.gov.br/?INFCADASTRO. Acesso abr.06. Em R\$ mil.

Conglomerado Bancário I: Conglomerado em cuja composição se verifica pelo menos uma instituição do tipo Banco Comercial ou Banco Múltiplo com Carteira Comercial.

Conglomerado Bancário II: Conglomerado em cuja composição não se verificam instituições do tipo Banco Comercial e Banco Múltiplo com Carteira Comercial, mas que conta com pelo menos uma instituição do tipo Banco Múltiplo sem Carteira Comercial, Banco de Investimento e Banco de Desenvolvimento

\begin{tabular}{lrrr}
\hline & Ativo Total & $\begin{array}{c}\text { Depósito } \\
\text { Total }\end{array}$ & $\begin{array}{c}\text { Patrimônio } \\
\text { Líquido }\end{array}$ \\
\hline Conglomerado Bancario I ( 108 Instituicoes ) & 1.220 .101 & 499.376 & 109.750 \\
Conglomerado Bancario II ( 28 Instituicoes ) & 21.986 & 6.307 & 4.159 \\
Sistema Bancário Nacional - 136 instituições & 1.242 .087 & 505.683 & 113.909 \\
Universo Amostral - 84 instituições & 1.208 .020 & 503.583 & 105.832 \\
Participação do Universo Amostral & $97,3 \%$ & $99,6 \%$ & $92,9 \%$ \\
\hline
\end{tabular}


Tabela 2 - Bancos que compõem a amostra

\begin{tabular}{|c|c|c|c|}
\hline \multirow{2}{*}{\multicolumn{4}{|c|}{$\begin{array}{l}\text { Relação de bancos utilizados na análise, ordenados pelo ativo to } \\
\text { representar um mês intermediário ao período analisado (jan.03 } \\
\text { intervenção. Valores em R } \$ \text { mil. } \\
\text { Fonte:sitehttp://www5.bcb.gov.br/fis/cosif/principal.asp?id=if. }\end{array}$}} \\
\hline & & & \\
\hline & Ativo Total & Depósitos & Patrimônio Líquido \\
\hline $\mathrm{BB}$ & 227.374 .440 & 115.795 .343 & 12.863 .546 \\
\hline $\mathrm{CEF}$ & 166.697 .413 & 83.838 .057 & 5.792 .888 \\
\hline Bradesco & 145.314 .420 & 64.309 .978 & 13.668 .044 \\
\hline ITAU & 113.030 .224 & 36.632 .536 & 13.746 .705 \\
\hline Unibanco & 72.189 .934 & 29.615 .481 & 7.937 .366 \\
\hline SantanderBanespa & 66.105 .737 & 19.108 .424 & 8.088 .284 \\
\hline $\mathrm{ABN}$ & 58.462 .933 & 26.919 .230 & 8.792 .934 \\
\hline Safra & 38.655 .179 & 8.791 .407 & 3.432 .601 \\
\hline Votorantim & 34.907 .003 & 11.618 .546 & 3.013 .760 \\
\hline HSBC & 32.340 .080 & 19.428 .156 & 2.099 .976 \\
\hline Citibank & 29.827 .939 & 3.148 .051 & 3.162 .752 \\
\hline NossaCaixa & 27.546 .414 & 19.831 .063 & 1.822 .157 \\
\hline BankBoston & 20.274 .290 & 3.219 .618 & 2.954 .331 \\
\hline BNB & 13.249 .516 & 2.652 .557 & 1.241 .351 \\
\hline Pactual & 12.465 .119 & 1.197 .045 & 551.860 \\
\hline Banrisul & 12.307 .113 & 7.112 .186 & 835.381 \\
\hline CreditSuisse & 10.495 .704 & 3.231 .943 & 728.993 \\
\hline JPMorgan & 8.402 .720 & 2.067 .051 & 1.260 .546 \\
\hline Alfa & 7.546 .245 & 2.278 .116 & 1.105 .132 \\
\hline Rural & 7.245 .079 & 4.396 .045 & 715.121 \\
\hline Fibra & 6.865 .137 & 1.104 .047 & 428.260 \\
\hline Santos & 6.293 .414 & 2.105 .283 & 600.719 \\
\hline $\mathrm{BIC}$ & 5.577 .870 & 2.117 .087 & 403.534 \\
\hline Deutsche & 5.516 .217 & 755.843 & 174.180 \\
\hline MercantildoBrasil & 4.236 .477 & 2.715 .415 & 420.180 \\
\hline BASA & 4.203 .516 & 1.109 .436 & 1.408 .965 \\
\hline Volkswagen & 4.141 .277 & 2.088 .243 & 573.006 \\
\hline BBM & 4.054 .013 & 1.368 .632 & 344.690 \\
\hline BESC & 3.596 .634 & 2.116 .611 & 186.294 \\
\hline CruzeirodoSul & 3.489 .703 & 432.493 & 127.819 \\
\hline Rabobank & 3.387 .632 & 303.302 & 156.949 \\
\hline SS & 2.845 .856 & 1.971 .961 & 305.224 \\
\hline Banestes & 2.842 .445 & 1.897 .443 & 157.710 \\
\hline AbcBrasil & 2.772 .327 & 1.016 .918 & 368.422 \\
\hline GMAC & 2.544 .204 & 1.671 .168 & 325.582 \\
\hline $\mathrm{BMG}$ & 2.435 .266 & 1.493 .893 & 392.189 \\
\hline CooperativoSicredi & 2.234 .607 & 448.464 & 81.759 \\
\hline $\mathrm{BMC}$ & 2.145 .868 & 1.022 .940 & 229.916 \\
\hline $\mathrm{BRB}$ & 2.071 .178 & 1.392 .904 & 245.989 \\
\hline CooperativoBrasil & 1.912 .686 & 495.350 & 53.976 \\
\hline Dresdner & 1.847 .182 & 3.921 & 288.778 \\
\hline Ibi & 1.719 .534 & 615.376 & 304.682 \\
\hline TokioMitsubishi & 1.699 .287 & 145.725 & 335.602 \\
\hline
\end{tabular}


Tabela 3 - Bancos que compõem a amostra. cont. Tab. 2

\begin{tabular}{|c|c|c|c|}
\hline \multicolumn{4}{|c|}{$\begin{array}{l}\text { Relação de bancos utilizados na análise, ordenados pelo ativo tot } \\
\text { representar um mês intermediário ao período analisado (jan.03 a } \\
\text { intervenção. Valores em } \mathrm{R} \$ \text { mil. } \\
\text { Fonte:sitehttp://www5.bcb.gov.br/fis/cosif/principal.asp?id=if. }\end{array}$} \\
\hline & Ativo Total & Depósitos & Patrimônio Líquido \\
\hline DaimlerChrysler & 1.616 .342 & 147.888 & 172.052 \\
\hline Pine & 1.499 .473 & 594.544 & 162.447 \\
\hline $\mathrm{BEC}$ & 1.465 .588 & 712.943 & 308.842 \\
\hline Sofisa & 1.353 .682 & 777.631 & 241.748 \\
\hline Daycoval & 1.251 .734 & 646.826 & 277.423 \\
\hline Cacique & 1.176 .471 & 526.012 & 247.091 \\
\hline $\mathrm{ING}$ & 1.158 .886 & 186.214 & 280.444 \\
\hline IndustrialdoBrasil & 1.124 .891 & 374.001 & 125.008 \\
\hline Modal & 1.088 .874 & 131.900 & 69.045 \\
\hline Schahin & 926.462 & 622.918 & 107.639 \\
\hline BES & 840.197 & 391.222 & 79.659 \\
\hline SocieteGeneral & 766.825 & 154.902 & 117.755 \\
\hline Brascan & 759.851 & 233.041 & 267.101 \\
\hline Prosper & 742.546 & 76.937 & 57.645 \\
\hline Indusval & 737.960 & 248.192 & 64.705 \\
\hline Ford & 698.100 & 272.436 & 194.330 \\
\hline Banif & 686.746 & 95.217 & 33.968 \\
\hline Triangulo & 676.037 & 465.260 & 116.292 \\
\hline Tricury & 676.037 & 465.260 & 116.292 \\
\hline Rendimento & 536.877 & 112.386 & 54.156 \\
\hline Socopa & 514.172 & 97.104 & 35.790 \\
\hline Arbi & 441.589 & 23.519 & 25.277 \\
\hline PSAFinance & 441.422 & 307.447 & 67.115 \\
\hline Toyota & 415.323 & 187.077 & 81.272 \\
\hline BGN & 373.766 & 221.478 & 30.581 \\
\hline AMEX & 366.960 & 107.931 & 134.547 \\
\hline JMalucelli & 280.499 & 199.418 & 55.152 \\
\hline Intercap & 272.288 & 216.922 & 40.584 \\
\hline Credibel & 258.068 & 183.725 & 65.640 \\
\hline Pecunia & 252.160 & 164.640 & 42.085 \\
\hline Honda & 242.228 & 118.076 & 50.731 \\
\hline Bonsucesso & 212.785 & 162.006 & 26.304 \\
\hline Ficsa & 206.719 & 120.695 & 69.744 \\
\hline LusoBrasileiro & 204.301 & 141.079 & 36.209 \\
\hline Guanabara & 186.155 & 90.903 & 59.415 \\
\hline AJRenner & 149.420 & 88.344 & 50.956 \\
\hline Gerdau & 145.373 & 108.189 & 28.525 \\
\hline Morada & 143.841 & 63.039 & 32.627 \\
\hline Matone & 126.697 & 87.735 & 32.470 \\
\hline Cedula & 91.319 & 53.521 & 31.187 \\
\hline Emblema & 41.105 & 20.709 & 13.643 \\
\hline Total da Amostra & 1.208 .019 .601 & 503.582 .576 & 105.831 .652 \\
\hline
\end{tabular}




\subsection{Histórico dos Eventos}

A virulência do contágio está relacionada de forma direta com o fato originador. Conforme Aharony e Swary (1983, p. 306), para se identificar o contágio puro deve-se considerar em que medida a informação proporcionada pela falência de determinada instituição se relaciona com outras. Essa informação só pode obtida a partir do contexto histórico em que o fato transcorreu. O histórico dos eventos permite também avaliar em que medida o mercado conseguiu antecipar a situação de deterioração do banco, e qual a participação dos diversos agentes envolvidos com o evento, seja no período pré-crise ou pós-crise.

O histórico, incluído no Apêndice IV, foi construído a partir das manchetes ou temas principais de diversas matérias divulgadas pela mídia. Essa abordagem é interessante, pois permite, a partir de uma perspectiva de fato já ocorrido, avaliar o movimento dos diversos interesses, seja com o intuito de prover informação imparcial, seja como instrumento de propaganda institucional, nesse caso para a construção de uma imagem de solidez que garantisse à instituição sua sobrevivência.

\subsection{Percepção do Mercado sobre a Situação do Banco Santos}

\subsubsection{Análise Gráfica}

Como o banco não tem ações cotadas em bolsa, a avaliação da percepção do mercado sobre a situação do Banco Santos no período anterior à intervenção será feita de forma indireta, utilizando os dados contábeis da conta depósitos e outras que forem julgadas, subsidiariamente, úteis.

Para essa análise, confeccionou-se a matriz de correlação dos dados da conta Depósitos dos 84 bancos selecionados, considerando-se o período de jan.2003 a set.2004, que se entendeu como ainda não contaminada pelos efeitos da intervenção no Banco Santos. Foi criada uma outra variável, denominada total da amostra, que consolida os saldos de todas as instituições utilizadas na amostra, representado o comportamento global da amostra e até, pelo volume de depósitos que abrange, pode ser considerada como boa representante dos valores relativos a todo o sistema financeiro nacional. $O$ gráfico 1 apresenta $o$ 
comportamento dos depósitos totais do Banco Santos em relação instituições de maior porte, portanto menos afetadas, e, também, com o total da amostra. Como a análise gráfica pretende averiguar apenas a tendência de crescimento e, como o volume dos depósitos é bastante variável a depender do porte da instituição, foi feita uma padronização para as instituições utilizadas, adotando-se o valor 1 para o primeiro período (janeiro de 2003).

\section{Gráfico 1 - Fator de crescimento dos depósitos}

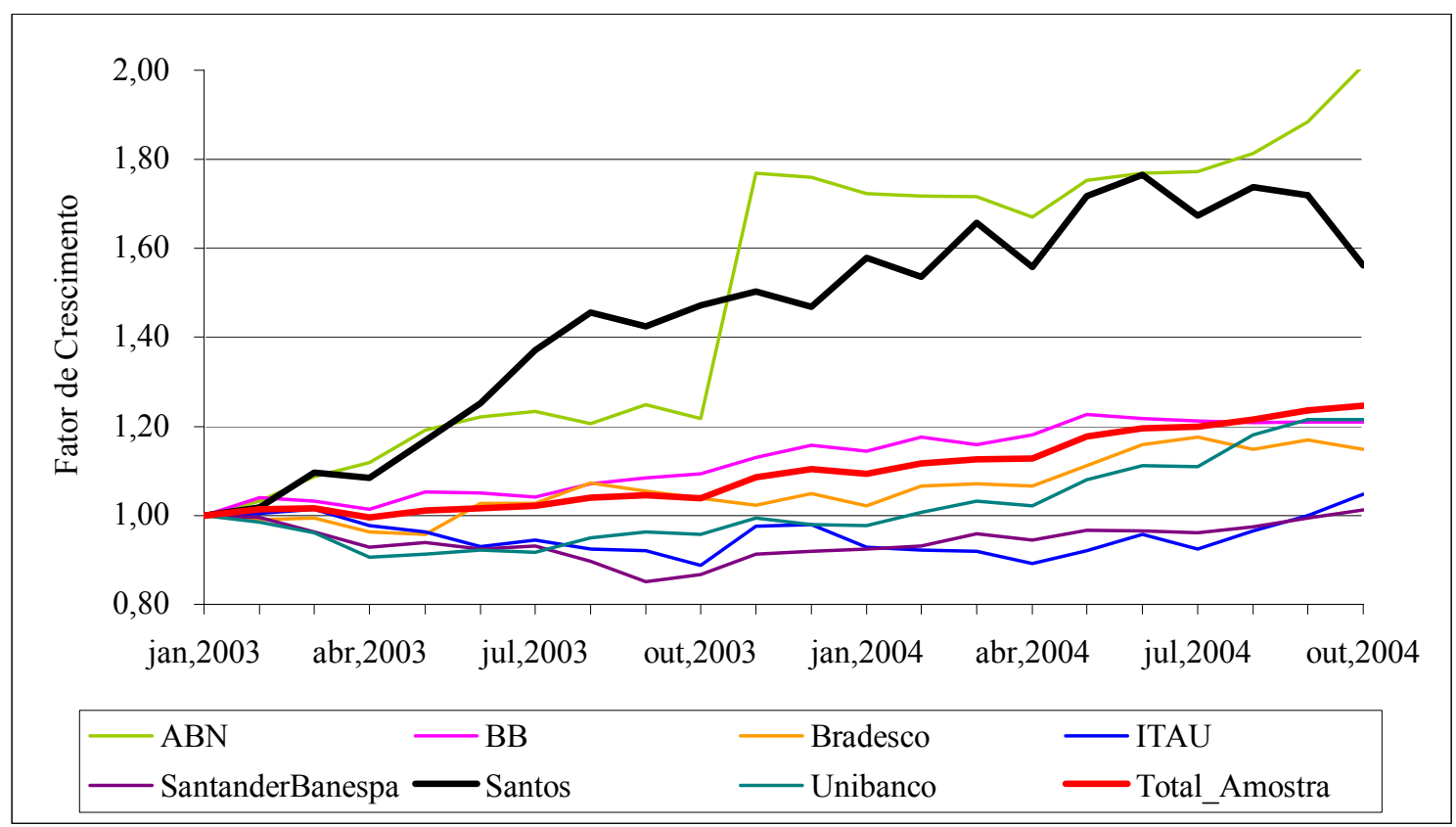

A evolução dos depósitos do Banco Santos apresenta, a partir de 2004, um comportamento de relativa volatilidade (dente de serra), porém com crescimento consistente, superior ao do grupo de controle (BB, ABN, Santander Banespa, Unibanco, Bradesco, Itaú e total da amostra), até junho de 2004. A partir desse mês observa-se uma tendência de queda, embora em agosto e setembro verifique-se uma relativa estabilidade e, somente em outubro de 2004, constata-se uma queda acentuada, indicativo de um princípio de corrida bancária que, provavelmente, foi o fator determinante para a intervenção.

Como o gráfico do Banco Santos apresenta, desde janeiro de 2003 (mês adotado como referência), um crescimento mais acentuado, é importante apresentar uma outra visualização que possibilite avaliar a evolução mensal desses depósitos. O gráfico 2 com o fator de crescimento mensal da conta Depósitos [(saldo do mês atual/saldo do mês anterior)1], procura demonstrar essa evolução. 
Gráfico 2 - Variação relativa da conta depósitos

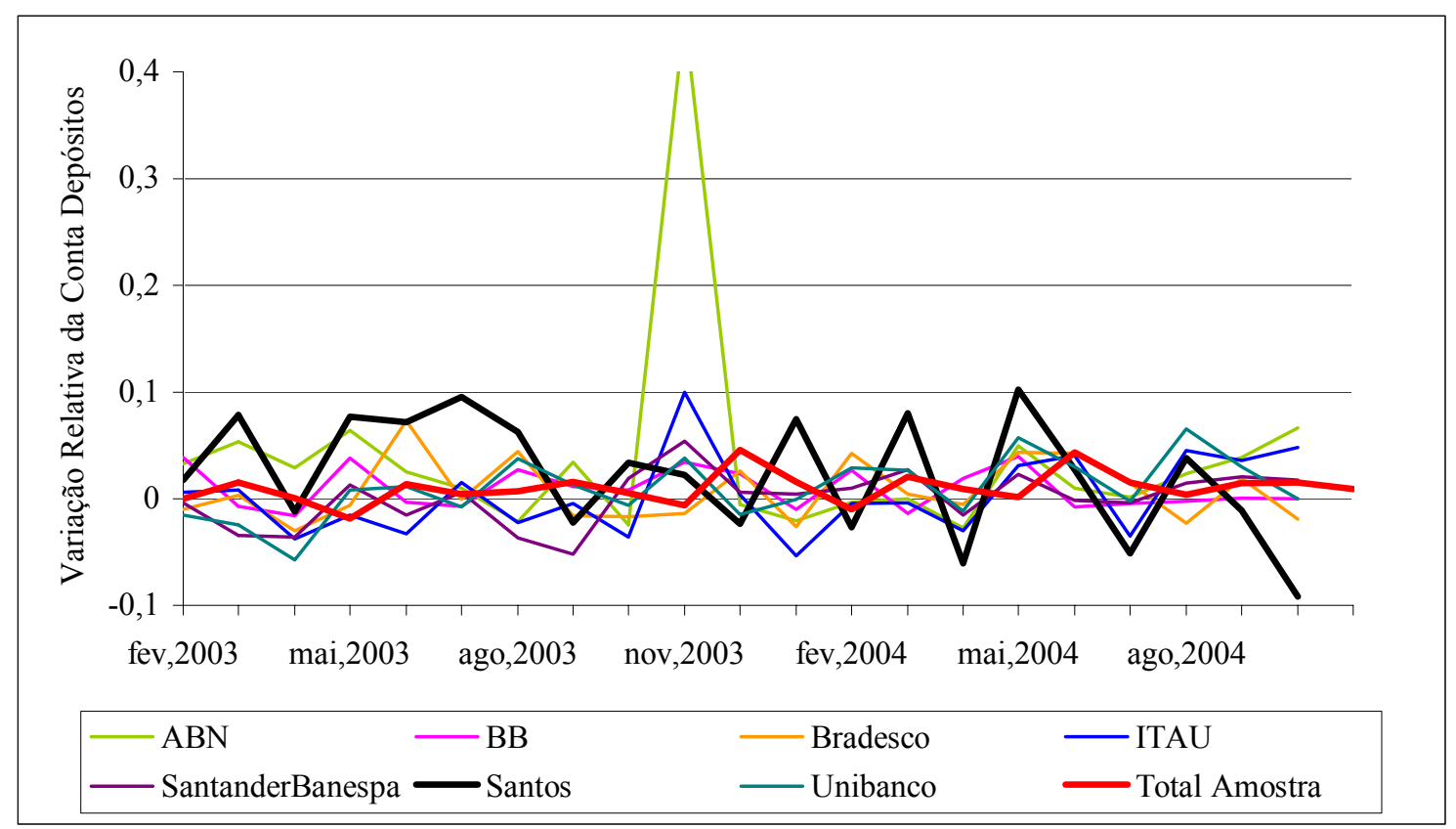

Observa-se que os saldos de depósitos do Banco Santos apesar de apresentarem um comportamento mais volátil, não demonstram uma tendência definitiva de queda até próximo à intervenção. O próprio movimento da variação dos saldos, embora com maior amplitude, acompanha o movimento do mercado nos meses de maio a agosto, tornando mais difícil a confirmação de um comportamento consistente de queda.

\subsubsection{Análise de Correlações entre as Instituições}

Foi feita também a verificação da existência de correlação entre os saldos dos depósitos do Banco Santos, grandes instituições e o total da amostra. Utilizou-se o programa de análise estatística SPSS e foi utilizado o mesmo período de 21 meses (janeiro de 2003 a setembro de 2004). Os valores obtidos constam da tabela 4: 
Tabela 4 - Resumo de correlações

\begin{tabular}{|c|c|c|}
\hline \multicolumn{3}{|c|}{$\begin{array}{l}\text { Análise entre as correlações dos saldos das contas Depósitos do Banco Santos e de } \\
\text { alguns bancos grandes e os saldos totais da amostra utilizada. Período jan.03 a set.04. } \\
\text { Fonte:http:www.bcb.gov.br/?INFCADASTRO }\end{array}$} \\
\hline & Correlação & Significância \\
\hline$\overline{\mathrm{ABN}}$ & 0,903 & 0,000 \\
\hline $\mathrm{BB}$ & 0,958 & 0,000 \\
\hline Bradesco & 0,918 & 0,000 \\
\hline $\mathrm{CEF}$ & 0,978 & 0,000 \\
\hline HSBC & 0,980 & 0,000 \\
\hline Itaú & $-0,141$ & 0,542 \\
\hline Nossa Caixa & 0,967 & 0,000 \\
\hline Safra & 0,605 & 0,004 \\
\hline Santander Banespa & 0,352 & 0,117 \\
\hline Unibanco & 0,924 & 0,000 \\
\hline Santos & 0,889 & 0,000 \\
\hline
\end{tabular}

Verifica-se, de imediato, uma correlação altamente positiva $(0,889)$ e significativa entre o comportamento dos depósitos do Banco Santos e o total da amostra. Esse resultado se repete com intensidade em relação aos demais bancos, excetuando-se os bancos Itaú e o Santander Banespa, que não apresentam correlação significativa com o total da amostra Essa elevada correlação associada à análise gráfica demonstra que o banco não sofreu, até o mês anterior à liquidação, resgates de depósitos em volumes significativos indicando que, de fato, o mercado não antecipou ou anteviu qualquer sinalização sobre a deterioração da situação do banco.

É claro que essa afirmação se baseia em dados contábeis, o que torna a avaliação da profundidade dessa deficiência de informação mais difícil. O mercado para o monitoramento e avaliação das empresas utiliza, além das demonstrações financeiras, um extenso rol de sinalizadores externos. O resultado final desse processo de avaliação é consignado no preço de mercado das ações. Como o Banco Santos não tinha ações negociadas em bolsa, as demonstrações financeiras restam como principal sinalizador a ser considerado.

Devemos considerar, porém, que a presença de diversos agentes qualificados, tais como: fundos de investimentos, bancos estrangeiros e fundos pensão, no rol de credores habilitados à falência indicam que o grau de antecipação da deterioração financeira da instituição foi reduzido. Esses entes financeiros são participantes ativos do mercado, contam com suporte de provedores de informação de elevada qualidade (agências de classificação de risco, consultorias, etc.) e se relacionam de forma freqüente com os mais diversos intermediários financeiros. Tratam-se, portanto, de agentes bem informados que teriam uma vantagem comparativa em antever as dificuldades da instituição. 
Uma justificativa, apontada por Beck (2003, p. 4), é a de que os grandes depositantes, como possuem maior capacidade de monitorar os bancos, percebem que a cobertura do seguro-depósito, destinado a garantir os depósitos de pequenos investidores, pode vir a ser estendida a eles em momentos de crise, e eles podem relaxar esse processo de monitoramento.

Não parece ser o caso brasileiro, pois as liquidações recentes de bancos de pequeno e médio porte demonstraram que essa extensão de cobertura não se verificou. Não havia portanto informação, ela era incompleta ou então ela foi contrabalançada com informações de sinal contrário, gerando ruído e indecisão nos agentes.

O grau da deficiência na informação, ou pelo menos a capacidade da instituição mantê-la sigilosa, está plenamente evidenciado nos quatro trechos a seguir apresentados, extraídos do edital de convocação de credores (OLIVEIRA, 2005):

[...] em sentença datada de 20 de setembro de 2005 , foi decretada a falência do BANCO SANTOS S/A [...] cuja íntegra é do seguinte teor: 'Vistos. BANCO SANTOS S/A, em liquidação extrajudicial, sociedade anônima fechada, estabelecida nesta Capital, através do seu liquidante nomeado, requer a decretação de autofalência, aduzindo que, durante o procedimento previsto em lei, após reclassificações e balanceamento de seus ativos e passivos, apurou-se um passivo a descoberto da ordem de $\mathrm{R} \$ 2.236 .078 .000,00$, afora outros prejuízos que ainda podem elevá-lo, de tal sorte que este fato, por si só, revelaria a sua situação de total insolvência.

Ainda segundo a inicial, não bastasse essa situação, verificou-se em relação à sua administração durante a tramitação de inquérito instaurado pelo Banco Central do Brasil, diversas práticas irregulares pelos ex-administradores e controladores, algumas delas com participação dos próprios devedores, que acabaram por impedir exames e avaliação de investidores e analistas do mercado sobre a sua real situação financeira. Mais ainda, eram comuns operações que tinham por objetivo transferir ou desviar recurso para empresas não financeiras ou cobrir ativos insubsistentes de exercícios anteriores.

Inegavelmente, à vista da documentação que acompanha o requerimento de autofalência e, também, das conclusões da Comissão de Inquérito do Banco Central, o ativo do reqte. é infinitamente inferior aos seus débitos, não havendo qualquer possibilidade de cobertura de metade dos créditos quirografários. Em ação civil pública proposta pelo Ministério Público, contra os administradores da sociedade em liquidação, apurou-se passivo a descoberto, com base nas conclusões do inquérito do BACEN, da ordem de R $\$ 2.235 .802 .000,00$, afora prejuízos não quantificados, notadamente a fundos de investimentos e ao BNDES, demonstrando gestão nefasta na administração do Banco e, mais ainda, a prática de atos ilícitos, muitos deles a caracterizar crime. Entre outros, constatou-se, durante a tramitação de inquérito, operações irregulares com debêntures, caracterizando emissão pública, sem registro prévio na Comissão de Valores Mobiliários; aquisição de cédulas de produtos rural já quitadas, com transferência de valores do Banco para pessoas jurídicas ligadas a seu controlador; operações irregulares com contratos de cessão de créditos de exportação (export notes); aplicação de recursos públicos (BNDES) com finalidade diversa da prevista em lei ou contrato, além de empréstimos a empresas ligadas e aplicações em opções flexíveis ativas (empréstimos dissimulados).

Basicamente, os ativos do Banco são constituídos por créditos, muitos de duvidosíssima liquidação, havendo dezenas de ações judiciais em que os seus devedores invocam provimento jurisdicional para a proclamação de extinção de suas obrigações pela ocorrência de compensação ou por operações simuladas. [...] o fato é que a gravidade das ocorrências constatadas no caso específico, aconselham a decretação desde logo da falência, para permitir o quanto antes, a 
apuração de delitos e a recuperação, ainda que pequena, dos direitos da imensa massa de credores prejudicados. Em face do exposto, decreto a falência da reqda., [... ]

Indubitavelmente, o maior destaque do trecho apresentado, é o volume do passivo a descoberto, da ordem de $\mathrm{R} \$ 2.236$ milhões. O próprio fundamento para a decretação da falência, “... inexistência de ativos suficientes para sequer cobrir metade dos créditos quirografários...", dá a dimensão exata do estado de insolvência da instituição. Outro apontamento digno de nota nos termos do próprio edital é " [...] demonstrando gestão nefasta na administração do Banco e, mais ainda, a prática de atos ilícitos, muitos deles a caracterizar crime".

A relação de credores habilitados, constante do edital de convocação de credores, permite avaliar a composição dos principais grupos de clientes afetados pela liquidação do banco. Adotou-se para a montagem da tabela 5, um agrupamento de clientes em categorias compatíveis com os nomes constantes do edital.

\section{Tabela 5 - Perfil dos credores do Banco Santos}

\begin{tabular}{|c|c|c|c|c|}
\hline \multicolumn{5}{|c|}{$\begin{array}{l}\text { Composição, por tipo de cliente, do universo de credores habilitados à falência do Banco } \\
\text { Santos. Foram excluidos da análise os créditos de natureza fiscal. Fonte: Edital de convocação } \\
\text { de credores. Em } \mathrm{R} \$ \text { mil. }\end{array}$} \\
\hline Tipo de depositante & Valor & $\begin{array}{l}\text { Número de } \\
\text { depósitantes }\end{array}$ & Valor médio & Participação \\
\hline empresa & 541.611 & 943 & 574 & $20,4 \%$ \\
\hline fundo de investimento & 499.715 & 94 & 5.316 & $18,8 \%$ \\
\hline banco estrangeiro & 494.131 & 39 & 12.670 & $18,6 \%$ \\
\hline fundo de pensão & 346.399 & 23 & 15.061 & $13,1 \%$ \\
\hline investidor estrangeiro & 232.133 & 7 & 33.162 & $8,8 \%$ \\
\hline pessoa fisica & 149.503 & 784 & 191 & $5,6 \%$ \\
\hline banco nacional & 93.491 & 5 & 18.698 & $3,5 \%$ \\
\hline fundo de governo & 73.363 & 1 & 73.363 & $2,8 \%$ \\
\hline associação & 68.000 & 27 & 2.519 & $2,6 \%$ \\
\hline banco desenvolvimento & 55.609 & 6 & 9.268 & $2,1 \%$ \\
\hline corretora & 37.442 & 5 & 7.488 & $1,4 \%$ \\
\hline fundação & 30.922 & 12 & 2.577 & $1,2 \%$ \\
\hline cooperativa & 21.072 & 26 & 810 & $0,8 \%$ \\
\hline prefeitura & 3.478 & 1 & 3.478 & $0,1 \%$ \\
\hline cfi & 2.381 & 2 & 1.190 & $0,1 \%$ \\
\hline seguradora & 1.709 & 3 & 570 & $0,1 \%$ \\
\hline depósitos judiciais & 116 & 23 & 5 & $0,0 \%$ \\
\hline Total & 2.651 .075 & 2.001 & & $100,0 \%$ \\
\hline
\end{tabular}

Verifica-se que os grupos: fundos de investimentos, fundos de pensão e bancos estrangeiros, correspondem a 156 clientes, somando $\mathrm{R} \$ 1.340$ milhões de créditos ou 50,6\% do total do passivo habilitado à falência. Esse elevado percentual de participação de clientes 
qualificados, potencialmente melhor informados, indica que esse grupo não antecipou a deterioração da situação do banco. É especialmente relevante a presença, entre os credores, de bancos estrangeiros, 39, com um valor total de R $\$ 494$ milhões. Entre os bancos nacionais, essa presença é bem menor, são apenas cinco, sendo que dois bancos públicos respondem por cerca de $\mathrm{R} \$ 82$ milhões do total de $\mathrm{R} \$ 93,5$ milhões atribuído a esse grupo. Certamente, os bancos constituem o grupo mais bem informado, entre os agentes do mercado financeiro. Essa seria uma possível razão para a baixa participação dos bancos nacionais como credores da massa falida. Contudo, para testar esta hipótese, teria que ser feito um comparativo desses valores com um histórico de volume e número de operações do mercado bancário com o Banco Santos, dados esses que não são publicamente disponíveis.

Outro dado interessante que consta do edital é um volume de cerca de R $\$ 15$ milhões referentes a créditos do Fundo Garantidor de Créditos (FGC). Esse valor deve representar o total ressarcido aos detentores de depósitos de até R \$20 mil. Esse montante de indenização indica que o Banco Santos não contava com uma grande pulverização na captação de depósitos, o que é coerente com seu perfil de atuação e com o próprio segmento em que atuava.

Porém, o aspecto mais importante que o volume indenizado parece relevar é a sua baixa cobertura em relação ao montante total da dívida pendente. Ou seja, para esse tipo de instituição o potencial de risco moral normalmente associado ao seguro-depósito é substancialmente reduzido, pois a cobertura de risco propiciada aos depositantes é totalmente incompatível com um afrouxamento do exercício da disciplina de mercado. Os depositantes, sobretudo de grandes valores, teriam grandes motivos para exercer um monitoramento rigoroso da instituição.

\subsubsection{Benefício de Imagem}

O ruído na informação é coerente com as idéias anteriormente detalhadas no trabalho de Welch (1992) sobre a sensibilidade das cascatas de informação à divulgação de informações públicas. Nesse caso, uma hipótese plausível é que os agentes, embora tivessem algum nível de sinalização particular sobre a situação real do banco, receberam informação pública que teve o poder de demover os indivíduos de tomarem a ação correta (resgate dos recursos). 
Mas que tipo de informação pública esses indivíduos poderiam ter recebido? O histórico de eventos (Apêndice IV) dá uma boa pista. O Banco Santos enfatizava sobremaneira suas ações de propaganda e publicidade institucional. Pelo histórico de eventos, verifica-se que os representantes do banco apresentavam-se de forma freqüente na mídia para comentar os mais diversos aspectos da vida econômica do país (por exemplo, comentários sobre a divulgação da taxa Selic). A propaganda institucional destacava principalmente a inovação e a capacidade tecnológica. Essas duas ações utilizadas de forma sistemática continham elevado potencial para construir a imagem da capacidade técnica.

A solidez da instituição foi outro aspecto fortemente trabalhado. $O$ banco, que originariamente era um "banco de andar", instalado num prédio próximo à avenida Paulista, passou a ocupar um prédio de linhas neoclássicas em local de elevada visibilidade, na Avenida das Nações Unidas (Marginal Pinheiros), em frente ao Jockey Club de São Paulo. O local, a arquitetura portentosa, a instalação de réplicas de esculturas dos profetas de "Aleijadinho" e a iluminação cuidadosa, deram realce extremado ao banco que deixou, de forma definitiva, o anonimato. Dificilmente essa imagem não poderia ser associada à solidez.

O proprietário do banco poderia ser considerado o terceiro sustentáculo na construção da imagem da instituição. Sua figura ganhou destaque como "Mecenas das Artes". Participou ativamente de diversas ações culturais e artísticas, com destaque para Exposição Brasil 500 anos, e era personagem freqüente em festas e matérias de revistas de eventos sociais. Ele, de forma diversa da família Safra, que construiu uma mansão de forma bastante discreta, deu ampla divulgação à inauguração de sua nova residência que também tinha dimensões grandiosas. Impossível deixar de associar essa ostentação com riqueza abundante, mesmo porque, certamente essa é a visão que o imaginário popular atribui ao banqueiro. Essa interpretação é corroborada por trechos de em algumas notas de jornal:

- Jornal Zero Hora, 2004

À exceção de uma ou duas consultorias especializadas, o anúncio da intervenção do Banco Central (BC) no Banco Santos, na noite de sexta-feira, foi uma surpresa. Principalmente porque seu fundador e controlador, Edemar Cid Ferreira, é o tipo de homem de negócios que parece precisar apenas estalar os dedos para que o mundo se molde a seus objetivos;

- (NASSIF, 2004):

Fontes do mercado estimam que o processo de dilapidação do patrimônio do banco tenha começado há cinco anos.

No último Baile da Ilha Fiscal de Comandatuba, Edemar foi escolhido o "líder empresarial do ano; 
- (GANCIA, 2004):

Personagem maior do que a vida, no que pesa a sua imagem como mecenas e como figura exótica, o controlador do Banco Santos, Edemar Cid Ferreira, irá deixar a sua marca.

Seu casarão no Morumbi é um capítulo à parte. O projeto do interior é de Peter Marino, arquiteto que desenhou algumas das lojas mais transadas do mundo da moda, como a Barneys, de Nova York, e a Chanel Tower, de Tóquio. Marino, que teve Andy Warhol como seu primeiro grande cliente, confidenciou recentemente a uma amiga brasuca que Edemar é a pessoa "mais excêntrica" para quem já trabalhou.

- Folha de São Paulo, 2004:

Nenhum veículo noticiou com clareza que a situação do banco era difícil. A revista "Exame" do dia 13 de outubro tem uma reportagem ("Banco Santos altera sua estratégia") que dá a entender que a instituição tinha problemas, mas não é explícita. Seu enfoque é o mesmo das notas da Folha: positivo e acrítico.

É compreensível que a Folha não tenha publicado os rumores. Mas nada justifica que tenha alimentado a idéia de que a situação do banco era saudável. O interesse do banco foi preservado, mas não o do leitor.

Possivelmente, essas ações geraram um conjunto de sinais suficientemente fortes para contrapor quaisquer sinalizações antagônicas do mercado. A subseqüente reação, aparentemente exagerada (overshooting) do mercado, resgatando recursos de outras instituições do mesmo segmento, parece confirmar que o mercado foi surpreendido com a notícia da liquidação. A esse evento, em que os indivíduos vislumbram uma imagem da instituição mais positiva que a real, poderia se atribuir a denominação de prêmio, (ou) bônus de imagem.

Seria o antagônico do risco de imagem ou reputação que é definido como (BANCO CENTRAL, 2005): “... é a possibilidade de que a publicidade negativa a respeito de uma agência, subsidiária ou da instituição financeira controladora, ocasione declínio na base de clientes ou redução das receitas." Ou, ainda, que "rumores maliciosos ou publicidade negativa podem gerar desconfiança em relação a um produto, ou à imagem global da instituição, e repercutir por muito tempo."

\section{Identificação do Contágio e Instituições Afetadas}

Gupta et. al. (2000, p. 21) analisaram dezesseis crises bancárias tendo por base um universo de 247 instituições, subdivididas e classificadas em cinco subconjuntos em ordem de rentabilidade crescente no período da crise. Constataram que os dois primeiros grupos concentraram a perda de rentabilidade, tiveram um aumento marcante de reservas e 
provisões para perdas de crédito, bem como apresentaram um declínio na relação Patrimônio Líquido/Ativos. Outro aspecto observado foi que os estoques de depósitos e de créditos tiveram redução substancialmente maior, da ordem de 15 a $20 \%$, enquanto na média da amostra não foi observada uma redução substancial dos depósitos. Essa distribuição indicaria um contágio localizado em determinadas instituições.

Com a intervenção no Banco Santos, o receio de ocorrência de outras insolvências propagou-se para outros agentes de mercado, ou mesmo para agentes que tiveram recursos retidos, que passaram a resgatar seus recursos. É difícil avaliar se ocorreu um movimento espontâneo de investidores que, dado o evento da intervenção, imediatamente estabeleceram uma possibilidade equivalente em relação a bancos congêneres (flight to quality) ou se tratou de mera resposta às opiniões dos agentes com maior credibilidade no mercado.

Aparentemente, uma das primeiras menções públicas ao possível contágio surgiu em 19/11/2004 (VALOR ECONÔMICO, 2004), em matéria sobre a interrupção da concessão de crédito por bancos pequenos e médios. A matéria destacava que "[...] as fundações, preocupadas com o ocorrido no Banco Santos, estão realizando saques em fundos e Certificados de Depósitos Bancários (CDBs) das instituições menores." A suspensão das concessões de novas operações, tema principal da matéria, seria preventiva para evitar a ocorrência de uma crise de liquidez. A preocupação das fundações estaria fundamentada, conforme esse mesmo texto, em:

[...] duas agências de classificação de risco de crédito consideradas pelo mercado, a Moodys e a Austin Asis concediam notas altas ao Banco Santos. A Moodys concedia nota "B1" para a dívida externa do Banco Santos, igual à do Governo Federal. No dia 9 de setembro, quando elevou a nota do Brasil, subiu junto a do Banco Santos. A Moodys só rebaixou a nota da instituição financeira para Caa3 (longo prazo em moeda estrangeira) e para Caa1 (moeda local) no dia 16 último, após a intervenção do BC. A Austin Asis dava nota "A" ao Banco Santos e à sua administradora de recursos a sexta melhor da sua escala.

\subsubsection{Identificação dos Bancos Contagiados}

Para a identificação dos bancos afetados pela intervenção no banco Santos, avaliou-se o comportamento do saldo da conta depósitos de todos os bancos da amostra selecionada. Foram definidos dois procedimentos complementares de análise:

- A análise gráfica qualitativa, a partir da qual procurou-se visualizar o comportamento dos depósitos. Para tal, os valores foram padronizados, adotando-se a data base janeiro de 2003, como referência com valor igual a 1 e, a partir dela, foram calculados 
os fatores de crescimento de cada banco da amostra. Os gráficos obtidos constam do Apêndice II, e os bancos foram agrupados, preferencialmente, pelo porte e pela própria característica do perfil gráfico.

- Cálculo das correlações estatísticas em três períodos de interesse: pré-crise, de jan. 2003 a set. 2004 e crise, de out. 2004 a mar. 2005 e de out. 2004 a set. 2005. Como o gráfico 1 já demonstrou uma perda de depósitos do Banco Santos em outubro de 2004, preferiu-se incluir esse mês nos períodos considerados de crise. Foram calculadas, utilizandose o software SPSS, as correlações entre os saldos das contas Depósitos de todos os bancos da amostra, entre si e com o saldo total da amostra. Os valores das correlações com o total da amostra estão no Apêndice I.

Por intermédio da análise de correlações estatísticas fica claro que, até a intervenção no Banco Santos, a maior parte dos bancos considerados vinha apresentando correlação elevada e significativa com o total da amostra. Após a intervenção, um grupo específico de bancos, pequenos e médios em sua maioria, deixou de apresentar correlação ou passou a apresentar correlação negativa com o total da amostra. Essa constatação, associada à ocorrência de inflexão no perfil gráfico do saldo da conta depósitos, permite caracterizar, em geral de forma contundente, um grupo de instituições cujo comportamento poderia ter sofrido o contágio da intervenção no Banco Santos. Esse grupo foi denominado Grupo de Estudo. As demais instituições da amostra foram aglutinadas em outros quatro grupos de acordo com o perfil de evolução dos saldos das contas de depósitos:

- Núcleo do Mercado: constituído pelos grandes bancos nacionais e por bancos cuja curva de crescimento dos depósitos apresentou boa aderência em relação ao total da amostra;

- Crescimento forte: bancos cuja curva de crescimento de depósitos apresentou crescimento acentuado e não correlacionado ao crescimento do grupo anterior;

- Baixa volatilidade: bancos para os quais não houve uma tendência definida de crescimento ou correlação com os grupos anteriores. Nesses casos, a evolução dos depósitos apresentou variabilidade, porém, sem grandes oscilações;

- Alta Volatilidade: bancos que, sem apresentarem tendência definida na curva de depósitos, mostraram elevada variabilidade no comportamento dessas curvas:

A composição de cada grupo está detalhada no quadro 1, a seguir. 
Quadro 1 - Definição de grupos de bancos

\begin{tabular}{|c|c|c|}
\hline \multicolumn{3}{|c|}{ Núcleo do Mercado } \\
\hline$\overline{\mathrm{ABN}}$ & Unibanco & $\overline{B E C}$ \\
\hline Bradesco & BB & BESC \\
\hline HSBC & $\mathrm{CEF}$ & $\mathrm{BRB}$ \\
\hline ITAU & Nossa Caixa & AJRenner \\
\hline Safra & Banestes & Cédula \\
\hline Santander Banespa & Banrisul & Rendimento \\
\hline \multicolumn{3}{|c|}{ Grupo de Estudo } \\
\hline$\overline{\text { Alfa }}$ & Ficsa & Pine \\
\hline BASA & Industrial do Brasil & Prosper \\
\hline $\mathrm{BIC}$ & Indusval & Rural \\
\hline $\mathrm{BMC}$ & Jmalucelli & Schahin \\
\hline $\mathrm{BMG}$ & Luso Brasileiro & Socopa \\
\hline Bonsucesso & Mercantil do Brasil & Sofisa \\
\hline Cruzeiro do Sul & Modal & SS \\
\hline Daycoval & Pecúnia & Triangulo \\
\hline \multicolumn{3}{|c|}{ Crescimento Forte } \\
\hline$\overline{\text { Banif }}$ & Daimler Chrysler & PSA Finance \\
\hline BES & Emblema & Toyota \\
\hline BGN & Honda & Votorantim \\
\hline Citibank & IBI & Ford \\
\hline \multicolumn{3}{|c|}{ Baixa volatilidade } \\
\hline ABC Brasil & Cacique & Guanabara \\
\hline AMEX & Cooperativo Sicredi & Morada \\
\hline BBM & Credibel & Pactual \\
\hline BankBoston & Dresdner & Societe General \\
\hline BNB & Fibra & Tricury \\
\hline Brascan & GMAC & Volkswagen \\
\hline \multicolumn{3}{|c|}{ Alta volatilidade } \\
\hline$\overline{\mathrm{ARBI}}$ & Deutsche & JPMorgan \\
\hline Cooperativo Brasil & Gerdau & Matone \\
\hline Credibel & ING & Rabobank \\
\hline Credit Suisse & Intercap & Tokio Mitsubishi \\
\hline
\end{tabular}

\subsection{Análise do Fenômeno}

\subsubsection{Virulência do Contágio}

No gráfico 3, foram lançados os valores acumulados dos depósitos das 24 instituições selecionadas para a análise. O perfil da curva demonstra não só a ocorrência do contágio, mas também a rapidez e virulência com que ele se estabeleceu. 
Gráfico 3 - Total de depósitos do Grupo de Estudo

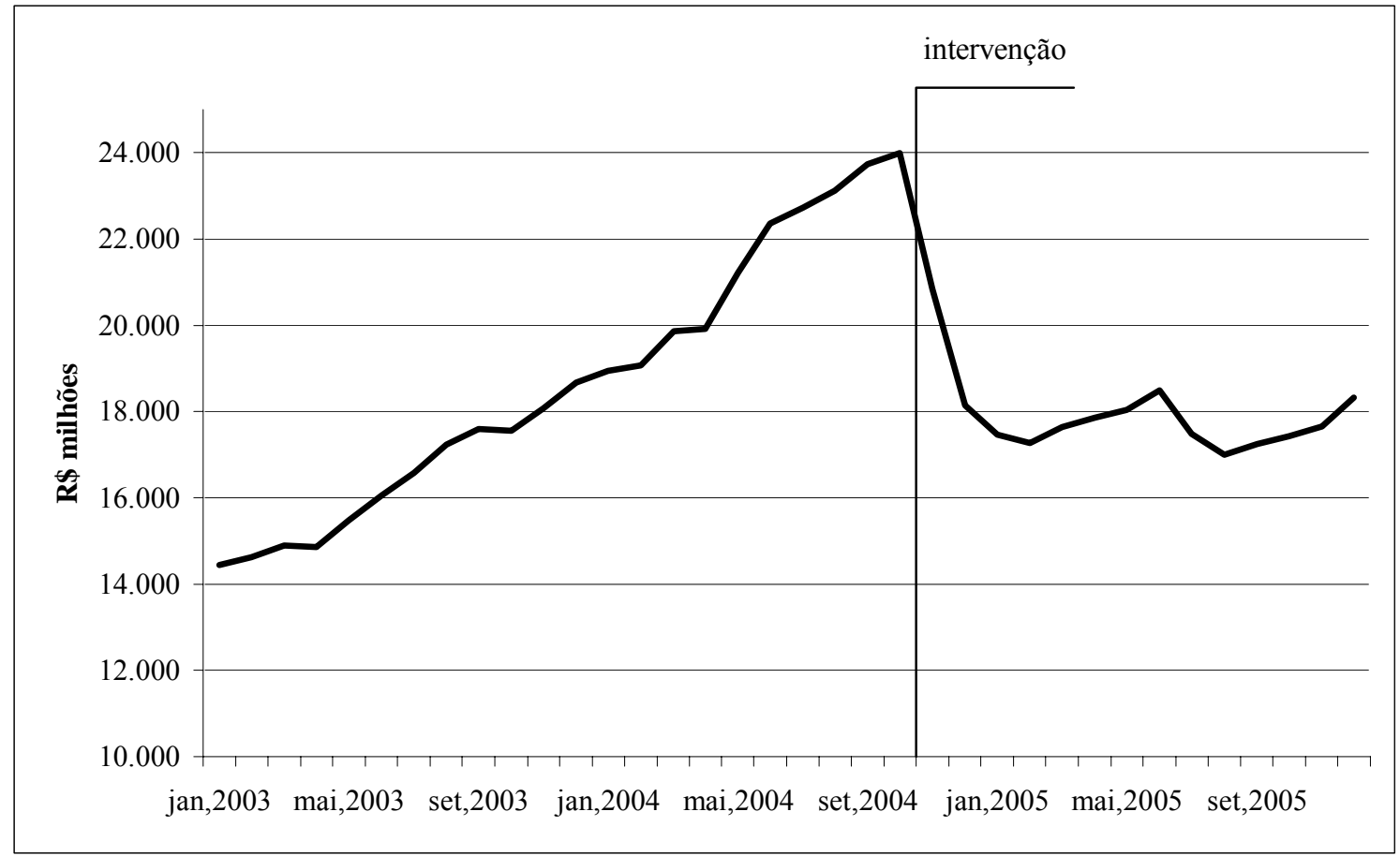

Ao longo de 2005, observa-se a obtenção de uma estabilidade. A recuperação observada não significou a retomada dos níveis de depósitos de setembro de 2004 para todas as instituições, conforme detalham as tabelas 6 e 7. 


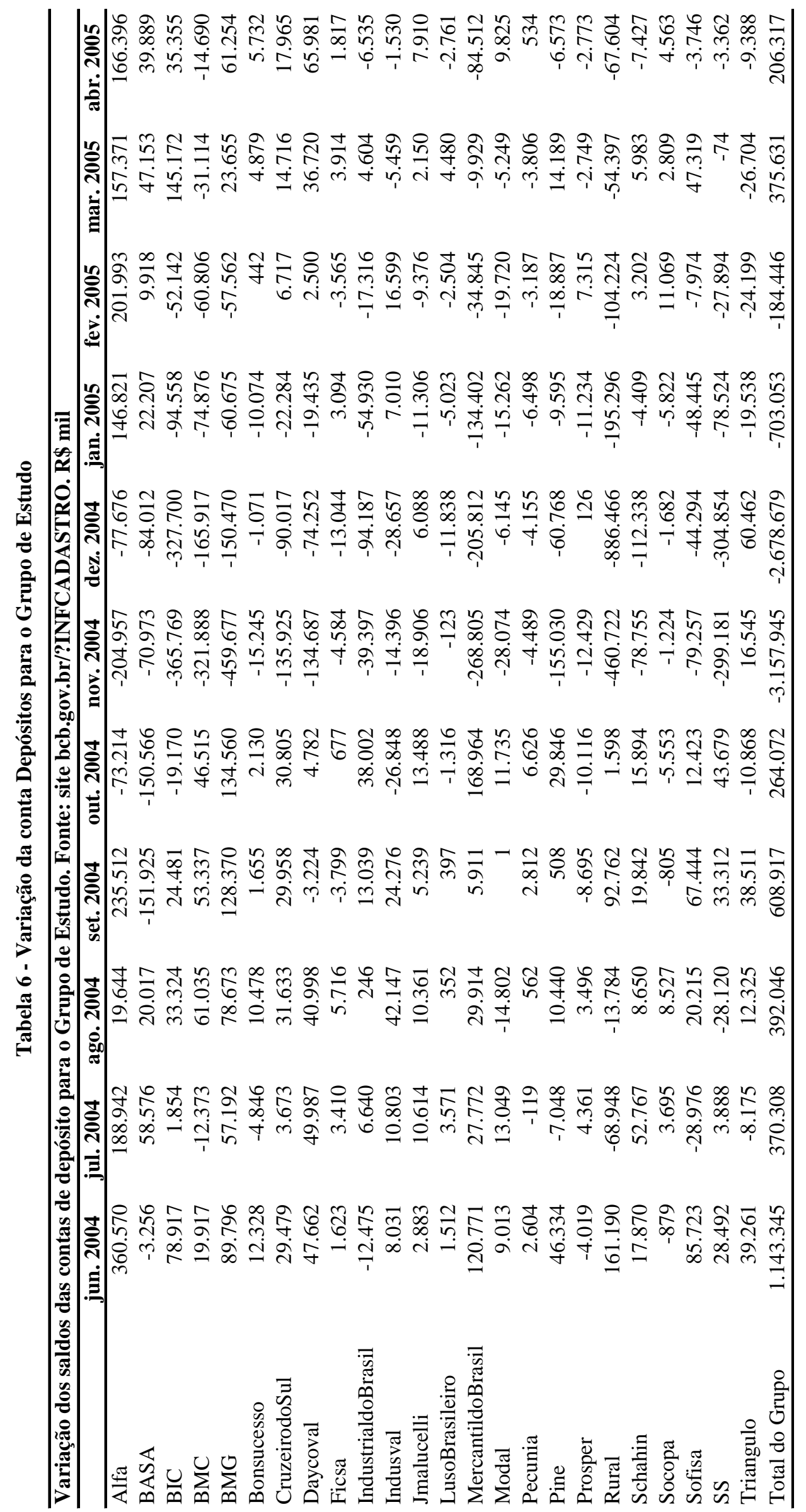




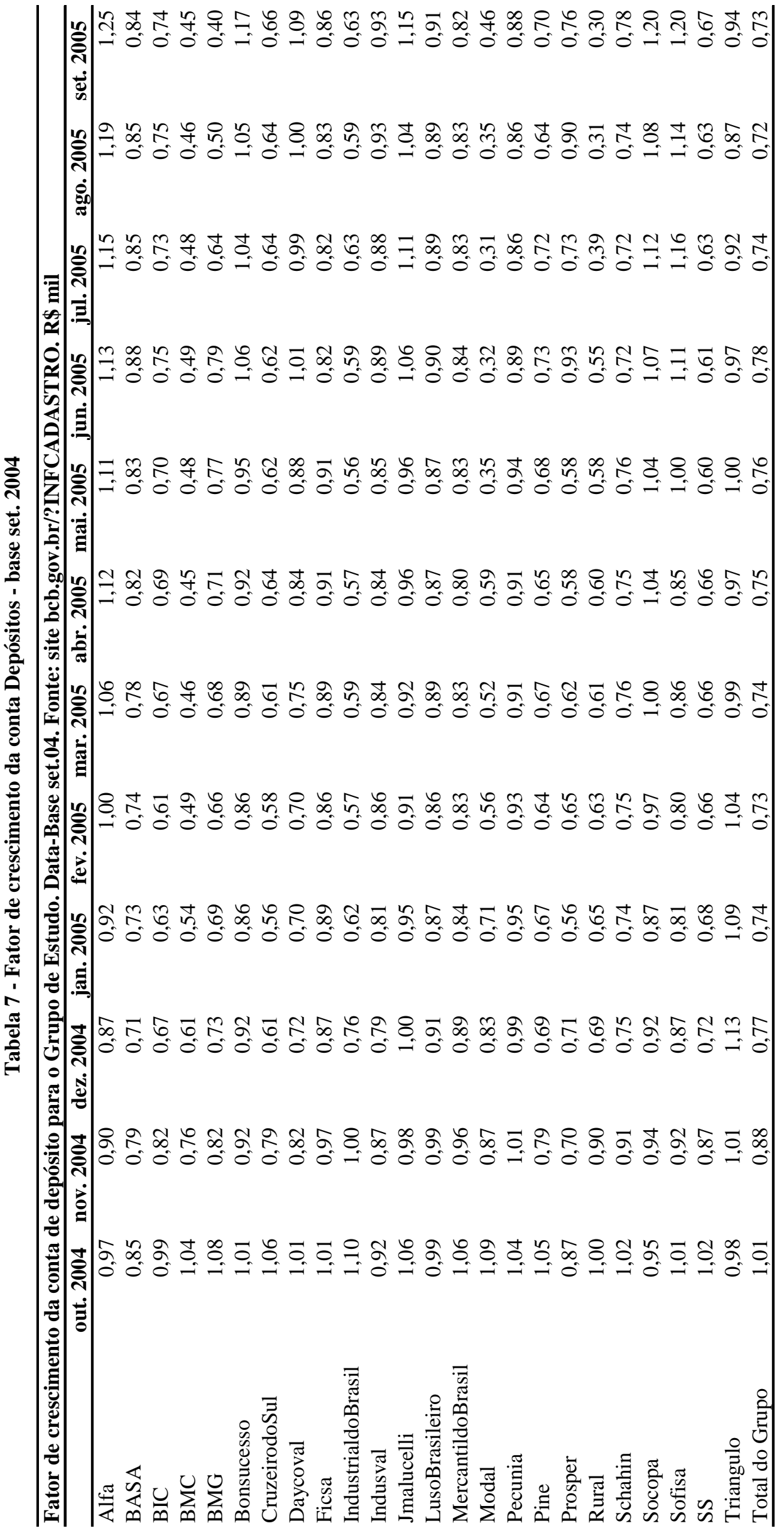


Destaque-se o Banco Rural que, embora não tenha voltado a registrar fluxo positivo, no período, vinha registrando uma redução dos saques e teve nova deterioração em sua situação, fruto da forte veiculação de sua imagem ao chamado "escândalo do mensalão"4.

\subsubsection{Perfil dos Depositantes}

A partir dos demonstrativos Informações Financeiras Trimestrais, extraídos para os 24 bancos do grupo de estudo, procurou-se avaliar o perfil de captação desse grupo de bancos e o comportamento após o evento da intervenção no Banco Santos. Os dados consolidados estão demonstrados na tabela 8 e gráficos subseqüentes.

Tabela 8 - Evolução dos saldos das contas Depósitos

\begin{tabular}{|c|c|c|c|c|c|c|c|c|c|}
\hline \multicolumn{10}{|c|}{ Saldos consolidados dos principais compone } \\
\hline & & A prazo & & & $\overline{\text { A vista }}$ & & & Poupança & \\
\hline & Governo & Juridica & Física & Governo & Juridica & Física & Governo & Juridica & Física \\
\hline mar,2004 & 111 & 13.560 & 3.262 & 41 & 900 & 250 & 0 & 38 & 357 \\
\hline jun,2004 & 154 & 14.973 & 3.513 & 33 & 1.109 & 274 & 1 & 50 & 354 \\
\hline set,2004 & 134 & 16.040 & 3.680 & 35 & 1.110 & 272 & 1 & 77 & 362 \\
\hline dez,2004 & 68 & 11.417 & 3.279 & 21 & 940 & 262 & 1 & 71 & 368 \\
\hline mar,2005 & 79 & 10.986 & 3.368 & 13 & 904 & 250 & 1 & 88 & 356 \\
\hline jun,2005 & 249 & 11.583 & 3.515 & 11 & 924 & 242 & 2 & 82 & 348 \\
\hline set,2005 & 246 & 10.888 & 3.372 & 9 & 838 & 241 & 3 & 66 & 330 \\
\hline dez,2005 & 187 & 11.710 & 3.518 & 11 & 889 & 255 & 9 & 78 & 336 \\
\hline
\end{tabular}

\footnotetext{
${ }^{4}$ Tratou-se de denúncia do ex-deputado Roberto Jefferson sobre esquema de pagamento a parlamentares para obter apoio nas votações do Congresso. A denúncia provocou a criação de Comissão Parlamentar de Inquérito e atribuiu-se ao Banco Rural papel importante como veículo para a transferência dos recursos, posteriormente designados como "recursos não contabilizados" dos partidos políticos, utilizados para o pagamento de dívidas de campanha.
} 
Gráfico 4 - Evolução Depósitos a Prazo

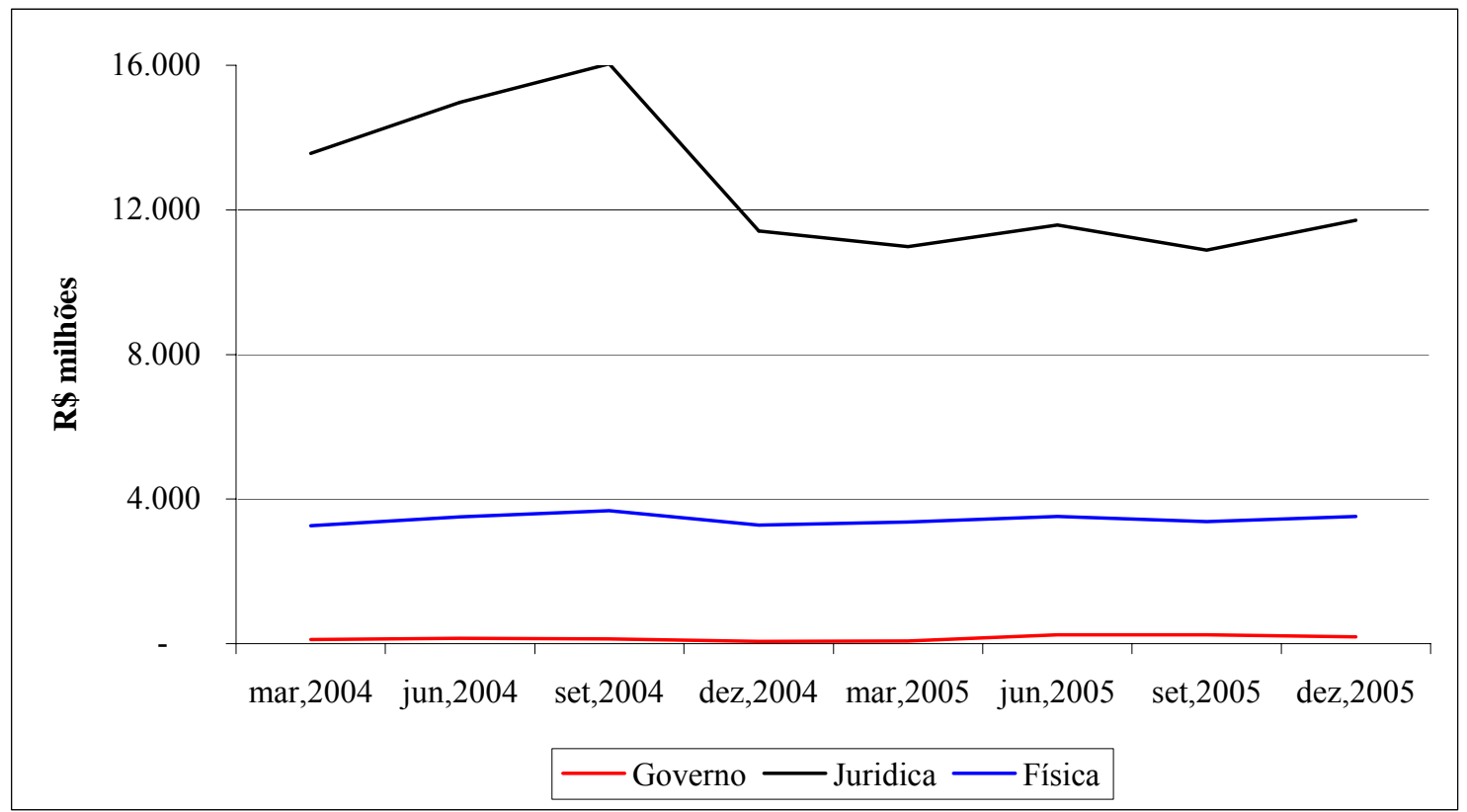

Gráfico 5 - Evolução Depósitos à Vista

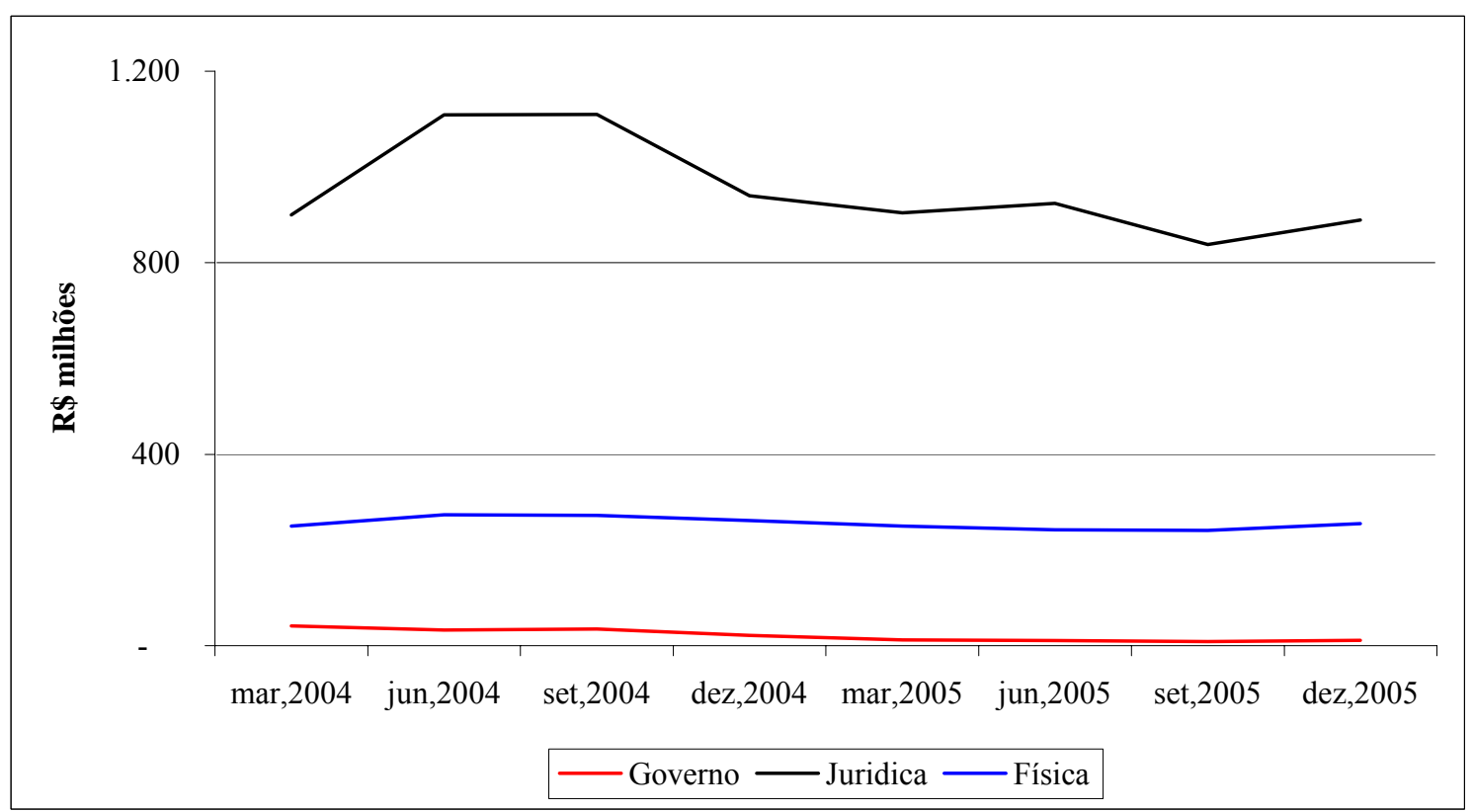


Gráfico 6 - Evolução Depósitos de Poupança

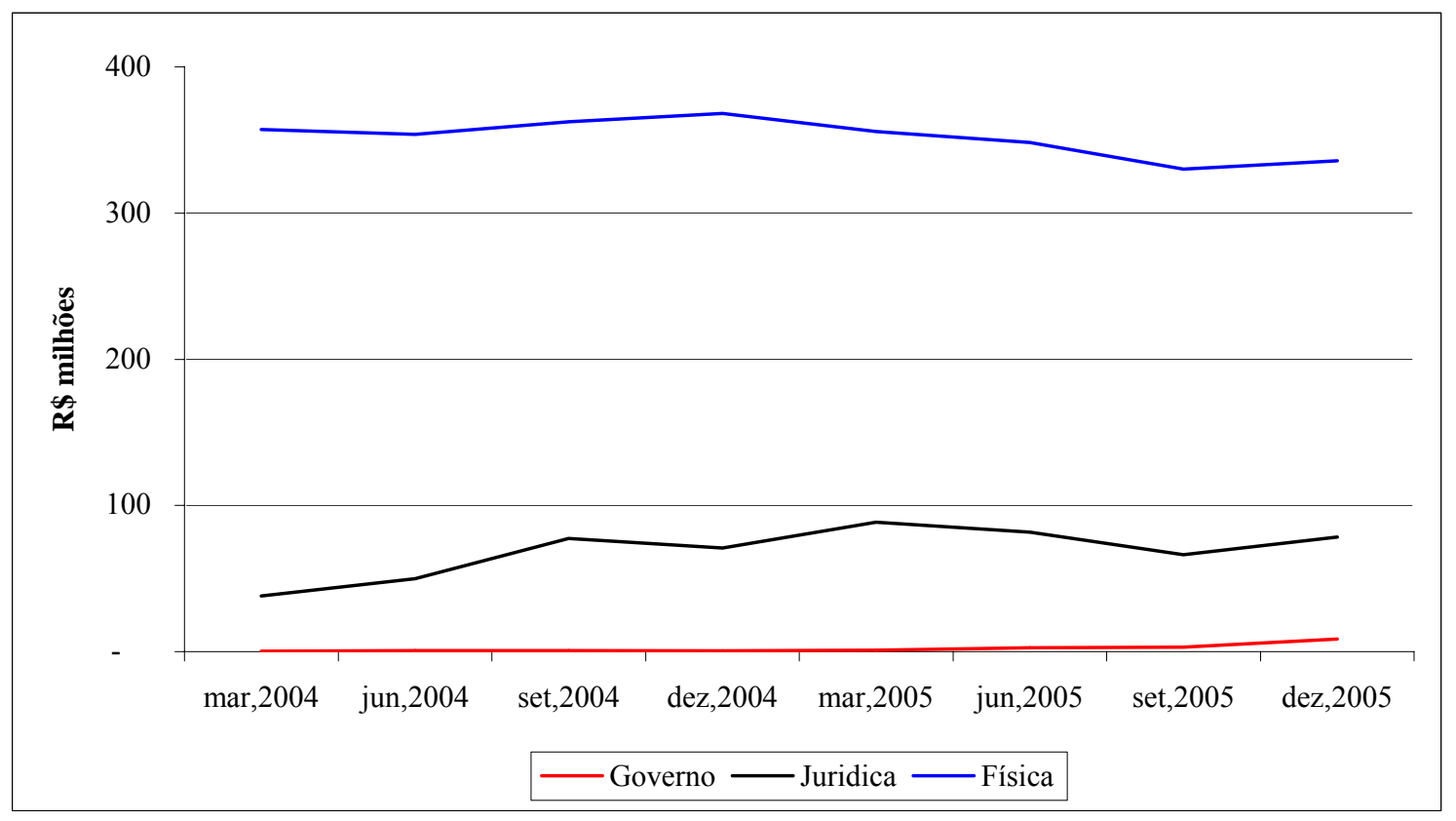

A conjunção da tabela 8 e dos três gráficos apresentados permite constatar que esse grupo de bancos tem nas pessoas jurídicas sua principal fonte de financiamento. E foi justamente esse aplicador que provocou a drenagem mais substantiva de recursos. O aplicador governamental é pouco representativo para essas instituições e para o cliente pessoa física, apesar de também apresentar uma redução dos saldos logo após a intervenção, verifica-se uma posterior recuperação e o retorno, em dezembro de 2005, ao nível do saldo consolidado de setembro de 2004.

Já para as pessoas jurídicas, após a queda brusca do último trimestre de 2004, o saldo permanece praticamente estagnado no restante do período analisado. Esse comportamento pode tanto indicar que não houve um pleno restabelecimento da confiança por parte desses depositantes em relação a essas instituições, o que teria caráter transitório, ou que critérios mais restritivos para o binômio risco-retorno foram adotados o que teria caráter permanente ou de prazo maior de duração. Essa última possibilidade seria mais afeita a investidores institucionais que, ante o evento, podem ter endurecido os normativos internos que definem os critérios de risco para a aplicação de recursos. 
Para um melhor estabelecimento dos mecanismos que as instituições atingidas utilizaram para enfrentar ou debelar a crise de confiança, é necessário conhecer as principais rubricas contábeis relacionadas com o risco de liquidez de curto prazo. O único item que merece uma maior consideração, tendo em vista tratar-se de um valor composto, é a liquidez que será aqui definida como o somatório dos seguintes saldos das contas do balancete contábil: Disponibilidades, Aplicações Interfinanceiras de Liquidez (subtraída do saldo da rubrica Operações Compromissadas - Carteira de Terceiros), Títulos Livres, Títulos Vinculados ao Banco Central e Créditos Vinculados.. As duas últimas rubricas correspondem aos recolhimentos compulsórios depositados no Banco Central, respectivamente, em títulos e em espécie.

A inclusão dos depósitos compulsórios como disponível, advém da percepção de que, numa situação de crise, o Banco Central teria um papel ativo visando debelá-la e a liberação desses compulsórios seria a ação mais imediata e de menor risco. Fernandez (1997, 28), em análise sobre a crise bancária da Argentina, no período de 1994 a 1995, concluiu que os depósitos à vista e depósitos a prazo de menor denominação, conjuntamente com as reservas compulsórias contribuíram para a manutenção da normalidade do sistema.

De fato, no presente caso, o Banco Central efetivamente liberou os recursos relativos ao depósito compulsório em títulos. A ação deu-se em 19.11.2004, sete dias após a intervenção, por meio da edição da Circular 3.262, que elevou a dedução do valor sujeito a recolhimento relativo aos depósitos a prazo de $\mathrm{R} \$ 30$ milhões para $\mathrm{R} \$ 300$ milhões (BANCO CENTRAL, 2005). Esse ato, na prática, representou a liberação integral dos saldos em títulos vinculados a esse depósito compulsório para a maior parte das instituições agrupadas no Grupo de Estudo. Dessa forma, o evento enfatiza a importância desse compulsório, estabelecido em $10 \%$ de uma base de cálculo que inclui os depósitos a prazos, como abastecedor de liquidez em situações de crise bancária.

Atualmente, a caracterização desse compulsório como instrumento de política monetária, seja para restringir a expansão das operações de crédito, seja para estabelecer uma demanda forçada para os títulos públicos (a chamada "cunha fiscal”), parece representar um papel subsidiário. O mercado bancário não só vem mantendo uma carteira de títulos substancialmente superior ao montante imposto pelos compulsórios mas também, a depender do momento econômico, os bancos são instados a expandir suas operações de crédito. A análise histórica demonstra, inclusive, que o rebaixamento da alíquota desses depósitos 
compulsórios nem sempre acarreta um aumento compatível no volume de crédito. Deve-se observar, porém, que em situações de volatilidade, esse recolhimento representa um fator de demanda compulsória para os títulos públicos o que atenua o potencial de deságio em seus preços.

\subsubsection{Estoque de Liquidez}

No gráfico 7, a seguir, foram lançados os resultados acumulados, mês a mês, dos itens de maior liquidez das instituições que compõem o Grupo de Estudo.

\section{Gráfico 7 - Evolução dos principais ativos e passivos de maior liquidez - Grupo de Estudo}

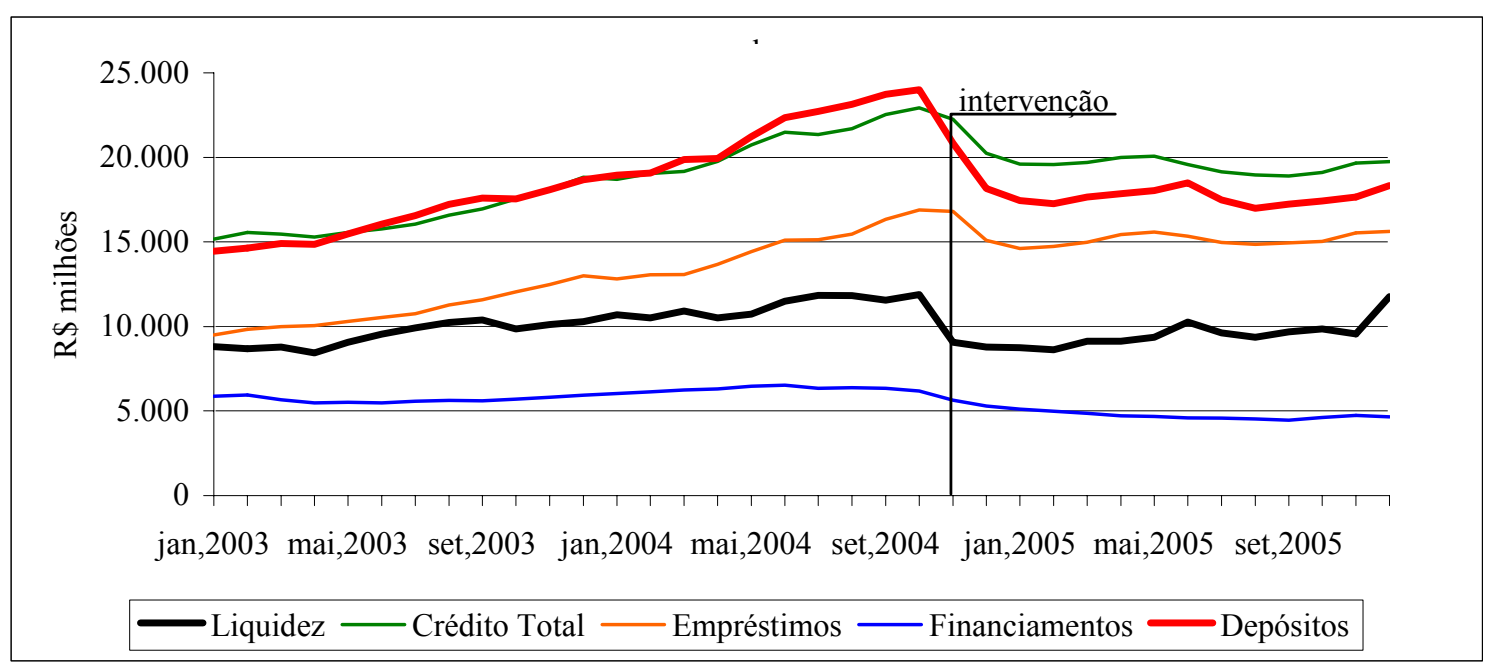

Observa-se de imediato, uma boa aderência entre os saldos de depósitos e de créditos concedidos. Essa constatação parece indicar uma característica do segmento: os recursos captados por meio de depósitos são aplicados em crédito e a atuação dessas instituições como intermediárias no repasse de financiamento de outras instituições é restrita, já que essa seria outra fonte de recursos para a carteira de crédito. Outra observação que o gráfico propicia é que, a partir do choque de desconfiança, o volume de depósitos passou a descrever uma trajetória abaixo dos saldos de crédito indicando que parte dessas operações passou a ser financiada com outras fontes de recursos. Significa dizer ainda que, para honrar a liquidação dos resgates de depósitos, os bancos, além de resgatar ou não renovar parte das carteiras de crédito, consumiram parte de sua liquidez.

Nota-se também, uma maior aproximação entre as trajetórias dos saldos dos depósitos e dos saldos dos empréstimos, possivelmente, fruto de uma estratégia de redução 
dos prazos de recebimento/renovação dos créditos, em detrimento da carteira de financiamentos.

Outro aspecto que merece destaque é o estoque e os componentes de liquidez, que certamente tem papel relevante no amortecimento de crises dessas magnitudes. $\mathrm{O}$ gráfico 8 e a tabela 9 detalham os principais componentes da liquidez.

Gráfico 8 - Evolução dos componentes de liquidez do Grupo de estudo

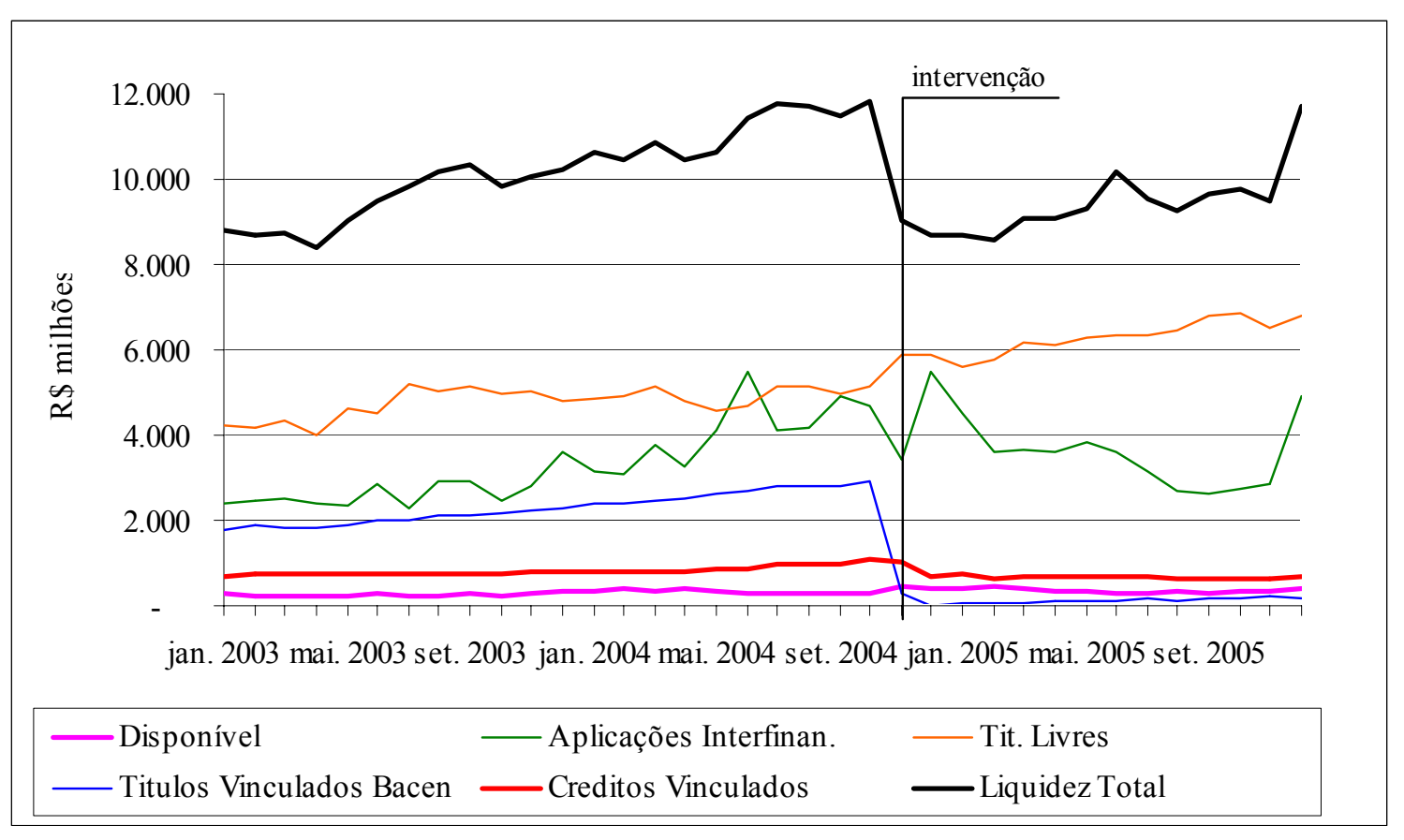


Tabela 9 - Evolução dos componentes da liquidez do Grupo de Estudo

\begin{tabular}{|c|c|c|c|c|c|c|c|}
\hline \multicolumn{8}{|c|}{ Fonte: site bcb.gov.br/?INFCADASTRO. R\$ milhões } \\
\hline & Disponível & $\begin{array}{l}\text { Aplicações } \\
\text { Interfinan. }\end{array}$ & Tit. Livres & $\begin{array}{l}\text { Titulos } \\
\text { Vinculados } \\
\text { Bacen } \\
\end{array}$ & $\begin{array}{c}\text { Creditos } \\
\text { Vinculados }\end{array}$ & $\begin{array}{l}\text { Obrig. } \\
\text { Carteira } \\
\text { Terceiros } \\
\end{array}$ & $\begin{array}{l}\text { Liquidez } \\
\text { Total }\end{array}$ \\
\hline jan. 2003 & 284 & 2.406 & 4.235 & 1.786 & 711 & 612 & 8.810 \\
\hline fev. 2003 & 208 & 2.456 & 4.192 & 1.866 & 717 & 746 & 8.692 \\
\hline mar. 2003 & 231 & 2.499 & 4.318 & 1.826 & 729 & 885 & 8.717 \\
\hline abr. 2003 & 202 & 2.423 & 4.008 & 1.817 & 754 & 829 & 8.375 \\
\hline mai. 2003 & 247 & 2.371 & 4.636 & 1.888 & 747 & 886 & 9.003 \\
\hline jun. 2003 & 277 & 2.885 & 4.498 & 1.973 & 719 & 884 & 9.467 \\
\hline jul. 2003 & 215 & 2.302 & 5.218 & 1.999 & 748 & 631 & 9.851 \\
\hline ago. 2003 & 234 & 2.929 & 5.017 & 2.126 & 735 & 862 & 10.179 \\
\hline set. 2003 & 267 & 2.936 & 5.125 & 2.142 & 718 & 846 & 10.342 \\
\hline out. 2003 & 254 & 2.445 & 4.948 & 2.195 & 726 & 759 & 9.808 \\
\hline nov. 2003 & 303 & 2.786 & 5.006 & 2.218 & 775 & 1.025 & 10.063 \\
\hline dez. 2003 & 338 & 3.580 & 4.780 & 2.285 & 803 & 1.545 & 10.241 \\
\hline jan. 2004 & 345 & 3.132 & 4.878 & 2.393 & 822 & 925 & 10.646 \\
\hline fev. 2004 & 391 & 3.094 & 4.933 & 2.375 & 791 & 1.135 & 10.449 \\
\hline mar. 2004 & 348 & 3.790 & 5.127 & 2.461 & 804 & 1.689 & 10.842 \\
\hline abr. 2004 & 408 & 3.280 & 4.813 & 2.492 & 820 & 1.377 & 10.435 \\
\hline mai. 2004 & 344 & 4.122 & 4.565 & 2.611 & 873 & 1.873 & 10.642 \\
\hline jun. 2004 & 293 & 5.500 & 4.702 & 2.696 & 884 & 2.661 & 11.413 \\
\hline jul. 2004 & 280 & 4.115 & 5.131 & 2.819 & 986 & 1.578 & 11.753 \\
\hline ago. 2004 & 294 & 4.147 & 5.168 & 2.800 & 998 & 1.671 & 11.736 \\
\hline set. 2004 & 297 & 4.920 & 4.980 & 2.813 & 987 & 2.517 & 11.480 \\
\hline out. 2004 & 268 & 4.687 & 5.126 & 2.908 & 1.066 & 2.247 & 11.808 \\
\hline nov. 2004 & 430 & 3.455 & 5.860 & 274 & 1.032 & 2.051 & 9.001 \\
\hline dez. 2004 & 392 & 5.479 & 5.887 & 25 & 680 & 3.758 & 8.705 \\
\hline jan. 2005 & 422 & 4.492 & 5.622 & 60 & 722 & 2.643 & 8.676 \\
\hline fev. 2005 & 449 & 3.578 & 5.771 & 66 & 655 & 1.963 & 8.556 \\
\hline mar. 2005 & 397 & 3.630 & 6.184 & 81 & 681 & 1.909 & 9.062 \\
\hline abr. 2005 & 359 & 3.597 & 6.098 & 96 & 675 & 1.768 & 9.057 \\
\hline mai. 2005 & 320 & 3.834 & 6.309 & 109 & 695 & 1.969 & 9.298 \\
\hline jun. 2005 & 301 & 3.626 & 6.339 & 125 & 680 & 877 & 10.195 \\
\hline jul. 2005 & 300 & 3.145 & 6.334 & 145 & 660 & 1.033 & 9.551 \\
\hline ago. 2005 & 364 & 2.704 & 6.466 & 133 & 608 & 992 & 9.284 \\
\hline set. 2005 & 299 & 2.656 & 6.823 & 158 & 603 & 902 & 9.638 \\
\hline out. 2005 & 357 & 2.733 & 6.861 & 189 & 612 & 965 & 9.786 \\
\hline nov. 2005 & 359 & 2.843 & 6.494 & 216 & 606 & 1.011 & 9.506 \\
\hline dez. 2005 & 394 & 4.931 & 6.815 & 191 & 670 & 1.304 & 11.697 \\
\hline
\end{tabular}

A rapidez de atuação do Banco Central dá bem a dimensão do risco potencial à liquidez das instituições atingidas. A missão do banco central é bem resumida em texto do Banco Mundial:

O governo ou o Banco Central, em geral, sai em socorro de qualquer banco que esteja sofrendo uma sangria de depósitos, com potencial para afetar o sistema de pagamentos. Isso ocorre mesmo que exista a suspeita de fraude ou de ação criminosa. A importância do sistema de pagamentos não permite esse tipo de juízo de valor. A questão da fraude deve ser tratada posteriormente. (WORLD BANK, 1997, p. 18). 
Contudo, apesar do relevante impacto em suas operações comerciais, as instituições analisadas conseguiram atender às solicitações de resgate de forma adequada. Essa ocorrência pode ser atribuída, em boa medida, a uma situação de liquidez relativamente confortável que essas instituições atingiram.

A preservação da liquidez parece ser o fato mais surpreendente do desenrolar dessa crise. Surpreende, principalmente, que ela derive, em boa medida, da cobrança dos créditos concedidos para pagamento dos depósitos. Era de se esperar que essa cobrança não fosse tão eficaz, dada a menor liquidez normalmente associada aos ativos de crédito. Não só isso aconteceu, como também a análise visual permite estabelecer que as curvas dos depósitos e das operações de crédito desenvolveram-se (declinaram) em movimento paralelo de boa correlação.

\subsection{2}

\section{Liquidação de Ativos}

Uma crise de liquidez é, normalmente, caracterizada pela impossibilidade de atender a uma demanda imprevista de recursos, seja pelo esgotamento dos recursos disponíveis ou de rápida conversibilidade, seja pela necessidade de converter ativos que tenham maior prazo de vencimento com perdas significativas. No caso das instituições financeiras brasileiras, os principais componentes de seus ativos são os títulos, em geral títulos públicos federais, que podem ser considerados de boa liquidez e as carteiras de crédito que, apenas recentemente, passaram a serem negociadas entre instituições financeiras, mediante análise criteriosa de suas composições ou então existência de coobrigação por parte da instituição cedente. Afora essa transação entre instituições financeiras, e a depender do volume necessário, pode-se considerar que esses créditos são, no curto prazo, de difícil realização.

Essa dificuldade deriva da própria essência do crédito, em especial do crédito às empresas. Essa circunstância é estabelecida de maneira bastante direta por Matarazzo:

\footnotetext{
O banqueiro no Brasil ignora, por conveniência ou desinteresse, que o financiamento do Ativo Circulante não é um dinheiro que se concede e se pede em devolução dentro de 30, 60 e 90 dias. E o empresário, salvo honrosas exceções ou aqueles bem assessorados, ingenuamente acredita que, pagando o empréstimo dentro de 30,60 ou 90 dias, está liquidando suas dívidas. Empréstimos bancários ou vêm para ficar ou é melhor não virem: eis um dos princípios da boa administração financeira. (2003, p.295).

A não renovação dos empréstimos bancários é uma autêntica "rasteira" na administração financeira da empresa. (2003, p.298).
} 
A gestão dos ativos de crédito no período de estudo pode ser avaliada por intermédio das tabelas 10 e 11 e do gráfico 9:

Tabela 10 - Evolução dos ativos de crédito - Grupo de Estudo

Saldos consolidados dos principais componentes das contas de operações de crédito do Grupo de Estudo IFTs. Fonte: https://www3.bcb.gov.br/iftimagem/. R\$ milhões

\begin{tabular}{rrrrrrrrr}
\hline \multicolumn{7}{c}{ Setor Privado } & \multicolumn{1}{c}{$\begin{array}{c}\text { Setor } \\
\text { Público }\end{array}$} \\
\hline Rural & Indústria & Comércio & Interm. Finan. & Serviços & Físicas & Habitação & 152 \\
mar/04 & 529 & 6.533 & 2.875 & 113 & 3.748 & 5.231 & 30 & 209 \\
jun/05 & 652 & 7.640 & 3.200 & 181 & 4.021 & 5.541 & 27 & 237 \\
set/05 & 700 & 7.861 & 3.418 & 155 & 4.267 & 5.928 & 34 & 234 \\
dez/05 & 682 & 6.637 & 3.130 & 231 & 3.931 & 5.385 & 37 & 271 \\
mar/05 & 618 & 6.523 & 2.832 & 228 & 3.718 & 5.493 & 30 & 287 \\
jun/05 & 670 & 6.367 & 2.947 & 268 & 3.759 & 5.540 & 23 & 251 \\
set/05 & 654 & 6.107 & 2.757 & 294 & 3.406 & 5.694 & 61 & 332 \\
dez/05 & 659 & 6.215 & 2.814 & 382 & 3.690 & 6.054 & 17 & \\
\hline
\end{tabular}

Tabela 11 - Fator de crescimento dos ativos de crédito - Grupo de Estudo

\begin{tabular}{|c|c|c|c|c|c|c|c|c|}
\hline & \multicolumn{7}{|c|}{ Setor Privado } & Setor \\
\hline & Rural & Indústria & Comércio & Interm. Finan. & Serviços & Físicas & Habitação & Público \\
\hline set/05 & 1,00 & 1,00 & 1,00 & 1,00 & 1,00 & 1,00 & 1,00 & 1,00 \\
\hline $\mathrm{dez} / 05$ & 0,98 & 0,84 & 0,92 & 1,49 & 0,92 & 0,91 & 1,09 & 0,99 \\
\hline $\operatorname{mar} / 05$ & 0,88 & 0,83 & 0,83 & 1,47 & 0,87 & 0,93 & 0,89 & 1,14 \\
\hline jun/05 & 0,96 & 0,81 & 0,86 & 1,73 & 0,88 & 0,93 & 0,67 & 1,21 \\
\hline set/05 & 0,94 & 0,78 & 0,81 & 1,90 & 0,80 & 0,96 & 1,79 & 1,06 \\
\hline $\mathrm{dez} / 05$ & 0,94 & 0,79 & 0,82 & 2,46 & 0,86 & 1,02 & 0,51 & 1,40 \\
\hline
\end{tabular}


Gráfico 9 - Evolução dos ativos de crédito do Grupo de Estudo

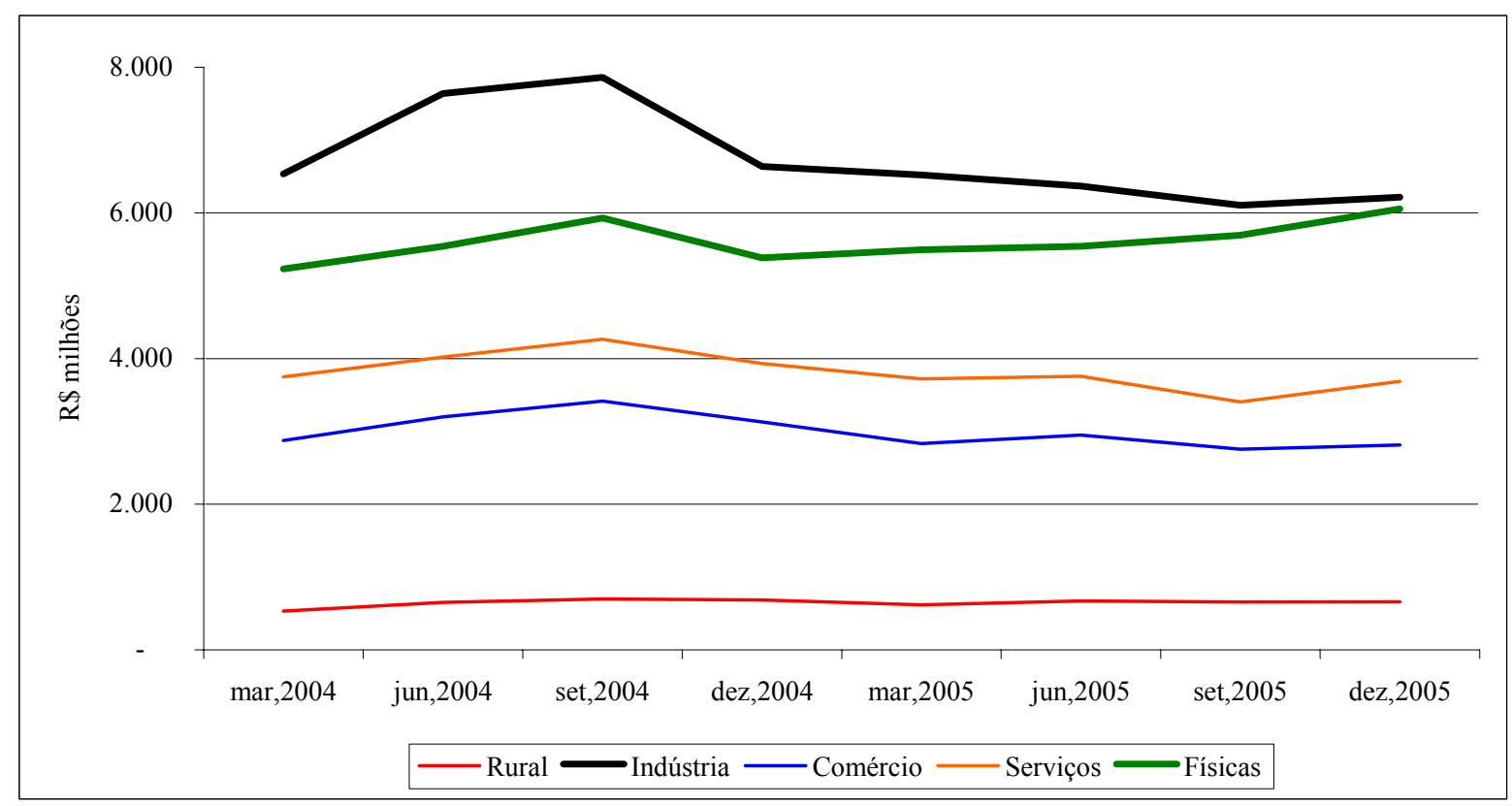

Verifica-se que os bancos que compõem o grupo de estudo foram bem sucedidos na realização dos créditos concedidos, em curto espaço de tempo. Confirma-se também que o impacto nas carteiras, representado pela redução dos saldos observados, foi bastante minimizado pela existência de um estoque de liquidez, com ênfase especial pelo estoque suplementar contido nos depósitos compulsórios, que foram imediatamente liberados.

Em particular, a tabela 11 permite constatar que, no último trimestre de 2004, a carteira de créditos para a indústria foi a principal provedora de recursos, tanto em termos absolutos como relativos, tendo sofrido uma perda de 14\% em relação ao saldo de setembro de 2004. Pode-se considerar que, posteriormente, a realização de ativos entre as demais carteiras relativas a pessoas jurídicas foi adquirindo comportamento homogêneo e, em dezembro de 2005, os saldos dessas carteiras para Indústria, Comércio e Serviços eram, respectivamente, de $79 \%, 82 \%$ e $86 \%$ dos saldos existentes em setembro de 2004 . Já o crédito para pessoas físicas tem um comportamento distinto. Sofre uma queda inicial, mas recuperase atingindo, ao final de 2005, o mesmo nível de setembro de 2004. Por tratar-se de carteira que, em geral, associa boa rentabilidade, boa liquidez e risco mediano, provavelmente sua manutenção ou mesmo expansão foi priorizada pelas instituições. Como panorama final, pode-se concluir que a crise ocasionada pela intervenção no Banco Santos, provocou não só uma redução dos créditos como também implicou numa mudança no perfil dessas carteiras que passaram a deter uma participação maior de pessoas físicas. 
A rápida liquidação dos créditos ativos não deixa de ser surpreendente frente aos registros bibliográficos que apontam que a realização de ativos de crédito em curto prazo, não só é difícil, como também pode acarretar perdas consideráveis. Uma hipótese alternativa seria a da cessão de parte dessas carteiras para os grandes bancos, que não foram afetados pela intervenção no Banco Santos. Essa hipótese é investigada por meio da consolidação dos dados relativos à cessão de créditos, constantes dos relatórios IFTs, na tabela 12 .

Tabela 12 - Total de créditos cedidos - Grupo de Estudo

\begin{tabular}{|c|c|c|c|}
\hline \multicolumn{4}{|c|}{$\begin{array}{l}\text { Saldos consolidados das cessões de crédito do Grupo de Estudo - IFTs. Fonte: } \\
\text { https://www3.bcb.gov.br/iftimagem/. R \$ mil }\end{array}$} \\
\hline \multicolumn{4}{|c|}{ Coobrigação } \\
\hline & com & sem & Total \\
\hline mar-04 & 326.269 & 54.031 & 380.300 \\
\hline jun-04 & 479.536 & 92.611 & 572.146 \\
\hline set-04 & 991.084 & 401.832 & 1.392 .916 \\
\hline dez-04 & 1.857 .651 & 923.598 & 2.781 .248 \\
\hline mar-05 & 2.271 .509 & 1.180 .026 & 3.451 .535 \\
\hline jun-05 & 2.846 .959 & 1.256 .064 & 4.103 .023 \\
\hline set-05 & 2.034.359 & 1.439 .305 & 3.473 .664 \\
\hline dez-05 & 1.798 .937 & 1.725 .217 & 3.524 .154 \\
\hline mar-06 & 2.343 .494 & 1.711 .338 & 4.054 .832 \\
\hline
\end{tabular}

De fato constata-se que, a partir de setembro de 2004, há um relevante crescimento das operações de cessão de créditos. Cumpre salientar que somente quatorze instituições do Grupo de Estudo tiveram registro de cessões a partir de setembro de 2004, o que significaria que nem todas as instituições utilizaram-se desse expediente.

Essa obtenção de liquidez por meio de cessões parece ter representado papel decisivo para debelar a crise conforme, mais recentemente, vem sendo comentado pela mídia:

- (Carvalho, 2006):

As cessões de carteiras de crédito ajudaram muitos bancos pequenos e médios a superar a crise de liquidez que atingiu o segmento após a quebra do Banco Santos, no final de 2004. Mas a contabilização dessas operações e seu uso intensivo para antecipar receitas e o impacto sobre a alavancagem preocupam a agência de avaliação de risco Fitch, que divulgou ontem um relatório a respeito.

A saída só foi possível graças à boa qualidade da carteira desses bancos. Foram objeto de cessão principalmente as carteiras de crédito consignado, empréstimo com desconto em folha para funcionário do setor público e privado e aposentados e beneficiários da Previdência Social operações de risco muito reduzido. 
-(Balarin, 2006):

Para os bancos menores, o CDB é uma das principais fontes de recursos. E os fundos de pensão, os maiores investidores. O problema é que o risco associado a essas instituições provocou uma debandada das fundações, que canalizaram seus recursos para bancos maiores ou até reduziram seus investimentos em CDB.

No médio prazo, outro efeito do recente aperto de liquidez poderá ser a alienação do controle acionário de algumas instituições de menor porte. "Poderemos assistir a uma nova rodada de concentração bancária no próximo ano, embora o gordo lucro de instituições nacionais de varejo esteja aguçando a vontade dos estrangeiros", afirma um consultor da área de bancos. Ele ressalta que as recentes cessões de crédito tiveram um impacto positivo no resultado das instituições de menor porte porque, na venda da carteira, é apropriada de cara a receita total do contrato, com antecipação do spread

- (Garrido, 2006)

Foram, aliás, os bancos de menor porte - como BMG, Cruzeiro do Sul, Cacique, BGN, Bonsucesso, Pine, Schahin e Paranabanco - os que roubaram a cena, no começo. Os grandes só entraram para valer no consignado após o escândalo do Banco Santos, no fim de 2004. O episódio arranhou a credibilidade dos bancos de pequeno e médio porte, provocando a migração de depósitos a prazo para os grandes.

Sem fôlego, as instituições menores tiveram dificuldades para seguir bancando as operações consignadas. Com isso, gigantes como Bradesco, Itaú, Unibanco, Santander e HSBC passaram a comprar créditos dos concorrentes sufocados. Por essas operações de cessão de carteira, os grandes garantem o funding e os pequenos e médios entram com sua capacidade de conquistar empregados da ativa e aposentados e pensionistas do INSS.

Confirma-se, portanto, que a cessão de créditos representou papel fundamental para o fornecimento de liquidez aos bancos contagiados pela intervenção no Banco Santos. Não há portanto uma contradição em relação à fundamentação teórica que dá a carteira de crédito como um ativo de difícil liquidação em prazos curtos ou médios.

Surge apenas uma aparente contradição sobre a questão no tipo de crédito objeto de cessão. As notas de imprensa apresentadas destacam como principais carteiras cedidas os empréstimos a pessoas físicas (crédito consignado). De fato, no período imediatamente posterior à intervenção no banco Santos, foram divulgados diversos acordos operacionais entre bancos pequenos e médios e bancos grandes para a cessão de créditos dessa natureza e isso explicaria a recomposição dessas carteiras, ao final de 2005, aos níveis de setembro de 2004. Contudo, conforme descrito anteriormente, os dados consolidados relativos aos demonstrativos IFTs indicam que a recuperação mais relevante de liquidez proveio da carteira de crédito de pessoas jurídicas.

Configura-se, portanto, um cenário que combinou a utilização de liquidez própria, de liquidez oriunda de depósitos compulsórios, da cessão de créditos e até da liquidação de parte das carteiras de crédito, com uma mudança de perfil da carteira de créditos e nítido crescimento da participação dos créditos com pessoas físicas. Nesse contexto, torna-se 
interessante avaliar o impacto que essas modificações impuseram ao resultado operacional dos bancos. Para tanto, foram conduzidos testes das diferenças das médias, para os grupos de Estudo e Núcleo do Mercado, em relação a três indicadores contábeis definidos como:

Provisão $=\frac{\text { Provisão sobre Operações de Crédito }}{(\text { Saldo de Oper. de Crédito mês } i+\text { Saldo de Oper. de Crédito mês } i+1)}$

Juros passivo $=\frac{\text { Despesas de Captação }- \text { Obrigações Compromissadas xTaxa Selic }}{\text { Depósitos }+ \text { Recursos Ac. Cambiais, Letras Imobil., Debêntures e similares }}$

Jurosativo $=\frac{\text { Rendas de Operações de Crédito }}{\text { Operações de Crédito }}$

Esses resultados abrangem todo o período da análise e estão consignados nas tabelas 13 a 18. Para a confecção dessas tabelas foram suprimidas as informações dos bancos que mostraram comportamento nitidamente descolado do padrão geral dos respectivos grupos. Essas informações foram tratadas como outliers. 
Tabela 13 - Teste da diferença das médias para a variável Jurosativo

Teste de igualdade das médias da variável Jurosativo entre os grupos: Núcleo do Mercado e de Estudo. Foram excluidos da análise os bancos: Bonsucesso, Cruzeiro do Sul e SS por configurarem outliers. Fonte dos dados: balancetes mensais do site www.bcb.gov.br

\begin{tabular}{|c|c|c|c|c|c|c|c|c|}
\hline & \multicolumn{3}{|c|}{$\begin{array}{l}\text { Teste de Levene - igualdade de } \\
\text { Variâncias }\end{array}$} & \multicolumn{5}{|c|}{ Teste-t para igualdade das médias } \\
\hline & & $\mathrm{F}$ & Sig. & $\mathrm{t}$ & df & $\begin{array}{c}\text { Signif. } \\
\text { bicaudal }\end{array}$ & Diferença & Erro padrão \\
\hline \multirow{2}{*}{ fev. 2003} & $*$ & 1,1000 & 0,3011 & $-0,488$ & 37,00 & 0,628 & $-0,001$ & 0,003 \\
\hline & $* *$ & & & $-0,503$ & 35,11 & 0,618 & $-0,001$ & 0,003 \\
\hline \multirow{2}{*}{ mar. 2003} & $*$ & 3,3599 & 0,0749 & 0,136 & 37,00 & 0,893 & 0,001 & 0,005 \\
\hline & $* *$ & & & 0,141 & 33,34 & 0,889 & 0,001 & 0,004 \\
\hline \multirow{2}{*}{ abr. 2003} & $*$ & 1,1091 & 0,2991 & $-1,186$ & 37,00 & 0,243 & $-0,007$ & 0,006 \\
\hline & $* *$ & & & $-1,227$ & 34,30 & 0,228 & $-0,007$ & 0,006 \\
\hline \multirow{2}{*}{ mai. 2003} & $*$ & 0,7409 & 0,3949 & $-0,313$ & 37,00 & 0,756 & $-0,001$ & 0,003 \\
\hline & $* *$ & & & $-0,321$ & 35,65 & 0,750 & $-0,001$ & 0,003 \\
\hline \multirow{2}{*}{ jun. 2003} & $*$ & 2,0100 & 0,1646 & $-1,118$ & 37,00 & 0,271 & $-0,005$ & 0,005 \\
\hline & $* *$ & & & $-1,165$ & 32,21 & 0,252 & $-0,005$ & 0,004 \\
\hline \multirow{2}{*}{ jul. 2003} & $*$ & 0,9825 & 0,3280 & $-0,868$ & 37,00 & 0,391 & $-0,003$ & 0,004 \\
\hline & $* *$ & & & $-0,897$ & 34,54 & 0,376 & $-0,003$ & 0,003 \\
\hline \multirow{2}{*}{ ago. 2003} & $*$ & 1,1594 & 0,2886 & $-0,589$ & 37,00 & 0,559 & $-0,002$ & 0,004 \\
\hline & $* *$ & & & $-0,605$ & 35,66 & 0,549 & $-0,002$ & 0,003 \\
\hline \multirow{2}{*}{ set. 2003} & $*$ & 2,0363 & 0,1620 & $-0,783$ & 37,00 & 0,439 & $-0,003$ & 0,004 \\
\hline & $* *$ & & & $-0,814$ & 32,72 & 0,421 & $-0,003$ & 0,004 \\
\hline \multirow{2}{*}{ out. 2003} & $*$ & 0,4466 & 0,5081 & $-0,626$ & 37,00 & 0,535 & $-0,002$ & 0,004 \\
\hline & $* *$ & & & $-0,643$ & 35,76 & 0,524 & $-0,002$ & 0,004 \\
\hline \multirow{2}{*}{ nov. 2003} & $*$ & 0,5069 & 0,4809 & $-0,288$ & 37,00 & 0,775 & $-0,001$ & 0,004 \\
\hline & $* *$ & & & $-0,291$ & 36,96 & 0,773 & $-0,001$ & 0,004 \\
\hline \multirow{2}{*}{ dez. 2003} & $*$ & 2,5456 & 0,1191 & $-0,842$ & 37,00 & 0,405 & $-0,004$ & 0,004 \\
\hline & $* *$ & & & $-0,875$ & 33,23 & 0,388 & $-0,004$ & 0,004 \\
\hline \multirow{2}{*}{ jan. 2004} & $*$ & 1,7999 & 0,1879 & $-0,491$ & 37,00 & 0,626 & $-0,002$ & 0,003 \\
\hline & $* *$ & & & $-0,505$ & 35,43 & 0,617 & $-0,002$ & 0,003 \\
\hline \multirow{2}{*}{ fev. 2004} & $*$ & 2,4977 & 0,1225 & $-0,229$ & 37,00 & 0,820 & $-0,001$ & 0,003 \\
\hline & $* *$ & & & $-0,238$ & 33,11 & 0,813 & $-0,001$ & 0,003 \\
\hline \multirow{2}{*}{ mar. 2004} & $*$ & 2,1731 & 0,1489 & $-0,402$ & 37,00 & 0,690 & $-0,001$ & 0,004 \\
\hline & $* *$ & & & $-0,417$ & 33,64 & 0,680 & $-0,001$ & 0,003 \\
\hline \multirow{2}{*}{ abr. 2004} & $*$ & 1,6855 & 0,2022 & $-0,130$ & 37,00 & 0,897 & 0,000 & 0,003 \\
\hline & $* *$ & & & $-0,134$ & 35,09 & 0,894 & 0,000 & 0,003 \\
\hline \multirow{2}{*}{ mai. 2004} & $*$ & 2,1160 & 0,1542 & $-0,192$ & 37,00 & 0,849 & $-0,001$ & 0,003 \\
\hline & $* *$ & & & $-0,200$ & 32,76 & 0,843 & $-0,001$ & 0,003 \\
\hline \multirow{2}{*}{ jun. 2004} & $*$ & 5,1873 & 0,0286 & $-1,120$ & 37,00 & 0,270 & $-0,004$ & 0,004 \\
\hline & $* *$ & & & $-1,169$ & 31,87 & 0,251 & $-0,004$ & 0,003 \\
\hline
\end{tabular}


Tabela 14 - Teste da diferença das médias para a variável Jurosativo. Cont. Tab 13

Teste de igualdade das médias da variável Jurosativo entre os grupos: Núcleo do Mercado e de Estudo. Foram excluidos da análise os bancos: Bonsucesso, Cruzeiro do Sul e SS por configurarem outliers. Fonte dos dados: balancetes mensais do site www.bcb.gov.br

\begin{tabular}{|c|c|c|c|c|c|c|c|c|}
\hline & \multicolumn{3}{|c|}{$\begin{array}{l}\text { Teste de Levene - igualdade de } \\
\text { Variâncias }\end{array}$} & \multicolumn{5}{|c|}{ Teste-t para igualdade das médias } \\
\hline & & $\mathrm{F}$ & Sig. & $\mathrm{t}$ & $\mathrm{df}$ & $\begin{array}{l}\text { Signif. } \\
\text { bicaudal }\end{array}$ & Diferença & Erro padrão \\
\hline \multirow{2}{*}{ jul. 2004} & $*$ & 2,0333 & 0,1623 & $-0,479$ & 37,00 & 0,635 & $-0,002$ & 0,003 \\
\hline & $* *$ & & & $-0,493$ & 35,37 & 0,625 & $-0,002$ & 0,003 \\
\hline \multirow{2}{*}{ ago. 2004} & $*$ & 4,1109 & 0,0499 & $-1,028$ & 37,00 & 0,311 & $-0,004$ & 0,004 \\
\hline & $* *$ & & & $-1,076$ & 30,64 & 0,290 & $-0,004$ & 0,004 \\
\hline \multirow{2}{*}{ set. 2004} & $*$ & 1,0306 & 0,3166 & $-0,226$ & 37,00 & 0,823 & $-0,001$ & 0,003 \\
\hline & $* *$ & & & $-0,234$ & 33,94 & 0,817 & $-0,001$ & 0,003 \\
\hline \multirow{2}{*}{ out. 2004} & $*$ & 2,5846 & 0,1164 & $-0,213$ & 37,00 & 0,833 & $-0,001$ & 0,003 \\
\hline & $* *$ & & & $-0,221$ & 32,55 & 0,826 & $-0,001$ & 0,003 \\
\hline \multirow{2}{*}{ nov. 2004} & $*$ & 2,3491 & 0,1339 & $-0,627$ & 37,00 & 0,534 & $-0,002$ & 0,003 \\
\hline & $* *$ & & & $-0,653$ & 32,35 & 0,518 & $-0,002$ & 0,003 \\
\hline \multirow{2}{*}{ dez. 2004} & $*$ & 10,2414 & 0,0028 & $-1,767$ & 37,00 & 0,085 & $-0,010$ & 0,006 \\
\hline & $* *$ & & & $-1,887$ & 24,33 & 0,071 & $-0,010$ & 0,006 \\
\hline \multirow{2}{*}{ jan. 2005} & $*$ & 2,8039 & 0,1025 & $-1,044$ & 37,00 & 0,303 & $-0,006$ & 0,005 \\
\hline & $* *$ & & & $-1,112$ & 25,01 & 0,277 & $-0,006$ & 0,005 \\
\hline \multirow{2}{*}{ fev. 2005} & $*$ & 7,4228 & 0,0098 & $-1,200$ & 37,00 & 0,238 & $-0,004$ & 0,003 \\
\hline & $* *$ & & & $-1,263$ & 29,00 & 0,217 & $-0,004$ & 0,003 \\
\hline \multirow{2}{*}{ mar. 2005} & $*$ & 5,4987 & 0,0245 & $-1,835$ & 37,00 & 0,075 & $-0,007$ & 0,004 \\
\hline & $* *$ & & & $-1,937$ & 28,07 & 0,063 & $-0,007$ & 0,004 \\
\hline \multirow{2}{*}{ abr. 2005} & $*$ & 3,2477 & 0,0797 & $-0,984$ & 37,00 & 0,332 & $-0,004$ & 0,004 \\
\hline & $* *$ & & & $-1,024$ & 32,75 & 0,314 & $-0,004$ & 0,003 \\
\hline \multirow{2}{*}{ mai. 2005} & $*$ & 6,8246 & 0,0129 & $-1,515$ & 37,00 & 0,138 & $-0,006$ & 0,004 \\
\hline & $* *$ & & & $-1,590$ & 30,06 & 0,122 & $-0,006$ & 0,004 \\
\hline \multirow{2}{*}{ jun. 2005} & $*$ & 16,5285 & 0,0002 & $-2,519$ & 37,00 & 0,016 & $-0,011$ & 0,004 \\
\hline & $* *$ & & & $-2,672$ & 26,42 & 0,013 & $-0,011$ & 0,004 \\
\hline \multirow{2}{*}{ jul. 2005} & $*$ & 6,7398 & 0,0134 & $-1,498$ & 37,00 & 0,143 & $-0,005$ & 0,003 \\
\hline & $* *$ & & & $-1,565$ & 31,61 & 0,128 & $-0,005$ & 0,003 \\
\hline \multirow{2}{*}{ ago. 2005} & $*$ & 4,9834 & 0,0317 & $-0,894$ & 37,00 & 0,377 & $-0,007$ & 0,008 \\
\hline & $* *$ & & & $-0,934$ & 31,60 & 0,357 & $-0,007$ & 0,008 \\
\hline \multirow{2}{*}{ set. 2005} & $*$ & 2,9427 & 0,0946 & $-1,078$ & 37,00 & 0,288 & $-0,005$ & 0,005 \\
\hline & $* *$ & & & $-1,119$ & 33,29 & 0,271 & $-0,005$ & 0,005 \\
\hline \multirow{2}{*}{ out. 2005} & $*$ & 4,1943 & 0,0477 & $-1,263$ & 37,00 & 0,215 & $-0,005$ & 0,004 \\
\hline & $* *$ & & & $-1,336$ & 27,25 & 0,192 & $-0,005$ & 0,004 \\
\hline \multirow{2}{*}{ nov. 2005} & $*$ & 6,1203 & 0,0181 & $-1,311$ & 37,00 & 0,198 & $-0,005$ & 0,004 \\
\hline & $* *$ & & & $-1,386$ & 27,72 & 0,177 & $-0,005$ & 0,004 \\
\hline \multirow{2}{*}{ dez. 2005} & $*$ & 13,8343 & 0,0007 & $-2,036$ & 37,00 & 0,049 & $-0,012$ & 0,006 \\
\hline & $* *$ & & & $-2,178$ & 23,54 & 0,040 & $-0,012$ & 0,005 \\
\hline
\end{tabular}

O indicador Jurosativo, tabelas 13 e 14, procura representar, por meio de dados contábeis, a diferença de rentabilidade média mensal entre as carteiras de crédito do Grupo Núcleo de Mercado e Grupo de Estudo. Os resultados mostram que, ao longo de todo o período analisado, essa diferença não é significativamente diferente de zero indicando que a média de juros praticados pelos dois grupos era equivalente. Verifica-se, porém, a partir de 
dezembro de 2004, um aumento na variância dos valores do Grupo de Estudo tornando as variâncias dos dois grupos significativamente diferentes. A análise dos dados individuais demonstra um aumento no valor do indicador para algumas instituições do Grupo de Estudo.

Tabela 15 - Teste da diferença das médias para a variável Provisão

Teste de igualdade das médias da variável Provisão entre os grupos: Núcleo do Mercado e de Estudo.

Foram excluidos da análise os bancos: BASA, Banrisul, Rural, CEF e BESC, por configurarem outliers.

Fonte dos dados: balancetes mensais do site www.bcb.gov.br

\begin{tabular}{|c|c|c|c|c|c|c|c|c|}
\hline & \multicolumn{3}{|c|}{$\begin{array}{l}\text { Teste de Levene - igualdade de } \\
\text { Variâncias }\end{array}$} & \multicolumn{5}{|c|}{ Teste-t para igualdade das médias } \\
\hline & & $\mathrm{F}$ & Sig. & $\mathrm{t}$ & $\mathrm{df}$ & $\begin{array}{l}\text { Signif. } \\
\text { bicaudal }\end{array}$ & Diferença & Erro padrão \\
\hline \multirow{2}{*}{ fev. 2003} & $*$ & 0,0097 & 0,9221 & 1,650 & 35,00 & 0,108 & 0,021 & 0,013 \\
\hline & $* *$ & & & 1,676 & 31,79 & 0,104 & 0,021 & 0,013 \\
\hline \multirow{2}{*}{ mar. 2003} & $*$ & 0,0018 & 0,9667 & 1,642 & 35,00 & 0,110 & 0,022 & 0,013 \\
\hline & $* *$ & & & 1,688 & 32,90 & 0,101 & 0,022 & 0,013 \\
\hline \multirow{2}{*}{ abr. 2003} & $*$ & 0,3447 & 0,5609 & 1,275 & 35,00 & 0,211 & 0,017 & 0,014 \\
\hline & $* *$ & & & 1,330 & 33,95 & 0,193 & 0,017 & 0,013 \\
\hline \multirow{2}{*}{ mai. 2003} & $*$ & 0,8285 & 0,3689 & 1,025 & 35,00 & 0,312 & 0,014 & 0,013 \\
\hline & $* *$ & & & 1,097 & 34,97 & 0,280 & 0,014 & 0,012 \\
\hline \multirow{2}{*}{ jun. 2003} & $*$ & 0,2550 & 0,6167 & 1,536 & 35,00 & 0,134 & 0,018 & 0,012 \\
\hline & $* *$ & & & 1,598 & 33,78 & 0,119 & 0,018 & 0,011 \\
\hline \multirow{2}{*}{ jul. 2003} & $*$ & 0,6033 & 0,4425 & 1,365 & 35,00 & 0,181 & 0,016 & 0,012 \\
\hline & $* *$ & & & 1,429 & 34,21 & 0,162 & 0,016 & 0,011 \\
\hline \multirow{2}{*}{ ago. 2003} & $*$ & 0,9633 & 0,3331 & 1,242 & 35,00 & 0,223 & 0,015 & 0,012 \\
\hline & $* *$ & & & 1,313 & 34,67 & 0,198 & 0,015 & 0,011 \\
\hline \multirow{2}{*}{ set. 2003} & $*$ & 0,2226 & 0,6400 & 2,002 & 35,00 & 0,053 & 0,022 & 0,011 \\
\hline & $* *$ & & & 2,083 & 33,78 & 0,045 & 0,022 & 0,011 \\
\hline \multirow{2}{*}{ out. 2003} & $*$ & 0,3223 & 0,5739 & 2,155 & 35,00 & 0,038 & 0,023 & 0,011 \\
\hline & $* *$ & & & 2,253 & 34,09 & 0,031 & 0,023 & 0,010 \\
\hline \multirow{2}{*}{ nov. 2003} & $*$ & 0,3208 & 0,5747 & 2,077 & 35,00 & 0,045 & 0,023 & 0,011 \\
\hline & $* *$ & & & 2,204 & 34,78 & 0,034 & 0,023 & 0,010 \\
\hline \multirow{2}{*}{ dez. 2003} & $*$ & 0,0332 & 0,8566 & 3,228 & 35,00 & 0,003 & 0,028 & 0,009 \\
\hline & $* *$ & & & 3,170 & 28,28 & 0,004 & 0,028 & 0,009 \\
\hline \multirow{2}{*}{ jan. 2004} & $*$ & 0,3172 & 0,5769 & 2,832 & 35,00 & 0,008 & 0,025 & 0,009 \\
\hline & $* *$ & & & 2,872 & 31,63 & 0,007 & 0,025 & 0,009 \\
\hline \multirow{2}{*}{ fev. 2004} & $*$ & 0,4870 & 0,4899 & 2,632 & 35,00 & 0,013 & 0,024 & 0,009 \\
\hline & $* *$ & & & 2,703 & 32,78 & 0,011 & 0,024 & 0,009 \\
\hline \multirow{2}{*}{ mar. 2004} & $*$ & 1,1959 & 0,2816 & 2,249 & 35,00 & 0,031 & 0,023 & 0,010 \\
\hline & $* *$ & & & 2,363 & 34,39 & 0,024 & 0,023 & 0,010 \\
\hline \multirow{2}{*}{ abr. 2004} & $*$ & 1,6707 & 0,2046 & 1,803 & 35,00 & 0,080 & 0,020 & 0,011 \\
\hline & $* *$ & & & 1,939 & 35,00 & 0,061 & 0,020 & 0,010 \\
\hline \multirow{2}{*}{ mai. 2004} & $*$ & 1,3249 & 0,2575 & 1,780 & 35,00 & 0,084 & 0,020 & 0,011 \\
\hline & $* *$ & & & 1,917 & 35,00 & 0,063 & 0,020 & 0,010 \\
\hline \multirow{2}{*}{ jun. 2004} & $*$ & 0,1897 & 0,6658 & 2,311 & 35,00 & 0,027 & 0,021 & 0,009 \\
\hline & $* *$ & & & 2,345 & 31,73 & 0,025 & 0,021 & 0,009 \\
\hline
\end{tabular}


Tabela 16 - Teste da diferença das médias para a variável Provisão. Cont. Tab.15

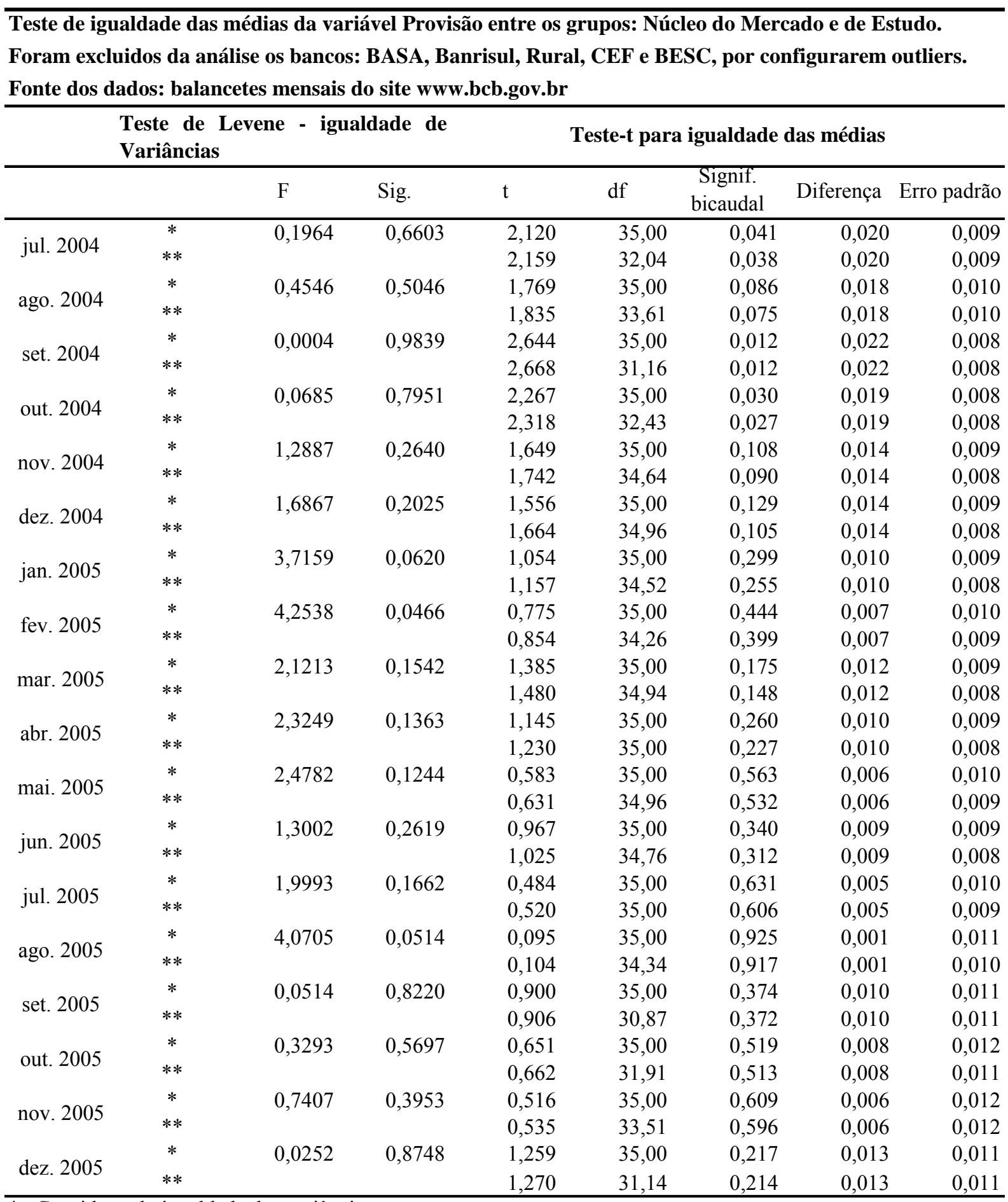

* Considerando igualdade das variâncias

** Considerando variâncias diferentes

O indicador Provisão apresenta um comportamento diverso. De setembro de 2003 a outubro de 2004, a diferença é significativa e positiva, indicando a utilização de um nível de provisão maior por parte das instituições do Grupo Núcleo do Mercado. Essa diferença, ao contrário de indicar um nível de risco maior nas operações de crédito dos bancos que compõem esse grupo, na maior parte bancos grandes, representa uma postura mais 
conservadora desses bancos, o que é freqüentemente mencionado nos balanços. De novembro de 2004 a dezembro de 2005, essa situação se inverte e a diferença deixa de ser significativa, indicando que o nível de provisão é equivalente. Pela observação do comportamento das médias de cada grupo, confirma-se que foram as médias da Provisão do Grupo de Estudo que aumentaram.

Diversos motivos poderiam explicar essa mudança de comportamento. A primeira é que, após a intervenção, houve um aumento do perfil de risco dos bancos que compõem o Grupo de Estudo. Os gráficos 10 e 11 detalham a evolução da participação, relativa e absoluta, de cada nível de risco, no agregado das carteiras de crédito dos bancos que compõem o Grupo de Estudo. Os gráficos foram obtidos a partir dos saldos contábeis das carteiras classificadas de acordo com a Res. $2.682^{5}$.

Gráfico 10 - Evolução da participação por nível de risco da carteira do Grupo de Estudo

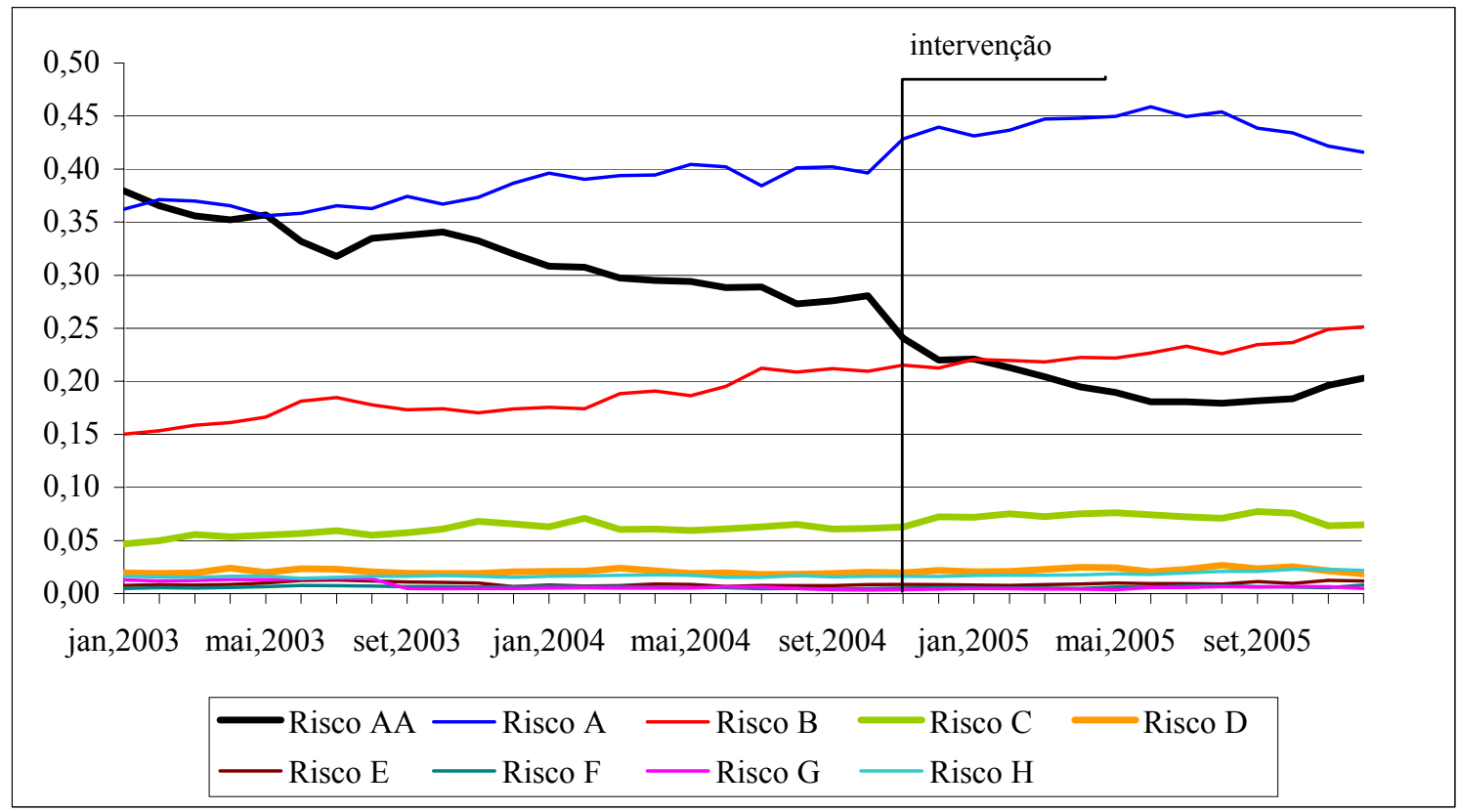

\footnotetext{
${ }^{5}$ A Res. 2.682, do Conselho Monetário Nacional estabeleceu critérios para a classificação das operações de crédito, de acordo com risco. A escala para classificação é alfabética e a cada classe corresponde um nível mínimo de aprovisionamento. O nível com menor risco é o AA, com provisão igual a 0 , e o maior o $\mathrm{H}$, com provisão igual a $100 \%$.
} 
Gráfico 11 - Evolução da carteira de crédito do Grupo de Estudo, por nível de risco

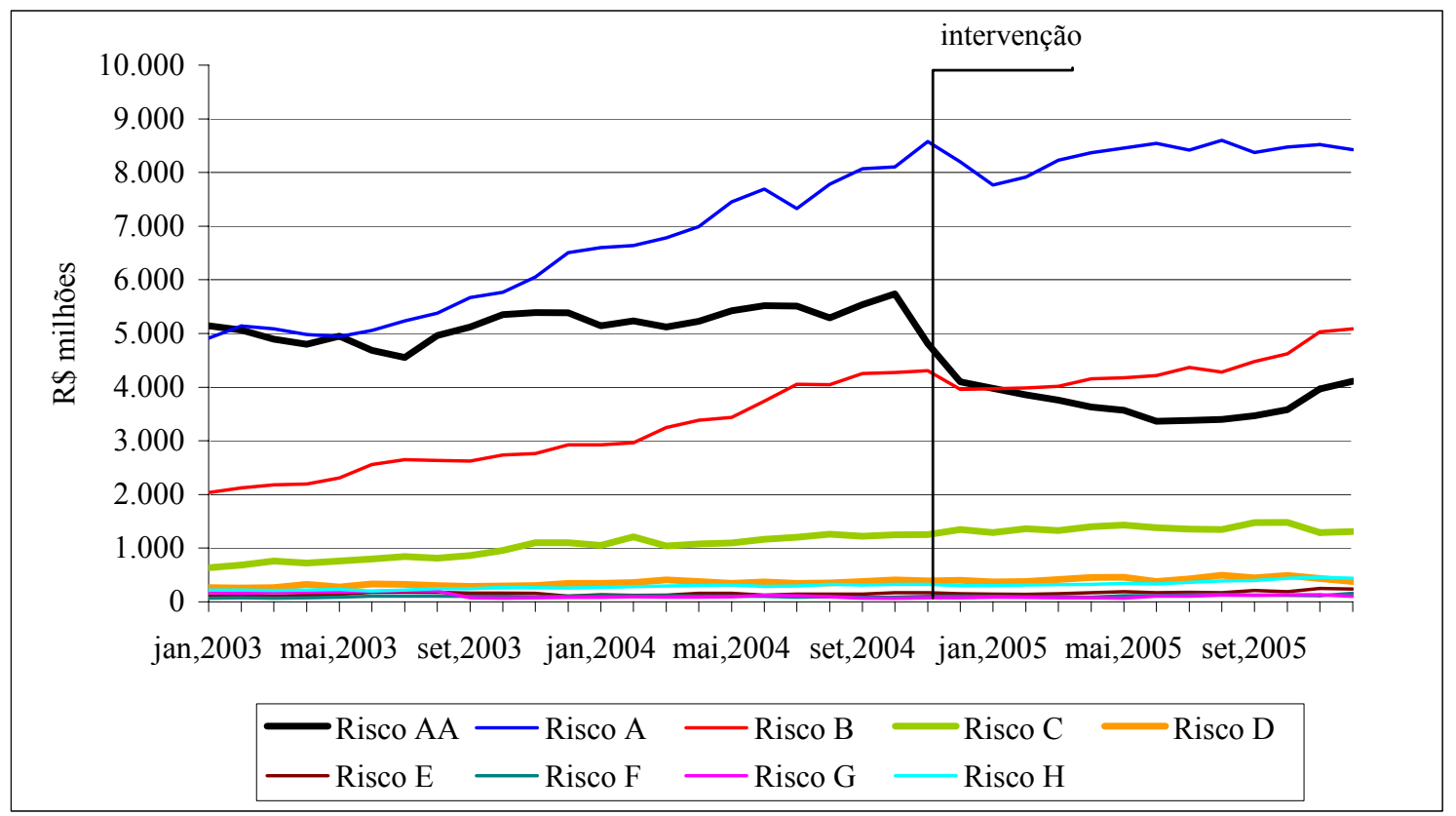

A análise dos gráficos demonstra que, embora a participação relativa dos créditos classificados como AA viesse decaindo, seu montante absoluto vinha se mantendo estável até próximo à intervenção. Esse comportamento se devia ao crescimento dos créditos nos demais níveis de risco, principalmente nos níveis A, B e C. Logo após a intervenção constata-se uma queda brusca nos créditos de nível de risco AA, A e B. Verifica-se também que, em dezembro de 2004, a participação dos créditos de nível de risco AA passa a ser igual a dos créditos de nível de risco B e, daí para diante, a participação do nível de risco B passa a ser maior. Esse comportamento parece indicar que as cessões para os grandes bancos deram-se nos créditos com menor nível de risco, mais compatíveis com as características de risco desses bancos. Uma outra possibilidade é que essa mudança de perfil deva-se a aceitação de um maior risco em busca de um aumento da rentabilidade, tendo em vista a perda de escala na operação motivada pela redução das fontes de financiamento. Os mesmos tipos de gráfico, 12 e 13, para o Grupo Núcleo do Mercado, demonstram a diferença de comportamento. 
Gráfico 12 - Evolução da carteira de crédito por nível de risco - Grupo Núcleo do Mercado

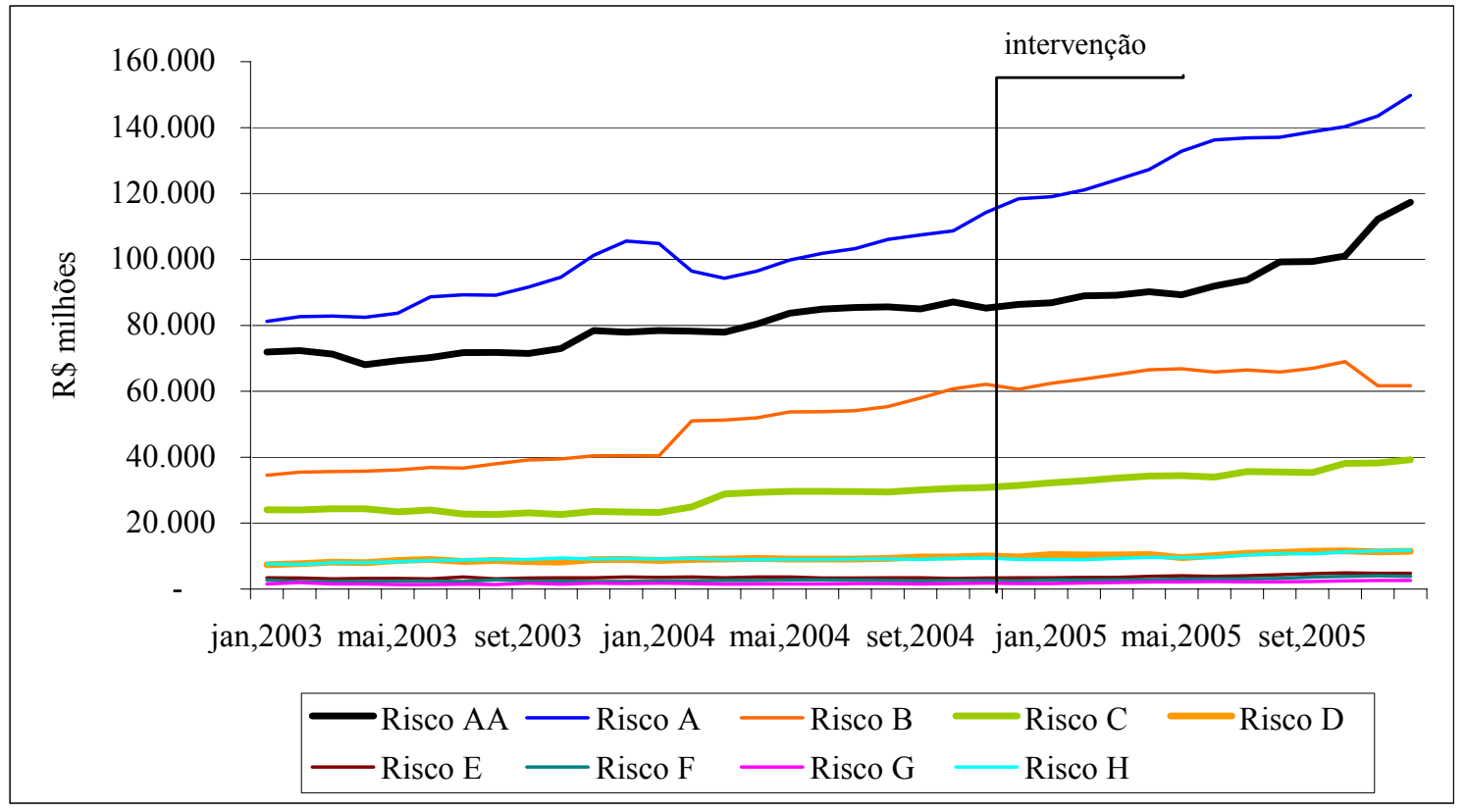

Gráfico 13 - Evolução da participação por nível de risco da carteira do Grupo Núcleo do Mercado

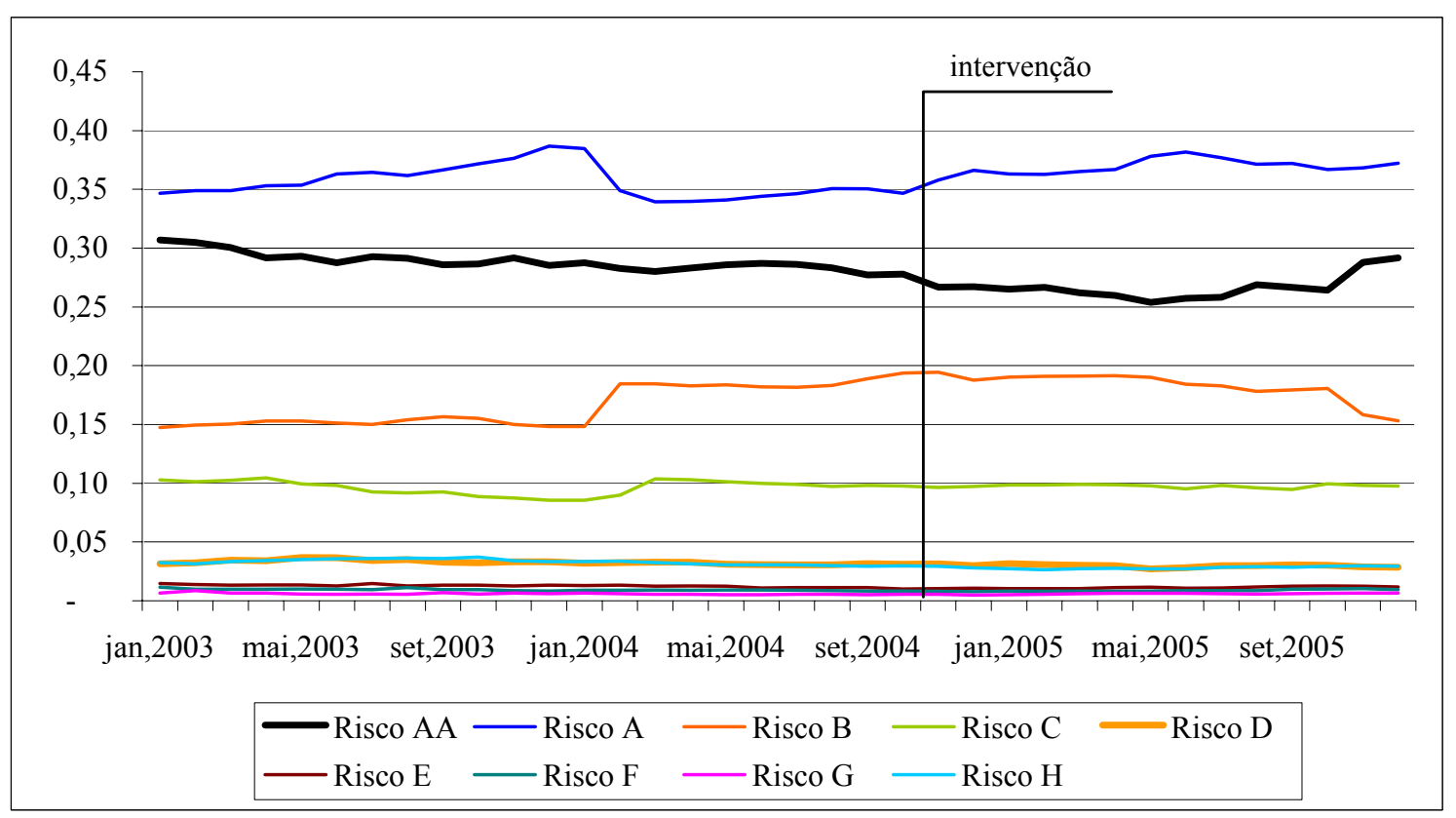

Os gráficos 12 e 13 mostram que o decaimento da participação relativa dos créditos classificados como AA, no grupo Núcleo do Mercado, decorre de um crescimento mais acentuado das carteiras classificadas como A e B, visto que o saldo da carteira classificada como AA cresce ao longo de todo o período. Destaque-se, a ocorrência de um repique na curva dos saldos da carteira classificada como A, justamente em novembro de 2004, que 
poderia ser atribuído à incorporação dos créditos adquiridos dos bancos que passavam por dificuldades de liquidez.

Tabela 17 - Teste da diferença das médias para a variável Jurospassivo

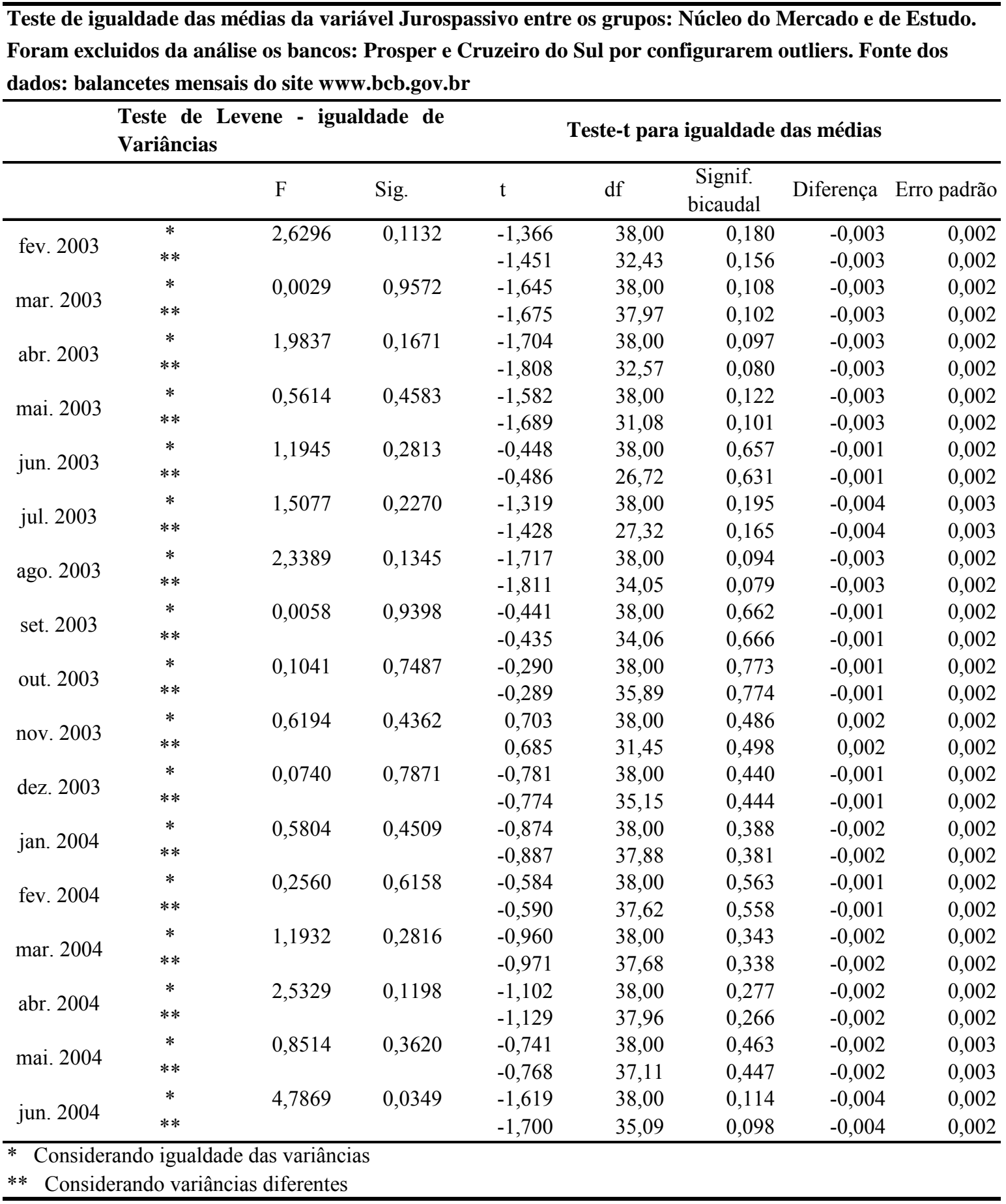


Tabela 18 - Teste da diferença das médias para a variável Jurospassivo. Cont. Tab.17

\begin{tabular}{|c|c|c|c|c|c|c|c|c|}
\hline \multicolumn{9}{|c|}{$\begin{array}{l}\text { Teste de igualdade das médias da variável Jurospas } \\
\text { Foram excluidos da análise os bancos: Prosper e Crt } \\
\text { dados: balancetes mensais do site www.bcb.gov.br }\end{array}$} \\
\hline & \multicolumn{4}{|c|}{$\begin{array}{l}\text { Teste de Levene - igualdade de } \\
\text { Variâncias }\end{array}$} & \multicolumn{4}{|c|}{ [este-t para igualdade das médias } \\
\hline & & $\mathrm{F}$ & Sig. & $\mathrm{t}$ & df & $\begin{array}{l}\text { Signif. } \\
\text { bicaudal }\end{array}$ & Diferença & Erro padrão \\
\hline \multirow{2}{*}{ jul. 2004} & $*$ & 9,7145 & 0,0035 & $-1,959$ & 38,00 & 0,058 & $-0,004$ & 0,002 \\
\hline & ** & & & $-2,092$ & 30,99 & 0,045 & $-0,004$ & 0,002 \\
\hline \multirow{2}{*}{ ago. 2004} & $*$ & 4,5462 & 0,0395 & $-1,285$ & 38,00 & 0,207 & $-0,002$ & 0,002 \\
\hline & $* *$ & & & $-1,345$ & 35,64 & 0,187 & $-0,002$ & 0,002 \\
\hline \multirow{2}{*}{ set. 2004} & * & 5,7245 & 0,0218 & $-1,848$ & 38,00 & 0,072 & $-0,003$ & 0,001 \\
\hline & $* *$ & & & $-1,948$ & 34,30 & 0,060 & $-0,003$ & 0,001 \\
\hline \multirow{2}{*}{ out. 2004} & $*$ & 2,4950 & 0,1225 & $-1,752$ & 38,00 & 0,088 & $-0,002$ & 0,001 \\
\hline & $* *$ & & & $-1,814$ & 37,18 & 0,078 & $-0,002$ & 0,001 \\
\hline \multirow{2}{*}{ nov. 2004} & $*$ & 7,4680 & 0,0095 & $-1,936$ & 38,00 & 0,060 & $-0,003$ & 0,001 \\
\hline & $* *$ & & & $-2,048$ & 33,42 & 0,049 & $-0,003$ & 0,001 \\
\hline \multirow{2}{*}{ dez. 2004} & $*$ & 6,2417 & 0,0169 & $-1,862$ & 38,00 & 0,070 & $-0,004$ & 0,002 \\
\hline & ** & & & $-1,948$ & 35,71 & 0,059 & $-0,004$ & 0,002 \\
\hline \multirow{2}{*}{ jan. 2005} & $*$ & 10,6227 & 0,0024 & $-2,126$ & 38,00 & 0,040 & $-0,005$ & 0,002 \\
\hline & ** & & & $-2,239$ & 34,42 & 0,032 & $-0,005$ & 0,002 \\
\hline \multirow{2}{*}{ fev. 2005} & $*$ & 13,9414 & 0,0006 & $-1,994$ & 38,00 & 0,053 & $-0,005$ & 0,002 \\
\hline & $* *$ & & & $-2,165$ & 26,52 & 0,040 & $-0,005$ & 0,002 \\
\hline \multirow{2}{*}{ mar. 2005} & $*$ & 8,9735 & 0,0048 & $-2,254$ & 38,00 & 0,030 & $-0,008$ & 0,003 \\
\hline & $* *$ & & & $-2,454$ & 25,67 & 0,021 & $-0,008$ & 0,003 \\
\hline \multirow{2}{*}{ abr. 2005} & $*$ & 10,8890 & 0,0021 & $-1,747$ & 38,00 & 0,089 & $-0,004$ & 0,002 \\
\hline & $* *$ & & & $-1,859$ & 31,87 & 0,072 & $-0,004$ & 0,002 \\
\hline \multirow{2}{*}{ mai. 2005} & $*$ & 12,6146 & 0,0010 & $-1,709$ & 38,00 & 0,096 & $-0,003$ & 0,002 \\
\hline & $* *$ & & & $-1,812$ & 32,86 & 0,079 & $-0,003$ & 0,002 \\
\hline \multirow{2}{*}{ jun. 2005} & $*$ & 7,2834 & 0,0103 & $-2,006$ & 38,00 & 0,052 & $-0,004$ & 0,002 \\
\hline & $* *$ & & & $-2,093$ & 36,22 & 0,043 & $-0,004$ & 0,002 \\
\hline \multirow{2}{*}{ jul. 2005} & $*$ & 15,5621 & 0,0003 & $-2,517$ & 38,00 & 0,016 & $-0,006$ & 0,003 \\
\hline & $* *$ & & & $-2,697$ & 30,16 & 0,011 & $-0,006$ & 0,002 \\
\hline \multirow{2}{*}{ ago. 2005} & $*$ & 3,5908 & 0,0657 & $-1,471$ & 38,00 & 0,150 & $-0,007$ & 0,005 \\
\hline & $* *$ & & & $-1,548$ & 34,47 & 0,131 & $-0,007$ & 0,005 \\
\hline \multirow{2}{*}{ set. 2005} & $*$ & 5,2020 & 0,0283 & $-1,251$ & 38,00 & 0,218 & $-0,004$ & 0,003 \\
\hline & $* *$ & & & $-1,325$ & 33,15 & 0,194 & $-0,004$ & 0,003 \\
\hline \multirow{2}{*}{ out. 2005} & $*$ & 5,1383 & 0,0292 & $-1,663$ & 38,00 & 0,105 & $-0,004$ & 0,002 \\
\hline & ** & & & $-1,752$ & 34,30 & 0,089 & $-0,004$ & 0,002 \\
\hline \multirow{2}{*}{ nov. 2005} & $*$ & 5,2461 & 0,0276 & $-1,355$ & 38,00 & 0,183 & $-0,003$ & 0,002 \\
\hline & $* *$ & & & $-1,420$ & 35,35 & 0,164 & $-0,003$ & 0,002 \\
\hline \multirow{2}{*}{ dez. 2005} & $*$ & 7,4587 & 0,0095 & $-2,108$ & 38,00 & 0,042 & $-0,007$ & 0,003 \\
\hline & $* *$ & & & $-2,226$ & 33,80 & 0,033 & $-0,007$ & 0,003 \\
\hline
\end{tabular}

Pretendeu-se avaliar, com o indicador Jurospassivo, o comportamento do custo de captação ao longo de todo o período analisado. Um aumento inesperado dos juros, por parte desses bancos, num período anterior e próximo à data da intervenção, seria um forte indicativo de uma antecipação da situação pelo mercado assim como da ocorrência do efeito contágio. Posteriormente à intervenção, era de se esperar que houvesse um aumento das taxas 
de juros visando manter e atrair novos depositantes. O resultado da análise indica que a partir de julho de 2004 as variâncias entre os dois grupos passam a ser significativamente diferentes. Verifica-se também que, no período de julho de 2004 a julho de 2005, à exceção de agosto de 2004, a média do indicador Jurospassivo para o Grupo de Estudo é significativamente superior à média do Grupo Núcleo do Mercado (diferença das médias é negativa). Esse resultado poderia indicar que efetivamente houve um aumento dos juros praticados por algumas instituições do Grupo de Estudo em data anterior à intervenção e que esse padrão se manteve até julho de 2005. Essa constatação indicaria que os bancos enfrentaram a demanda por liquidez com venda de títulos públicos, resgate e cessão de créditos para bancos maiores e, possivelmente, com o aumento da taxa de juros de captação. Cabe ressaltar que o nível de abertura contábil disponibilizado ao público pelo Banco Central não permite distinguir as despesas concernentes apenas aos depósitos. A abertura existente agrega itens como as despesas com operações compromissadas, que não foram consideradas interessantes para a presente análise. Procurou-se extrair esse efeito subtraindo das despesas de captação o valor: [Saldo de Operações Compromissadas X taxa Selic do Mês], que seria um indicativo das despesas específicas das compromissadas. A simplificação impõe uma maior cautela na análise dos resultados obtidos.

\subsection{Duração da Crise}

Um outro aspecto que merece ser abordado é o tempo de duração da crise. Mais especificamente, a partir de que data as instituições do grupo selecionado deixaram de sofrer drenagem de recursos. Para essa análise definiu-se a variável:

$$
\text { Variação dos Depósitos }{ }_{\mathrm{j}}=\operatorname{Ln}\left(\frac{\text { Saldo da Conta Depósitos mês } \mathrm{i}+1_{\mathrm{j}}}{\text { Saldo da Conta Depósitos mês } \mathrm{i}_{\mathrm{j}}}\right)
$$

que representa a variação mensal, para cada instituição (índice j), do saldo da conta de depósitos.

Essa variável foi submetida a dois testes de média mensal. Na tabela 19, verifica-se o comportamento da média do Grupo de Estudo em relação ao valor zero, para todo o período 
considerado. Nas tabelas 20 e 21, efetuou-se a comparação entre o Grupo de Estudo e o Núcleo de Mercado, visando avaliar se o comportamento dessas médias é, efetivamente, distinto.

Tabela 19 - Teste da média da variação dos depósitos - Grupo de Estudo

\begin{tabular}{|c|c|c|c|c|c|c|}
\hline \multicolumn{7}{|c|}{$\begin{array}{l}\text { Teste para valor da média em relação a } 0 \text { das variações dos depósitos para o } \\
\text { grupo de estudo. Fonte dos dados: balancetes mensais do site }\end{array}$} \\
\hline \multirow[b]{2}{*}{ fev. 2003} & \multirow{2}{*}{$\frac{\mathbf{t}}{2,77}$} & \multirow{2}{*}{ df } & \multirow{2}{*}{$\begin{array}{c}\begin{array}{c}\text { Significância } \\
\text { bicaudal }\end{array} \\
0,011\end{array}$} & \multirow{2}{*}{$\begin{array}{r}\begin{array}{r}\text { Diferença } \\
\text { da média }\end{array} \\
0,032\end{array}$} & \multicolumn{2}{|c|}{$\begin{array}{l}\text { Intervalo de confiança } \\
\text { de } 97,5 \%\end{array}$} \\
\hline & & & & & 0,004 & 0,060 \\
\hline mar. 2003 & 2,97 & 23 & 0,007 & 0,036 & 0,007 & 0,064 \\
\hline abr. 2003 & 1,23 & 23 & 0,230 & 0,042 & $-0,040$ & 0,124 \\
\hline mai. 2003 & 5,17 & 23 & 0,000 & 0,054 & 0,029 & 0,080 \\
\hline jun. 2003 & 1,48 & 23 & 0,152 & 0,021 & $-0,013$ & 0,054 \\
\hline jul. 2003 & 4,06 & 23 & 0,000 & 0,040 & 0,016 & 0,063 \\
\hline ago. 2003 & 3,63 & 23 & 0,001 & 0,041 & 0,014 & 0,068 \\
\hline set. 2003 & 3,35 & 23 & 0,003 & 0,032 & 0,009 & 0,055 \\
\hline out. 2003 & 2,13 & 23 & 0,044 & 0,025 & $-0,003$ & 0,053 \\
\hline nov. 2003 & 1,45 & 23 & 0,162 & 0,015 & $-0,010$ & 0,039 \\
\hline dez. 2003 & 4,37 & 23 & 0,000 & 0,050 & 0,022 & 0,077 \\
\hline jan. 2004 & 2,04 & 23 & 0,053 & 0,018 & $-0,003$ & 0,038 \\
\hline fev. 2004 & 1,77 & 23 & 0,089 & 0,016 & $-0,006$ & 0,037 \\
\hline mar. 2004 & 5,39 & 23 & 0,000 & 0,044 & 0,025 & 0,064 \\
\hline abr. 2004 & 1,94 & 23 & 0,064 & 0,018 & $-0,004$ & 0,039 \\
\hline mai. 2004 & 6,64 & 23 & 0,000 & 0,058 & 0,037 & 0,079 \\
\hline jun. 2004 & 4,17 & 23 & 0,000 & 0,041 & 0,018 & 0,065 \\
\hline jul. 2004 & 3,13 & 23 & 0,005 & 0,024 & 0,006 & 0,042 \\
\hline ago. 2004 & 3,03 & 23 & 0,006 & 0,028 & 0,006 & 0,051 \\
\hline set. 2004 & 1,50 & 23 & 0,148 & 0,017 & $-0,010$ & 0,043 \\
\hline out. 2004 & 0,43 & 23 & 0,670 & 0,006 & $-0,026$ & 0,037 \\
\hline nov. 2004 & $-6,35$ & 23 & 0,000 & $-0,129$ & $-0,178$ & $-0,081$ \\
\hline dez. 2004 & $-5,21$ & 23 & 0,000 & $-0,105$ & $-0,154$ & $-0,057$ \\
\hline jan. 2005 & $-4,07$ & 23 & 0,000 & $-0,057$ & $-0,090$ & $-0,023$ \\
\hline fev. 2005 & $-0,92$ & 23 & 0,367 & $-0,014$ & $-0,051$ & 0,023 \\
\hline mar. 2005 & 1,45 & 23 & 0,160 & 0,014 & $-0,009$ & 0,036 \\
\hline abr. 2005 & 1,53 & 23 & 0,139 & 0,015 & $-0,008$ & 0,038 \\
\hline mai. 2005 & $-0,23$ & 23 & 0,818 & $-0,006$ & $-0,066$ & 0,054 \\
\hline jun. 2005 & 1,85 & 23 & 0,077 & 0,042 & $-0,012$ & 0,097 \\
\hline jul. 2005 & $-1,66$ & 23 & 0,110 & $-0,034$ & $-0,082$ & 0,015 \\
\hline ago. 2005 & $-0,77$ & 23 & 0,450 & $-0,014$ & $-0,059$ & 0,030 \\
\hline set. 2005 & 1,64 & 23 & 0,115 & 0,030 & $-0,014$ & 0,075 \\
\hline out. 2005 & 0,73 & 23 & 0,473 & 0,006 & $-0,013$ & 0,025 \\
\hline nov. 2005 & 2,37 & 23 & 0,027 & 0,020 & 0,000 & 0,041 \\
\hline dez. 2005 & 3,88 & 23 & 0,001 & 0,046 & 0,017 & 0,074 \\
\hline
\end{tabular}

Verifica-se que a variável não apresenta valor significativo negativo para o Grupo de Estudo, para nenhum mês anterior a novembro de 2004; pelo contrário, as variações observadas são, em geral, positivas e significativas. Já, entre novembro de 2004 e janeiro de 2005, a variação é significativamente negativa o que indica um período de duração da crise de 
cerca de três meses. De fevereiro a outubro de 2005, não há significância estatística de que a média seja diferente de zero, configurando um período de nove meses de relativa estagnação. Somente para os meses de novembro e dezembro de 2005, passa a haver um crescimento significativamente diferente de zero.

Deve-se registrar que, como os saldos mensais das Contas de Depósitos refletem não apenas a agregação do fluxo líquido de recursos do período, mas também, a remuneração sobre os recursos existentes, a variável utilizada tem um incremento intrínseco positivo. Apesar desse aparente viés, os resultados do teste da média não parecem ser prejudicados, principalmente pela significância dos valores negativos (que, segundo essa lógica, estariam atenuados). Essa distorção potencial é bastante minimizada ao efetuar-se o comparativo entre as médias do Grupo de Estudo e do Núcleo do Mercado, pois esse efeito da adição da remuneração afetaria os dois grupos. 
Tabela 20 - Teste de igualdade das médias da variação de depósitos

Teste de igualdade das médias das variações dos depósitos entre os grupos: de estudo e núcleo do mercado. Fonte dos dados: balancetes mensais do site www.bcb.gov.br

\begin{tabular}{|c|c|c|c|c|c|c|c|c|}
\hline & \multicolumn{3}{|c|}{$\begin{array}{l}\text { Teste de Levene - } \\
\text { igualdade de Variâncias }\end{array}$} & \multicolumn{5}{|c|}{ Teste-t para igualdade das médias } \\
\hline & & $\mathrm{F}$ & Sig. & $\mathrm{t}$ & df & $\begin{array}{l}\text { Signif. } \\
\text { bicaudal }\end{array}$ & Diferença & $\begin{array}{c}\text { Erro } \\
\text { padrão }\end{array}$ \\
\hline \multirow{2}{*}{ fev. 2003} & $*$ & 2,9742 & 0,0923 & 1,572 & 40,00 & 0,124 & 0,023 & 0,015 \\
\hline & $* *$ & & & 1,714 & 35,70 & 0,095 & 0,023 & 0,014 \\
\hline \multirow{2}{*}{ mar. 2003} & $*$ & 0,5229 & 0,4738 & 1,860 & 40,00 & 0,070 & 0,029 & 0,015 \\
\hline & $* *$ & & & 2,014 & 36,95 & 0,051 & 0,029 & 0,014 \\
\hline \multirow{2}{*}{ abr. 2003} & $*$ & 2,8402 & 0,0997 & 1,337 & 40,00 & 0,189 & 0,054 & 0,040 \\
\hline & $* *$ & & & 1,529 & 25,64 & 0,138 & 0,054 & 0,035 \\
\hline \multirow{2}{*}{ mai. 2003} & $*$ & 1,7237 & 0,1967 & 1,972 & 40,00 & 0,056 & 0,030 & 0,015 \\
\hline & $* *$ & & & 2,028 & 39,59 & 0,049 & 0,030 & 0,015 \\
\hline \multirow{2}{*}{ jun. 2003} & $*$ & 0,7535 & 0,3905 & 0,581 & 40,00 & 0,565 & 0,012 & 0,021 \\
\hline & $* *$ & & & 0,588 & 38,32 & 0,560 & 0,012 & 0,020 \\
\hline \multirow{2}{*}{ jul. 2003} & $*$ & 0,8493 & 0,3623 & 2,304 & 40,00 & 0,026 & 0,032 & 0,014 \\
\hline & $* *$ & & & 2,362 & 39,40 & 0,023 & 0,032 & 0,014 \\
\hline \multirow{2}{*}{ ago. 2003} & $*$ & 4,8607 & 0,0333 & 1,818 & 40,00 & 0,077 & 0,026 & 0,015 \\
\hline & $* *$ & & & 1,961 & 37,49 & 0,057 & 0,026 & 0,013 \\
\hline \multirow{2}{*}{ set. 2003} & $*$ & 5,0842 & 0,0297 & 1,908 & 40,00 & 0,064 & 0,023 & 0,012 \\
\hline & $* *$ & & & 2,085 & 35,41 & 0,044 & 0,023 & 0,011 \\
\hline \multirow{2}{*}{ out. 2003} & $*$ & 2,3174 & 0,1358 & 2,165 & 40,00 & 0,036 & 0,033 & 0,015 \\
\hline & $* *$ & & & 2,317 & 38,55 & 0,026 & 0,033 & 0,014 \\
\hline \multirow{2}{*}{ nov. 2003} & $*$ & 0,7530 & 0,3907 & $-1,948$ & 40,00 & 0,058 & $-0,040$ & 0,021 \\
\hline & $* *$ & & & $-1,817$ & 25,91 & 0,081 & $-0,040$ & 0,022 \\
\hline \multirow{2}{*}{ dez. 2003} & $*$ & 6,4108 & 0,0154 & 2,781 & 40,00 & 0,008 & 0,041 & 0,015 \\
\hline & $* *$ & & & 2,989 & 38,01 & 0,005 & 0,041 & 0,014 \\
\hline \multirow{2}{*}{ jan. 2004} & $*$ & 0,1522 & 0,6985 & 2,097 & 40,00 & 0,042 & 0,029 & 0,014 \\
\hline & $* *$ & & & 2,063 & 34,36 & 0,047 & 0,029 & 0,014 \\
\hline \multirow{2}{*}{ fev. 2004} & $*$ & 1,4118 & 0,2418 & $-0,553$ & 40,00 & 0,584 & $-0,007$ & 0,012 \\
\hline & $* *$ & & & $-0,586$ & 39,38 & 0,561 & $-0,007$ & 0,011 \\
\hline \multirow{2}{*}{ mar. 2004} & $*$ & 0,4756 & 0,4944 & 2,372 & 40,00 & 0,023 & 0,031 & 0,013 \\
\hline & $* *$ & & & 2,355 & 35,74 & 0,024 & 0,031 & 0,013 \\
\hline \multirow{2}{*}{ abr. 2004} & $*$ & 0,1893 & 0,6658 & 0,956 & 40,00 & 0,345 & 0,012 & 0,013 \\
\hline & $* *$ & & & 0,985 & 39,70 & 0,331 & 0,012 & 0,012 \\
\hline \multirow{2}{*}{ mai. 2004} & $*$ & 3,4553 & 0,0704 & 0,970 & 40,00 & 0,338 & 0,011 & 0,012 \\
\hline & $* *$ & & & 1,034 & 38,93 & 0,307 & 0,011 & 0,011 \\
\hline \multirow{2}{*}{ jun. 2004} & $*$ & 6,6417 & 0,0138 & 2,535 & 40,00 & 0,015 & 0,032 & 0,012 \\
\hline & $* *$ & & & 2,773 & 35,19 & 0,009 & 0,032 & 0,011 \\
\hline
\end{tabular}


Tabela 21 - Teste de igualdade das médias da variação de depósitos. Cont. Tab. 20

Teste de igualdade das médias das variações dos depósitos entre os grupos: de estudo e núcleo do mercado. Fonte dos dados: balancetes mensais do site www.bcb.gov.br

\begin{tabular}{|c|c|c|c|c|c|c|c|c|}
\hline & \multicolumn{3}{|c|}{$\begin{array}{l}\text { Teste de Levene - } \\
\text { igualdade de Variâncias }\end{array}$} & \multicolumn{5}{|c|}{ Teste-t para igualdade das médias } \\
\hline & & $\mathrm{F}$ & Sig. & $\mathrm{t}$ & df & $\begin{array}{l}\text { Signif. } \\
\text { bicaudal }\end{array}$ & Diferença & $\begin{array}{c}\text { Erro } \\
\text { padrão }\end{array}$ \\
\hline \multirow{2}{*}{ jul. 2004} & $*$ & 12,9935 & 0,0009 & 1,855 & 40,00 & 0,071 & 0,018 & 0,009 \\
\hline & $* *$ & & & 2,043 & 33,97 & 0,049 & 0,018 & 0,009 \\
\hline \multirow{2}{*}{ ago. 2004} & $*$ & 0,8627 & 0,3586 & 1,187 & 40,00 & 0,242 & 0,015 & 0,013 \\
\hline & $* *$ & & & 1,256 & 39,54 & 0,216 & 0,015 & 0,012 \\
\hline \multirow{2}{*}{ set. 2004} & $*$ & 2,9012 & 0,0963 & 0,778 & 40,00 & 0,441 & 0,011 & 0,014 \\
\hline & $* *$ & & & 0,853 & 34,70 & 0,399 & 0,011 & 0,013 \\
\hline \multirow{2}{*}{ out. 2004} & $*$ & 2,1100 & 0,1541 & $-0,680$ & 40,00 & 0,500 & $-0,012$ & 0,018 \\
\hline & $* *$ & & & $-0,717$ & 39,73 & 0,477 & $-0,012$ & 0,017 \\
\hline \multirow{2}{*}{ nov. 2004} & $*$ & 18,5590 & 0,0001 & $-5,709$ & 40,00 & 0,000 & $-0,142$ & 0,025 \\
\hline & $* *$ & & & $-6,349$ & 31,90 & 0,000 & $-0,142$ & 0,022 \\
\hline \multirow{2}{*}{ dez. 2004} & $*$ & 12,7039 & 0,0010 & $-5,131$ & 40,00 & 0,000 & $-0,125$ & 0,024 \\
\hline & $* *$ & & & $-5,754$ & 30,03 & 0,000 & $-0,125$ & 0,022 \\
\hline \multirow{2}{*}{ jan. 2005} & $*$ & 2,1969 & 0,1461 & $-4,624$ & 40,00 & 0,000 & $-0,082$ & 0,018 \\
\hline & $* *$ & & & $-5,005$ & 37,02 & 0,000 & $-0,082$ & 0,016 \\
\hline \multirow{2}{*}{ fev. 2005} & $*$ & 3,4134 & 0,0721 & $-1,263$ & 40,00 & 0,214 & $-0,024$ & 0,019 \\
\hline & $* *$ & & & $-1,402$ & 32,29 & 0,170 & $-0,024$ & 0,017 \\
\hline \multirow{2}{*}{ mar. 2005} & $*$ & 0,1026 & 0,7504 & $-0,793$ & 40,00 & 0,432 & $-0,012$ & 0,015 \\
\hline & $* *$ & & & $-0,789$ & 35,97 & 0,435 & $-0,012$ & 0,015 \\
\hline \multirow{2}{*}{ abr. 2005} & $*$ & 1,9830 & 0,1668 & 0,545 & 40,00 & 0,589 & 0,008 & 0,014 \\
\hline & $* *$ & & & 0,550 & 37,90 & 0,586 & 0,008 & 0,014 \\
\hline \multirow{2}{*}{ mai. 2005} & $*$ & 3,1549 & 0,0833 & $-0,511$ & 40,00 & 0,612 & $-0,015$ & 0,029 \\
\hline & $* *$ & & & $-0,588$ & 24,26 & 0,562 & $-0,015$ & 0,025 \\
\hline \multirow{2}{*}{ jun. 2005} & $*$ & 4,2118 & 0,0467 & 0,773 & 40,00 & 0,444 & 0,021 & 0,027 \\
\hline & $* *$ & & & 0,878 & 27,26 & 0,388 & 0,021 & 0,024 \\
\hline \multirow{2}{*}{ jul. 2005} & $*$ & 5,3878 & 0,0255 & $-1,819$ & 40,00 & 0,076 & $-0,044$ & 0,024 \\
\hline & $* *$ & & & $-2,069$ & 26,95 & 0,048 & $-0,044$ & 0,021 \\
\hline \multirow{2}{*}{ ago. 2005} & $*$ & 8,0491 & 0,0071 & $-1,473$ & 40,00 & 0,149 & $-0,032$ & 0,022 \\
\hline & $* *$ & & & $-1,686$ & 25,49 & 0,104 & $-0,032$ & 0,019 \\
\hline \multirow{2}{*}{ set. 2005} & $*$ & 6,3437 & 0,0159 & 0,490 & 40,00 & 0,627 & 0,011 & 0,022 \\
\hline & $* *$ & & & 0,550 & 29,72 & 0,586 & 0,011 & 0,020 \\
\hline \multirow{2}{*}{ out. 2005} & $*$ & 1,8031 & 0,1869 & $-0,955$ & 40,00 & 0,345 & $-0,011$ & 0,011 \\
\hline & $* *$ & & & $-0,978$ & 39,32 & 0,334 & $-0,011$ & 0,011 \\
\hline \multirow{2}{*}{ nov. 2005} & $*$ & 1,2360 & 0,2729 & 1,318 & 40,00 & 0,195 & 0,017 & 0,013 \\
\hline & $* *$ & & & 1,327 & 37,62 & 0,193 & 0,017 & 0,013 \\
\hline \multirow{2}{*}{ dez. 2005} & $*$ & 0,0607 & 0,8066 & 1,051 & 40,00 & 0,300 & 0,019 & 0,018 \\
\hline & $* *$ & & & 1,045 & 35,93 & 0,303 & 0,019 & 0,018 \\
\hline
\end{tabular}

As tabelas 20 e 21 confirmam que, até novembro de 2004, a maior parte das diferenças entre as médias de variação mensal não era significativa ou quando era, as médias do Grupo de Estudo eram maiores. De novembro de 2004 a janeiro de 2005, a média do grupo de Estudo passa a ser significativamente inferior à do Núcleo do Mercado, confirmando a 
conclusão anterior de extensão da crise pelo período de três meses. Por outro lado, a análise da média, a partir de fevereiro de 2005, não mostra diferenças significativas entre os dois grupos, indicando que, em vez de estagnação, o comportamento observado representa um padrão geral do próprio mercado.

\subsection{Fatores Determinantes do Contágio - Análise Discriminante.}

O Grupo de Estudo é composto pelas instituições que apresentaram variação negativa no saldo da conta de depósitos no período da intervenção no banco Santos, ou seja, seriam as instituições potencialmente contagiadas. Pela composição do grupo pode se depreender um rol de características similares. Tratam-se, de forma geral, de bancos privados, pequenos e médios, com pequeno número de unidades ou agências, com controle familiar e com atuação em nichos específicos do mercado de crédito. Podem ser apontados como grandes exceções desse grupamento, os bancos Alfa e Basa, que possuem volumes de ativo e patrimônio líquido substancialmente maiores que a média do grupo; sendo que o Basa é instituição pública federal. A opção por incluir esses bancos no grupo de estudo deveu-se unicamente ao perfil de evolução dos depósitos no período da intervenção.

Seria interessante avaliar se existem, e quais seriam, os indicadores contábeis que melhor expressariam esse processo de eleição efetuado pelo mercado. Tal abordagem foi conduzida por meio da técnica de análise discriminante utilizando-se o software estatístico SPSS. Utilizou-se para análise o Grupo de Estudo e o Grupo Núcleo do Mercado, este último representando $86,6 \%$ do total de depósitos do sistema financeiro. O grupo Núcleo do Mercado foi identificado na análise com a categoria 1 e o Grupo de Estudo com a categoria 2. Adotouse um período considerado não contaminado, de fevereiro de 2003 a setembro de 2004, que abrangeu um total de 840 dados para cada indicador utilizado. A exclusão do mês de janeiro de 2003 deve-se única e exclusivamente a uma razão metodológica, pois, para alguns indicadores, optou-se por utilizar a média entre os saldos finais de dois meses consecutivos enquanto para outros, foram utilizados saldos de diferentes contas em um mesmo mês. Os indicadores utilizados na análise foram os seguintes:

Depativo $=\frac{\text { Depósitos }}{\text { Ativo }}$ 
Liquidez $=\frac{\text { Liquidez Total }}{\text { Ativo }}$
Liquidez Depósito $=\frac{\text { Liquidez }}{\text { Depósitos }}$

Depósito Crédito $=\frac{\text { Depósitos }}{\text { Operações de Crédito }}$

Capital $=\frac{\text { Patrimônio Líquido }+ \text { Resultado }}{\text { Ativo }}$

Crédito $\mathrm{Pl}=\frac{\text { Operações de Crédito }}{\text { Patrimônio Líquido }+ \text { Resultado }}$

Jurosativo $=\frac{\text { Rendas de Operações de Crédito }}{\text { Operações de Crédito }}$

Depósito $\mathrm{Pl}=\frac{\text { Saldo de Depósitos }}{\text { Patrimônio Líquido }+ \text { Resultado }}$

ROA $=\frac{\text { Contas de Resultado Credoras }- \text { Contas de Resultado Devedoras }}{\text { Ativo }}$

ROE $=\frac{\text { Contas de Resultado Credoras }- \text { Contas de Resultado Devedoras }}{\text { Patrimônio Líquido }}$

Ativo ponderado $=\frac{\text { Ativo }}{\text { Ativo total }(\text { Grupo de Estudo }+ \text { Núcleo do Mercado })}$

Provisão $=\frac{\text { Provisão sobre Operações de Crédito }}{(\text { Saldo de Oper. de Crédito mês i }+ \text { Saldo de Oper. de Crédito mês i }+1)}$

Patrimonioponderado $=\frac{\text { Patrimônio }}{\text { Patrimônio total }(\text { Grupo de Estudo }+ \text { Núcleo do Mercado })}$

Juros passivo $=\frac{\text { Despesas de Captação }- \text { Obrigações Compromis. } \mathrm{x} \text { Taxa Selic }}{\text { Depósitos }+ \text { Recursos Ac. Cambiais, Letras Imobil., Debêntures e similares }}$ 
onde Liquidez Total, corresponde ao conceito definido no subtítulo 3.6.

De forma a avaliar a robustez do resultado da inferência estatística foi definido sorteio aleatório de cerca de $70 \%$ dos 840 dados disponíveis, correspondendo a 576 dados que foram utilizados para definir a função discriminante. Posteriormente, os dados remanescentes, um total de 264, foram utilizados para testar a função discriminante obtida. Os coeficientes e variáveis significativas encontradas estão relacionados na tabela 22 , as estatísticas mais importantes referentes à robustez da função discriminante constam da tabela 23 e os resultados da classificação obtidos utilizando-se a função discriminante, na tabela 24.

Tabela 22 - Coeficientes da função discriminante

\begin{tabular}{lrr}
\hline \multicolumn{3}{c}{ Coeficientes da função discriminante } \\
\hline Indicadores & Padronizados & Não Padronizados \\
\hline Provisao de Crédito & 0,309 & 7,412 \\
Ativo ponderado & 0,630 & 14,104 \\
Liquidez & 0,573 & 3,957 \\
Constante & & $-2,096$ \\
\hline
\end{tabular}

Tabela 23 - Sumário das estatísticas da função discriminante canônica

\begin{tabular}{|c|c|c|c|}
\hline Eigenvalue & \% daVariância & Cumulative \% & Correlação Canonica \\
\hline 0,7490 & 100 & 100 & 0,6544 \\
\hline Lambda de Wilks & Chi-square & df & Sig. \\
\hline 0,5718 & 328,9936 & 3 & $5,26973 \mathrm{E}-71$ \\
\hline
\end{tabular}

Tabela 24 - Resultados da análise discriminante

\begin{tabular}{|c|c|c|c|c|c|c|}
\hline \multicolumn{7}{|c|}{$\begin{array}{l}\text { Resultados da Classificação utilizando a função discriminante (a,b). O grupo } 1 \text { representa o } \\
\text { grupo Núcleo do Mercado e o } 2 \text { o grupo de Estudo }\end{array}$} \\
\hline & & & Grupo & Prev & & Total \\
\hline & & & & 1 & 2 & \\
\hline \multirow{4}{*}{ Casos Selecionados } & \multirow{4}{*}{ Original } & \multirow{2}{*}{ Contagem } & 1 & 205 & 53 & 258 \\
\hline & & & 2 & 25 & 309 & 334 \\
\hline & & \multirow{2}{*}{$\%$} & 1 & 79,46 & 20,54 & 100 \\
\hline & & & 2 & 7,49 & 92,51 & 100 \\
\hline \multirow{4}{*}{ Casos Não Selecionados } & \multirow{4}{*}{ Original } & \multirow{2}{*}{ Contagem } & 1 & 73,00 & 29,00 & 102 \\
\hline & & & 2 & 7,00 & 139,00 & 146 \\
\hline & & \multirow{2}{*}{$\%$} & 1 & 71,57 & 28,43 & 100 \\
\hline & & & 2 & 4,79 & 95,21 & 100 \\
\hline
\end{tabular}

Os resultados da classificação com a função discriminante, tabela 24, foram bastante satisfatórios, $87 \%$ no global, para os casos selecionados para obtenção da função discriminante e $85,5 \%$ para o grupo de controle. O potencial de acerto, classificação correta, é 
bem maior para o Grupo 2 (Grupo de Estudo). Esse resultado era esperado, pois se trata de um grupo bem mais homogêneo, já que no grupo denominado Núcleo do Mercado, além de grandes bancos, foram incluídos alguns de menor porte. Essa heterogeneidade do grupo Núcleo do Mercado, que resultou da metodologia utilizada, análise gráfica e correlação, representa um maior desafio à obtenção da função discriminante e oferece um maior poder para o teste dos resultados obtidos.

Após diversas combinações de variáveis, utilizando as rotinas de otimização do software SPSS e uma avaliação crítica sobre os resultados obtidos, chegou-se à função com maior poder discriminante, composta por apenas três indicadores, tabela 22:

- Ativo ponderado: era um indicador que já se antevia como importante, pois os bancos que de alguma forma foram afetados são pequenos e médios. O coeficiente padronizado obtido foi 0,644 ;

-Liquidez: apresentou um poder discriminante importante, com coeficiente padronizado de 0,601. Talvez seja o mais relevante, pois permite a discriminação entre instituições de mesmo porte.

- Provisão de Crédito: sem dúvida, o indicador mais surpreendente da análise. $\mathrm{O}$ coeficiente padronizado de 0,309 indica que maiores provisões produzem um maior valor da função discriminante contribuindo para a classificação no grupo 1, ou seja, Grupo Núcleo do Mercado. O resultado aparenta ser contraditório, pois implica que a uma maior provisão estaria associada uma menor probabilidade da instituição ser contaminada. Conforme já comentado, essa contradição é apenas aparente. Os grandes bancos brasileiros, freqüentemente, reportam em suas notas explicativas critérios mais conservadores ou mesmo a constituição de provisões adicionais para o risco de crédito. A própria comparação entre os saldos informados nas contas de provisões de créditos dos balancetes e as provisões obtidas multiplicando os saldos de operações em cada nível de risco pelos percentuais estipulados na Resolução 2.682, confirmam essa política. Nesse sentido, uma maior provisão, ao contrário de indicar um maior risco, representaria um maior conservadorismo.

Por outro lado, no item 3.6.2, verificou-se que, após o evento da intervenção no Banco Santos, o valor médio do indicador Provisão para os bancos do Grupo de Estudo sofreu elevação passando a equiparar-se ao dos bancos que compõem o Grupo Núcleo do Mercado. Se por um lado, essa ocorrência elimina o potencial discriminador dessa variável; por outro, a reversão de tendência constitui um elemento significativo associado à crise de liquidez. A ocorrência poderia indicar uma mudança no perfil e composição de risco das carteiras dos bancos do Grupo de Estudo, alteração nos critérios de classificação buscando demonstrar uma 
postura mais conservadora, ou, pelo menos, equivalente à dos grandes bancos, o que seria um importante sinalizador para restabelecer a confiança perante o mercado. 


\section{CONCLUSÕES}

\subsection{Papel do Regulador/Supervisor}

Schoenmaker (1996, p. 1) considera que a necessidade da regulação e supervisão bancária depende, essencialmente, da existência ou não do risco de contágio no sistema bancário.

Essa observação parece resumir o fundamento do surgimento dos bancos centrais como entes de supervisão bancária e sua missão precípua. Embora, com o decorrer do tempo e a depender das características de cada país, diversas outras funções tenham sido incorporadas ao supervisor/regulador. Com base na literatura científica podemos apontar quatro funções ou objetivos que consideramos essenciais para justificar a existência da supervisão bancária:

- Evitar ou minimizar o risco sistêmico que deriva do efeito contágio;

- Evitar o risco moral associado à existência do seguro-depósito, qual seja: a existência do seguro enfraquece o exercício da disciplina de mercado pelo investidor e possibilita a adoção de estratégias de maior risco pelos gestores dos bancos. A supervisão, atuaria como guardiã dessa reserva que, na maior parte dos casos, é de natureza pública;

- Preservar a poupança popular. Nesse caso a supervisão atenuaria a assimetria de informações entre pequenos e grandes poupadores;

- Prevenção à lavagem do dinheiro. É uma atividade cuja execução, em muitos países, vem sendo atribuída à supervisão bancária.

Se avaliarmos a falência do Banco Santos verificaremos que, embora o banco tivesse um volume de ativos respeitável, o volume de créditos habilitados na falência atingiu cerca de $\mathrm{R} \$ 2,7$ bilhões, aparentemente, não houve impacto sistêmico relevante que se propagasse para o setor econômico, o que caracterizaria o banco como sistemicamente não importante. Da mesma forma, o impacto no seguro-depósito (FGC) foi limitado, cerca de R \$15 milhões e parece bastante reduzido tendo em vista o montante do passivo. A própria característica do banco, e desse nicho de mercado, explicam a indenização não ter atingido um valor extremamente elevado. Não se tratava de um banco de varejo, ou seja, tinha uma baixa capacidade de captar poupança popular. Além disso, dado o reduzido limite indenizável de $\mathrm{R} \$ 20$ mil, nos parece que o intento de proteger a poupança popular foi atingido. 
Surge, portanto, num contexto estritamente teórico, uma contradição entre os pressupostos considerados essenciais para a necessidade de supervisão e as reais características dessa instituição, ou mesmo das congêneres: são instituições sistemicamente não importantes, possuem baixo impacto de prejuízo ao seguro-depósito e não têm por objetivo precípuo a captação da poupança popular. A contradição parece, no âmbito teórico, indicar que a supervisão para essas instituições é desnecessária ou poderia ser atenuada e os principais esforços direcionados aos bancos sistemicamente importantes, ou então, poderia se pensar em outro arranjo jurídico para esse tipo de instituição.

Essa última possibilidade, em particular, tem aspectos interessantes se analisada sob a ótica dessas instituições. Embora a submissão à regulação e à supervisão seja extremamente onerosa, principalmente por fatores como: necessidade de capital mínimo, necessidade de atendimento aos limites de Basiléia, adequação e cumprimento das normas, envio e publicação de informações, etc., ela apresenta um aspecto positivo essencial para a vida dessas instituições. A submissão à supervisão referenda a instituição para o mercado e assegura aos investidores que a instituição está sendo devidamente monitorada.

De fato, as características do grupo que sofreu o contágio se aproximam bastante daquelas preconizadas para a proposta relativa aos bancos de crédito num sistema de narrow banking, abordados no capítulo 2.3.1. Seriam bancos que não captariam depósitos à vista, não estariam sujeitos à supervisão e não contariam com a proteção do seguro-depósito. $\mathrm{Na}$ verdade, a partir de 2005, vem ganhando força no mercado brasileiro uma estrutura financeira alternativa que guarda bastante semelhança com o arranjo dos bancos de crédito. São os Fundos de Direitos Creditórios. Tratam-se de estruturas jurídicas que não estão sujeitas à supervisão bancária, portanto, são menos oneradas, não contam com mecanismos de proteção e, até o momento, são destinadas apenas a agentes qualificados do mercado (grandes investidores).

Resta saber se esse tipo de fundo, que por ser menos onerado tem um potencial para oferecer uma rentabilidade maior, atingir melhores características de liquidez, e a própria previsão de reduzirem-se os limites de aplicação, desaguará no seu florescimento ou se haverá uma pressão para submeter esses fundos a uma supervisão mais estrita. 
Sempre existe algum tipo de assimetria de informações entre tomadores e doadores de recursos, além de algum problema de agência quando os detentores de recursos delegam as decisões de investimento para gestores profissionais. Essa relação sempre possibilitará o surgimento de cascatas de informação e de comportamento de manada. A divulgação de informações, a disponibilização periódica de dados e a existência de sistemas de compensação financeira para os gestores mais adequados podem tornar os mercados e instituições mais transparentes. Ainda mais, o desenvolvimento de mercados futuros pode colaborar para trazer informações a respeito das expectativas de mercado para o domínio público.

Muito embora o aumento da profundidade da informação, bem como a adoção de mecanismos mais abrangentes de divulgação, contribuam para reduzir a assimetria não se imagina, de forma nenhuma, eliminá-la por completo. Nesse sentido, aspectos culturais do país e as especificidades do mercado financeiro acabam restringindo o exercício da disciplina a agentes mais qualificados. Esse arranjo, que parece ter caráter injusto e discricionário, acaba sendo ajustado pela existência do seguro-depósito. Quem não tem qualificação para exercer a disciplina de mercado conta com o seguro e quem tem a qualificação tem um incentivo para fazê-lo. È claro que a obtenção de uma solução eqüitativa para esse arranjo não se trata de tarefa trivial. Sempre haverá uma classe de investidores que não contará com uma proteção patrimonial adequada e não disporá de recursos ou qualificação para exercer a disciplina de mercado. O tamanho desse grupo dependerá, fundamentalmente do limite de cobertura estipulado.

A divulgação de ações de fiscalização, nos Estados Unidos, a determinação de que as instituições publiquem avaliações de uma ou duas agências classificadoras de risco independentes, na Argentina, e a gestão do seguro depósito pelo próprio setor bancário, com a prerrogativa de suprimir a cobertura de bancos que tenham comportamento de alto risco ou mesmo sugerir ações de fiscalização, na Alemanha, constituem alguns mecanismos específicos que contribuem para o exercício da disciplina de mercado.

De fato, em relação às avaliações de risco, observou-se que diversos bancos que sofreram resgates acentuados no episódio do Banco Santos, passaram a enfatizar a contratação e divulgação dessas avaliações de forma periódica, além de outras práticas de maior transparência na relação com o mercado.

Um outro fator, pouco comentado, que consideramos importante para a disciplina de mercado, é a presença e imagem do supervisor/regulador bancário. De maneira geral, a 
mera existência de um ente supervisor é um elemento de relaxamento do exercício da disciplina de mercado, pois ocorre a delegação de atribuição. A depender do histórico das crises ocorridas e da extensão das perdas, a confiança atribuída ao supervisor poderá ser exacerbada ou atenuada. Uma maior transparência da supervisão - transmitindo ao mercado de forma clara, qual o papel do supervisor, quais os tipos de ações de fiscalização conduzidas, quais as ferramentas de extensão da análise, ou até uma síntese dos totais e tipos de trabalhos realizados a cada ano - poderia delimitar de forma mais clara para o mercado as reais potencialidades e limitações do trabalho de supervisão.

\subsection{Depósitos Compulsórios}

Os depósitos compulsórios são freqüentemente apontados como mecanismos geradores de ineficiência no mercado financeiro acarretando um nível de taxas de juros acima do desejado. Em particular, as exigências de depósitos compulsórios sobre recursos a prazo e depósitos de poupança são considerados por muitos agentes de mercado de baixa eficácia para efeito da execução da política monetária e deveriam ser simplesmente eliminados. É fato que, mais recentemente, a condução da política monetária brasileira vem privilegiando a utilização da taxa básica de juros, restando aos compulsórios um papel subsidiário de ferramenta estratégica a ser utilizada em momentos de instabilidade financeira.

A crise de liquidez analisada permitiu realçar, de forma enfática, a importância desses depósitos compulsórios como instrumentos garantidores de um nível de liquidez mínimo para as instituições financeiras. A virulência do contágio e a elevada demanda por liquidez que se seguiu em relação ao segmento bancário analisado, não poderia ter sido atendida se esses bancos não dispusessem de um colchão mínimo de liquidez. Eventualmente, se a decisão sobre o nível de liquidez ideal a ser mantido fosse delegado ao mercado, algumas instituições ver-se-iam em severas dificuldades para atender os saques.

Pode-se considerar que a existência dessa reserva exerceu no período da turbulência um triplo papel. Auxiliou no atendimento da primeira onda de saques; sinalizou ao mercado que essas instituições possuíam uma reserva de liquidez e, nesse aspecto, a mera mudança de rubrica contábil de títulos vinculados ao Banco Central para títulos é uma sinalização positiva; e, por fim, assegurou aos bancos o tempo necessário para recuperar ou ceder parte de suas carteiras de crédito. 


\subsection{Empréstimo de Liquidez}

A função de emprestador de última instância, em algumas circunstâncias, pode ser justificada com o fito exclusivo de prevenir o contágio associado às insolvências bancárias. Contudo, o banco central deve prover liquidez e preservar da insolvência bancos que tenham potencial efetivo para produzir um impacto sistêmico (SCHOENMAKER, 1996, p. 86).

O sistema financeiro brasileiro é dominado por um conjunto de bancos grandes, cuja atuação vem crescentemente se diversificando, seja pelo desenvolvimento de novos negócios, seja pela aquisição de instituições menores e mais especializadas. Para essas instituições, a possibilidade de um problema financeiro localizado propagar-se e derivar em uma crise sistêmica é extremamente elevada. Essa situação gera um mecanismo implícito de proteção, cuja ocorrência é fartamente documentada na bibliografia sobre crises financeiras sob a denominação: bancos grandes demais para falir (too big to fail).

No mercado brasileiro, verifica-se que, ao redor das grandes instituições gravitam diversos bancos menores que atuam em segmentos delimitados do mercado, têm atuação restrita no varejo, mesmo porque não contam com um grande número de agências e assim não têm um importante componente de captação de poupança popular.

A crise de liquidez aqui analisada pode ser considerada importante, pois não só ocorreu a falência de uma instituição de médio porte como também houve o espraiamento dessa crise para diversas outras instituições. Verificou-se, contudo, que mesmo com toda a virulência do contágio ocorrido, não se produziu um efeito deletério suficiente para dar início a uma crise sistêmica.

Esse conjunto de características do sistema financeiro brasileiro associado à análise da crise de liquidez ocorrida permite o surgimento de um corolário ao conceito dos bancos grandes demais para falir que passaremos a denominar: bancos pequenos demais para serem salvos (too small to be saved). Isso não quer dizer que as dificuldades desses bancos não são devidamente recepcionadas pelos órgãos supervisores. Significa apenas que esses bancos não têm porte ou potencial deletério suficiente para ensejar tratamento excepcional, geralmente materializado com o aporte de recursos públicos. 
A combinação do seguro-depósito e de mecanismos de intervenção nas falências bancárias é fator primordial da rede de segurança financeira e uma estruturação adequada dos dois pode conduzir a uma minimização das probabilidades e custos de fragilidades financeiras. Adicionalmente, uma regulação e supervisão efetiva, bem como o exercício da disciplina de mercado por grandes depositantes e credores, são fatores que colaboram para delimitar o risco assumido pelas instituições bancárias (BECK, 2003, p. 2).

Pode-se considerar que o seguro-depósito hoje existente no Brasil, limitado a R \$20 mil por depositante, adquiriu a função de proteger o pequeno aplicador, uma vez que seu potencial para evitar a erupção de uma crise sistêmica ou corrida bancária é extremamente reduzido. A existência desse limite dá uma condição peculiar a esse seguro, pois a importância segurada não guarda relação com o prêmio estabelecido. Considerando, por exemplo, a atual alíquota do Fundo Garantidor de Créditos, de 0,3\% a.a. aplicada a depósitos de $\mathrm{R} \$ 2$ milhões, $\mathrm{R} \$ 200$ mil e de $\mathrm{R} \$ 20$ mil, o prêmio anual seria, respectivamente, de $\mathrm{R} \$ 6.000, \mathrm{R} \$ 600$ e R\$60, para o mesmo valor indenizável de $\mathrm{R} \$ 20$ mil.

\subsection{Surpresa do Mercado e Razões do Contágio}

A redução dos preços das ações, devido à publicação de alertas de lucro, é significativamente maior no setor não bancário do que no bancário. Essa distinção de comportamento decorre do fato de o setor bancário ser fortemente regulado o que implicaria num monitoramento do supervisor bancário, seja para adotar medidas corretiva, seja para preservar o nível de capital, o que funcionaria como um limitador de risco de deterioração. (SLOVIN et. al., 1999, p. 223).

A conclusão acima corrobora essa particularidade do sistema financeiro. Por existir uma supervisão específica e, a depender da confiança que o mercado aufere a ela, o mercado passar a delegar-lhe a atividade de monitoramento, afrouxa seus mecanismos próprios de vigia e superestima o potencial de predição de problemas por essa supervisão, principalmente, quando ocorrem eventos de fraude. Ante a surpresa do fato concreto da intervenção, o mercado se surpreende, exacerba suas opiniões e passa a nivelar por baixo, demandando resgate de todas as instituições que tenham características semelhantes à instituição 
insolvente. Entre os fatores apontados por Bikhchandani e Sharma (2001, p. 280), dois fatores poderiam explicar esse comportamento: para administradores de recursos, a imitação é uma forma de preservação, pois a tolerância ao erro individual e localizado é muito menor do que ao erro coletivo ou então seria uma busca intrínseca dos indivíduos por conformidade.

Outro aspecto a ser considerado é que, conforme as notícias mencionadas no histórico de eventos, Apêndice IV, a partir da semana seguinte à intervenção começam a surgir notícias da possibilidade da crise contaminar o sistema. Por outro lado, a rapidez na liberação dos depósitos compulsórios, apenas sete dias após a intervenção, ou teve caráter preventivo, ou demonstra que a propagação do contágio foi extremamente rápida.

Nesse período de contágio, surge uma situação que denominaremos de dilema do supervisor bancário. O supervisor sabe que determinadas instituições, provavelmente todas, não apresentam risco iminente de insolvência. Contudo, por mais saudável que seja uma instituição bancária, nenhuma resiste a uma corrida de resgates prolongada. Por outro lado, acabou de ocorrer uma falência bancária e o supervisor não sabe até que ponto sua credibilidade foi afetada pelo evento. Se ele comunica ao mercado que as demais instituições estão saudáveis e a corrida prossegue, ele corre o risco de ser apontado como responsável pelas perdas dos depositantes que permaneceram. Se ele não comunica ao mercado o número de falências pode ser maior que o necessário. O dilema se torna mais complicado se pelo menos uma das instituições afetadas pela corrida sofrer rápida deterioração e correr risco de insolvência. Nesse caso, o supervisor não pode nem informar que as instituições estão saudáveis, nem que existe pelo menos uma que está enfrentando problemas, o que agravaria ainda mais a crise. Como as cascatas de informação são sensíveis à divulgação de informação pública, esse dilema prejudica fortemente a possibilidade de essas informações, de melhor qualidade, se tornarem públicas.

\subsection{Análise de Indicadores Contábeis}

Os testes estatísticos da média aplicados à variável variação dos depósitos permitiram estabelecer um período de três meses, de novembro de 2004 a janeiro de 2005, como o período ao longo do qual o conjunto de bancos analisados sofreu drenagem de recursos. 
O teste de igualdade das médias para a variável Jurosativo, entre o Grupo de Estudo e o Grupo Núcleo do Mercado não mostrou diferenças significativas. Por outro lado, o aumento da variância do Grupo de Estudo, a partir de dezembro de 2004, pode ser atribuído ao aumento do indicador Jurosativo para algumas instituições, sugerindo uma elevação das taxas das operações de crédito por parte dessas instituições.

Para o indicador Provisão, de setembro de 2003 a outubro de 2004, a diferença é significativa e positiva, indica a utilização de um nível de provisão maior pelas instituições do Grupo Núcleo do Mercado. A razão para isso é que os bancos que compõem esse grupo, na maior parte bancos grandes, adota critérios mais conservadores para o aprovisionamento. De novembro de 2004 a dezembro de 2005, a média de provisão do Grupo de Estudo aumenta e a diferença deixa de ser significativa. O motivo mais provável para esse comportamento seria o aumento do perfil de risco dos bancos que compõem o Grupo de Estudo em virtude da cessão de carteiras de menor risco para outros bancos.

O indicador Jurospassivo demonstra que, a partir de julho de 2004, as variâncias entre os dois grupos passaram a ser significativamente diferentes. Constatou-se também que, no período de julho de 2004 a julho de 2005, à exceção de agosto de 2004, a média do indicador Jurospassivo para o Grupo de Núcleo do Mercado é significativamente inferior à média do Grupo de Estudo (as diferença das médias é negativa ao longo de todo o período). Esse possível aumento dos juros praticados, já em julho de 2004, poderia indicar a resposta de alguns bancos a movimentos de retirada de agentes econômicos que tivessem algum tipo de informação sobre a existência de problemas no mercado financeiro. A mesma lógica se aplicaria após a intervenção. Contudo, a análise da variação dos saldos das contas Depósitos não demonstra a concretização de movimentos marcantes de resgate de recursos.

Utilizou-se, por fim, a técnica de análise discriminante para verificar quais indicadores contábeis melhor reproduziriam a diferenciação pelo mercado entre instituições contagiadas e não contagiadas. Conclui-se, de forma esperada, que o ativo ponderado e a liquidez representaram importantes fatores para essa discriminação. O terceiro indicador, Provisão de Crédito, que a bibliografia apontava como importante para os estudos de falência, apresentou comportamento antagônico. Como o coeficiente desse indicador na função discriminante é positivo, quanto maior o valor da provisão, maior seria a discriminação do banco para o grupo dos não contagiados. Essa aparente contradição decorre de um maior conservadorismo dos bancos grandes nos critérios de aprovisionamento. A partir de novembro de 2004, as diferenças de provisão de crédito entre os dois grupos deixaram de ser significativas o que eliminaria o poder discriminante desse indicador. Portanto, o indicador 
Provisão de Crédito demonstra, pelo menos para o período da análise, baixa confiabilidade para fins de se avaliar a deterioração da situação financeira de uma instituição ou mesmo o perfil de risco de sua carteira de crédito.

\subsection{Aprofundamento da análise}

A análise do contágio, bem como a definição exata das instituições efetivamente afetadas, seria substancialmente enriquecida se pudessem ser utilizados dados de mercado tais como as taxas de juros diárias de captação efetivamente praticadas e os resgates líquidos diários dos depósitos das instituições analisadas.

Outra informação de especial interesse seria o perfil dos depositantes e sacadores das instituições afetadas. Essa informação permitiria identificar movimentos de grupos homogêneos de clientes, por exemplo clientes institucionais, e delinear com maior clareza o desenvolvimento e motivos do contágio. A realização de pesquisa com esses grupos de clientes permitiria averiguar as razões determinantes para a decisão de resgatar os recursos e, assim, caracterizar de forma mais precisa a evolução do fenômeno.

Contudo, a obtenção dessas informações junto aos potenciais provedores (Banco Central do Brasil, FEBRABAN, ABBC, Andima, etc.) não constitui tarefa trivial em virtude de questões relativas ao sigilo dessas informações. No entanto, verifica-se a possibilidade do uso de dados do Banco Central Brasil em condições controladas, como por exemplo, na condição de que os resultados sejam apresentados na forma de média e desvio padrão amostral sem a identificação de cada instituição individualmente (GABRIEL, 2004, p.71).

Esse tipo de tratamento da informação pode representar o caminho para o aprofundamento da análise e uma melhor elucidação do efeito contágio. 


\section{REFERÊNCIAS:}

AHARONY, Joseph; SWARY, Itzhak. Contagion Effects of Bank Failures: Evidence from capital markets. The Journal of Business. Chicago, v. 56, n. 3 p.305-322, 07/1983.

BAGEHOT, Walter. Lombard Street: A Description of the money market. London: John Murray, 1935.

BALARIN, Raquel; VIEIRA, Catherine. Turbulência - Cessão de crédito, FDIC e mercado externo forma alternativa à redução de CDB. Valor Econômico, 10/08/2005. Disponível em $<$ http:http://www.andima.com.br/clipping/100805/100805_03a.html >. Acesso em:19/07/2006

BANCO CENTRAL DO BRASIL. Manual de Supervisão Bancária. ref. 3.70.10.20. Disponível em <http: www.bcb.gov.br>. Acesso em 07/11/2005.

BANCO CENTRAL DO BRASIL. Circular 3.262 e Circular 3.091. Disponível em $<$ http: www.bcb.gov.br>. Acesso em 07/11/2005.

BANCO CENTRAL DO BRASIL. Res. 2.682. Disponível em <http:www.bcb.gov.br>. Acesso em 07/7/2006.

BANCO CENTRAL DO BRASIL. Relatório de Estabilidade Financeira, vol. 3, n. 2, nov. 2004, Disponível em <http:http: www.bcb.gov.br>. Acesso em 02/5/2006.

BECK, Thorsten. The Incentive Compatible Design of Deposit Insurance and Bank Failure Resolution-Concepts and Country Studies. World Bank Policy Research Working Paper 3043, 05/2003. Disponível em <http:www-wds.worldbank.org>. Acesso em 02/02/2006.

BERGER, Allen N.; DAVIES, Sally M.; Flannery, Mark J. Comparing Market and Supervisory Assessments Of Bank Performance: Who Knows what when? Journal of Money, Credit and Banking n.32, ago. 2000 p. 641-667

BIKHCHANDANI, Sushil; SHARMA, Sunil. Herd Behavior in Financial Markets. International Monetary Fund Staff Paper, v. 47, n. 3, 2001.

BONABEAU, Eric. Agent-Based Modeling: Methods and Techniques for Simulating Human Systems. Arthur M. Sacler Colloquium of The National Academy of Sciences, jun. 2002. Disponível em <http:www.pnas.org/cgi/10.1073/pnas.082080899. Acesso em 04/8/2004.

BROOK, Phil; CUNHA, Paulo Vieira da Cunha. The Trouble with Insurance - or, Do High Real Interest Cause Bank Crises?. DEC NOTES, Research findings. World Bank, n. 33, October 1997.

CARVAlHO, Maria Cristina. Cessões da Carteira Preocupam a Fitch. Valor online, 12/07/2006. Disponível em <http://www.valoreconomico.com.br/valoreconomico/285/

financas/54/Cessoes + de + carteira + preocupam $+a+$ Fitch,,,54,3774643.html $>$. Acesso em 17/07/2006. 
CHARI, V.V.; JAGANNATHAN, Ravi. Banking Panics, Information, and Rational Expectations Equilibrium. The Journal of Finance, v. XLIII, n. 3, p. 749-761, 07/1988.

COOPERMAN, Elizabeth S. et. al.. The 1985 Ohio Thrift Crisis, the FSLIC's Solvency, and Rate Contagion for Retail CD. The Journal of Finance, v. XLVII, n. 3, p. 919-941, 07/1992.

DEMINGUÇ-KUNT, Asli; DETRAGIACHE, Enrica. Does Deposit Insurance Increase Banking System Stability? An Empirical Investigation. World Bank Policy Research Working Paper 2247, 08/2000. Disponível em $<\mathrm{http} / / / \mathrm{www}-$ wds.worldbank.org/external/default/WDSContentServer/IW3P/IB/2000/01/06/000094946_99 122006330270/Rendered/PDF/multi_page.pdf>. Acesso em 02/02/2006.

DIAMOND, Douglas W.; DYBVIG, Philip H. Bank Runs, Deposit Insurance, and Liquidity. The Journal of Political Economy, Chicago, v. 91, n. 31 p. 401-419, 1983.

DIAMOND, Douglas W.; RAJAN, G. Raghuram G. Bank Bailouts and Aggregate Liquidity. AEA Papers and Proceedings, Chicago, v. 92, n. 2, p. 38-41, 2002.

. Liquidity Shortages and Banking Crises. NBER Working Paper Series wp. 10071, Cambridge, oct., 2003. Disponível em <http:www.nber.org/papers/w10071>. Acesso em $02 / 02 / 2006$

Fama construída com cifrões e arte, Jornal Zero Hora. Porto Alegre, 16/11/2004.

FERNANDEZ, Roque; SCHUMACHER, Liliana. Does Argentina Provide a Case for Narrow Banking. In: Preventing Banking Sector Distress and Crises in Latin America, 1516/04/1996, World Bank Discussion Paper n. 360, Washington D.C.

GABRIEL, Fernando; O Impacto do Fim da Correção Monetária na Rentabilidade e Adequação de Capital dos Bancos no Brasil . Dissertação (Mestrado em Ciências Contábeis) - Faculdade de Economia, Administração e Contabilidade, Universidade de São Paulo, 2004.

GANCIA, Bárbara. El “Cid” já não é mais "el campeador”. Folha de São Paulo. São Paulo, $19 / 11 / 2004$.

GARRIDO, João. Tendências. Site Valor online, 11/06/2006, Disponível em $<$ http://www.valoronline.com.br/especiais/valorfinanceiro/TENDENCIASBANCARIA.aspx $>$ . Acesso em 12/07/2006

GORTON, Gary; HUANG, Lixin. Liquidity, Efficiency and Bank Bailouts. NBER Working Paper Series wp. 10071, Cambridge, ago. 2002a. Disponível em $<$ http:www.nber.org/papers/w10071>. Acesso em 02/02/2006.

Banking Panics and the Origins of Central Banking. NBER Working Paper Series wp. 9137, Cambridge, set. 2002b. Disponível em <http:www.nber.org/papers/w9137 >. Acesso em 02/02/2006.

GUPTA, Poonam; DEMIRGUÇ-KURT, Aslt; DETRAGIACHE, Enrica. Inside de Crisis: an Empirical Analysis of Banking Systems in Distress. World Bank Policy Research Working 
Paper 2431, 08/2000. Disponível em <http:www-wds.worldbank.org>. Acesso em 02/02/2006.

ISHIHARA, Yoichiro. Quantitative Analysis of Crisis: Crisis Identification and Casualty, World Bank Policy Research Working Paper 3598, 05/2005. Disponível em $<$ http:www-wds.worldbank.org>. Acesso em 02/02/2006.

JACKSON, Dave; MADURA, Jelf. Bank Profit Warnings and Signaling. Managerial Finance, ABI/INFORM GLOBAL, 2004.

LANG, Larry H.P.; STULZ, René M. Contagion and Competitive Intra-Industry effects of Bankruptcy announcements. Journal of Financial Economics, North-Holland, n. 32, p. 45-60, 1992.

LUCCHESI, Cristiane Perini. Bancos pequenos e médios paralisam concessão de crédito. Jornal Valor Econômico. São Paulo, 19/11/2004.

MATARAZZO, Dante G. Análise Financeira de Balanços: Abordagem básica e gerencial, 6. ed. São Paulo: Atlas, 2003.

MORRIS, Stephen; ALLEN, Franklin. Finance Applications of Game Theory, set. 1998 Disponível em $<$ http://cowles.econ.yale.edu/P/cd/d11b/d1195.pdf $>$. Acesso em 15/03/2006.

NASSIF, Luís. O Banqueiro “Mecenas”. Folha de São Paulo. São Paulo, 18/11/2004.

NICHOLL, Peter. Market-Based Banking Regulation. In: Preventing Banking Sector Distress And Crises In Latin America, 15-16/04/1996, World Bank Discussion Paper n. 360, Washington D.C., 03/97

OLIVEIRA, Caio Marcelo Mendes. Falência do Banco Santos S/A. São Paulo: $2^{\text {a }}$ Vara de Falências e Recuperações, 26/10/2005. Disponível em http://www.bancosantos.com.br/intervenção/editalconvocacaodecredores.pdf $>$. Acesso em: $10 / 11 / 2005$.

PEAVY III, John W.; HEMPEL, George H. The Penn Square Bank Failure: Effect on Commercial Bank Security Returns - A Note. Journal of Banking and Finance, p. 141-150, 1988.

POSTLEWAITE, Andrew; VIVES, Xavier. Bank Runs as an Equilibrium Phenomenon. Journal of Political Economy, Chicago, v. 95, n. 31, 1987.

RABERTO, Marco et. al. Agent-based Simulation of a Financial Market. Physica A, 288, p. 319-327, 2001.

SJAASTAD, Larry A. Deposit Insurance: Do We Really Need it. In: Preventing Banking Sector Distress and Crises in Latin America, 15-16/04/1996, World Bank Discussion Paper n. 360 , Washington D.C., 03/97

SAUNDERS, Anthony. Administração de instituições financeiras. São Paulo: Atlas, 2000. 
SCHMUKLER Sergio L. et al. Market Discipline under Systemic Risk: Evidence from Bank Runs in Emerging Economies. World Bank Policy Research Working Paper 3043, 05/2005. . Disponível em $<$ http:www-wds.worldbank.org $>$. Acesso em 02/02/2006.

SCHOENMAKER, Dirk. Contagious Risk in Banking. The Second Joint Central Bank Research Conference On Risk Measurement And Systemic Risk, 03/1996, Disponível em $<$ http:www.imes.boj.org.jp/english/cbrc.html>. Acesso em 02/5/2006.

SLOVIN, Myron B. et. al. Informational Externalities of Seasoned Equity Issues: Differences between banks and industrial firms. Journal of Financial Economics, North Holland, n. 32, p. 87-101, 1992.

WALL, Larry D.; PETERSON, David R. The Effect of Continental Illinois's failure on the financial performance of other banks. Journal of Monetary Economics, North-Holland, n. 26, p. 77-99, 1990.

WELCH, Ivo et al. A Theory of Fads, Fashion, Custom, and Cultural Change as Information Cascades. Journal of Political Economy, Chicago, v. 100, n. 51, p. 992-1026, 1992.

WORLD BANK, Preventing Banking Sector Distress and Crises in Latin America: World Bank Discussion Paper n. 360, 03/97, Disponível em <http:www-wds.worldbank.org> Acesso em 02/02/2006.

YORULMAZER, Tanju. Essays on Bank Runs, Contagion and Systemic Risk. New York, 2003. Tese (Doutorado em Economia) - Departamento de Economia da New York University. 
APENDICE I

Tabela 1 - Correlações entre depósitos dos bancos e total da amostra

Correlações entre os saldos das contas depósitos dos bancos individuais e o saldo do total da amostra utilizada. Fonte:www.bcb.gov.br - balancetes contábeis

\begin{tabular}{|c|c|c|c|}
\hline \multirow[t]{2}{*}{ Instituição } & \multicolumn{3}{|c|}{ Periodo } \\
\hline & jan.03/set. 04 & out.04/mar.05 & out.04/set.05 \\
\hline \multirow[t]{2}{*}{ AbcBrasil } & $-0,674$ & $-0,623$ & 0,501 \\
\hline & 0,001 & 0,186 & 0,097 \\
\hline \multirow[t]{2}{*}{$\overline{\mathrm{ABN}}$} & 0,903 & 0,933 & 0,937 \\
\hline & 0,000 & 0,007 & 0,000 \\
\hline \multirow[t]{2}{*}{ AJRenner } & 0,920 & 0,634 & 0,919 \\
\hline & 0,000 & 0,177 & 0,000 \\
\hline \multirow[t]{2}{*}{ Alfa } & 0,924 & 0,595 & 0,915 \\
\hline & 0,000 & 0,212 & 0,000 \\
\hline \multirow[t]{2}{*}{ AMEX } & $-0,441$ & $-0,641$ & $-0,175$ \\
\hline & 0,045 & 0,170 & 0,587 \\
\hline \multirow[t]{2}{*}{ Arbi } & 0,811 & 0,432 & $-0,320$ \\
\hline & 0,000 & 0,393 & 0,310 \\
\hline \multirow[t]{2}{*}{ Banestes } & 0,974 & 0,862 & 0,896 \\
\hline & 0,000 & 0,027 & 0,000 \\
\hline \multirow{2}{*}{ Banif } & 0,936 & $-0,555$ & 0,781 \\
\hline & 0,000 & 0,253 & 0,003 \\
\hline \multirow[t]{2}{*}{ BankBoston } & 0,048 & 0,329 & 0,073 \\
\hline & 0,838 & 0,524 & 0,822 \\
\hline \multirow[t]{2}{*}{ Banrisul } & 0,644 & 0,918 & 0,968 \\
\hline & 0,002 & 0,010 & 0,000 \\
\hline \multirow{2}{*}{$\overline{\mathrm{BASA}}$} & 0,096 & $-0,480$ & 0,479 \\
\hline & 0,678 & 0,336 & 0,115 \\
\hline \multirow[t]{2}{*}{$\mathrm{BB}$} & 0,958 & 0,949 & 0,895 \\
\hline & 0,000 & 0,004 & 0,000 \\
\hline \multirow[t]{2}{*}{$\overline{\mathrm{BBM}}$} & 0,959 & $-0,849$ & 0,534 \\
\hline & 0,000 & 0,033 & 0,074 \\
\hline \multirow[t]{2}{*}{$\overline{\mathrm{BEC}}$} & 0,945 & 0,776 & 0,862 \\
\hline & 0,000 & 0,069 & 0,000 \\
\hline \multirow[t]{2}{*}{ BES } & 0,962 & 0,858 & 0,833 \\
\hline & 0,000 & 0,029 & 0,001 \\
\hline \multirow[t]{2}{*}{$\overline{\mathrm{BESC}}$} & 0,899 & 0,891 & 0,924 \\
\hline & 0,000 & 0,017 & 0,000 \\
\hline \multirow[t]{2}{*}{ BGN } & 0,952 & 0,728 & 0,625 \\
\hline & 0,000 & 0,101 & 0,030 \\
\hline \multirow[t]{2}{*}{$\mathrm{BIC}$} & 0,946 & $-0,813$ & $-0,354$ \\
\hline & 0,000 & 0,049 & 0,259 \\
\hline \multirow[t]{2}{*}{$\overline{\mathrm{BMC}}$} & 0,891 & $-0,911$ & $-0,801$ \\
\hline & 0,000 & 0,012 & 0,002 \\
\hline \multirow[t]{2}{*}{ BMG } & 0,987 & $-0,835$ & $-0,814$ \\
\hline & 0,000 & 0,039 & 0,001 \\
\hline \multirow[t]{2}{*}{ BNB } & $-0,608$ & 0,876 & 0,648 \\
\hline & 0,003 & 0,022 & 0,023 \\
\hline $\begin{array}{ll}(*) & \text { Coefi } \\
(* *) & \text { Sign }\end{array}$ & $\begin{array}{l}\text { lção de } \\
\text { dal) }\end{array}$ & & \\
\hline
\end{tabular}


Tabela 2 - Correlações entre depósitos dos bancos e total da amostra

Correlações entre os saldos das contas depósitos dos bancos individuais e o saldo do total da amostra utilizada. Fonte:www.bcb.gov.br - balancetes contábeis

\begin{tabular}{|c|c|c|c|}
\hline \multirow[t]{2}{*}{ Instituição } & \multicolumn{3}{|c|}{ Periodo } \\
\hline & jan.03/set. 04 & out.04/mar.05 & out.04/set.05 \\
\hline \multirow[t]{2}{*}{ Gerdau } & 0,849 & $-0,831$ & $-0,956$ \\
\hline & 0,000 & 0,040 & 0,000 \\
\hline \multirow[t]{2}{*}{$\overline{\text { GMAC }}$} & 0,690 & 0,540 & 0,387 \\
\hline & 0,001 & 0,269 & 0,214 \\
\hline \multirow[t]{2}{*}{ Guanabara } & 0,372 & 0,493 & 0,901 \\
\hline & 0,096 & 0,320 & 0,000 \\
\hline \multirow[t]{2}{*}{ Honda } & 0,985 & 0,960 & 0,986 \\
\hline & 0,000 & 0,002 & 0,000 \\
\hline \multirow[t]{2}{*}{$\overline{\mathrm{HSBC}}$} & 0,980 & 0,989 & 0,991 \\
\hline & 0,000 & 0,000 & 0,000 \\
\hline \multirow[t]{2}{*}{ Ibi } & 0,867 & 0,773 & 0,916 \\
\hline & 0,000 & 0,072 & 0,000 \\
\hline \multirow[t]{2}{*}{ IndustrialdoBrasil } & 0,928 & $-0,929$ & $-0,759$ \\
\hline & 0,000 & 0,007 & 0,004 \\
\hline \multirow[t]{2}{*}{ Indusval } & 0,877 & $-0,473$ & 0,392 \\
\hline & 0,000 & 0,343 & 0,208 \\
\hline \multirow[t]{2}{*}{$\mathrm{ING}$} & 0,208 & 0,722 & 0,882 \\
\hline & 0,365 & 0,105 & 0,000 \\
\hline \multirow[t]{2}{*}{ Intercap } & 0,506 & 0,677 & $-0,564$ \\
\hline & 0,019 & 0,140 & 0,056 \\
\hline \multirow[t]{2}{*}{$\overline{\text { ITAU }}$} & $-0,141$ & 0,884 & 0,920 \\
\hline & 0,542 & 0,019 & 0,000 \\
\hline \multirow[t]{2}{*}{ JMalucelli } & 0,975 & $-0,875$ & 0,408 \\
\hline & 0,000 & 0,022 & 0,188 \\
\hline \multirow[t]{2}{*}{ JPMorgan } & 0,842 & $-0,293$ & 0,082 \\
\hline & 0,000 & 0,573 & 0,800 \\
\hline \multirow{2}{*}{ LusoBrasileiro } & 0,972 & $-0,853$ & $-0,563$ \\
\hline & 0,000 & 0,031 & 0,057 \\
\hline \multirow[t]{2}{*}{ Matone } & 0,574 & 0,271 & 0,461 \\
\hline & 0,007 & 0,604 & 0,131 \\
\hline \multirow[t]{2}{*}{ MercantildoBrasil } & 0,969 & $-0,915$ & $-0,772$ \\
\hline & 0,000 & 0,010 & 0,003 \\
\hline \multirow[t]{2}{*}{$\overline{\text { Modal }}$} & 0,932 & $-0,969$ & $-0,896$ \\
\hline & 0,000 & 0,001 & 0,000 \\
\hline \multirow[t]{2}{*}{ Morada } & 0,825 & 0,727 & $-0,382$ \\
\hline & 0,000 & 0,101 & 0,220 \\
\hline \multirow[t]{2}{*}{ NossaCaixa } & 0,967 & 0,742 & 0,838 \\
\hline & 0,000 & 0,091 & 0,001 \\
\hline \multirow[t]{2}{*}{ Pactual } & 0,190 & 0,366 & 0,147 \\
\hline & 0,408 & 0,476 & 0,649 \\
\hline \multirow[t]{2}{*}{ Pecunia } & 0,957 & $-0,987$ & $-0,950$ \\
\hline & 0,000 & 0,000 & 0,000 \\
\hline
\end{tabular}


Tabela 3 - Correlações entre depósitos dos bancos e total da amostra

Correlações entre os saldos da contas depósitos dos bancos individuais e o saldo do total da amostra utilizada. Fonte:www.bcb.gov.br - balancetes contábeis

\begin{tabular}{|c|c|c|c|}
\hline \multirow[t]{2}{*}{ Instituição } & \multicolumn{3}{|c|}{ Periodo } \\
\hline & jan.03/set. 04 & out.04/mar.05 & out.04/set.05 \\
\hline \multirow[t]{2}{*}{ Bonsucesso } & 0,946 & $-0,771$ & 0,594 \\
\hline & 0,000 & 0,072 & 0,042 \\
\hline \multirow[t]{2}{*}{ Bradesco } & 0,918 & 0,924 & 0,705 \\
\hline & 0,000 & 0,008 & 0,010 \\
\hline \multirow[t]{2}{*}{ Brascan } & $-0,921$ & $-0,839$ & $-0,093$ \\
\hline & 0,000 & 0,037 & 0,774 \\
\hline \multirow[t]{2}{*}{$\overline{\mathrm{BRB}}$} & 0,957 & 0,763 & 0,922 \\
\hline & 0,000 & 0,077 & 0,000 \\
\hline \multirow[t]{2}{*}{ Cacique } & 0,913 & 0,624 & 0,735 \\
\hline & 0,000 & 0,186 & 0,006 \\
\hline \multirow[t]{2}{*}{ Cedula } & 0,798 & 0,863 & 0,947 \\
\hline & 0,000 & 0,027 & 0,000 \\
\hline \multirow[t]{2}{*}{$\overline{\mathrm{CEF}}$} & 0,978 & 0,986 & 0,993 \\
\hline & 0,000 & 0,000 & 0,000 \\
\hline \multirow[t]{2}{*}{ Citibank } & 0,854 & 0,898 & 0,588 \\
\hline & 0,000 & 0,015 & 0,044 \\
\hline \multirow[t]{2}{*}{ CooperativoBrasil } & $-0,206$ & 0,943 & 0,199 \\
\hline & 0,370 & 0,005 & 0,535 \\
\hline \multirow[t]{2}{*}{ CooperativoSicredi } & $-0,205$ & $-0,815$ & 0,385 \\
\hline & 0,372 & 0,048 & 0,217 \\
\hline \multirow[t]{2}{*}{ Credibel } & 0,201 & $-0,632$ & 0,388 \\
\hline & 0,383 & 0,178 & 0,212 \\
\hline \multirow[t]{2}{*}{ CreditSuisse } & 0,729 & $-0,047$ & 0,049 \\
\hline & 0,000 & 0,929 & 0,880 \\
\hline \multirow[t]{2}{*}{ CruzeirodoSul } & 0,983 & $-0,799$ & $-0,543$ \\
\hline & 0,000 & 0,057 & 0,068 \\
\hline \multirow[t]{2}{*}{ DaimlerChrysler } & 0,848 & 0,862 & 0,890 \\
\hline & 0,000 & 0,027 & 0,000 \\
\hline \multirow[t]{2}{*}{ Daycoval } & 0,969 & $-0,738$ & 0,498 \\
\hline & 0,000 & 0,094 & 0,100 \\
\hline \multirow[t]{2}{*}{ Deutsche } & 0,797 & $-0,571$ & $-0,678$ \\
\hline & 0,000 & 0,236 & 0,015 \\
\hline \multirow[t]{2}{*}{ Dresdner } & $-0,618$ & 0,874 & 0,955 \\
\hline & 0,003 & 0,023 & 0,000 \\
\hline \multirow[t]{2}{*}{ Emblema } & 0,185 & 0,768 & 0,303 \\
\hline & 0,422 & 0,075 & 0,338 \\
\hline \multirow[t]{2}{*}{ Fibra } & 0,748 & $-0,129$ & 0,416 \\
\hline & 0,000 & 0,808 & 0,178 \\
\hline \multirow[t]{2}{*}{$\overline{\text { Ficsa }}$} & 0,843 & $-0,780$ & $-0,771$ \\
\hline & 0,000 & 0,067 & 0,003 \\
\hline \multirow[t]{2}{*}{ Ford } & 0,632 & $-0,371$ & 0,791 \\
\hline & 0,002 & 0,469 & 0,002 \\
\hline
\end{tabular}


Tabela 4 - Correlações entre depósitos dos bancos e total da amostra

Correlações entre os saldos das contas depósitos dos bancos individuais e o saldo do total da amostra utilizada. Fonte:www.bcb.gov.br - balancetes contábeis

\begin{tabular}{|c|c|c|c|}
\hline \multirow[t]{2}{*}{ Instituição } & \multicolumn{3}{|c|}{ Periodo } \\
\hline & jan.03/set. 04 & out.04/mar.05 & out.04/set.05 \\
\hline \multirow[t]{2}{*}{ Pine } & 0,979 & $-0,810$ & $-0,588$ \\
\hline & 0,000 & 0,051 & 0,044 \\
\hline \multirow[t]{2}{*}{ Prosper } & 0,732 & $-0,750$ & 0,178 \\
\hline & 0,000 & 0,086 & 0,580 \\
\hline \multirow[t]{2}{*}{ PSAFinance } & 0,971 & 0,150 & 0,857 \\
\hline & 0,000 & 0,777 & 0,000 \\
\hline \multirow[t]{2}{*}{ Rabobank } & 0,648 & 0,850 & 0,780 \\
\hline & 0,001 & 0,032 & 0,003 \\
\hline \multirow[t]{2}{*}{ Rendimento } & 0,934 & 0,428 & 0,649 \\
\hline & 0,000 & 0,397 & 0,022 \\
\hline \multirow[t]{2}{*}{ Rural } & 0,978 & $-0,917$ & $-0,962$ \\
\hline & 0,000 & 0,010 & 0,000 \\
\hline \multirow[t]{2}{*}{ Safra } & 0,605 & 0,669 & 0,822 \\
\hline & 0,004 & 0,146 & 0,001 \\
\hline \multirow[t]{2}{*}{ SantanderBanespa } & 0,352 & 0,896 & 0,959 \\
\hline & 0,117 & 0,016 & 0,000 \\
\hline \multirow[t]{2}{*}{ Santos } & 0,889 & $-0,040$ & $-0,682$ \\
\hline & 0,000 & 0,940 & 0,030 \\
\hline \multirow[t]{2}{*}{ Schahin } & 0,975 & $-0,825$ & $-0,684$ \\
\hline & 0,000 & 0,043 & 0,014 \\
\hline \multirow[t]{2}{*}{ SocieteGeneral } & $-0,323$ & 0,827 & 0,369 \\
\hline & 0,154 & 0,042 & 0,238 \\
\hline \multirow[t]{2}{*}{ Socopa } & 0,979 & 0,377 & 0,860 \\
\hline & 0,000 & 0,461 & 0,000 \\
\hline \multirow[t]{2}{*}{ Sofisa } & 0,906 & $-0,781$ & 0,612 \\
\hline & 0,000 & 0,067 & 0,035 \\
\hline \multirow[t]{2}{*}{ SS } & 0,963 & $-0,886$ & $-0,779$ \\
\hline & 0,000 & 0,019 & 0,003 \\
\hline \multirow[t]{2}{*}{ TokioMitsubishi } & 0,854 & $-0,020$ & $-0,645$ \\
\hline & 0,000 & 0,971 & 0,024 \\
\hline \multirow[t]{2}{*}{ Toyota } & 0,881 & 0,968 & 0,972 \\
\hline & 0,000 & 0,001 & 0,000 \\
\hline \multirow[t]{2}{*}{ Triangulo } & 0,975 & 0,115 & $-0,651$ \\
\hline & 0,000 & 0,829 & 0,022 \\
\hline \multirow[t]{2}{*}{ Tricury } & 0,755 & 0,698 & 0,877 \\
\hline & 0,000 & 0,123 & 0,000 \\
\hline \multirow[t]{2}{*}{ Unibanco } & 0,924 & 0,979 & 0,854 \\
\hline & 0,000 & 0,001 & 0,000 \\
\hline \multirow[t]{2}{*}{ Volkswagen } & 0,399 & 0,805 & 0,905 \\
\hline & 0,074 & 0,053 & 0,000 \\
\hline \multirow[t]{2}{*}{ Votorantim } & 0,961 & 0,669 & 0,922 \\
\hline & 0,000 & 0,146 & 0,000 \\
\hline
\end{tabular}


APÊNDICE II
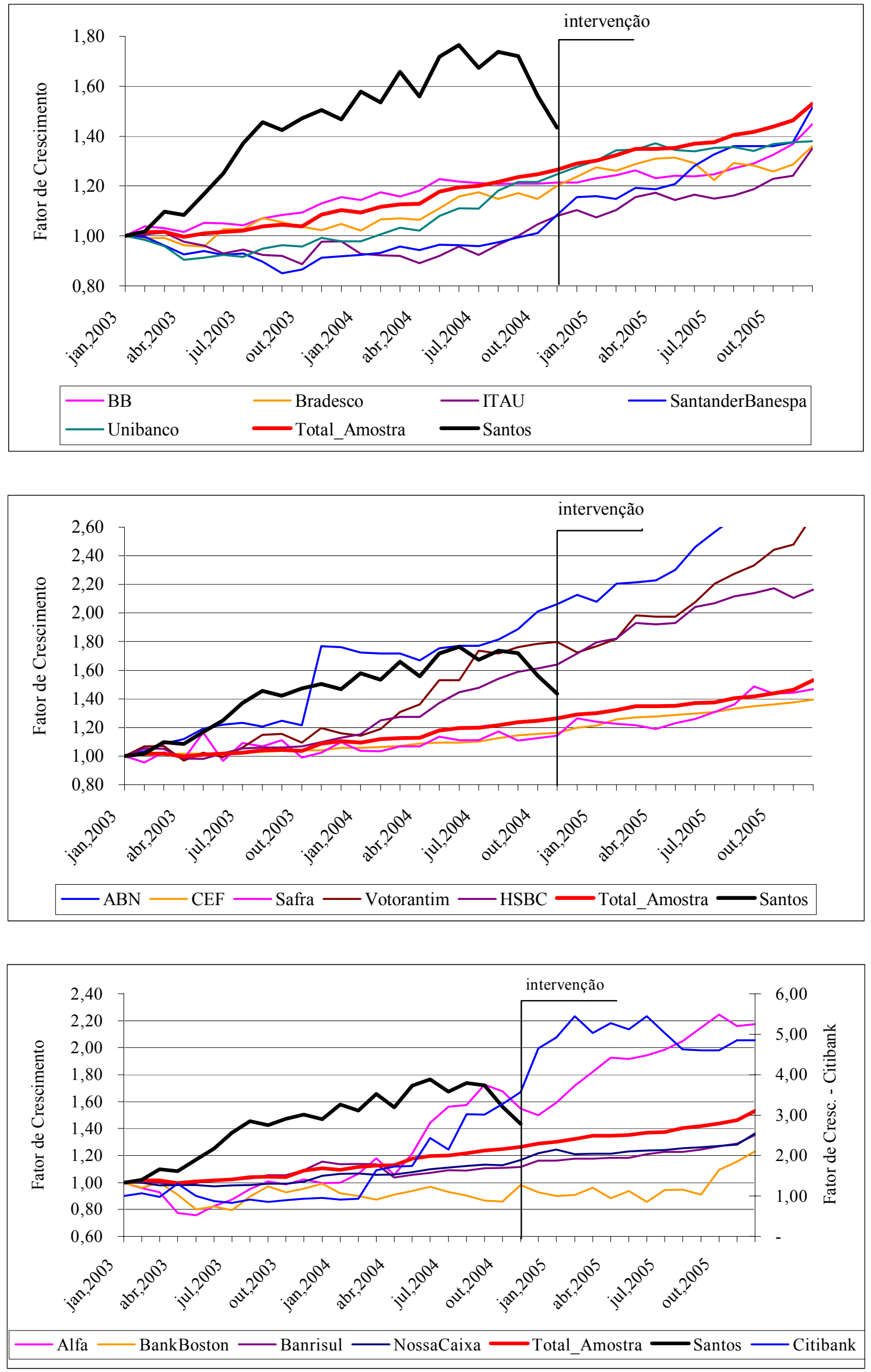

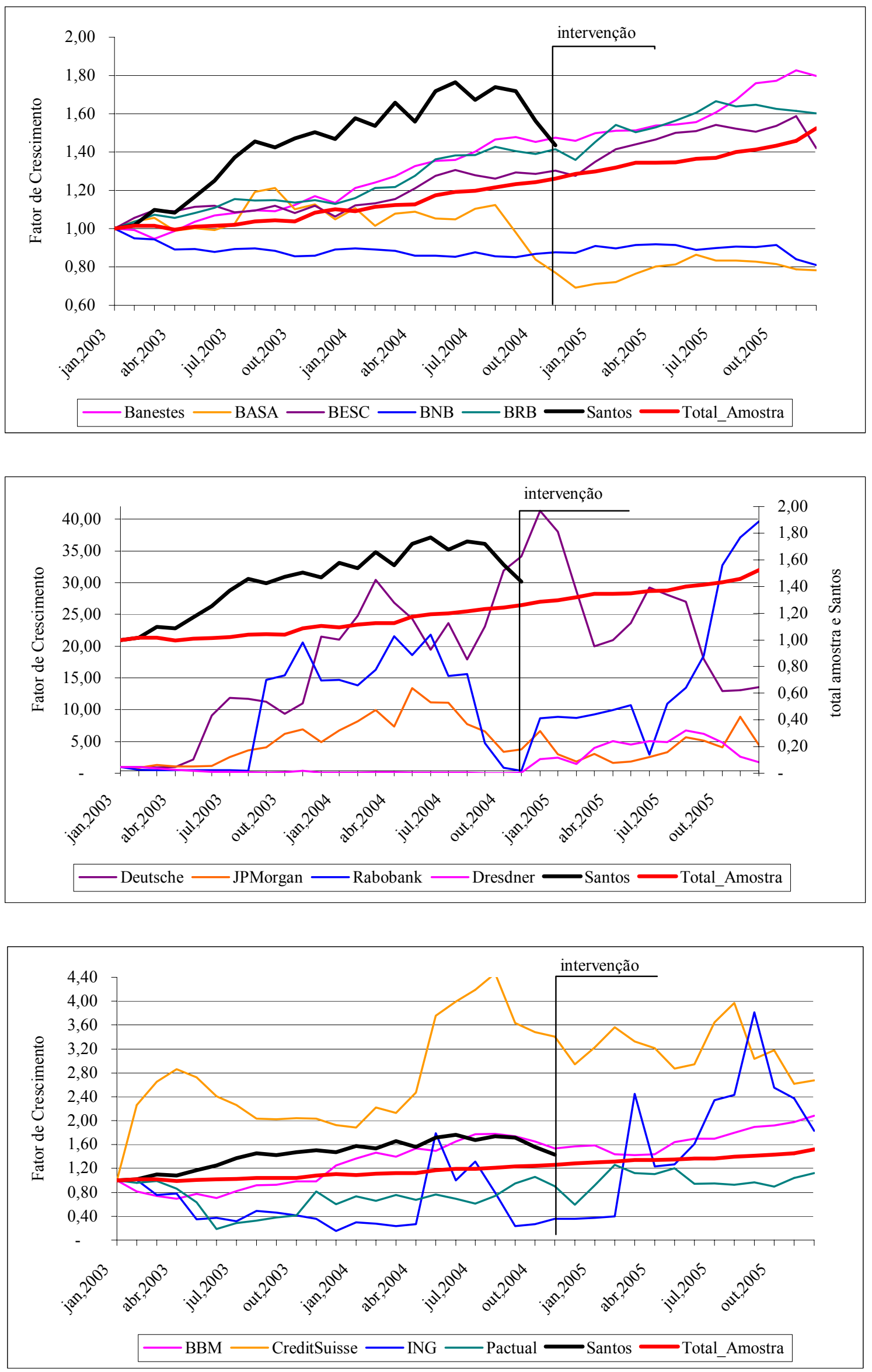

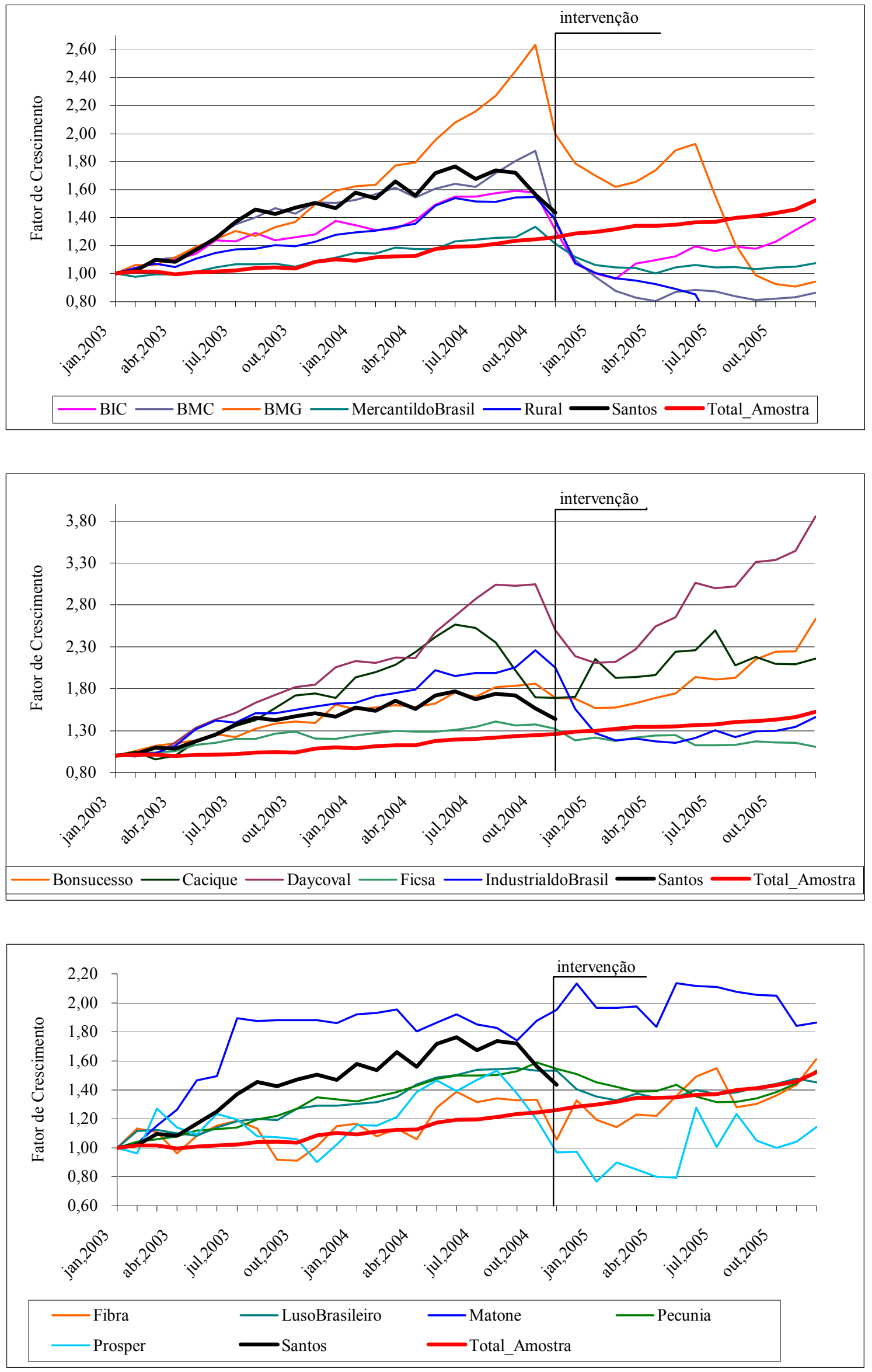

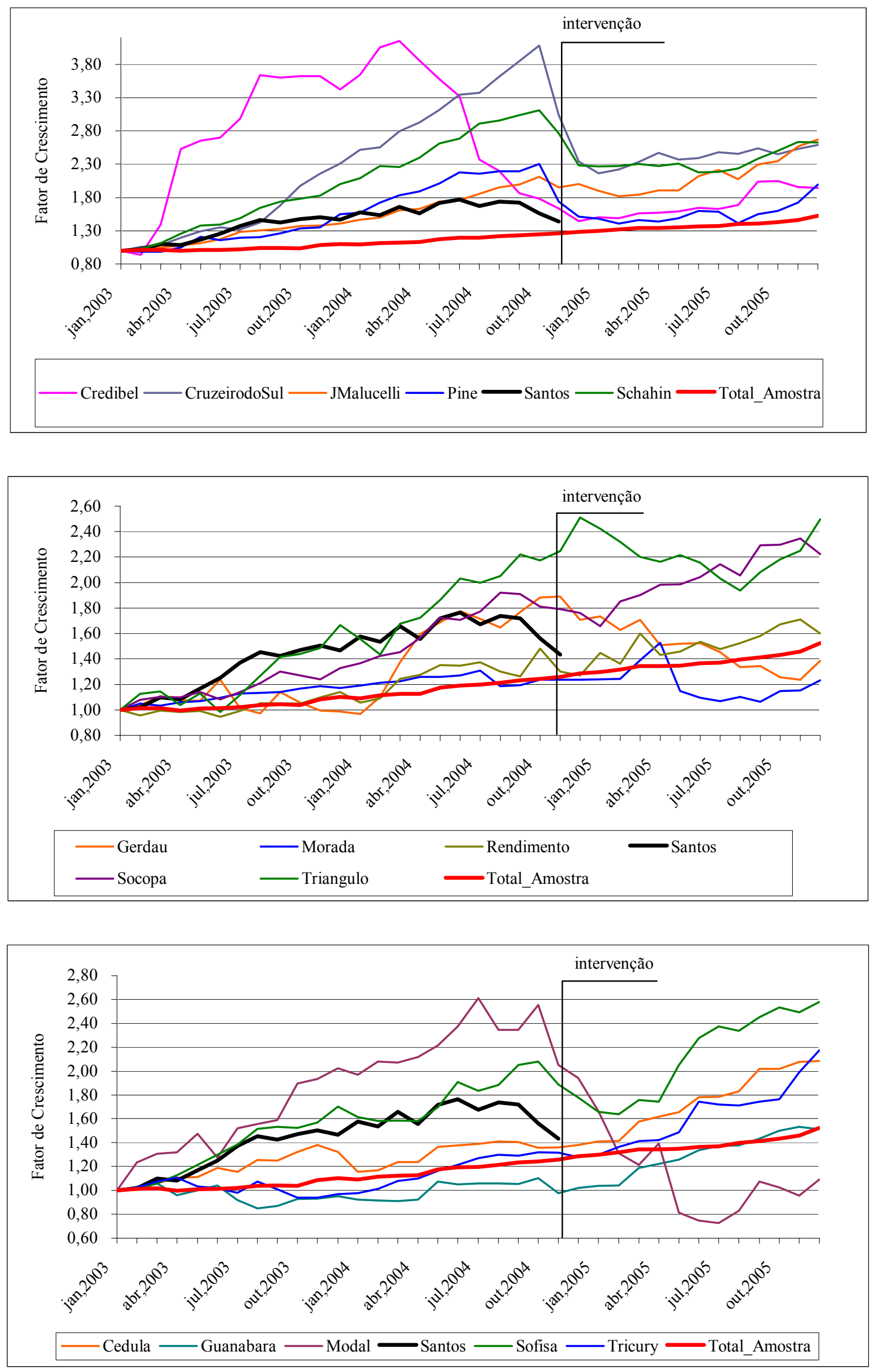

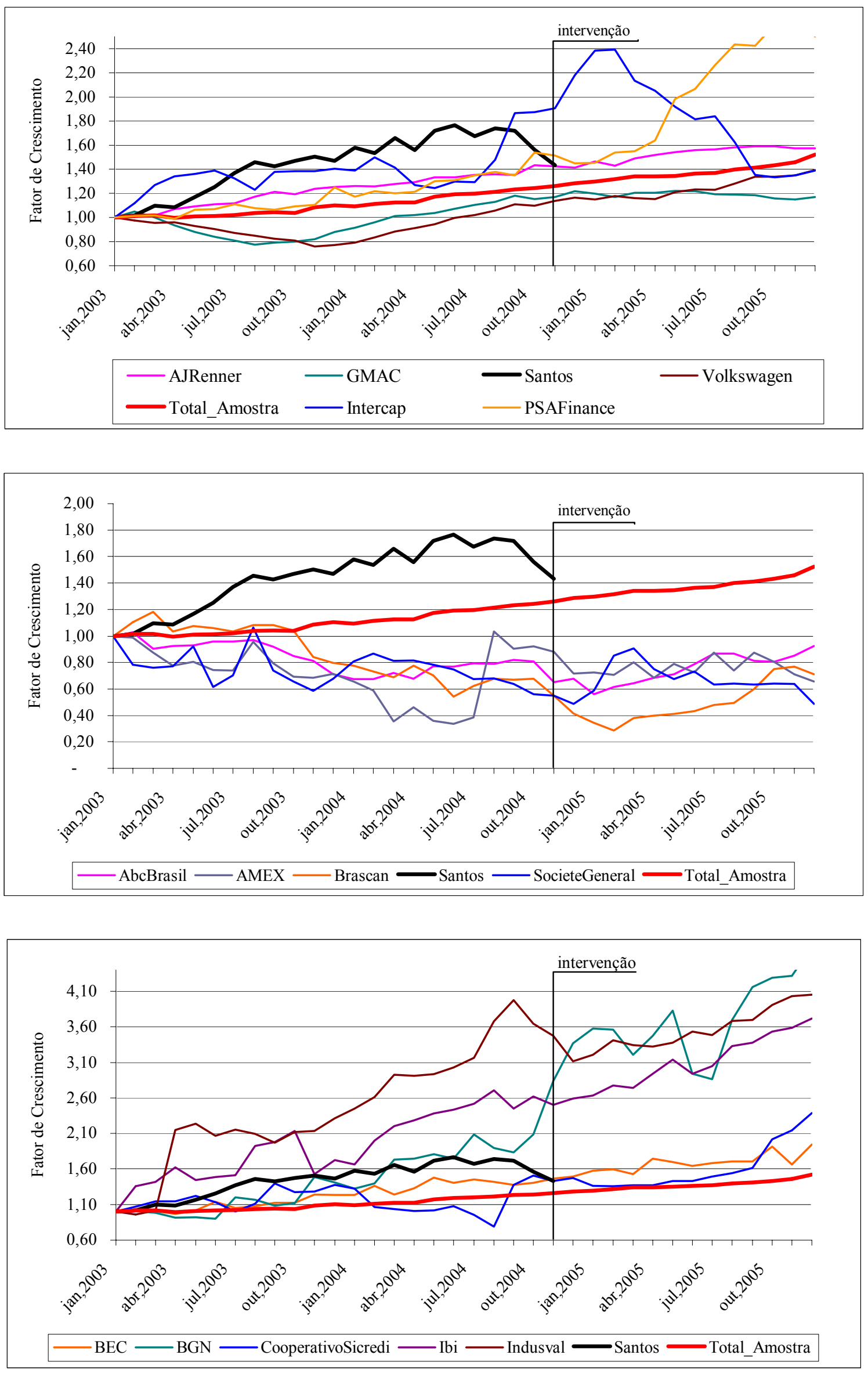

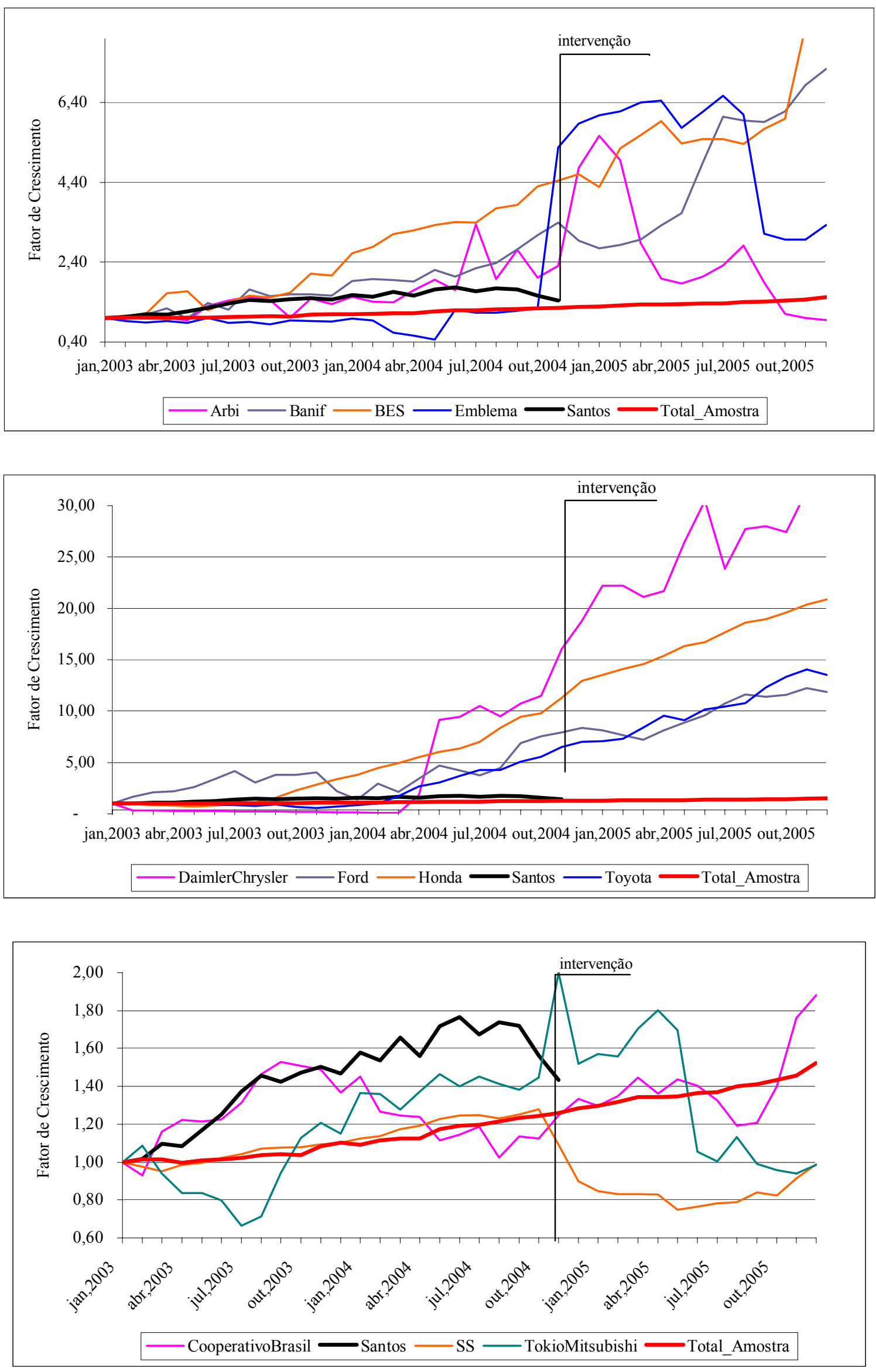


\section{APÊNDICE III}

Gráfico 1 - Alfa

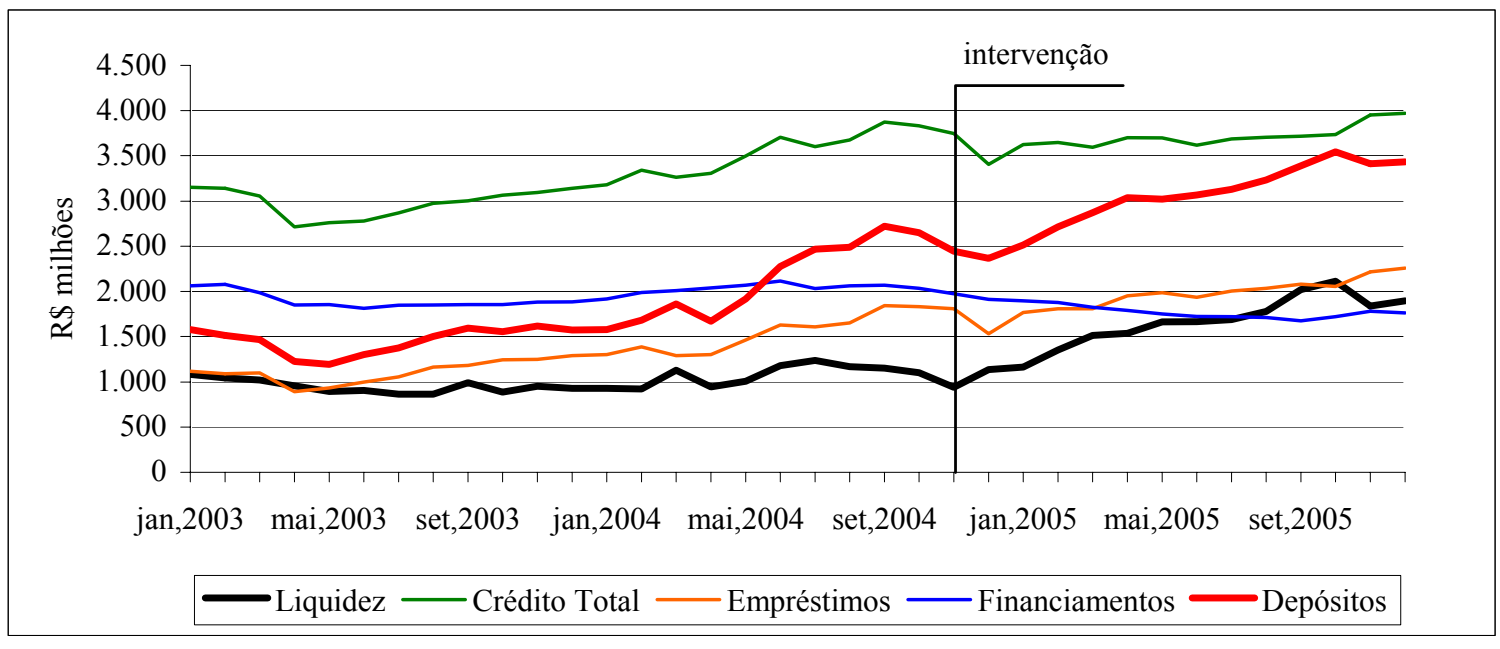

Gráfico 2 - BASA

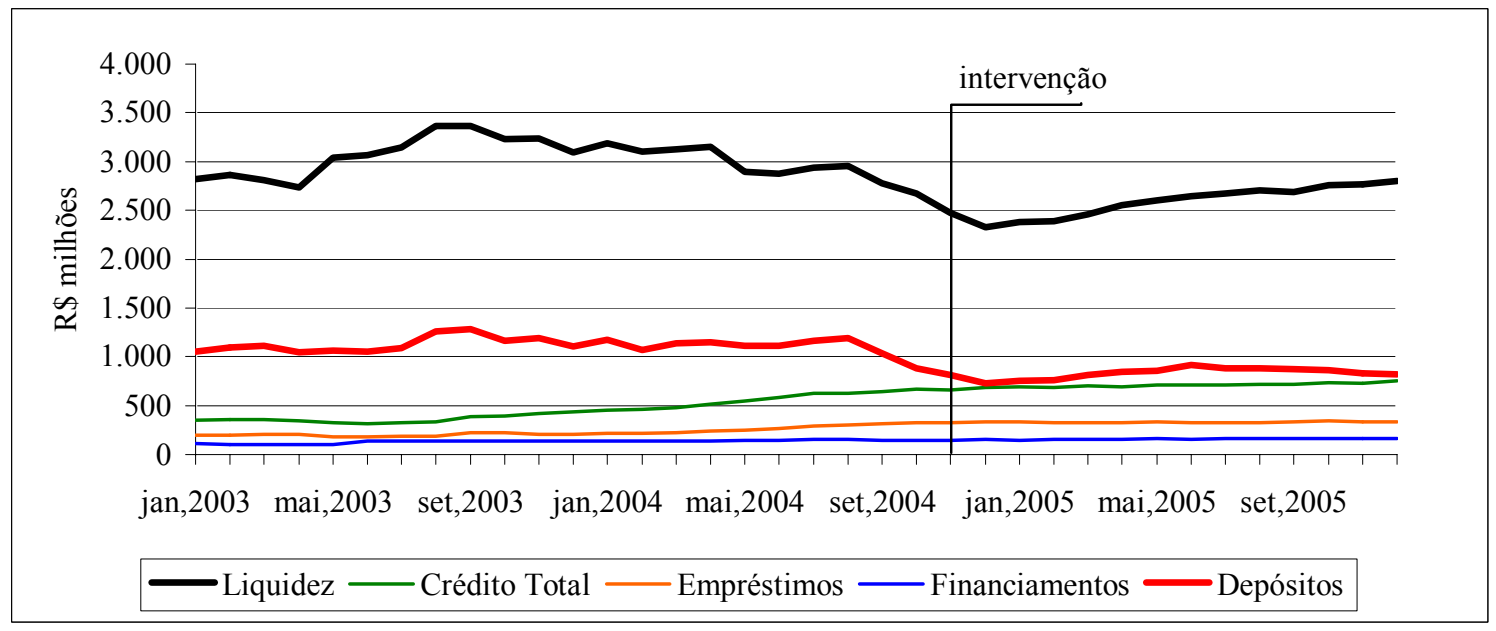

Gráfico 3 - BIC

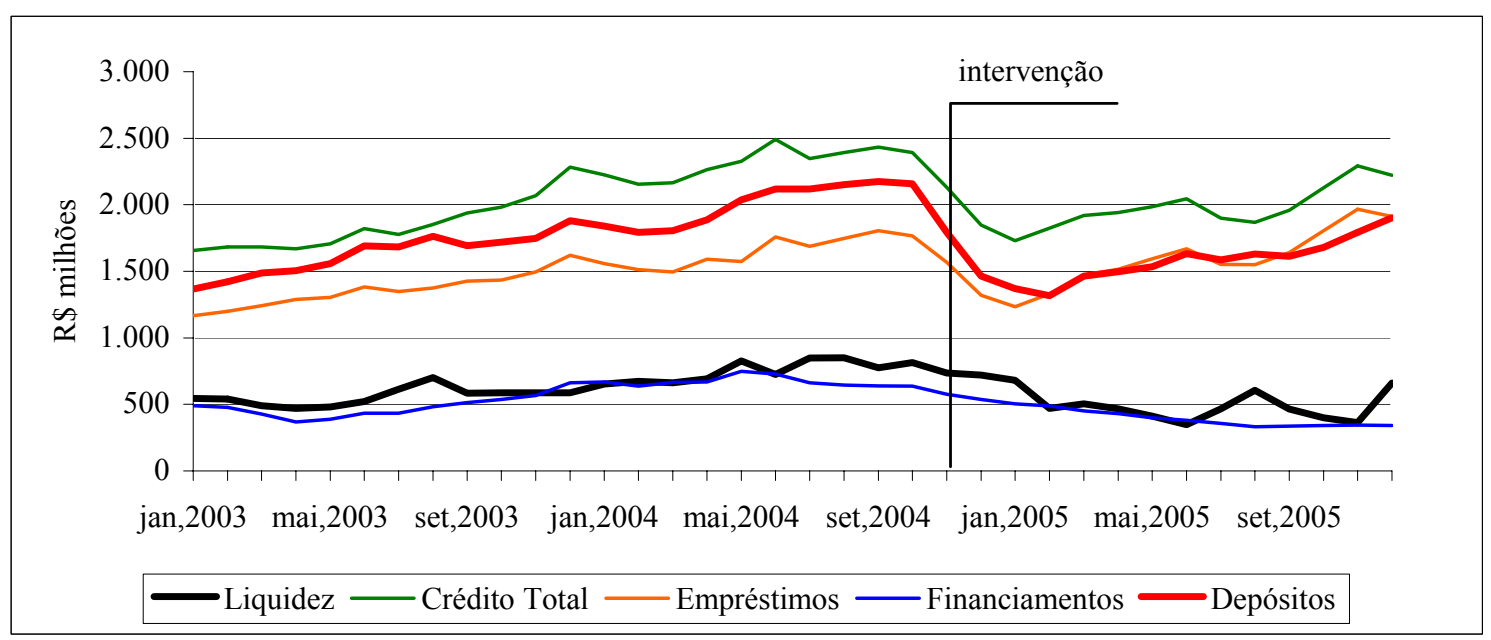


Gráfico 4 - BMC

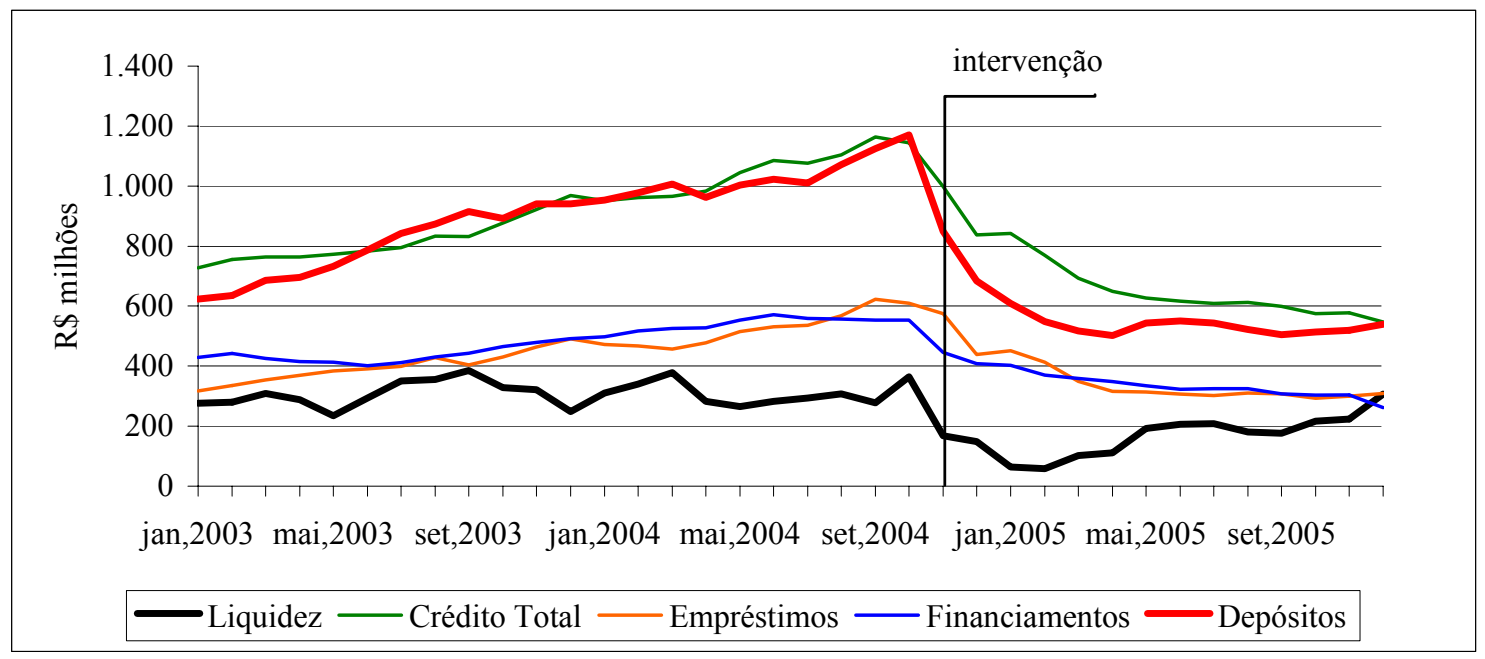

Gráfico 5 - BMG

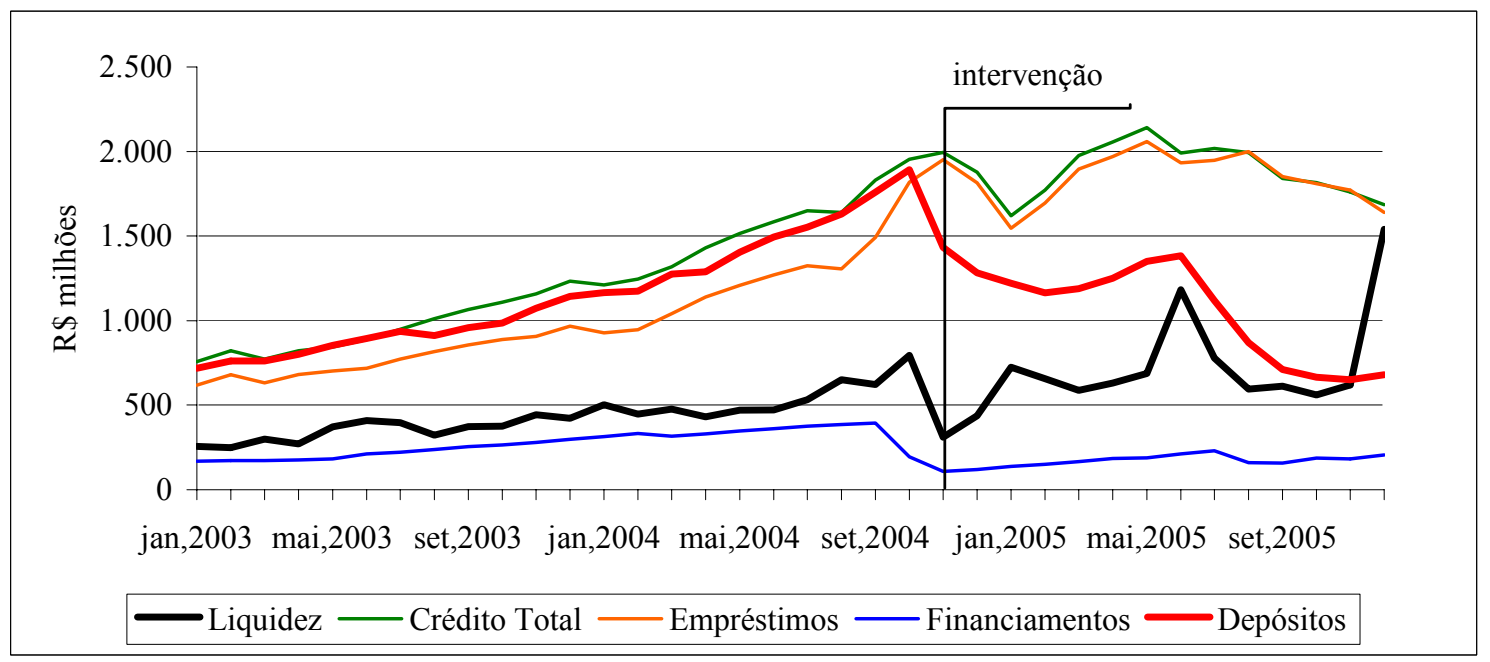

Gráfico 6 - Bonsucesso

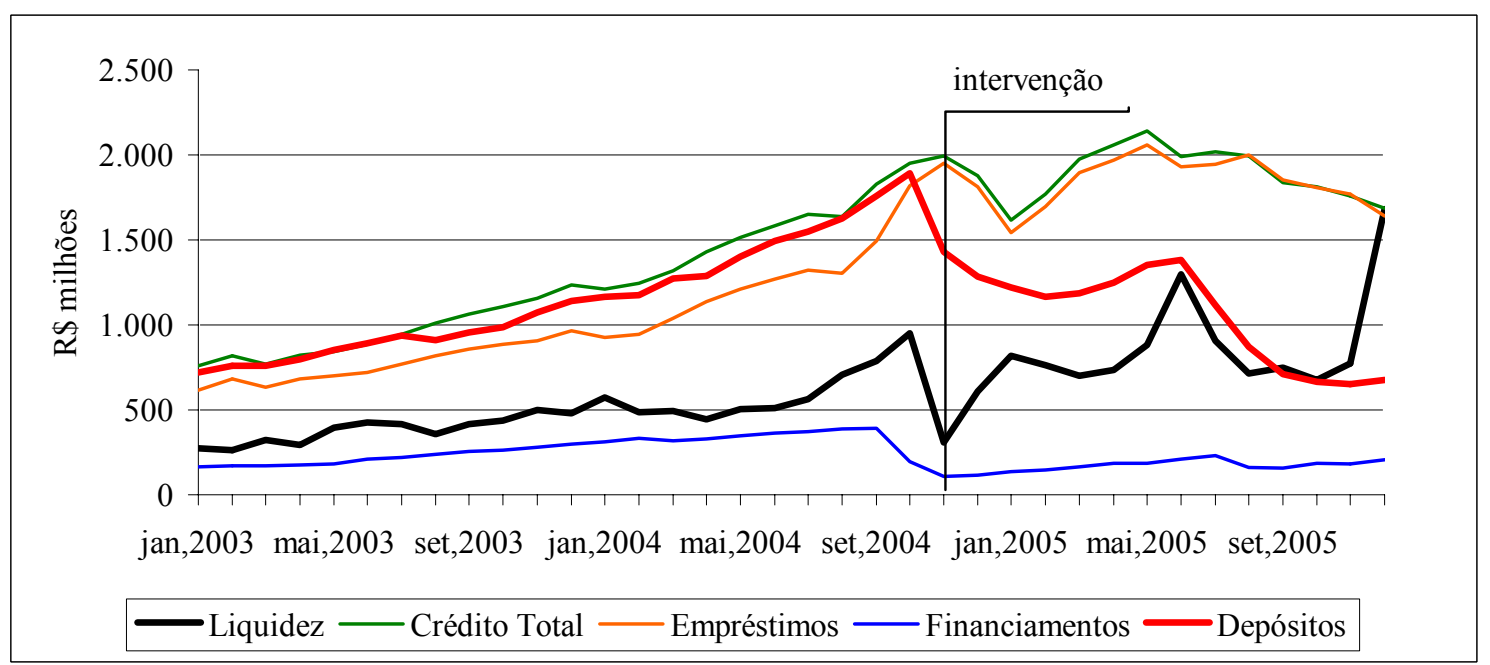


Gráfico 7 - Cruzeiro do Sul

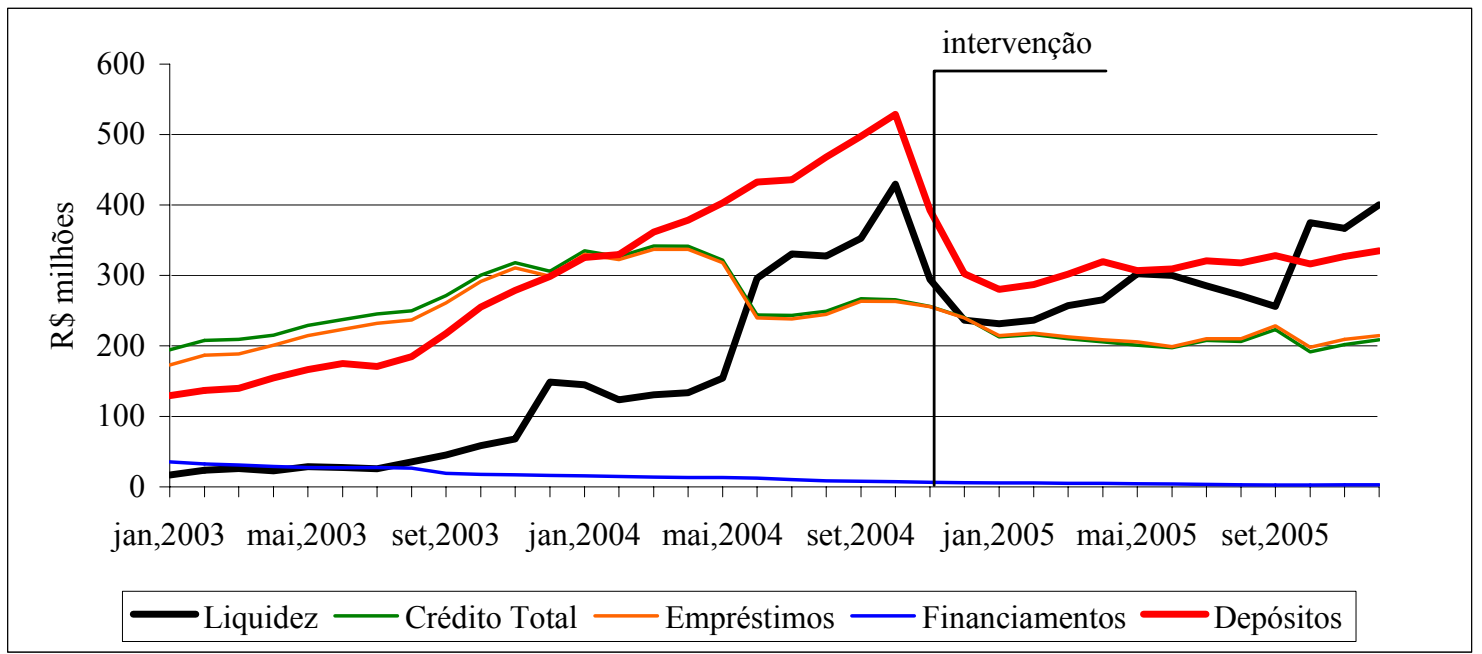

Gráfico 8 - Daycoval

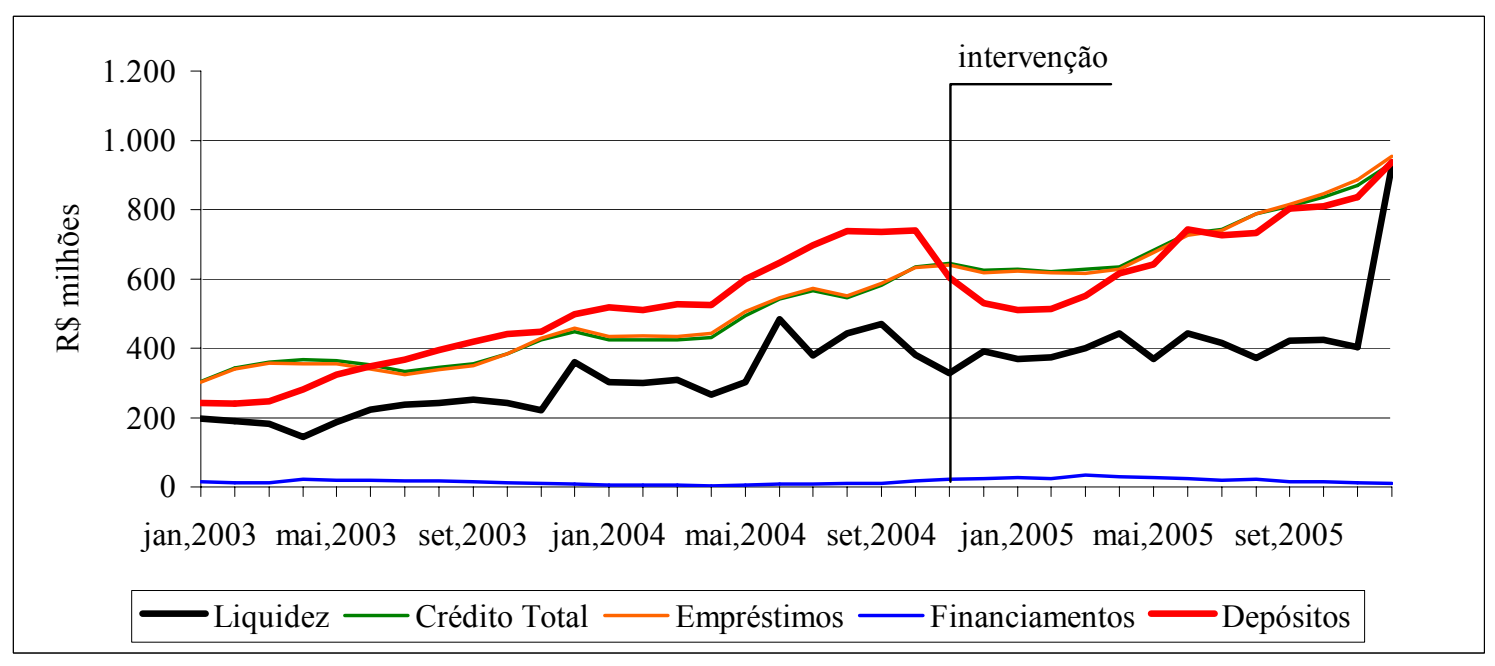

\section{Gráfico 9 - FICSA}

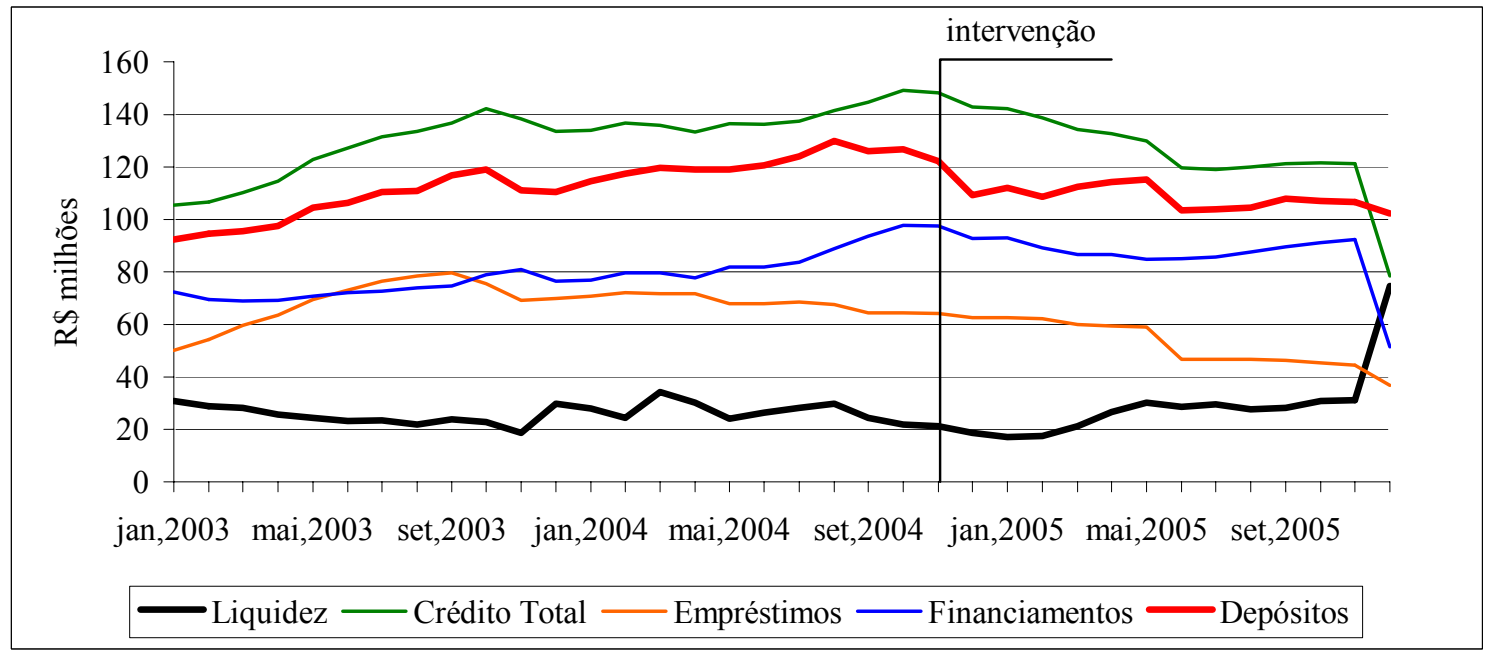


Gráfico 10 - Industrial do Brasil

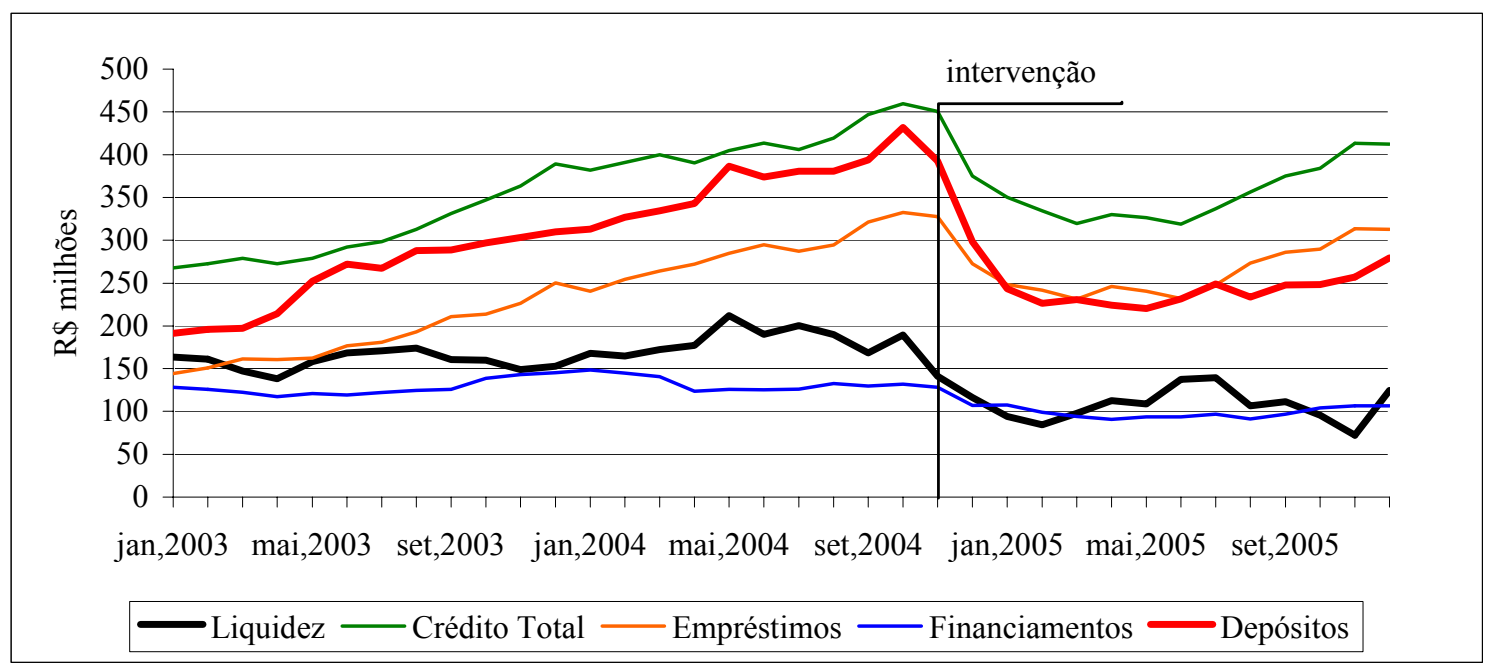

Gráfico 11 - Indusval

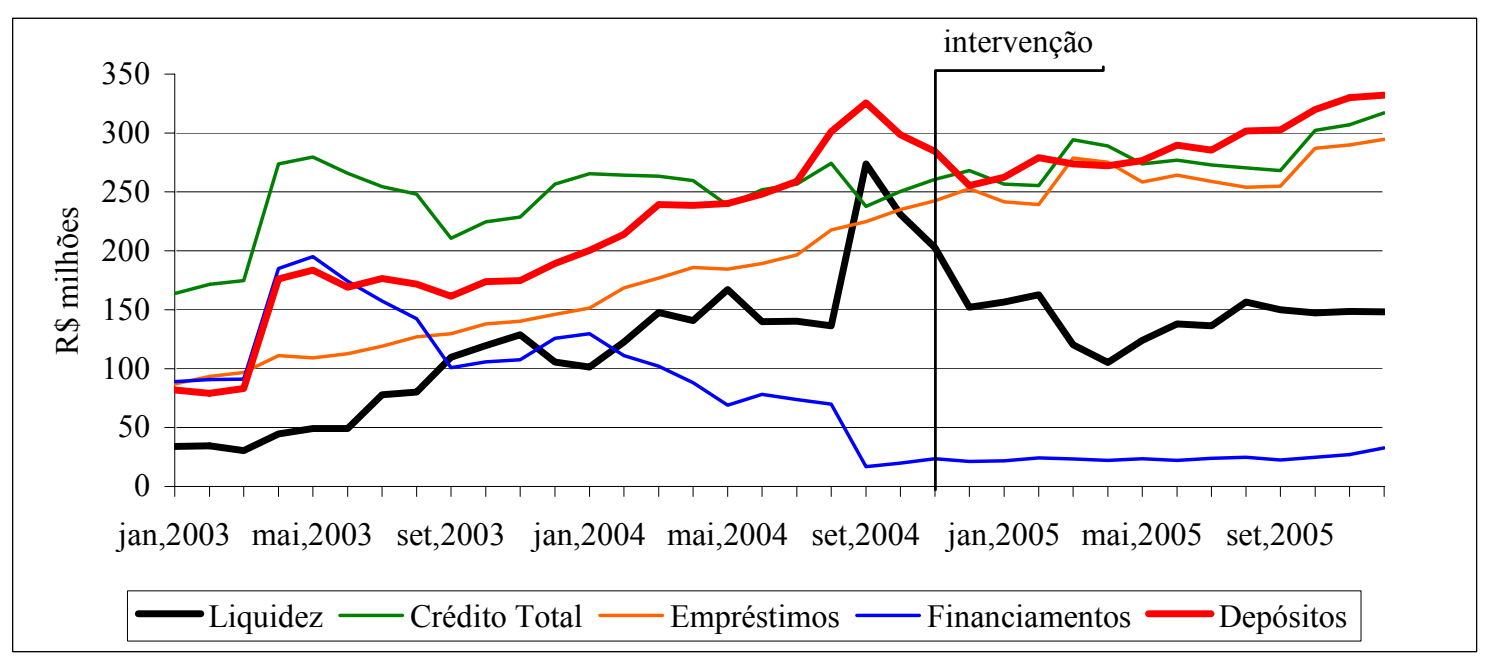

Gráfico 12 - JMalucelli

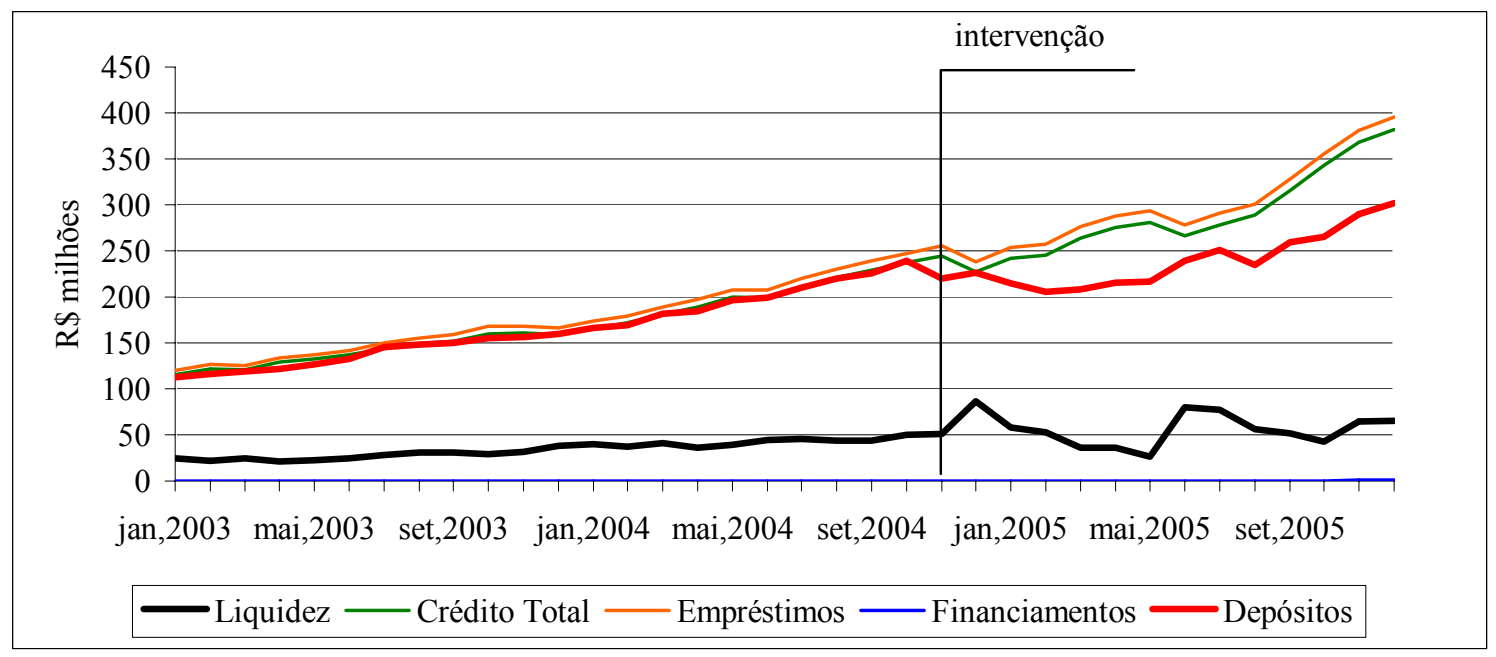


Gráfico 13 - Luso Brasileiro

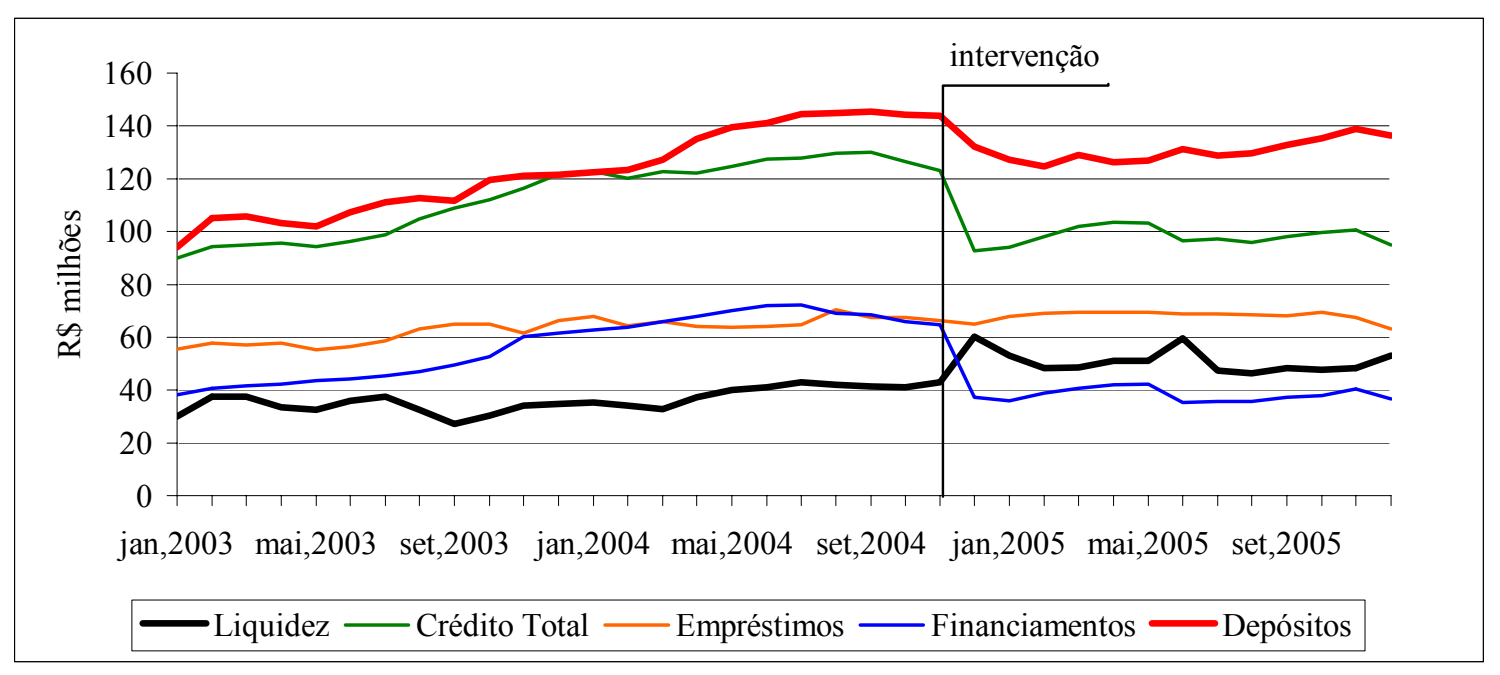

Gráfico 14 - Mercantil do Brasil

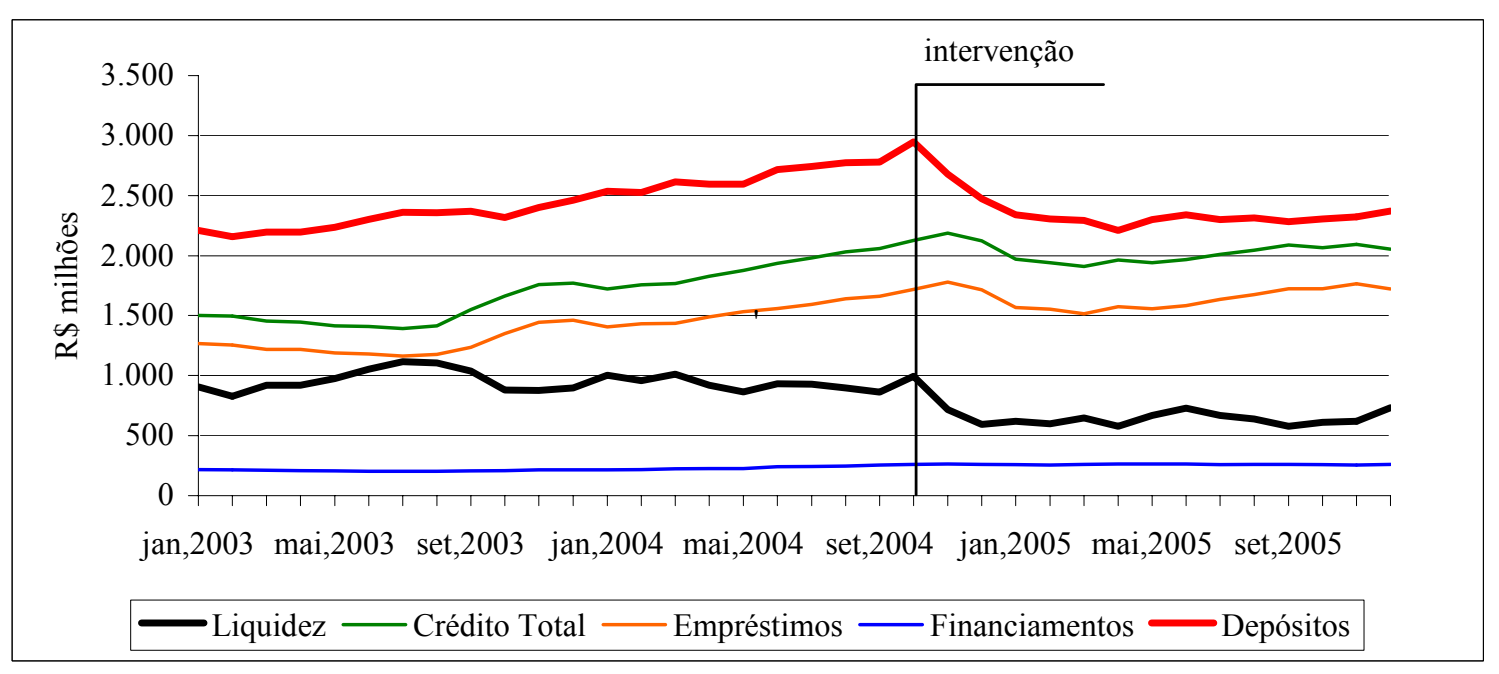

Gráfico 15 - Modal

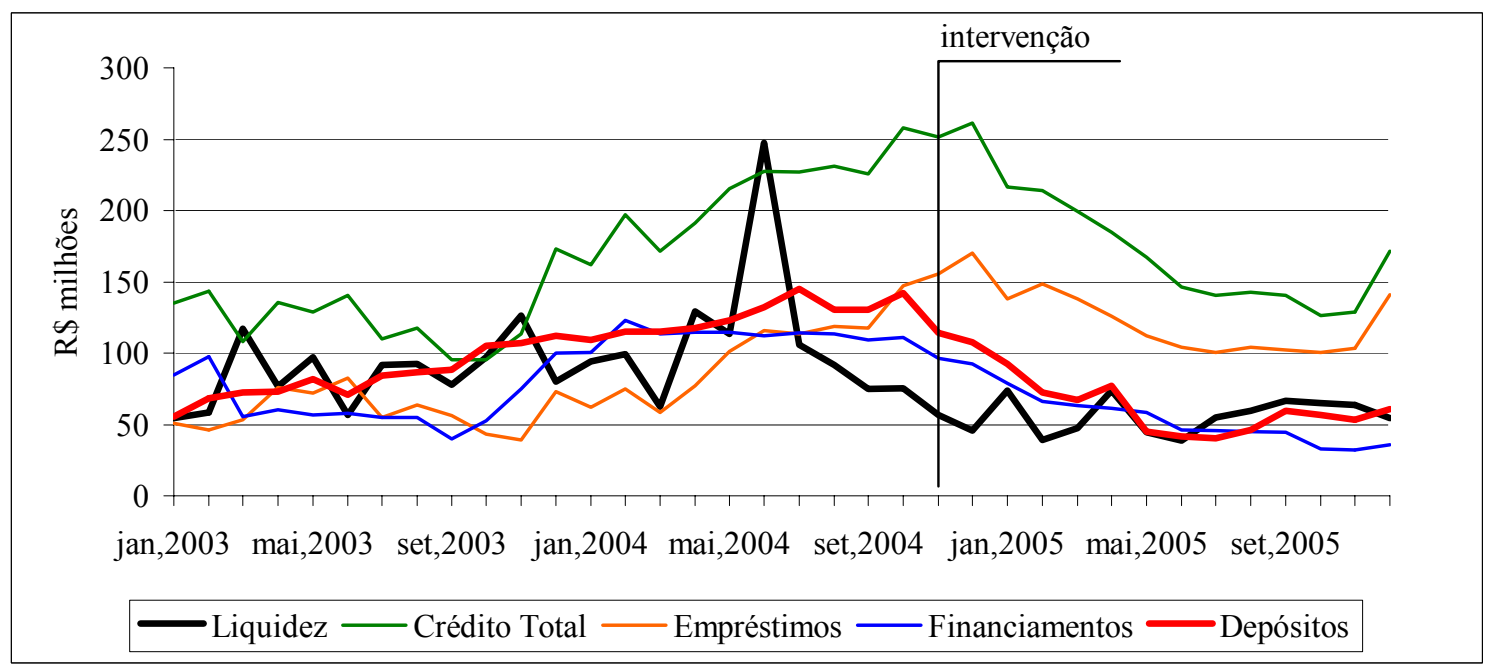


Gráfico 16 - Pecunia

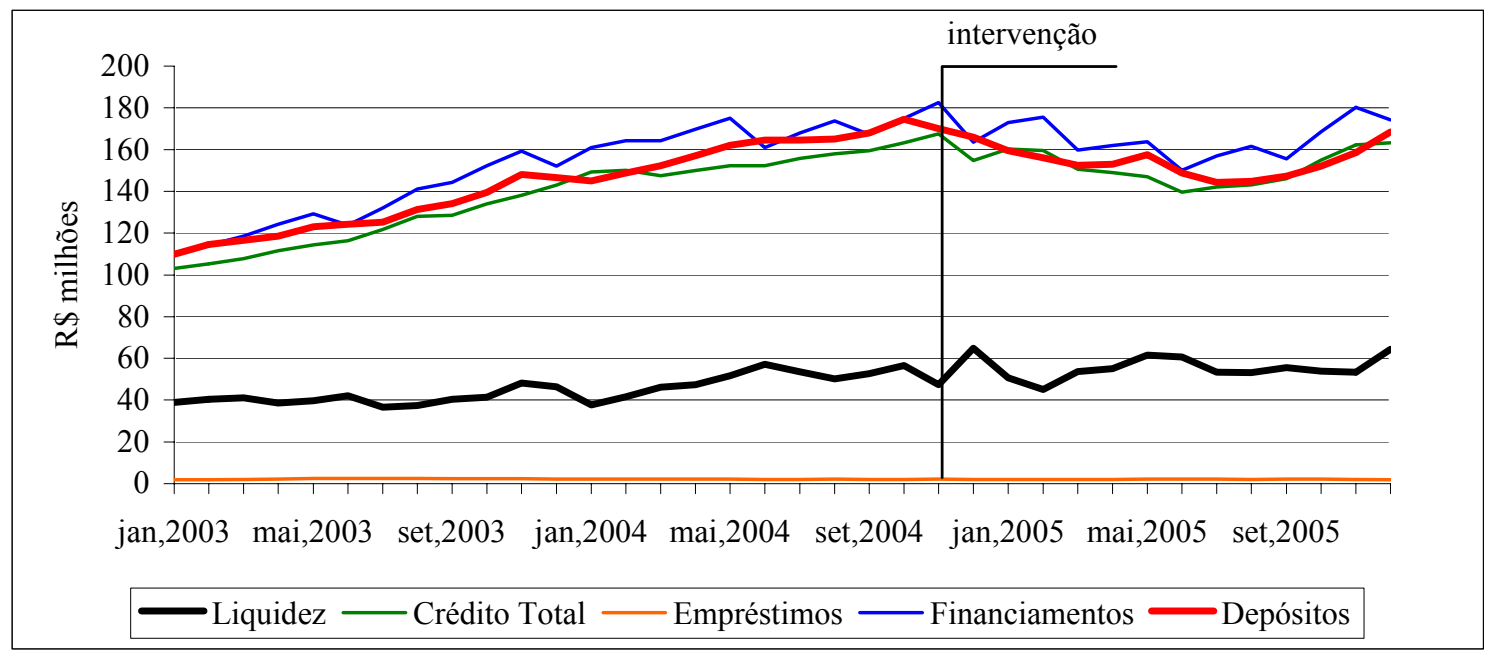

Gráfico 17 - Pine

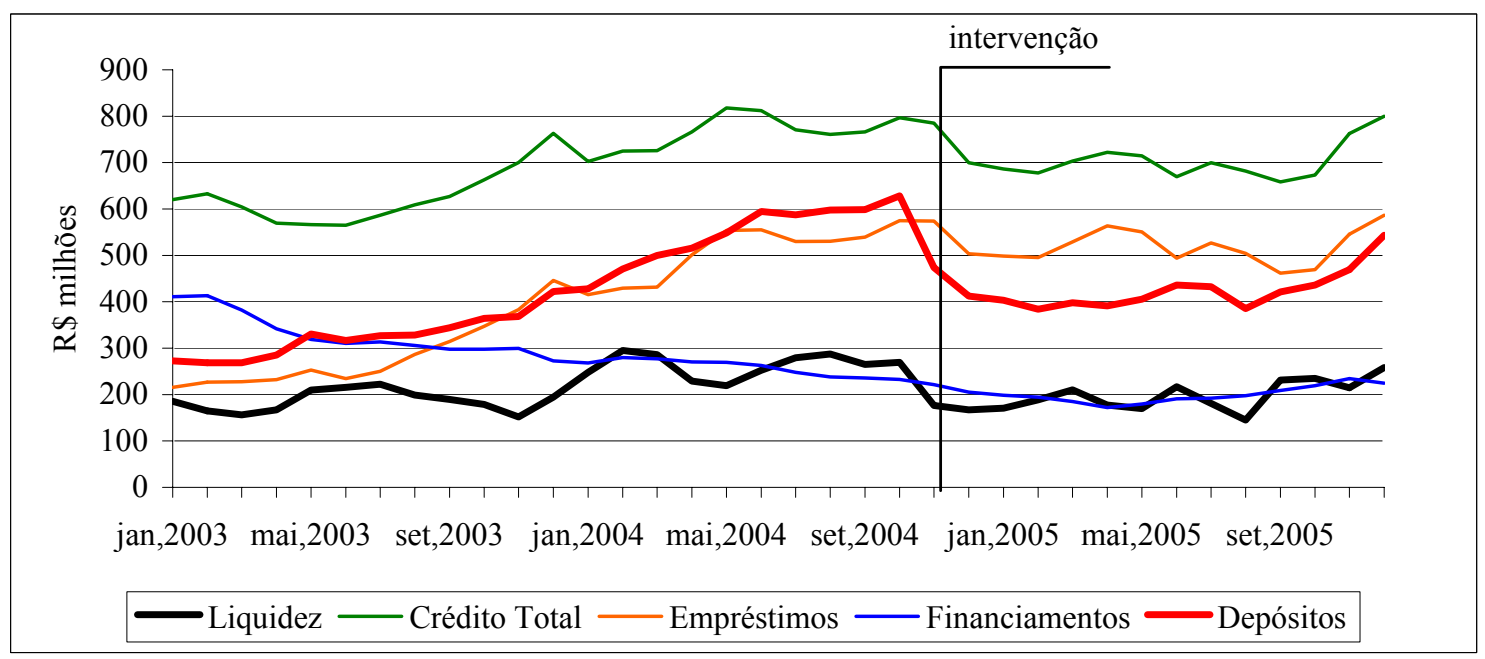

\section{Gráfico 18 - Prosper}

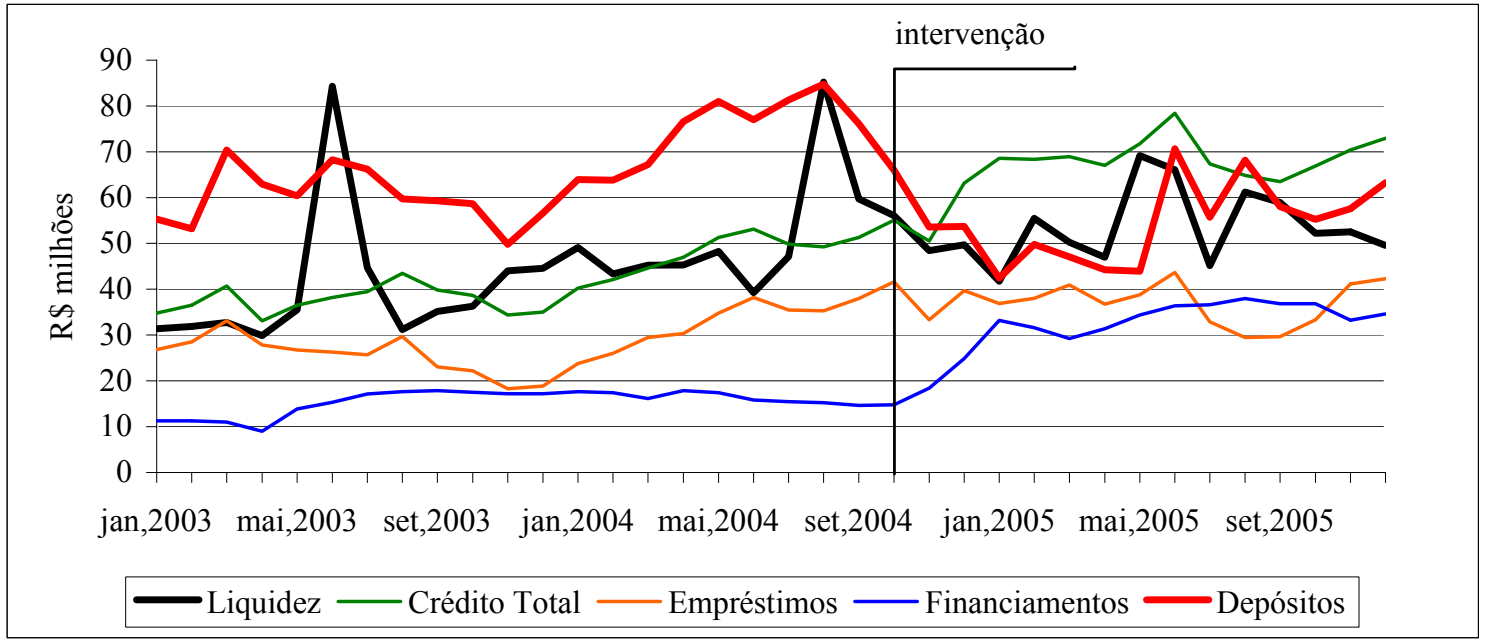


Gráfico 19 - Schahin

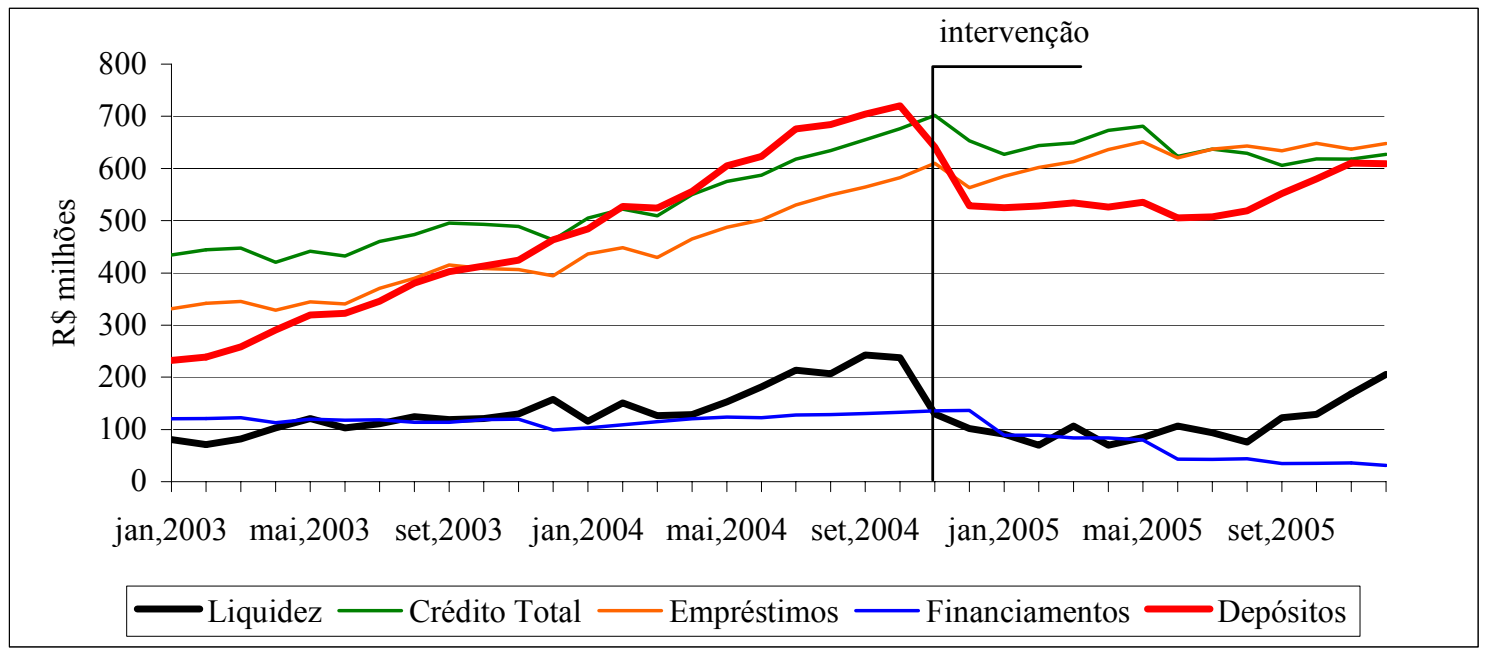

Gráfico 20 - Rural

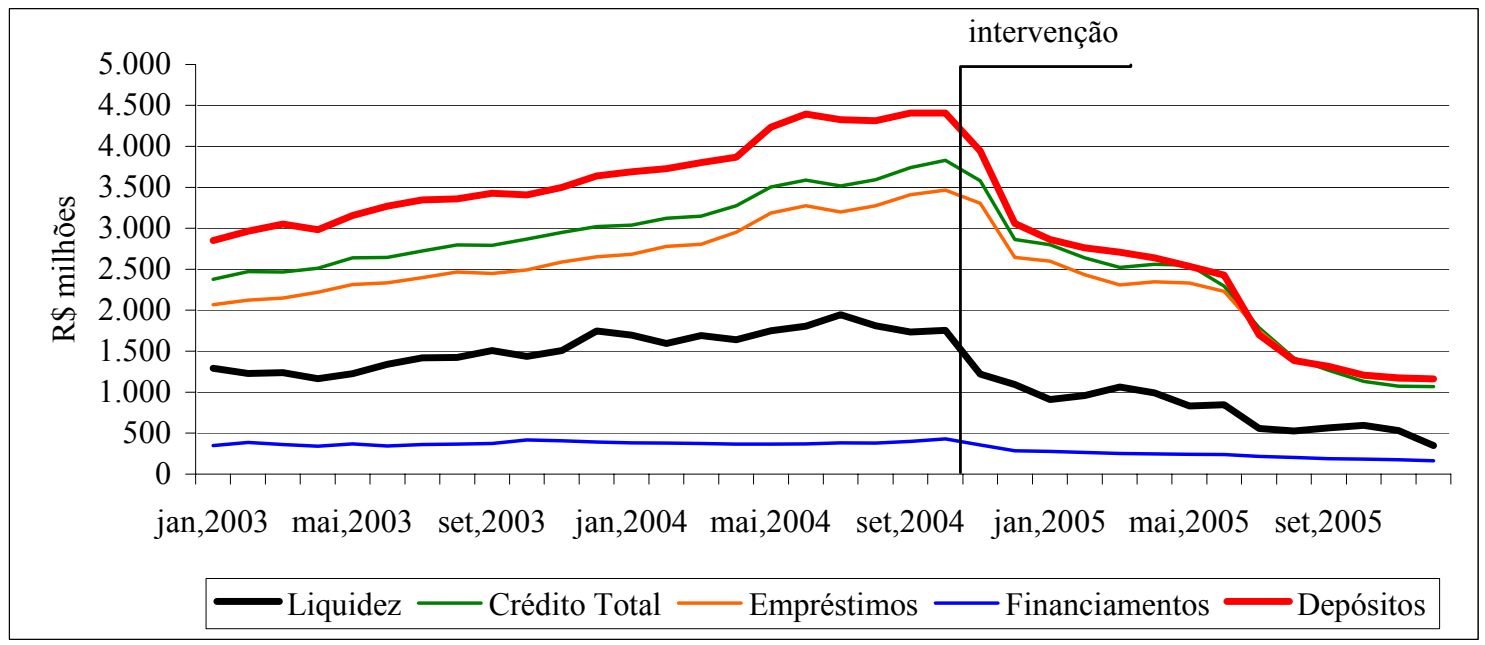

Gráfico 21 - Socopa

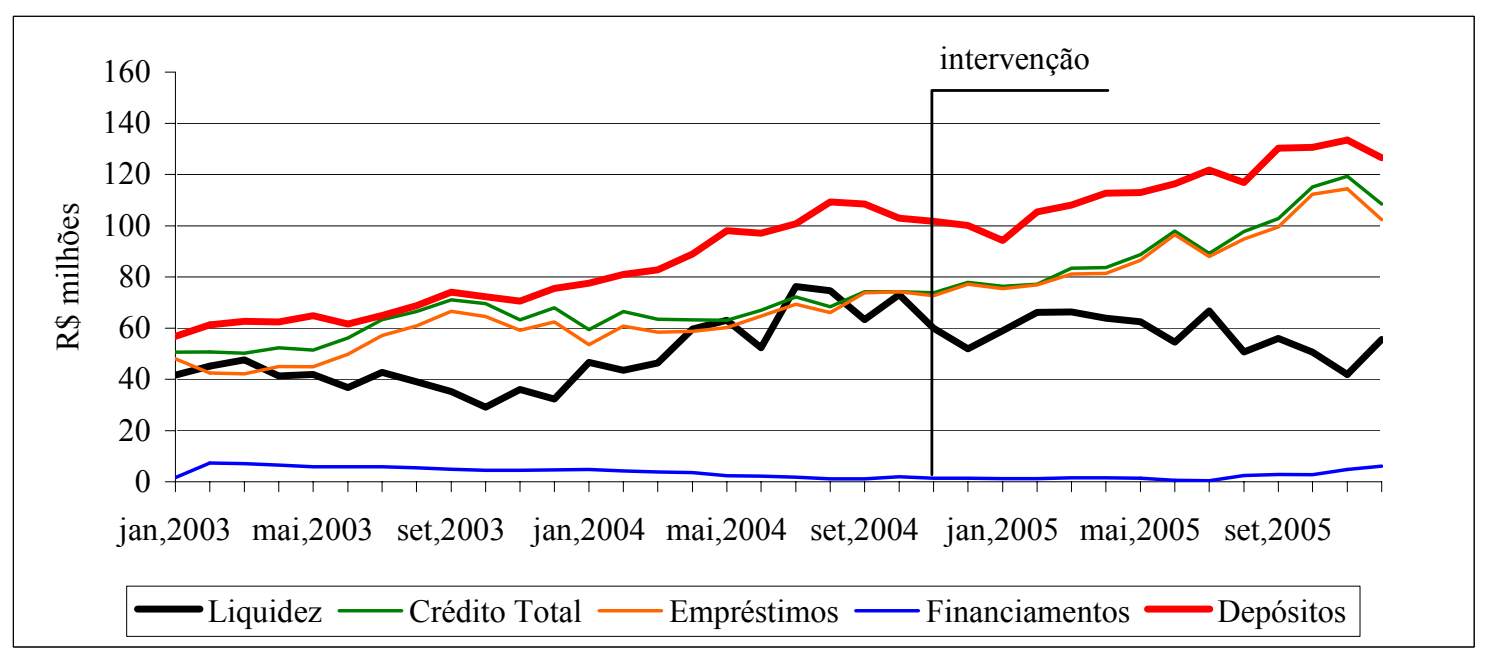


Gráfico 22 - Sofisa

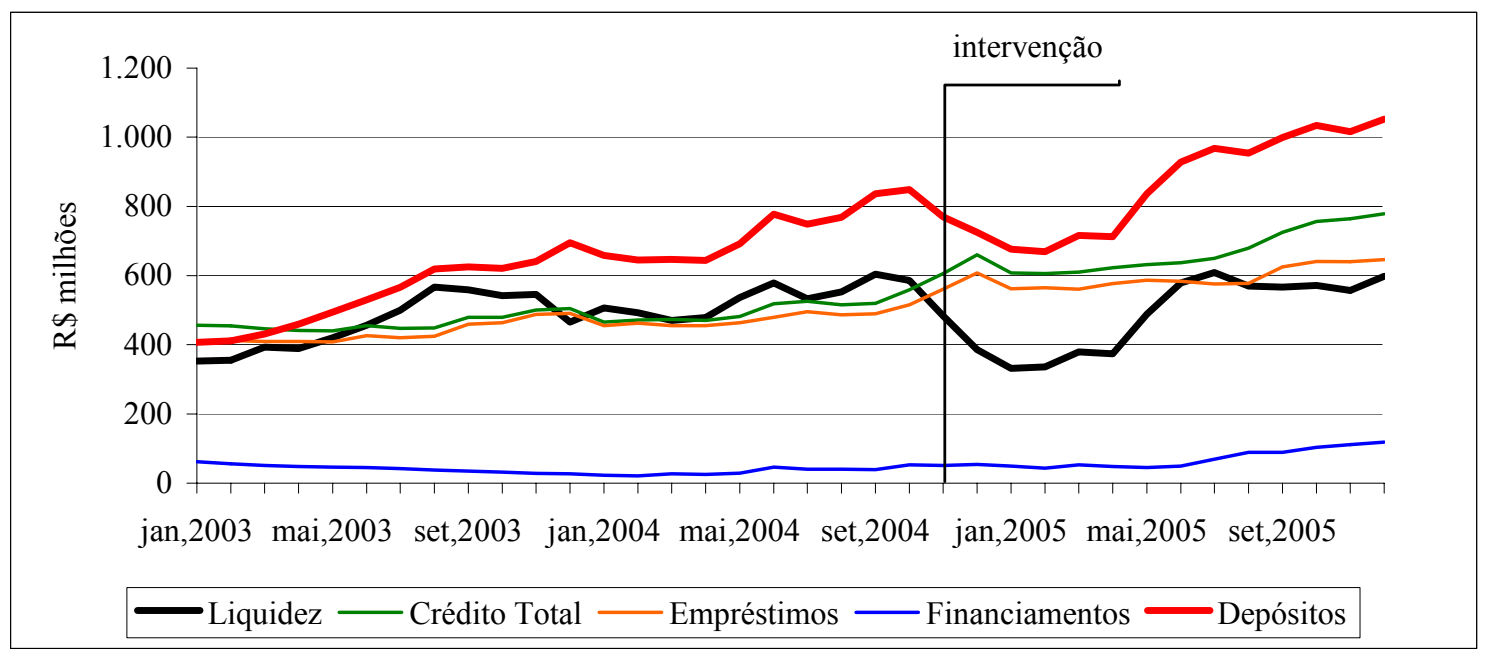

Gráfico 23 - Grupo Silvio Santos

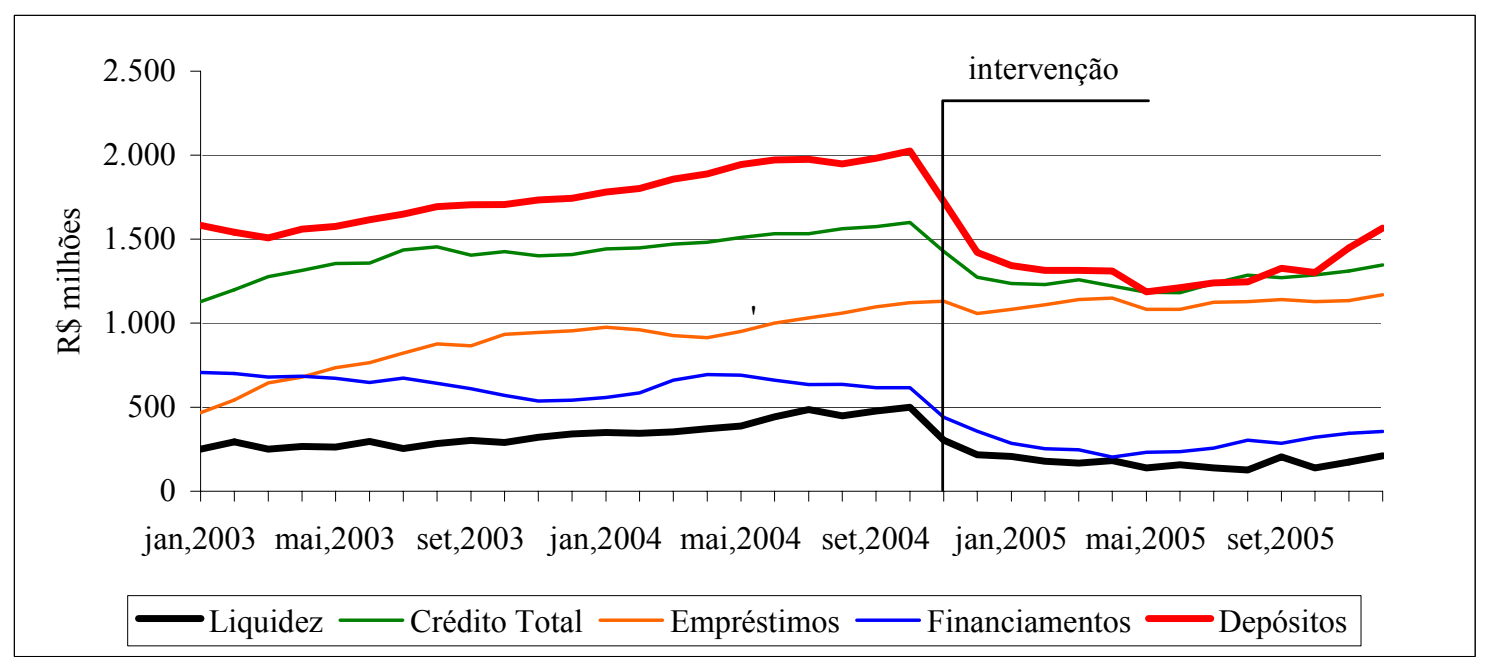

Gráfico 24 - Triângulo

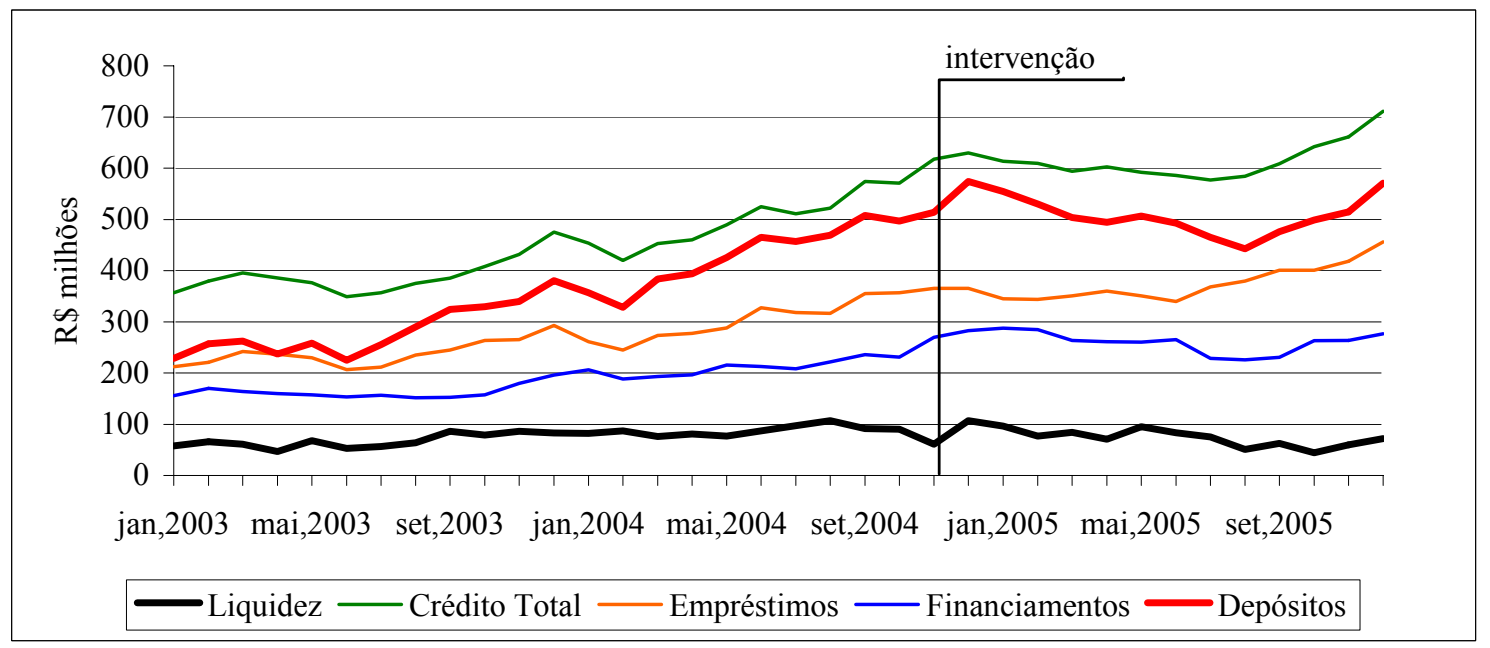




\section{APENDICE IV}

Data

Notícia

2.3.2001 Gestor do Banco Santos publica resultado de sete FIFs; (Investnews)

2.3.2001 Banco Santos lucra R\$51,4 milhões. (Investnews)

20.04.2001 Banco Santos recebe rating A- da consultoria Austin Asis (JB Online)

31.01.2002 Patrimônio do Banco Santos é o que mais cresce, diz pesquisa (INVERTIA)

5.2.2002 Lucro líquido do Banco Santos em 2001 atinge R\$ 60 milhões. (Investnews)

13.12.2002 Banco Santos planeja abrir o capital (Investnews)

15.09.2003 BB e Banco Santos lideram lista dos que mais receberam reclamações em agosto (Agência Brasil)

23.10.2003 Banco Santos diz que curva de juros mostrará se decisão foi correta (Investnews)

19.12.2003 Fitch reduz classificação do Banco Santos (Reuters Investor)

13.01.2004 Banco Santos diz que inflação deve convergir para meta (Investnews)

13.02.2004 Banco Santos inaugura família de fundos de commodities com boi (Reuters Investor)

25.03.2004 Ata do Copom mostra o que já era esperado, diz Banco Santos (Investnews)

15.04.2004 Banco Santos reavalia emissão de bônus de 1 ano (Reuters Investor)

22.04.2004 Banco Santos capta US\$ 25 mi e prevê nova emissão em julho (Reuters Investor)

24.9.2004 BC aprova aumento de capital e nova diretoria do Banco Santos (Investnews)

24.9.2004 Banco Santos prepara avanço entre pessoas físicas (Investnews)

12.11.2004 Banco Central determina intervenção no Banco Santos (INVERTIA)

13.11.2004 Dificuldades financeiras obrigam BC a intervir no Banco Santos (Reuters Investor)

13.11.2004 Banco Santos precisa fazer aporte de R\$ 700 milhões (INVERTIA)

13.11.2004 Advogado diz que boatos causaram problema no Banco

16.11.2004 BC repassa reais ao mercado e ameniza temor com Banco Santos (Reuters Investor)

18.11.2004 Banco Santos tem no mercado repasses de R\$950 mi do BNDES (Reuters Investor)

18.11.2004 Fundo da CEF tem prejuízo por impacto do Banco Santos (Reuters Investor)

19.11.2004 Dólar opera em queda, atento a informações sobre o Banco Santos ( INVERTIA)

19.11.2004 BC muda regra de compulsórios para amenizar prejuízos com Banco Santos (Investnews)

19.11.2004 Mercado revê risco de pequenas instituições após Banco Santos (Reuters Investor)

23.11.2004 Fitch alerta para risco de Banco Santos contaminar sistema

(Reuters Investor) 
23.11.2004 Banco Santos pode prejudicar instituições de pequeno porte (Reuters Investor)

24.11.2004 BC abre inquérito para investigar o Banco Santos (INVERTIA)

24.11.2004 BNDES diz que devedores do Banco Santos são bons pagadores (Reuters Investor)

24.11.2004 Para encerrar intervenção, Banco Santos está à venda (Reuters Investor)

25.11.2004 Funcionários públicos têm R\$ 300 milhões no Banco Santos (INVERTIA)

26.11.2004 Dono do Banco Santos tem empresas que valem R\$ 1,5 bilhão (INVERTIA)

29.11.2004 Banco Santos descartava agências de risco que o avaliavam mal (Investnews)

30.11.2004 Transação liga Banco Santos a fraudador da previdência (INVERTIA)

15.12.2004 Desempregada é presidente de empresa do dono do Banco Santos (INVERTIA)

29.12.2004 Banco Santos propõe moratória para evitar liquidação (Reuters Investor)

29.3.2005 BNDES abre sindicância para investigar Banco Santos (Reuters Investor)

4.5.2005 BC decreta liquidação extrajudicial do Banco Santos (Reuters)

6.5.2005 Cotistas do Banco Santos ainda não sabem o tamanho do prejuízo (Gazeta Mercantil)

2.6.2005 BC antecipa pedido de falência do Banco Santos (INVERTIA)

13.6.2005 Caso Banco Santos prejudicou Mercantil, diz Fitch (Investnews)

21.10.2005 Falência do Banco Santos deve confirmar calote (Jornal Valor Econômico) 